\title{
FINANCING THE HIGHWAY NEEDS OF INDIANA.
}

\section{FEBRUARY 1969 - NUMBER 6}

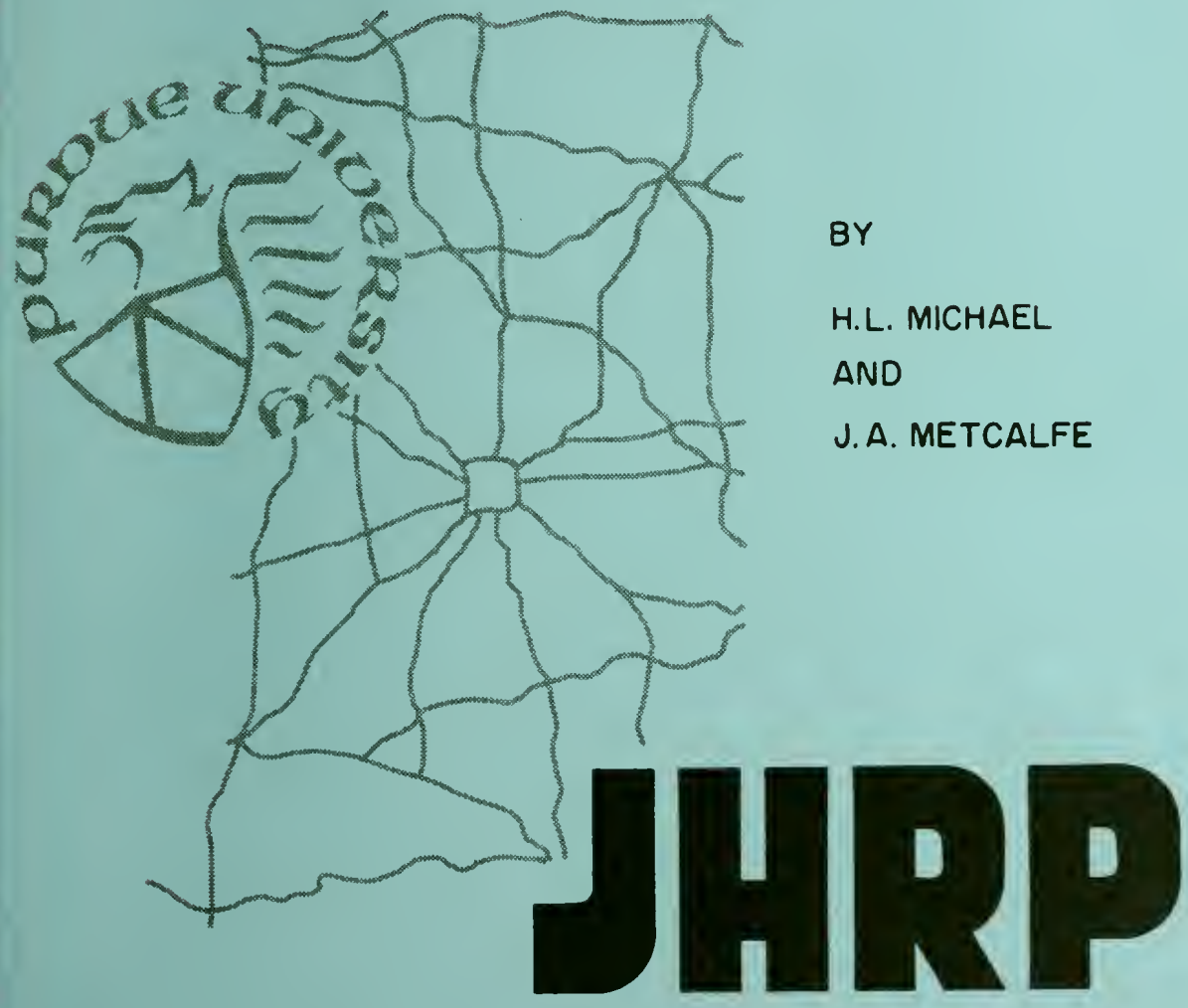

JOINT HIGHWAY RESEARCH PROJECT PURDUE UNIVERSITY AND

INDIANA STATE - HIGHWAY COMMISSION 

FINANCING THE HIGHWAY NEEDS OF INDIANA

To: J. F. McLaughlin, Director

Joint Highway Research Project

From: H. L. Michael, Associate Director Joint Highway Research Project
February 14, 1969

File No: $3-4-3$

Project No: $\mathrm{C}-36-73 \mathrm{C}$

The Indiana State Legislative Committee to Review Findings of the Highway Needs Study requested in late 1967 that the Joint Highway Research Project conduct studies on sources of revenue, distribution formulas, cost responsibility and bonding for use by the committee. A proposal to the Project Advisory Board for such studies was approved in December 1967. During the period December 1967 - July 1968, Professor H. L. Michael and Graduate Assistant J. A. Metcalfe conducted numerous studies on the items requested by the Legislative Committee and met with the Committee many times to present and discuss their findings.

Many of these studies have since July 1968 been extended and organized into a report. A copy of this report is attached. It is titled "Financing the Highway Needs of Indiana" and authored by Messr. Michael and Metcalfe. The report includes factual information on possible sources of revenue for additional financing as well as current practices and levels of financing by Indiana and other states. It also includes a brief discussion of the theories of highway finance, a discussion and case study of bond financing for highways, an analysis of the distribution of highway funds to the several units of government responsible for highway construction and a comparison of the several highway improvement programs available to Indiana at this time.

The report is one of information and includes findings but does not make recommendations. Copies of the report have been made available to the Legislative Committee members and to the current members of the Roads Comittee of the Senate and House. 
Digitized by the Internet Archive in 2011 with funding from

LYRASIS members and Sloan Foundation; Indiana Department of Transportation 
The report is presented to the Board for information and for the record. The research studies authorized by the Board for the Legislative Committee are complete with the submission of this report.

Respectfully submitted,

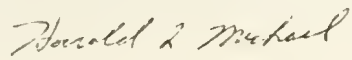

Harold I. Michael

Associate Director

HII $: m z$
cc: F. L. Ashbaucher
W. I. Dolch
W. H. Goetz
W. L. Grecco
G. K. Hallock
M. E. Harr

R. H. Harrell

C. F. Scholer

J. A. Havers

M. B. Scott

V. E. Harvey

W. T. Spencer

G. A. Leonards

H. R. J. Walsh

F. B. Mendenhall

K. B. Woods

R. D. Miles

E. J. Yoder 
FINANCING THE HIGHWAY NEEDS OF INDIANA

by

Harold L. Michael

Associate Director

and

James A. Metcalfe

Graduate Assistant

Joint Highway Research Project

$$
\begin{gathered}
\text { Project: } c-36-73 \mathrm{C} \\
\text { File: } 3-4-3
\end{gathered}
$$

Purdue University

Lafayet $t e$, Indiana

February 14, 1969 
LIST OF TABLES.......................... vi

LIST OF FIGURES ..................... ix

ABSTRACT ..........................

CHAPTER I. INTRODUCTION................. I

Indiana Highways..................... I

CHAPTER II. THEORY OF HIGHWAY FINANCE........... 7

Investment Decision....................... 7

Needs Studies....................... 8

Economic Analysis..................... 10

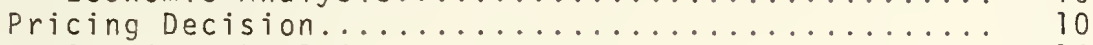

Setting the Price...................... 14

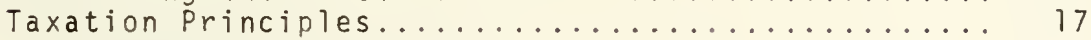

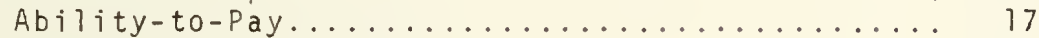

Benefits Principle................... 18

Socio-Economic Principle................. 19

Benefit Principle Governs................ 19

Taxation Objectives....................... 19

Equity.............................. 21

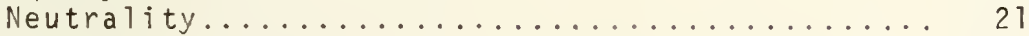

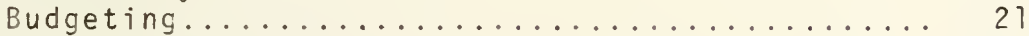

Cost Allocation Between User and Non-User Groups... 22

Added Expenditure Method................. 22

Relative Use and Predominant Use Methods....... 23

Earnings - Credit Method................ 23

A Theoretical Approach................ 24

Cost Allocation Among User Groups............ 28

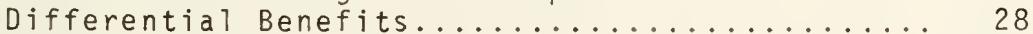

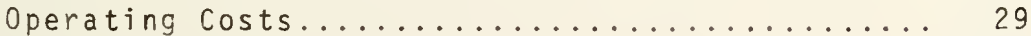

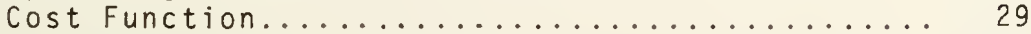

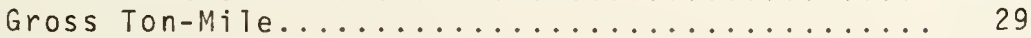

Incremental cost.................... 30 


\section{TABLE OF CONTENTS (continued)}

Problems of Financial Administration of Highways...

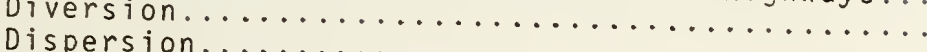

32

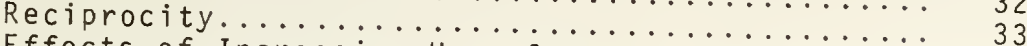

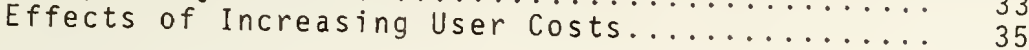

CHAPTER III. HIGHWAY TAXATION IN INDIANA.......... 37

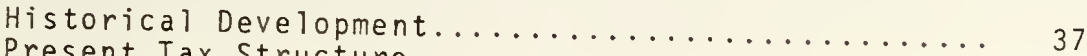

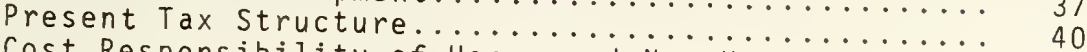

Cost Responsibility of Users and Non-Users............ 48

CHAPTER IV. REVENUE SOURCES FOR HIGHWAYS.......... 52

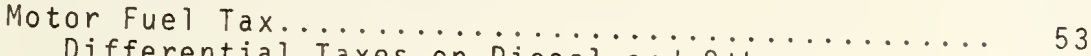

Differential Taxes on Diesel and 0 ther

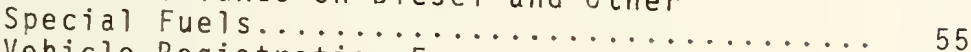

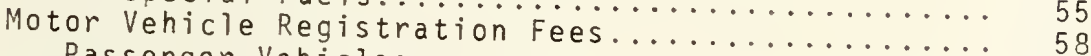

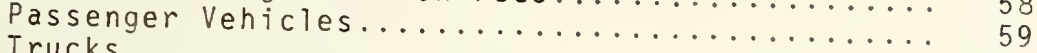

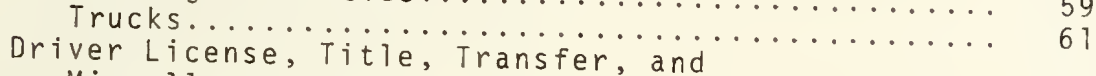

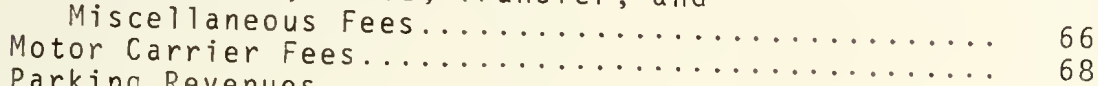

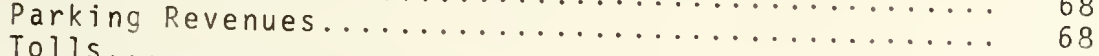

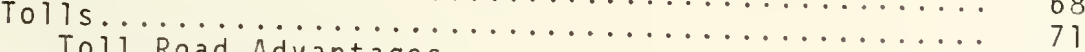

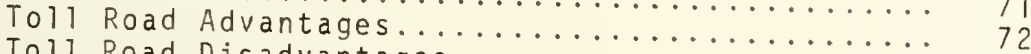

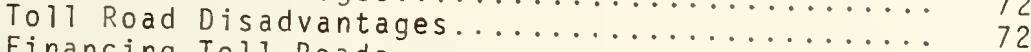

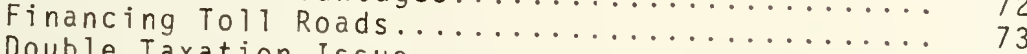

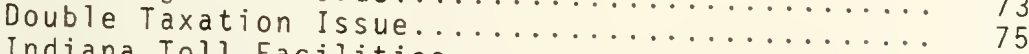

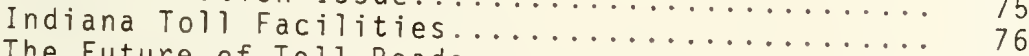

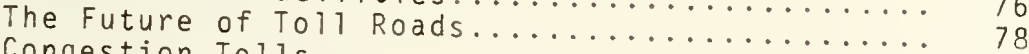

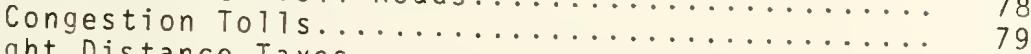

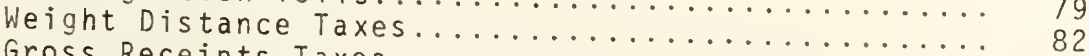

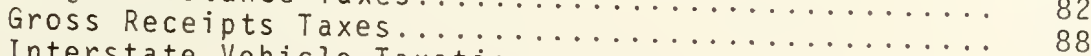

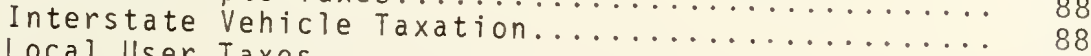

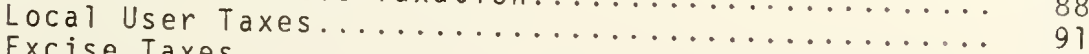

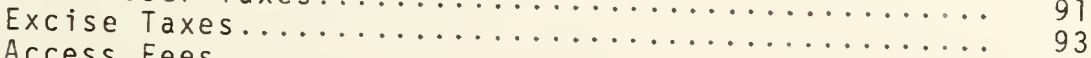

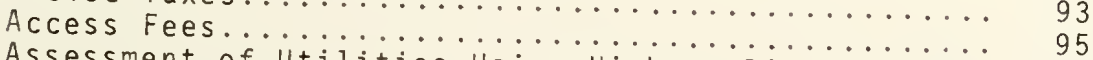

Assessment of Utijities Using Highway Right of Way. $\quad 96$

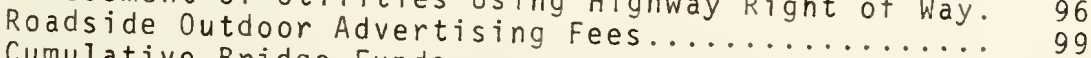

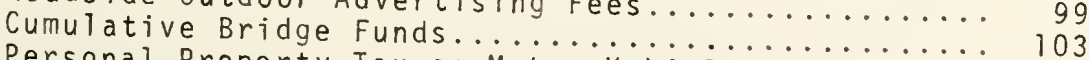

Personal Property $\operatorname{Tax}$ on Motor Vehicies................... 103

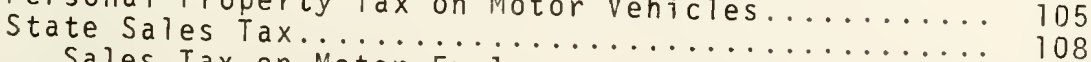

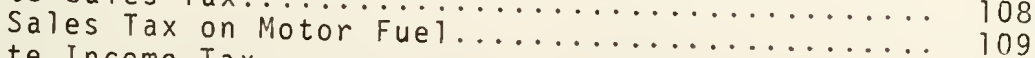

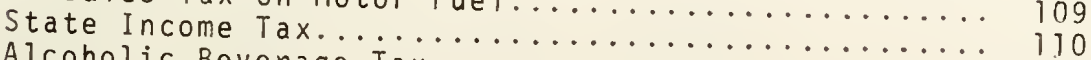

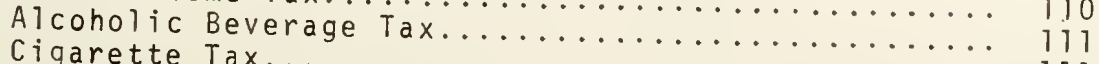

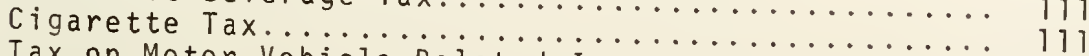

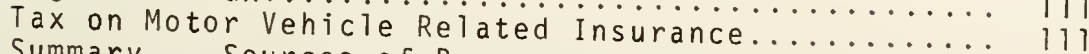

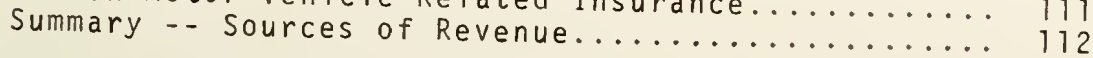




\section{TABLE OF CONTENTS (continued)}

Page

CHAPTER $V$. DISTRIBUTION OF HIGHWAY USER REVENUES .... 116

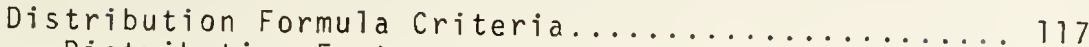

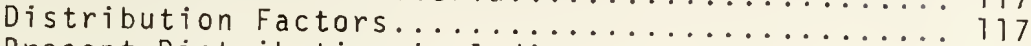

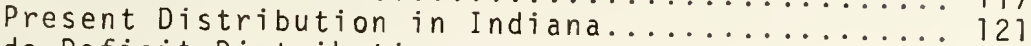

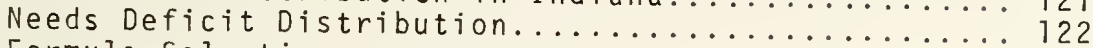

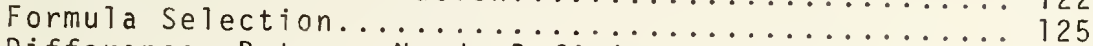

Differences Between Needs Deficit and Distribution... 128

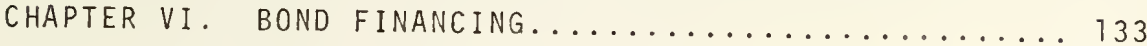

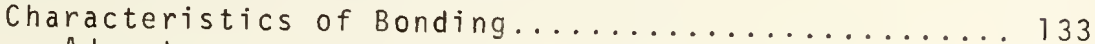

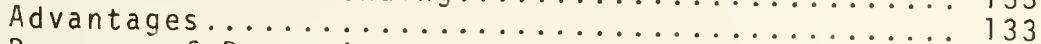

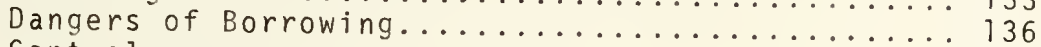

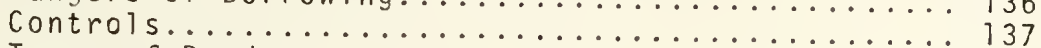

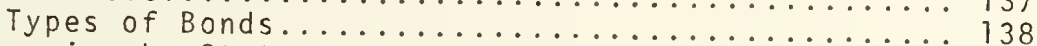

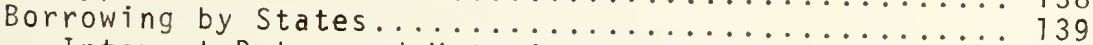

Interest Rates and Maturity schedules................ 140

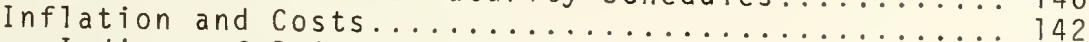

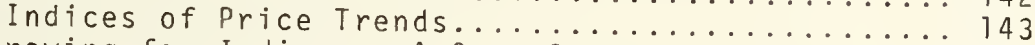

Borrowing for Indiana - A Case study...................... 145

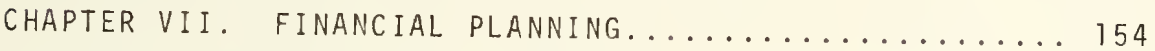

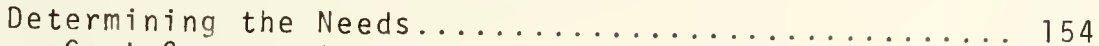

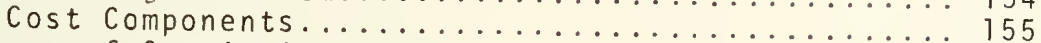

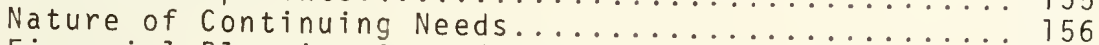

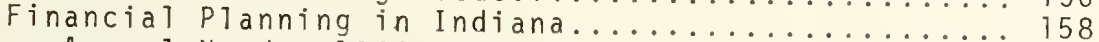

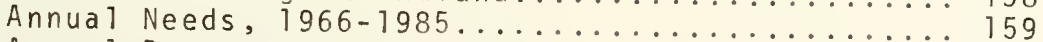

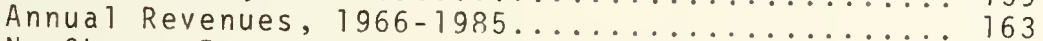

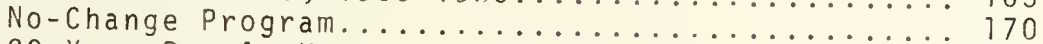

20 Year Pay-As-You-Go Catch-up program................ 171

Catch-up Program of Less than 20 yeras............. 171

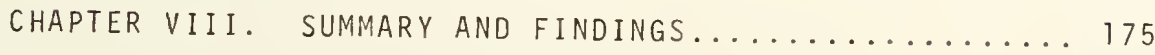

BIBLIOGRAPHY ........................ 183

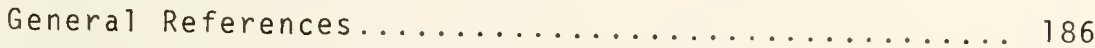

APPENDIX A: M.V.H.A. FUND DISTRIBUTION TO LOCAL

GOVERNMENT LEVELS, ACCORDING TO PROPOSED

DISTRIBUTION FORMULAS.

APPENDIX B: FINANCING AND NEEDS PROGRAMS,

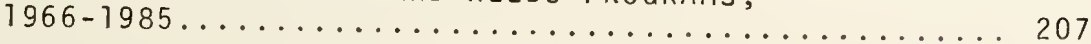


1. Alternative Cost Responsibility Assignments for Average Annual Needs, 1966-1985...........

2. 1966 Passenger Vehicle Registration Requirements in the United States..............

3. Third Structure Weight-Distance Taxes by

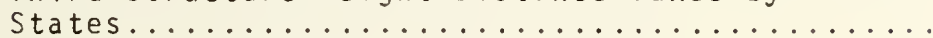

4. Third Structure Gross Receipts Taxes by

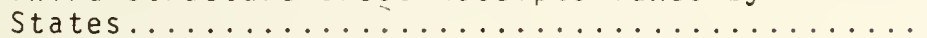

5. Federal Excise Taxes on Motor Vehicles and

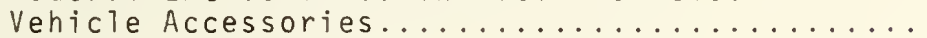

6. Outdoor Advertising Signs on Interstate and Federal Aid Primary Highways in Indiana (1966)..

7. Possible Outdoor Advertising Permit Fee Schedule........................... 102

8. Summary of Sources of Hizhway Revenues and

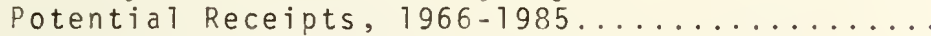

9. Distribution Criteria as Used by Other States... 118

10. Alternative Highway User Fund Distribution

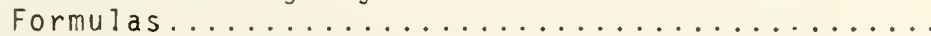

11. Description of Major Road Construction

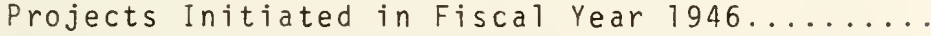

12. Cost of Borrowing in 1946 for 1946 Highway Construction.

13. Construction Cost Responsibility for the State, Counties, and Cities and Towns, for the

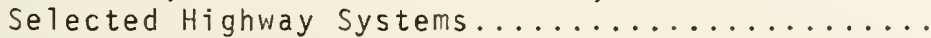




\section{LIST OF TABLES (continued)}

Appendix

Table

A1. Fund Distribution to Urban Areas, Alternative 1... 189

A2. Fund Distribution to Urban Areas, Alternative 2... 191

A3. Fund Distribution to Urban Areas, Alternative 3...193

A4. Fund Distribution to Rural Areas, Alternative 1... 195

A5. Fund Distribution to Rural Areas, Alternative 2... 197

A6. Fund Distribution to Rural Areas, Alternative 3... 199

A7. Total Fund Distribution to County,

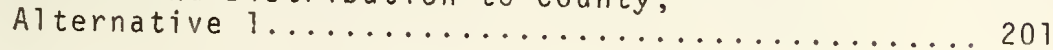

A8. Total Fund Distribution to County,

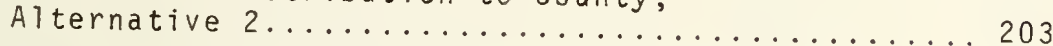

A9. Total Fund Distribution to County,

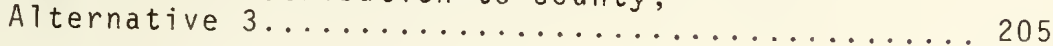

B1. State Financial Program (No Change in Level

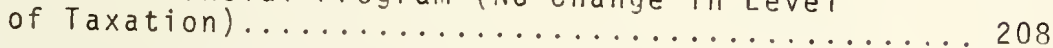

B2. County Financial Program (No Change in Level

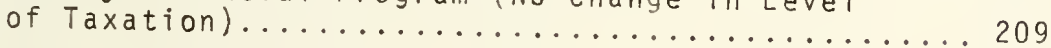

B3. City and Town Financial Program (No Change

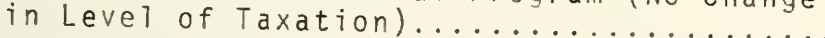

B4. State Financial Program (Tax Increase to Eliminate Backlog in Twenty Years)............211

B5. County Financial Program (Tax Increase to Eliminate Backlog in Twenty Years)............ 212

B6. City and Town Financial Program (Tax Increase to Eliminate Backlog in Twenty Years).......... 213

B7. 10-Year Catch-Up Program for the State

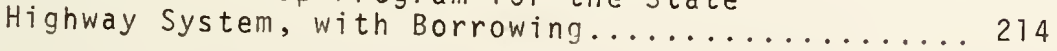




\section{LIST OF FIGURES}

Figure

1. Vehicle Miles of Travel in the United States,

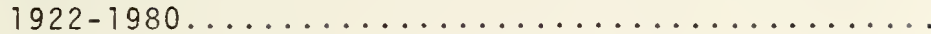

2. Existing and Proposed Highway Systems by

Mileage and Annual Costs, 1966-1985...........

3. Supply Demand Relationship in the Pricing of

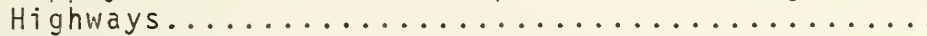

4. Short-Run User Demand and Cost Relationships

for Average Cost and Marginal Cost Pricing......

5. Demand Criteria for Determination of a Non-

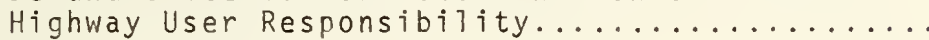

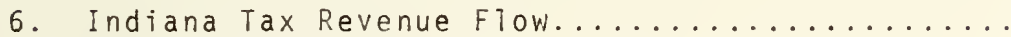

7. Revenue Sources by Percentages for Financing

Indiana's Highways Roads and Streets...........

8. Total State Revenues for Financing Highways,

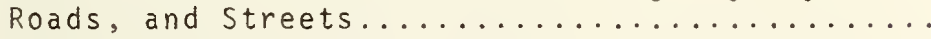

9. State Revenues for Financing Highways

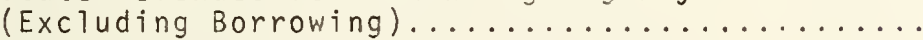

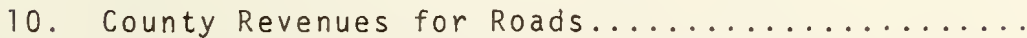

11. City and Town Revenues for Roads and Streets....

12. Comparison of Motor Fuel Consumption Rates.....

13. Indiana Motor Vehicle Registrations............

14. Registration Fee Schedule for Motor Carriers....

15. Indiana County Assessed Property Evaluation, $1959-1985$.

16. Average Annual Needs for Counties, 1966-1985

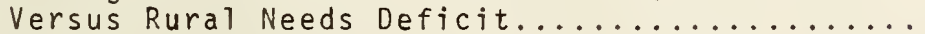


Figure

17. Average Annual Needs for Cities, and Towns, 1966-1985 Versus Urban Needs Deficits...........

18. County Population Vs. Assessed Evaluation......

19. County Population Vs. County Motor Vehicle

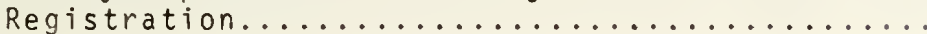

20. State Obligations for Highways, Net Interest

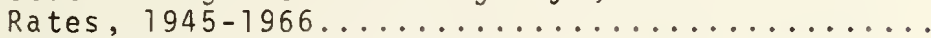

21. General Price Trends in The United States,

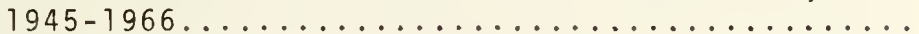

22. Price Trends for Federal-Aid Highway

Construction, $1946-1966(1957-1959=100) \ldots \ldots \quad 146$

23. Location of Case Study Construction Projects.... 148

24. State Highway Needs, 1966-1985 (No Change in

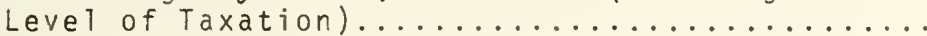

25. County Road Needs, 1966-1985 (No Change in

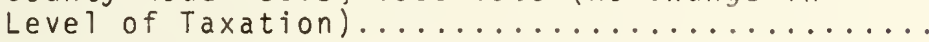

26. City and Town Street Needs, 1966-1985 (No Change in Level of Taxation).

27. State Highway Needs, 1966-1985 (Revenues

Increased to Eliminate Backlog in Twenty Years).

28. County Road Needs, 1966-1985 (Revenues Increased to Eliminate Backlog in Twenty Years)..........

29. City and Town Street Needs, 1966-1985

(Revenues Increased to Eliminate Backlog in

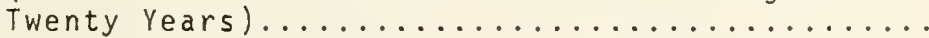

30. 10-Year Catch-up Program for State Highway

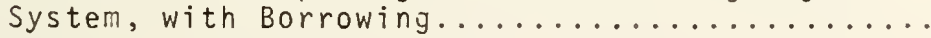




\section{ABSTRACT}

Michael, Harold I., and Metcalfe, James A., FINANCING THE HIGHWAY NEEDS OF INDIANA, Joint Highway Research Project, Purdue University, Lafayette, Indiana, February 1969.

The purpose of this study was to investigate the financing of Indiana's future highway needs between 1966 and 1985 as determined by the 1967 Indiana Highway Needs Study. Included in the study is a discussion of the general theories of highway finance and taxation, with specific references to the cost allocation question and the issue of marginal versus average cost pricing. To provide a basis for financing the future needs, estimates are made of the average annual 1966 to 1985 revenues from various presently used as well as new tax sources.

Though not presently permitted by Indiana, the borrowing device has proven quite successful in many states in assisting in the carrying out of a highway improvement program. To better understand the application of borrowing to the financing of highways, an appraisal is made of the merits and drawbacks of a debt financing policy. The total cost of borrowing is demonstrated using a case study of a hypothetical borrowing program initiated in 1946.

In addition to estimates of future revenues, this study includes an analysis of the distribution of highway funds 
among local government units, both as used by other states and as might be used by Indiana. As a measure of distribution the criteria of "needs deficit" is proposed. Though distribution according to needs or needs deficit is desirable, these measures are difficult to establish on a continuing basis. For this reason a more commonly accepted distribution rationale is distribution according to factors symptomatic of needs. Accordingly, representative measures of needs deficit were determined using a stepwise linear regression analysis, performed on many symptomatic factors presently used in Indiana and in other states. Of the many equations generated, the most acceptable were selected and presented herein.

Finally, the programing of future highway revenues necessary to finance the needs is discussed and presented in the form of a no-change program, a pay-as-you-go program, and a short term catch-up program. It is evident from this analysis that the no-change program will only further aggravate the already critical need for highway improvement in Indiana. 
CHAPTER I. INTRODUCTION

Since the advent of the automobile early in the twentieth century there has been an unprecedented growth in the use of the motor vehicle. There are presently (1967) over 81 million passenger cars and 16.5 million buses and trucks in the United states [1]*. This number is expected to reach 120 million by the year 1980 and 200 million by the year 2000. Correspondingly, annual vehicle miles of travel now (1967) totalling approximately 967 billion will reach 1300 billion by 1980 and 2000 billion by the year 2000 (see Figure 1), more than double the present travel [2].

As a result of this growth those responsible for providing highways have been continually faced with the problem of financing needs which typically have far outstripped revenues. If the estimates of future highway travel prove to be correct, this highway needs gap can only increase unless measures are soon taken to reverse the trend.

\section{Indiana Highways}

Over the years Indiana has developed a highway system of about 91,000 miles. This system is presently structured

Numbers in bracket refer to items in Bibliography. 


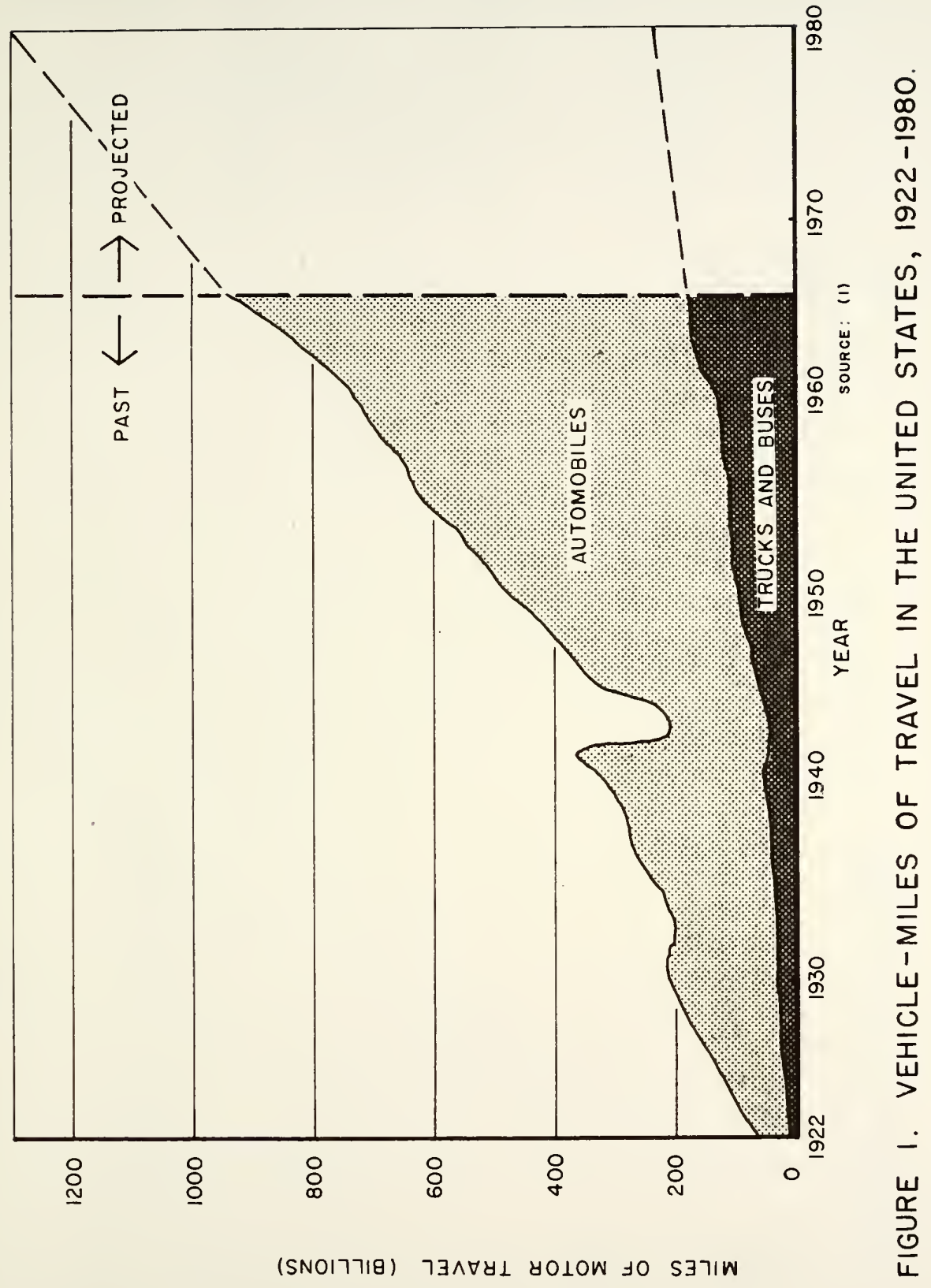


and administered under three governmental jurisdictions:

\begin{tabular}{ll} 
Jurisdiction & Miles \\
\hline State Highway System & 11,297 \\
County Roads System & 67,999 \\
City and Town Streets & 11,694
\end{tabular}

In 1966 there were $2,069,685$ automobiles and 480,854 commercial vehicles registered in the state. It is estimated that by 1985 total registrations will be $3,164,000$ automobiles and 704,000 commercial vehicles, an increase of 53 percent. Concurrent with this increase, motor vehicle miles of travel are expected to reach 41 bilition miles by 1985 [3].

Though the adequacy of Indiana's highway effort can, in the final analysis, only be evaluated by its residents, a comparison with the rest of the U.S.A. gives a relative evaluation. When ranked with the other 49 states Indiana rated in 1966 as follows:

Factor

Population

Area

Miles of Roads and Streets

Total expenditures for highways

Expenditures per mile

Expenditures per capita $\underline{\text { Rank }}$

In 1967 residents of Indiana spent an average of $\$ 59 /$ person on highways as compared to a national average of 
$\$ 65 /$ person. A consideration of the above in conjunction with the estimated growth in highway demand suggests that increased effort will be required if Indiana is to keep pace with the public's demand for better highways, roads and streets.

The recently completed Indiana Highway Needs and Finance Study "Guidelines for Progress" estimated that highway needs in Indiana between 1966 and 1985 will total over $\$ 10$ billion $[3,4]$. On an average annual basis this amounts to the following for each of the three highway jurisdictions.

Jurisdiction

State Highway System

County Road System

City and Town Streets

Tota 1
Average Annual Need

(\$Millions)

252

184

86

522

Figure 2 indicates these needs for both the existing and proposed (by the Needs Study) systems as compared with the estimated average annual revenues for the same period. The findings of the Needs Study indicate that with current revenue sources maintained at current rates, Indiana will have an average annual needs deficit of $\$ 187$ million for the period $1966-1985$.

In light of this estimated deficit of needs there are three alternatives available to the decision makers of Indiana in their formulation of future highway policy:

(a) Lower the standards for level of service and safety (as established 


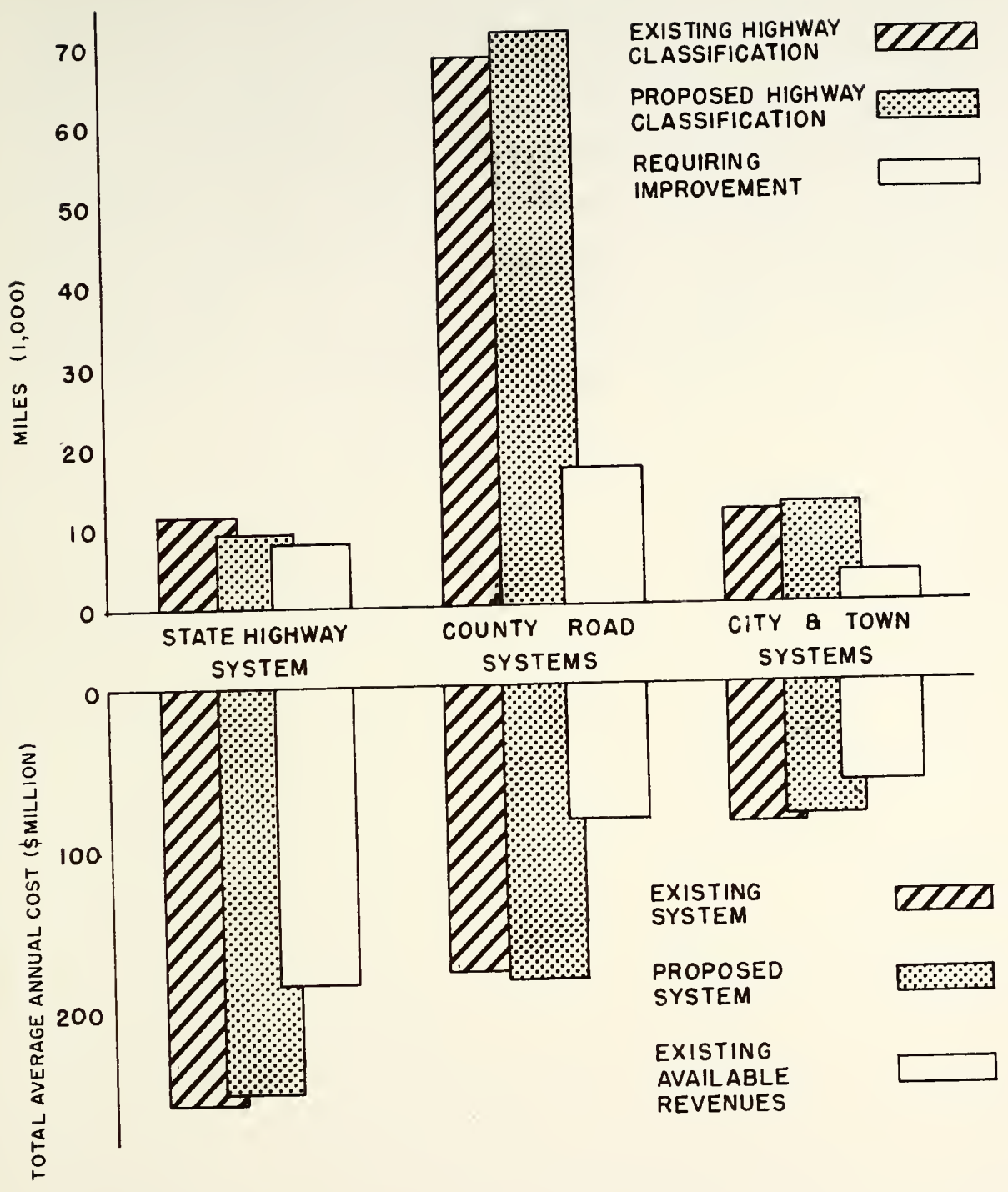

FIGURE 2.

EXISTING AND PROPOSED HIGHWAY SYSTEMS BY MILEAGE AND ANNUAL COSTS, 1966-1985. 
by the needs study; (b) Increase revenues through increased taxes to meet the needs; or (c) Partially increase revenues and lower standards. This decision should be made on the basis of what standard or level of service people demand. The extent of this demand will, for the most part, be indicated by the willingness of the people to support necessary tax increases. It is the intent of this study to provide guidelines for the development of such policy. 
CHAPTER II. THEORY OF HIGHWAY FINANCE

The decision-maker when evaluating questions of public policy toward highways must ask the questions: Is the investment justified? How much investment is justified? In what form should charges be levied to support the investment? Which individuals or groups should pay the charges? He must in addition conduct this evaluation recognizing that resources are limited and that expenditures for highways must compete for these resources with all other publicly supported activities and personal needs.

\section{Investment Decision}

The justification of any investment can be determined by answering two questions. First, will the gains or benefits from the investment exceed the costs? If not, the investment should not likely be made. If so, the second question must be asked. How do the anticipated gains from this investment compare with those from other possible investments? In the highway context these questions are, do the benefits to society from the investment exceed the costs of the investment and do such benefits exceed those of other investments, such as for education or defense? Currently, the answer to the second part of this question appears to 
come more from the inherent competition for limited public funds than from rigid economic evaluation. The answer to the first part has, however, lent itself to more rigorous analysis and evaluation.

\section{Needs Studies}

The traditional guideline for the highway investment decision has been the "Highway Needs Study." These engineering and finance studies have evolved to assist in the formulation of legislative and engineering policies for the provision of highway transportation. The basic objective of a needs study is to determine the adequacy of the transportation system, to suggest methods for its improvement, and to inform the public of the costs of these improvements. A report prepared by the U.S. Department of Commerce, Bureau of Public Roads [5], "Creating, Organizing and Reporting Highway Needs Studies" states that a highway needs study should include:

1. An engineering appraisal of highway and traffic conditions and identification of needed improvement to rural roads and city streets.

2. A study of finances related to highway affairs.

3. A review of highway iaw.

4. A study of administrative practices and regulations of highway agencies.

The report continues by adding that a comprehensive highway needs study should set out to answer the following questions: 
1. What are the social and economic factors which cause and will continue to cause a demand for the improvement of highway transportation facilities and services and how may these factors be measured?

2. What classes and types of highways, how many miles of each are needed to supply present and expected future needs, and what will it cost to build and maintain them?

3. Can the state and its subordinate governmental units finance the needed expenditures under current tax levies and, if not, what are the alternate financial proposals?

4. How can the several road and street systems be most effectively administered?

It will quickly be noted that the above outline makes no mention of benefits derived from highway improvement or a comparison of costs vs. benefits. The needs study approach would thus appear not to answer the basic investment question, do benefits exceed costs. It may be argued in support of the needs study approach that in the absence of quantitative measures of social benefits the ultimate acceptance or rejection of the needs rests with the willingness of the people to vote the necessary taxes to carry out the proposed expenditures. That is the individual must make his own assessment of the benefits to be derived from highway improvements as compared to his personal outlays in the form of taxes, 
and based upon this assessment, express his agreement or disagreement with the needs study proposals.

\section{Economic Analysis}

A more quantitative approach to answering the investment question is accomplished with the aid of economic analysis techniques. These techniques such as the benefit cost ratio or rate of return have in recent years achieved wide acceptance in the analysis of project alternatives [6]. These analyses have however been limited to the evaluation of single projects or transportation links and have rarely if at all been applied to a complete transportation system. The application of economic analysis to the investment question for an entire transportation system would appear to be a logical extension of current application. Guidance provided by the quantification of benefits or project returns could lead to a more rational and defensible measurement of future highway needs.

\section{Pricing Decision}

The third and fourth questions of public policy, in what form should charges be levied and which individuals should pay the charges are primarily questions of pricing.

In any discussion of transportation pricing a clear definition of the transportation service must be first resolved. From an economic viewpoint, transportation has two functions, as a "final" service in the case of the "Sunday 
drive" or pleasure trip, wherein the trip in itself provides the desired end product or return, or as an "intermediate" service such as for al1 goods movements or for the work trip, wherein the return is achieved at the trip end. Outlays for intermediate service from the point of view of the shipper or traveller can be considered as a necessary cost to achieve some objective at the termination of the trip whether in the form of profits or a paycheck.

As strictly pleasure trips constitute only approximately ten percent of trips made and these in hours of low travel demand, the pricing of transportation, in this instance highways, as a factor of production, would appear justified.

The provision of highway transportation can for the most part be assessed from the economic point of view of supply and demand. It is argued that certain collective benefits such as for development of resources and national defense must be considered beyong the conventional scope of supply and demand. This argument is valid to a certain stage of supply, however provision of facilities in developed countries would appear beyond the stage of basic mobility and more a response to the motoring public's demand.

It will be recalled that the typical supply-demand relationship can be depicted by the curves in Figure 3 , wherein the demand curve Dd is downward sloping to the right (as price decreases, logically total use or output will increase), and the supply curve $S$ s is upward sloping to the 
12

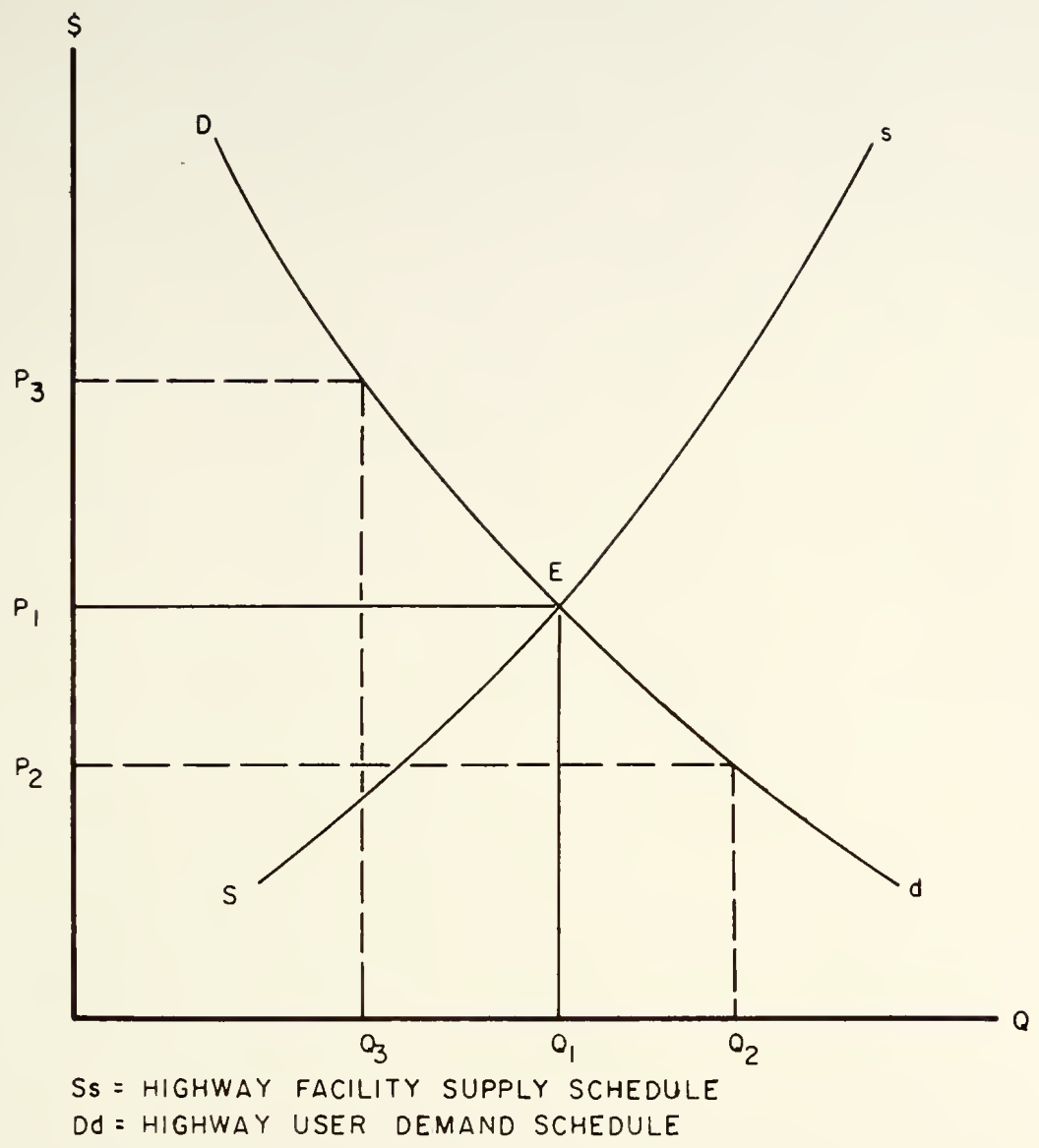

FIGURE 3. SUPPLY - DEMAND RELATIONSHIP IN THE PRICING OF HIGHWAYS 
right (as price increases supply will usually also increase). The intersection of the supply and demand curves, point $E$ is the equilibrium condition and thus the market price, i.e., the price people are willing to pay for a commodity.

There are two characteristics of this relationship as applied to highways which are noteworthy. First the demand curve for highways has proven to be relatively steep vertically; in other words demand for highways appears to be inelastic. It will again be recalled from basic economics that inelastic demand in the market place refers to the condition under which an increase in price will evoke so small a decrease in output that total revenues will rise. In the case of highways then, it can be said that a price increase, within moderate limits would result in only a slight if not negligible decrease in highway use.

The second characteristic related somewhat to the first is that if the price of highway use is set lower than the equilibrium price $P_{1}$ at $P_{2}$ the demand will exceed the supply and continue to do so unless supply can be increased sufficiently to meet the new demand. Conversely if price is set above the equilibrium price at $P_{3}$ then supply will exceed demand. The former case, wherein demand exceeds supply as evidenced by congested highways, roads and streets, appears to be the more prevalent condition; that is the price for highway use, at least where congestion exists, appears too low. 
Setting the Price

There are two basic philosophies which pervade the field of highway pricing. The first looks upon highway pricing strictly as a means of obtaining revenues. The second and that supported by many economists suggests that highway pricing should be used as a rationing device to maintain supply-demand equilibrium with the collection of revenues as only a secondary benefit.

The current tax structure of uniform gas taxes, registration fees and various other user charges is based on a policy of average pricing for obtaining revenues sufficient to cover the fixed and variable costs of highway supply. With this policy each user, within similar user groups such as all passenger cars, pays at approximately the same rate and experiences approximately the same conditions of travel.

supporters of the second pricing philosophy suggest that marginal costs and not average costs should be charged for highway use. It will be recalled that marginal cost is the added or incremental cost of producing one additional unit of output. Short-run marginal cost assumes that facility supply is fixed; long-run marginal cost assumes that facility expansion is unrestricted. As related to highways, marginal cost for a vehicle can be looked upon as the cost to society, mainly other highway users, of adding one additional vehicle unit to the highway system. 
Figure 4 depicts the typical relationship between shortrun average cost and marginal cost, wherein the marginal cost is equal to the slope of the average cost curve. Od will be assumed to represent the demand curve for highway use. An average pricing policy will result in a price $P_{1}$ and output $Q_{1}$. A marginal pricing policy will result in a price $P_{2}$ and output $Q_{2}$. In the case where $Q_{1}$ is greater than the supply, i.e., the desired volume is greater than capacity, and where congestion is unacceptable, the marginal price $P_{2}$ would reduce the output or volume to $Q_{2}$. The difference $P_{2}-P_{1}$ could then be looked upon as a "congestion toll." (Congestion tolls will be discussed later.) This toll would have the affect of diverting those unwilling to pay price $\mathrm{P}_{2}$;

1) to other facilities;

2) to other modes such as mass transit;

3) to other time periods;

4) from making the trip at all.

The arguments which these two pricing policies have engendered are many and $i t$ is not the purpose here to support or reject one or the other. However several observations are possible.

1. It was previously stated that highway investment is justified if social benefits exceed costs.

Thus where the benefits to society from expanding a facility are greater than the costs of expansion it would seem unwise to restrict this expansion by means of a pricing policy. 


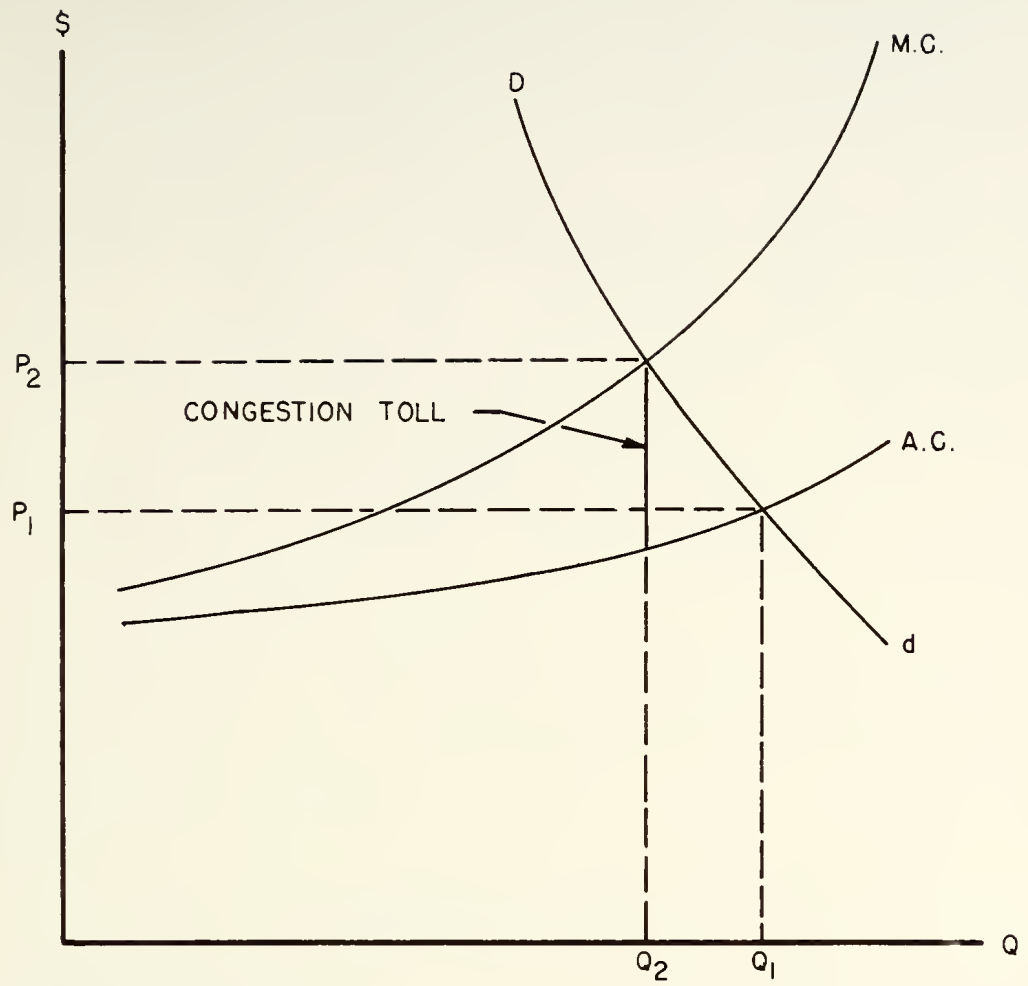

Dd = USER DEMAND

M.C. = MARGINAL TRAVEL COST

A.C. = AVERAGE TRAVEL COST

FIGURE 4. SHORT-RUN USER DEMAND AND COST RELATIONSHIPS FOR AVERAGE COST AND MARGINAL COST PRICING 
2. When increases in supply can be achieved at a total social cost lower than the cost of a congestion toll then expansion of supply would again appear warranted.

3. Where expansion is unjustified or impossible, such as is becoming the case in many urban areas, and where congestion persists, a marginal pricing policy would seem to offer a possible solution. Not only would the highway facility be used at a more acceptable quality of service but also use of mass transit would be encouraged.

In summary then both average and marginal pricing policies would appear to have applications in the future policies of highway pricing.

\section{Taxation Principles}

Throughout the long history of public taxation, three basic principles around which most of today's tax policies are woven have developed [4]. These are known as the ability-to-pay, the benefit and the socio-economic principles.

$$
\text { Ability-to-Pay }
$$

The ability-to-pay principle states not only that the rich should pay more but also that those equally situated should pay the same taxes. This principle has traditionally become imbedded in political and social, as well as, public conceptions of tax equity. Over the years it has formed the basis for the progressive taxes, the most prominent 
example being the income tax. Economists have endeavored to show that it is based upon sacrifice theories derived from an assumption of diminishing marginal utility on rising income; however, due to numerous conflicts with other taxation principles they have found it unsatisfactory as the controlling principle of taxation.

\section{Benefit Principle}

According to the benefit principle those persons or groups who receive benefits should pay in accordance with the benefits received. A restriction of the benefit principle is that it can be applied only where the beneficiaries can be clearly identified. As a result considerable criticism has formed against benefit taxation on the grounds that government expenditures are presumed to serve the overall public, thus benefits received are often diffused and shifted throughout society and rest with no one discernible group or individual. Many categories of public expenditure, such as education, health and unemployment relief, do fall into the category of taxation for the advancement of the general public welfare without definition of the benefits received. There are, however, government activities which provide direct and measurable public service. One such service is the provision of highways and streets; this is a service which is for the public welfare, but it is also one for which at least some of the benefits received by the highway user are readily measurable. 


\section{Socio-Economic Principle}

In recent years formulators of taxation policy have directed more of their attention toward taxation for the overall public economic welfare as opposed to simply taxation for obtaining revenues. Economists argue that taxation policy should be directed to achieve the optimum balance of economic, social, and political conditions to achieve the fullest benefit to the individual. Although such an approach to taxation has many practical limitations, the general welfare or socio-economic principle does enable economists and politicians to consider taxation policy in light of its potential effect on the entire community.

Benefit Principle Governs

Each of these principles is in part acknowledged as being included in today's concepts of highway taxation; however, the benefit principle has achieved the governing role in the formulation of modern highway fiscal policy.

\section{Taxation Objectives}

The benefits of highways to those who use them take numerous forms. Savings in travel time and operating costs, reduction of accidents and increased comfort and convenience are well accepted as user benefits derived from highway improvements. To those who use highways in the conduct of their business, the trucking industry for example, some benefits of highways can be directly measured in the form of 
profits. The increasing use of trucks for the movement of goods both for short and long overland hails, is a sionificant indication of the level of these benefits.

$$
\text { Benefits from highuys, also accrue to the non-user, }
$$

though they are less eas" 'y measured. Hi nways have shared zreatly in the deveiopment or the ration by opening uo new and nreviously unused land to irrustry and agricuiture. Imoroved access and reduced $t$ ans=ortation costs are encountered dail: in the ease with wh ch coocs are trarsoorted throughout the nation. vione directiy, highay and street iprove ents provide access to private ard comrercial lands, and are responsibie for ircreases in and va?ue aion their corridors. These, as weil as numerous other benex-s rom hiahways are enjoyed throughout the nation by alrost every e ber of the population. The diversity of benefits derived from highway improvements to snciety as a whole, rowever, has confounded the formulation ot definitive measures of bereFits and fostered the conflict between the pubiic and the user.

Though a theoreticaily sound basis for separating user and non-user shares of cost resnonsibi? ity has not as yet been developed, the sractica? proble of makin this decision has remained with the policy maker. Efforts to quantify the division of responsitulity within some rationai framework have been somewhat guided by the basic objectives of equity, neutrality, and budgeting. 


\section{Equity}

Many groups benefit from the provision of highway facilities. If they are to be assessed according to the benefits received, taxation should be structured toward levying taxes in accordance with the level of benefits received; in other words each individual or group should pay its fair share of highway costs.

\section{Neutrality}

In the determination of the share of costs to be assessed against various user groups, the fact should be considered that highways are in essence a mode of transportation competing with other modes such as air, rail, and water. For example, the trucking industry, a competitor to air, rail, and water systems, uses the highways as a major component necessary for the conduct of its business. The government in subsidizing highways or by taxing the users should not give any one mode an unfair advantage over the others. Fo ensure this consideration, the public's share of highway costs should not override the cost responsibility incurred by the trucking industry in its use of the public road system.

\section{Budgeting}

The framework of taxation for highways should be oriented toward maintaining continuity of revenues thus enabling scheduling of future improvements. A logical and uniform 
basis of allocating costs enables prediction of future revenues and ensures fund availability for planning for long range objectives.

\section{Cost Allocation between User and Non-User Groups}

The general acceptance of the benefit principle for highway taxation and the receiving of benefits by users and non-users alike necessitates the formulation of a rational procedure for assessing each group with its share of total highway costs. Though the methods conceived to date are approximate, a more theoretical determination of cost responsibility has thus far defied definition. Existing approaches, however, provide a useful guide to the decision-maker. The majority of the methods which have been employed in various cost allocation investigations are described in some detail in the "Final Report of the Highway Cost Allocation Study" 1961, to the U.S. Congress and are briefed in the following paragraphs [7]. A more recent summary is offered in a paper by A. D. Lebaron [8].

\section{Added-Expenditure Method}

This method, used by early investigators, based the allocation of user and non-user shares on a comparison of current highway costs with those of the pre-motor vehicle era. Although this procedure had some validity in the early stages of motor-vehicle transport it is completely unrealistic for analysis of the present day problem. 
Relative Use and Predominant Use Methods

The relative use approach allocates tax responsibility between motor-vehicle users and others in accordance with the extent to which different classes of roads render service to through traffic as distinguished from local or neighborhood and access service. The application of the procedure requires utilization of extensive traffic volume, origin destination and trip length data - - information which is at best usually sketchy or unavailable on a state wide basis. To avoid the need for such extensive data, other investigators have preferred to allocate to different road and street systems 100 percent motor-vehicle or non-motor vehicle tax responsibility in accordance with the predominant character of the service rendered.

\section{Earnings-Credit Method}

This procedure applies some of the ideas of the relative use method and is applied according to the following propositions: Road users should be assessed fees for all travel at a rate which is sufficient to support alone the top systems of arterial and primary highways, rural, and urban; and non-users should be assessed fees for each mile of highway which is sufficient to support alone the bottom, or lowest systems of access roads and streets. A compromise is then drawn between each of these solutions to cover responsibility for all systems. It is this approach which the Indiana Needs Study, as well as many other states, selected 
for the determination of user and non-user cost responsibilities.

Each procedure outlined above is rather arbitrary in nature and can be criticized for lack of theoretical sophistication. However, the assumption that the major users of a facility should support it, as with the relative use procedure, or that users should support through traffic facilities and non-users should support facilities strictly for local access, as with the earnings-credit methods are conceptually reasonably sound. A major difficulty with each of these procedures is the classification of each section of highway, road or street into the proper category. Yet until continuing research provides better solutions to cost allocation between users and non-users, the methods presently available provide useful guides to the decision maker.

\section{A Theoretical Approach}

Contrary to current practice as just outlined many economists are urging the view that non-user contributions should be made to the support of highways only when user charges would fail to meet the cost of providing the necessary facilities [9].

Non-user charges are in essence a form of subsidy to the highway user. The general theory of public subsidy states that subsidies may be granted to encourage an expansion of production and consumption only if the market economy fails to produce a sufficient quantity of those goods 
which yield significant indirect benefits or external economies. When related to highways then on the basis of this theory, non-user charges should only be specified when they will further encourage highway use and through this use provide economies or benefits to the non-user. This approach differs considerably from current practice in that rather than an arbitrary across the board determination of the nonuser charge in proportion to benefits received, the analyst should first justify the need for a non-user share at all. Figure 5 represents a graphical determination of those conditions justifying a non-user subsidy.

As discussed previously some economists argue that marginal cost pricing should be employed for highways. For Case I, Ddu represents the user's demand for highway service, the point $p$, the intersection of the marginal cost curve and the demand curve, is the price he is willing to pay for output $\mathrm{q}$. Demand curve $D d_{n}$ represents the demand which a non-user may have for the users use of the highway. This demand will exist as a result of external economies received. Assuming that the non-user is actually willing to pay for the user's highway use the total demand for highway use will be the vertical sum of $D d_{n}$ and $D d_{u}$, indicated by $D_{T}$. If this new demand or output curve intersects the marginal cost curve to the right of $\mathrm{Dd}_{u}$ then total output is increased and a subsidy is justified. However, if curve $D_{T}$ does liot intersect the marginal cost curve then the non-user's demand has 

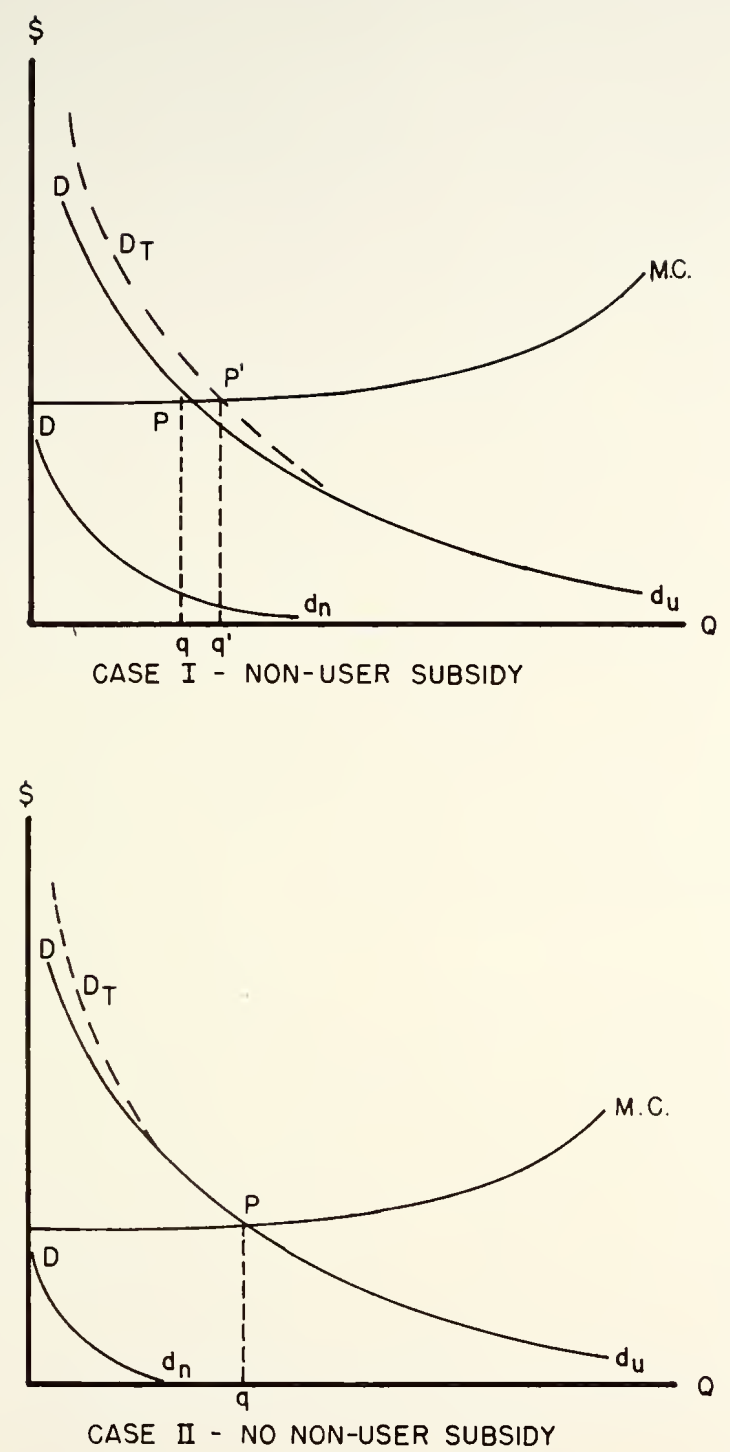

FIGURE 5. DEMAND CRITERIA FOR DETERMINATION OF A NON-HIGHWAY USER RESPONSIBILITY. 
ro effect on total user output; thus a subsidy is unjustified, as indicated in case II.

A criticism of this approach might be that collective economies such as economic growth and national mobility are not considered. Certainly in developing regions where transportation is a necessary pre-requisite to these demands, government subsidy would appear justified. For the most part, however, transportation needs in the United States are more a response to direct demand of the motorist rather than a stimulus to economic growth. Another consideration of non-user highway support is the influence which it has on the commercial transportation industry. A non-user subsidy of highways must be carefully considered if neutrality among transportation modes is an objective, to ensure that the trucking industry is not being given a cost advantage over other transportation modes.

Whenever a consideration is made of external economies resulting from highway improvements, account should also be taken of external diseconomies; namely, such factors as land pollution, noise, and other community disbenefits resulting from highway expansion. Perhaps if non-user support is to be given to highways as payment for benefits received, then user charges should in return be transferred to the support of community resettlement, pollution control, and noise abatement.

To be sure the above approach suffers as a result of difficulties in ease of application. It does, however, 
provide a more rational and justifiable approach to the question of user, non-user shares in the support of highways.

\section{Cost Allocation Among User Groups}

In addition to the allocation of cost between user and non-user groups detailed study prompted by the demands for equity as well as neutrality in cost assignment, has been conducted by many persons into the cost responsibility of various user classifications [8]. The considerable variation in size, weight and operation of motor vehicles using highways from small passenger vehicles to large tractortrailer combinations gives rise to the difficult problem of determining the costs incurred by each vehicle type and thus its cost responsibility. Certain design features of the highway, for example bridge loading capacity, pavement thickness, and grades are controlled for the most part by the larger vehicles.

Several propositions have developed over the years for the determination of the fair assessment for each vehicle type; these will be discussed briefly in the following paragraphs. A more complete discussion of each may be found in the Final Report of the Highway Cost Allocation Study [7].

\section{Differential Benefits}

This approach attempts to assign cost responsibility based on benefits received by the user group in the form of reduced operating, time and accident costs, and reduced driving strain. A difficulty encountered with this method 
is the assignment of accurate dollar values to the benefits received.

\section{Operating Costs}

Like the differential benefits approach the operating costs method assigns cost responsibility in proportion to benefits received. However, in this case, it is assumed that motor vehicle operating costs, which rise steadily with vehicle size, may be taken as a measure of the value of service provided and thus are a measure of cost responsibility.

\section{Cost Function}

This approach assumes that every item of highway cost can be placed in one of three categories: (1) Costs that vary neither with traffic volume nor with size and weight, and may therefore be distributed among all vehicles on a uniform basis; (2) Costs that vary with use of the highways but not with size or weight, and may therefore be distributed among vehicle classes in proportion to vehicle-miles traveled; and ( 3 ) Costs that vary with size or weight, and should therefore be distributed in accordance with some size or weight function.

\section{Gross Ton-Mile}

The gross ton-mile method is one of the most commonly proposed procedures for allocating highway costs among users. Conceptually it is based on the contention that ton-miles 
reflect relative highway use and thereby the relative benefits accruing to the different vehicle types. The popularity of this approach is probably due to its simplicity. Critics argue, however, that vehicle weight is not a major determinant of highway construction cost and that there is little concrete evidence of a measurable relationship between ton-miles of travel and cost occasioned.

\section{Incremental cost}

This method is probably the most theoretically sound approach to the assignment of user responsibility. The concept is that there is a "basic" highway required for all vehicles, even the lightest, smallest passenger vehicles. The cost for such a highway is assigned equally to vehicles of all sizes and weights. Added design features required for other vehicle classifications are then assigned to all groups requiring them. Successive increments of cost are then added to meet the requirements of progressively heavier vehicles. Until recentiy, the detailed data required on vehicle types and operations prevented wide application of this technique; however, extensive research projects, specifically the ASSHO Road Test, have provided much necessary detailed information. Recent state cost allocation studies, including Indiana's Needs Study, employed this method of assigning user cost responsibilities.

Each of the above methods has its vigorous supporters and critics and because none of them provide indisputably 
accurate findings, there is no way to prove that one method is correct while another is incorrect.

\section{Problems of Financial Administration of Highways}

Thus far the discussion of highway finance has been based on the assumption of an a priori justification to finance highway needs determined by a Needs Study. It must be remembered however, that highways must compete with other government functions for every dollar spent. Thus arguments for diverting funds from the General Fund or increasing taxes for highway purposes must be weighed in light of other government needs. There is no justification for expending funds on highway facilities when the return to the public will be less than that for spending on other government functions bringing a higher return. This notion is not new to the administrator; however, the needs of one area are sometimes forgotten with concentration upon the needs of another.

\section{Diversion}

The demand for funds from all sectors of government responsibility has given rise to vigorous argument around the topic of fund diversion. Highway-proponents argue that user-tax funds should only be spent for highway purposes. Since the willingness of the motorist to pay user taxes may be taken as a measure of his assessment of the highway need, the contention is that a use of the funds for other purposes would be an unjust disposition of taxpayers' money. 
Opponents of this viewpoint argue that "...the state should be free to expend its resources to maximize returns" [10]. In other words, the only way to optimize the public welfare is to allow the government to distribute tax revenues among its various agencies in the optimum manner.

Though argument from both sides continues, the majority of states have constitutional amendments prohibiting diversion of highway funds to other purposes [11]. Indiana though not having such legislation, in its definition of how highway funds are to be spent, does in essence prevent fund diversion in that al1 highway user revenues are placed in a special fund, the Motor Vehicle Highway Account, earmarked specifically for highways. In 1966, of the $\$ 185,044,000$ user revenues available for distribution, only $\$ 900,000$ were spent for general state purposes. An additional \$7,600,000 was used for the support of the state police for their patrol of highways and safety programs.

\section{Dispersion}

Dispersion is the expending of user revenues on facilities other than those upon which they were earned; in other words user-taxes paid by through traffic on primary and arterial highways are used to support local access facilities. Though absolute control of user revenues as applied to each roadway classification is nearly impossible, the proper allocation of costs between users and non-users and the wise distribution and collection of funds to and by 
the different government levels can prevent major injustice in this respect.

\section{Reciprocity}

A major difficulty encountered by state highway administrators in establishing a highway taxation structure is that of assessing interstate vehicles with their fair share of a state's highway costs. Passenger vehicles with their limited fuel carrying capacities are usually forced to pay some tax in each state through which they travel. Acceptance of this fact by the states is evidenced by the freedom of travel allowed passenger vehicles throughout the United States.

Increasing numbers of interstate trucks, however, with large fuel capacities are often believed to pass completely through a state without purchasing fuel, thus without paying any tax. Some states, as a result, require in-state registration of all commercial vehicles traveling within the state. To minimize the administrative difficulties caused by such action, many states have reciprocal agreements with surrounding states to allow free passage of vehicles registered in any one of them. These agreements have the advantage of promoting interstate trade, reducing administration and enforcement costs, and being less burdensome to interstate truckers. A difficulty with most reciprocity agreements is that large trucking firms tend to locate in major urban centers, and yet travel throughout the region, thus 
some states may reap greater benefits than others. Another problem has been finding agreement on those fees which are to be waived on interstate trucks by reciprocating states. Present agreements generally include the licensing and registration fees but not the so-called third structure taxes, such as mileage or gross receipts taxes.

Indiana is a member of the southern agreement along with Alabama, Florida, Georgia, Kentucky, Louisiana, Maryland, Michigan, Mississippi, North Carolina, South Carolina, Tennessee, and Virginia. This agreement was established on the basing point concept in that registration is in the state in which the vehicle is based and also in any other state in which it is based for thirty days or more. The Council of State Governments in their analysis "Interstate Relationships in the Taxation of Commercial Vehicles" has suggested five guidelines for the formulation of reciprocity agreements. Such agreements should:

1. Provide each state with a share of revenue from the taxation of commercial vehicles commensurate with their highway use.

2. Be non-discriminatory between intra, and interstate commerce.

3. Permit each state to levy its own taxes.

4. Cover all types of commercial vehicles.

5. Be ultimately nationwide in scope [12]. 
Reciprocal agreements have not as yet advanced beyond the stage of including more than a few surrounding states. Thus some states have found it desirable to have measures for assessing fees on vehciles from non-reciprocating states. A discussion of these measures will be included in Chapter IV.

\section{Effects of Increasing User Costs}

To accommodate fulfillment of the recommendations of the Needs Study will, in all likelihood, require increasing the financial support for highways by the user and the pub1ic. Increased cost in the competitive market, of course, may reduce demand. If market competition did exist in transportation, this reduced demand would present itself in the form of fewer trips, decreased use of highways, and reduced congestion. However, the degree to which demand is reduced is a function of the magnitude of the market competitiveness. In the case of highways, competition from other forms of transportation such as rail, water, and air is usually only slight; therefore, a large increase in price would be necessary to effectively reduce demand.

It is estimated that a 7 -cent increase in the motor fuel tax would bridge the estimated Indiana highway revenue deficit. In the opinion of many, such an increase would have 7 ittle effect on the demand for highway services. It is also probable that any combination of tax increases spread over several tax bases to yield an equivalent amount would 
have a similar null effect. If in actuality the legislature were to decide to ignore the public benefits derived from highways by refusing to finance highways from non-user revenues and were to set the cost of highway use so that supply equaled demand, a price increase many times greater than that necessary to fulfill current needs would be required to reduce demand to the point where the specified level of service could be provided by existing highways. 
CHAPTER III. HIGHWAY TAXATION IN INDIANA

\section{Historical Development}

In the analysis of the present highway tax structure of Indiana or or any other government unit an awareness of the development and growth of this structure is essential. A study of this development assists the analyst in achieving both an understanding of the reasons for and nature of present taxes, and an awareness of possible pitfalls and complications of continuing certain existing taxes or instituting new ones.

The history of Indiana highway taxation begins with statehood in 1816. Realizing that Indiana would be unable to support a highway system, with its small population of 65,000 , the Federal government made allowances in the Statehood Enabling Act of 1816 for Federal aid to highway development. To generate revenues for highways, Congress included in the Act a provision for the donation of certain land to the state. This land was then to be sold with 3 percent of the proceeds to be dedicated to local road construction and an additional 2 percent of the proceeds to be dedicated to through road construction. This so called "Three Percent Fund" was administered by state agents located at the county level. First apportionments from this fund were made in 1821 . 
In 1836 in anticipation of funds to be dedicated by the Federal government to "the new states of the west" the Indiana General Assembly passed the Internal Improvement Act for the purpose of improving general transportation in Indiana. This Act called for the creation of the Internal Improvement Board, an agency which was to be authorized to negotiate loans and let contracts with funds being obtained through the sale of state bonds as well as the appropriation of state monies derived from 1 and taxes, to 17 s, and rents. Unfortunately, mainly as a result of mismanagement, inexperience and poor planning, this agency went bankrupt. It was dissolved and replaced by a Board of Public Works. This board also had little success and in 1842 the state government gave up on a state highway system and turned the responsibility for roads over to the counties.

The first major authority for local road financing came in 1877 when the county commissioners gained the authority to construct roads on petition of the major residential land owners, financed through property taxes and the sale of bonds. Four years earlier, cities and towns with increasing road problems gained authority to assess abutting properties and sell bonds to support urban road improvements.

With the inception and rapid growth of automobile usage, it quickly became apparent that local financing and management of the entire road system was inadequate. Also with increasing use of the automobile came the adoption of the "user" form of taxation, in 1913 the registration fee and 
in 1923 the motor fuel tax. Intially the registration fee was collected and distributed at the county level but with the expanding need for a statewide coordinated highway effort the state again took control of highway finance and administration. The final impetus leading to reinstatement of state control was the Federal Highway Act of 1916 providing for the allocation of federal aid for state highways, contingent on their being administered by a state highway agency. Accordingly in 1917 the Indiana State Highway Commission was formed with its first aim the construction of "farm to market" roads. Intially the financing of these roads was to be derived from the following sources:

1. Proceeds of the inheritance tax,

2. Grade Separation reimbursements from railroads,

3. General Fund appropriations for highways.

In 1919 a law was enacted calling for a state highway system to reach every county seat and every town over 5000 in population. This system was at its inception to be financed by a property tax, motor vehicle fees, and federal aid.

The early 1920's saw a rapid reversal in the sources of highway revenues in that user taxes rather than general taxes assumed the major role in the support of state highways. In 1920 user taxes in the form of the registration fee, contributed only 30 percent of total highway revenues. However, between 1920 and 1925 a two cent gasoline tax was added in 1923 , proceeds from the inheritance tax were rededicated to 
the general fund, and in 1925 the property tax was repealed. Thus by 1925 the user was supporting almost 100 percent of state highway construction.

In 1937 to simplif $y^{\prime}$ management of highway revenues the Motor Vehicle Highway Account was created to combine all user funds into one singie account; similarly all funds were distributed from this account among government levels, according to one distribution formula. The Motor Vehicle Highway Account is the fund to which highway user revenues are at present dedicated.

\section{Present Tax Structure}

Indiana presently obtains revenues for highways, roads, and streets from both the highway user and the general pub1ic. Figure 6 is a chart indicating the primary federal, state, and local revenue collection agencies, the taxes collected by each, and those available for highway improvement. User revenues are collected at the state and federal lever and then distributed to the local government units according to fixed distribution formulas. User revenues are collected mainly by three agencies:

1. The Department of Revenue

a. Motor Fuel Tax,

b. Dealer and Distributor licenses;

2. The Bureau of Motor Vehicles,

a. Vehicle Registration

b. Drivers licenses, 


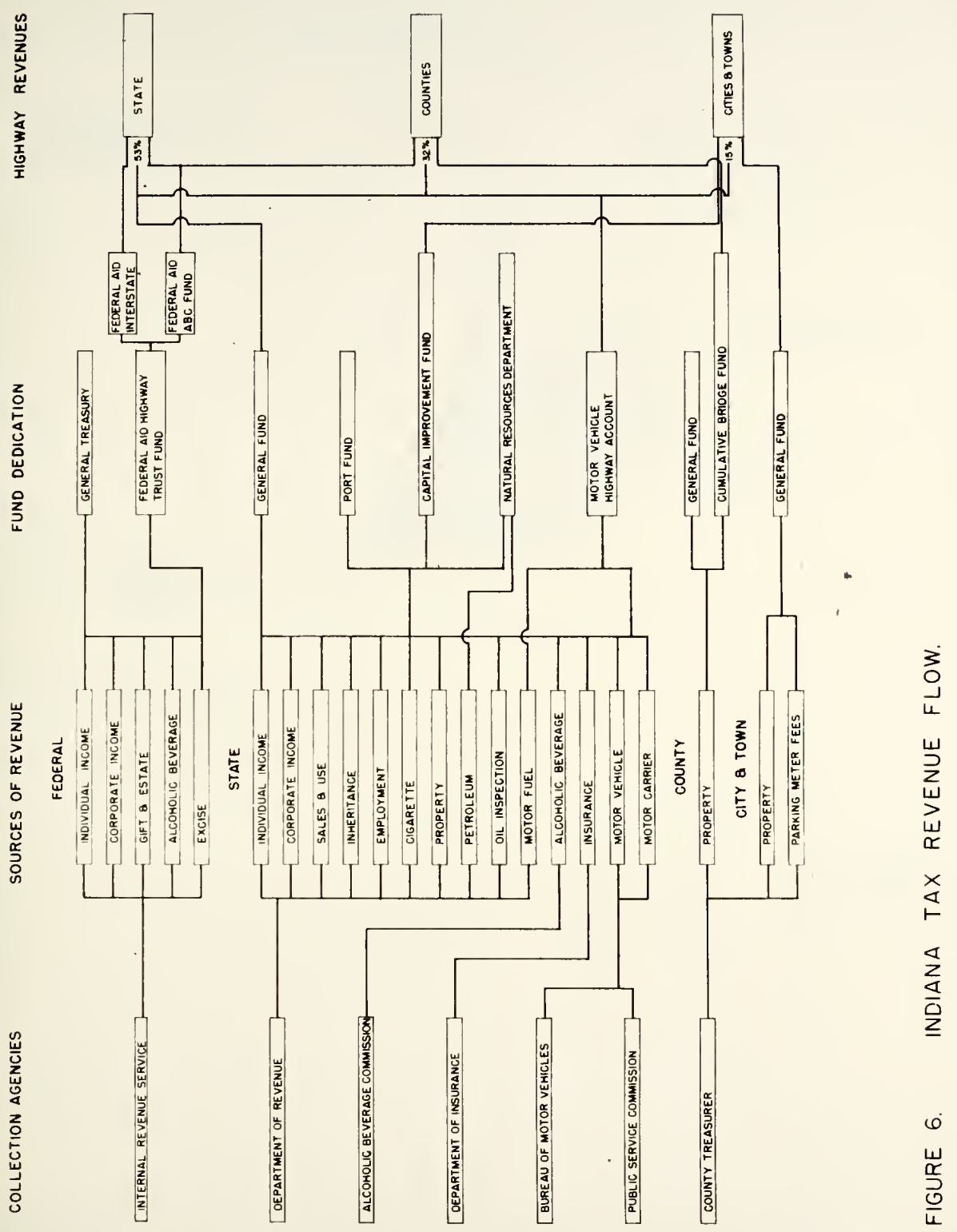




\section{$1.9 \%$ DRIVERS LICENSES, TITLE \& TRANSFERS, MISCELLANEOUS}

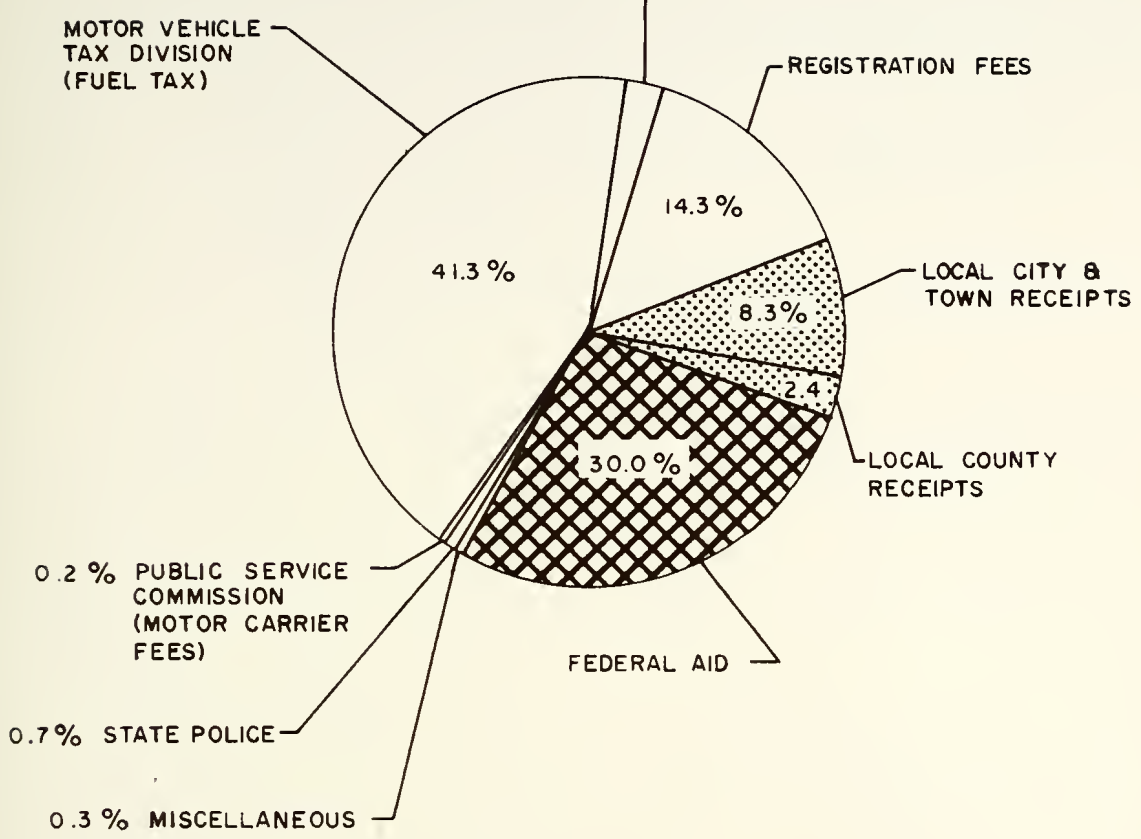

MOTOR VEHICLE HIGHWAY ACCOUNT

FEDERAL AID $\times \times \times \times \times \times 0$

LOCAL REVENUE

FOR THE YEAR

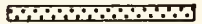

1966

FIGURE 7. 
C. Titles and Transfers;

3. Public Service Commission,

a. Motor Carrier Fees.

Additional funds collected at the state level are from:

1. The auditor of the State,

a. Motor vehcile highway civil penalities;

2. The General Fund,

a. 25 percent of the appropriation for state police.

At the county level highway revenues are derived from the property tax, specifically the Cumulative Bridge Fund and from apportionments from the Federal and State governments, Federal-Aid Secondary, and Motor Vehicle Highway Account Funds, respectively.

In 1966 of funds available for county roads, 83.2 percent were derived from the Motor Vehicle Highway Account, 11.3 percent from Cumulative Bridge Funds, and 5.5 percent from County F.A.S. funds.

In cities and towns, street revenues are derived primarily from the property tax, parking meter fees, and from apportionments from the M.V.H.A. Of funds available for cities and towns approximately 48 percent come from the M.V.H.A., 49 percent from $10 \mathrm{cal}$ revenues, and the remaining 3 percent from debt transactions. Figures $8-11$ indicate the breakdown of highway revenues from state, counties, and cities and towns since 1945 and 1950. 


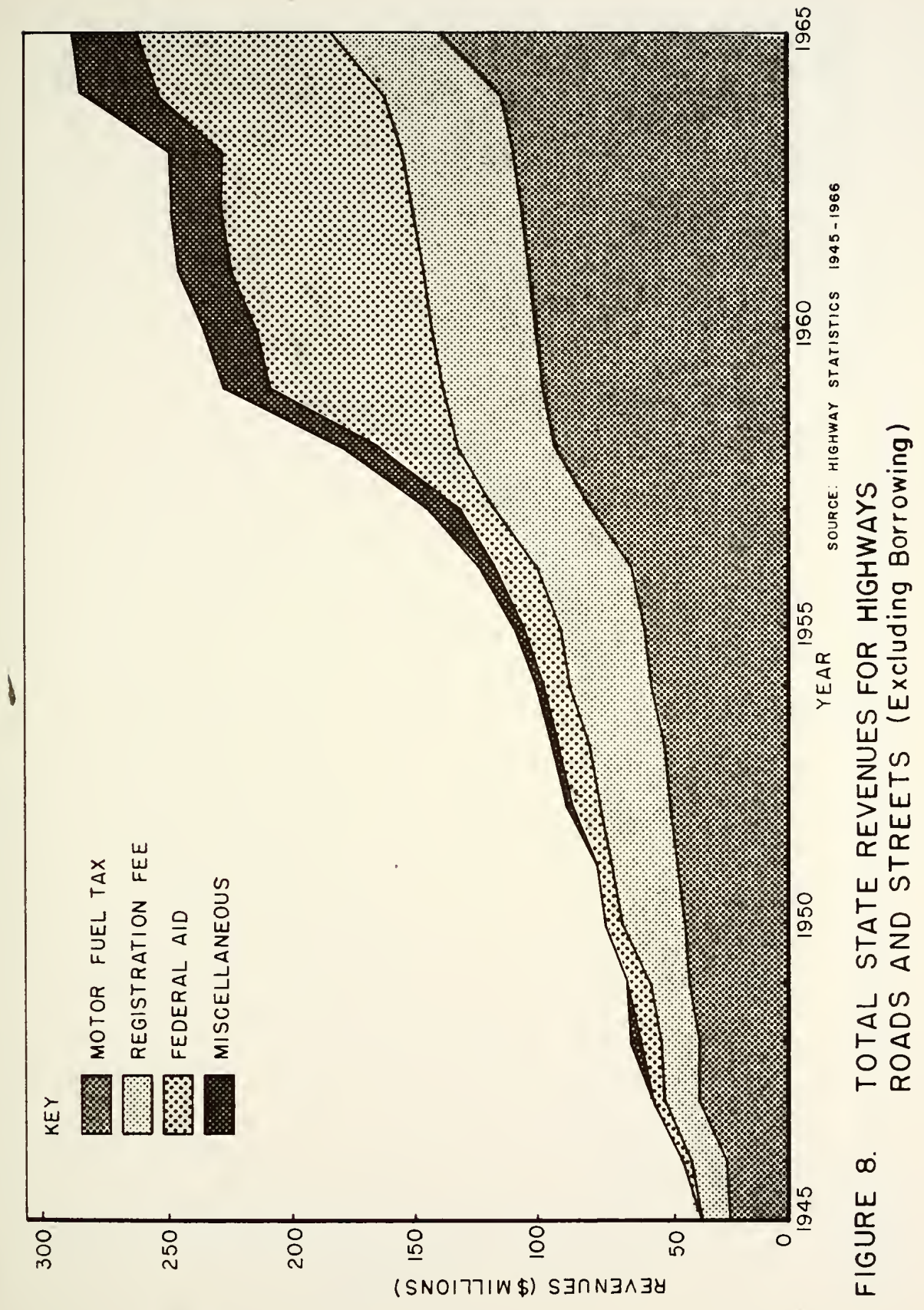




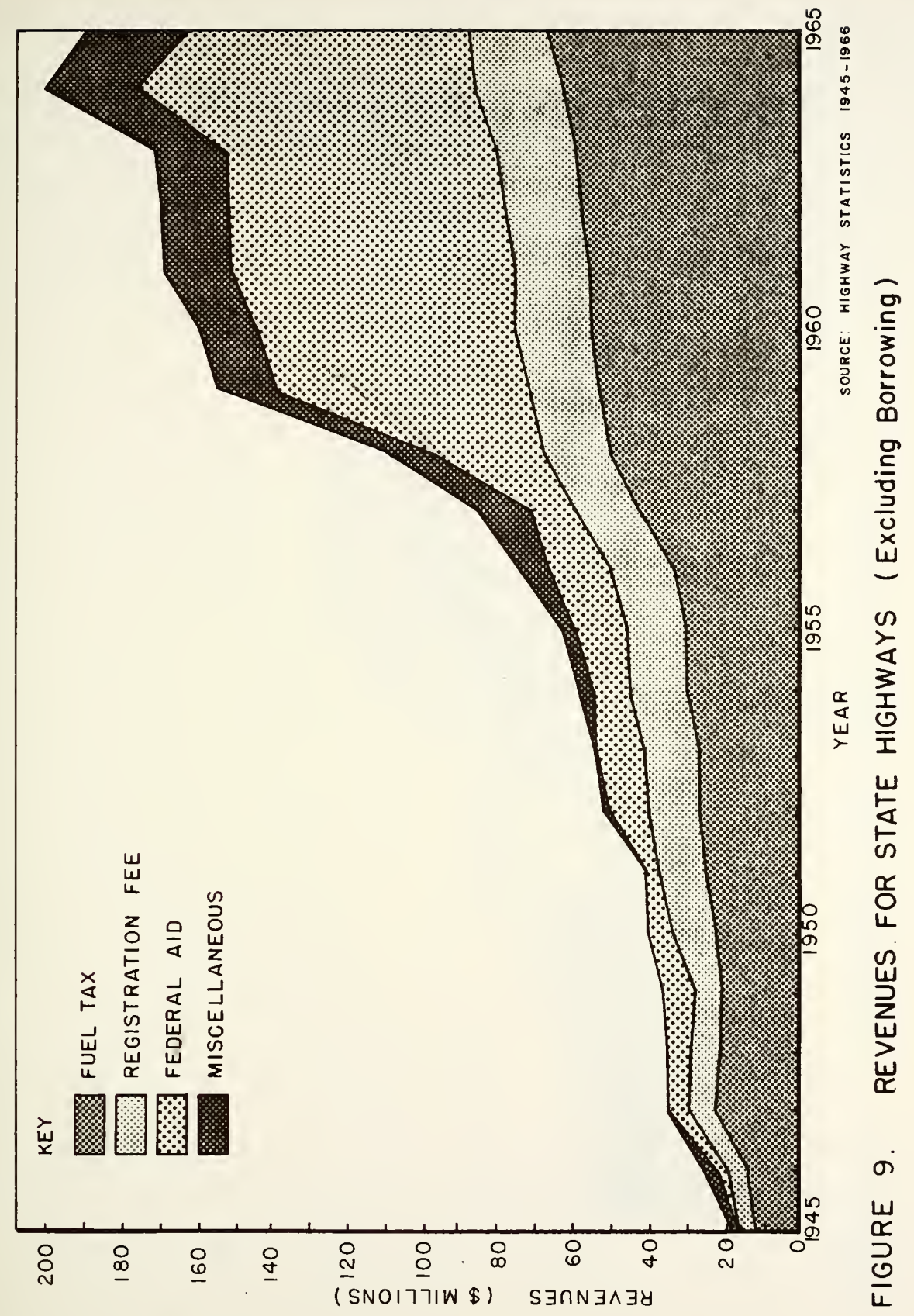




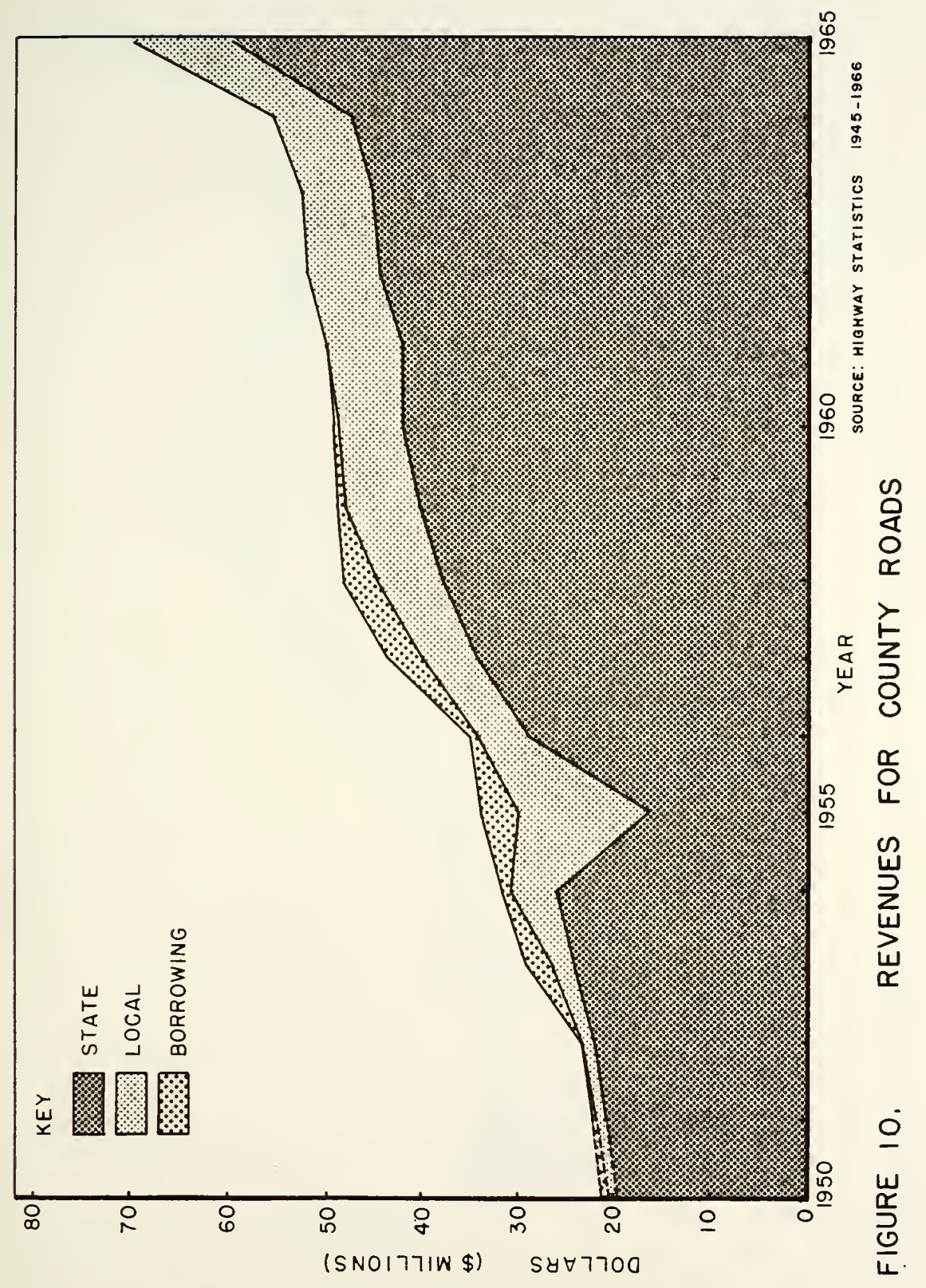




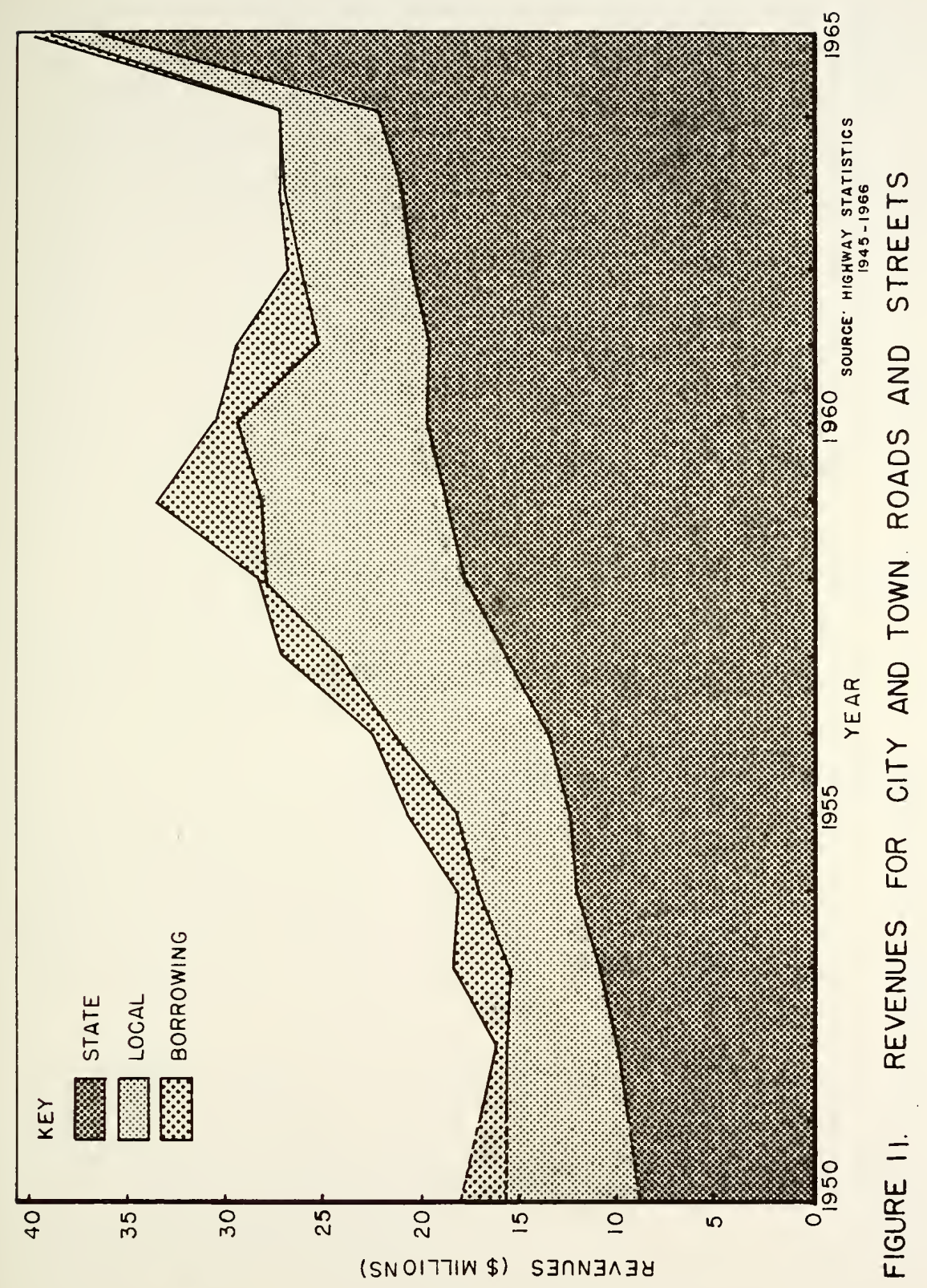




\section{Cost Responsibility of Users and Non-Users}

The Needs Study found that the users cost reponsibility for highways, roads, and streets was 64 percent of the total cost while the non-users share was 36 percent. The history of cost responsibility in the financing of highways in Indiana, however, has not followed such an allocation. In recent years, the actual division of funding has been about 88 percent user and 12 percent non-user or public. In these statements the user is defined as the motor vehicle user with user funds as those funds collected for use on the highway from fees on the vehicle or its use.

The allocation of cost responsibility by the Needs Study for the needs of 1966-1985 was by state, county and city highway, road, and street systems as follows:

\section{(In millions of dollars)}

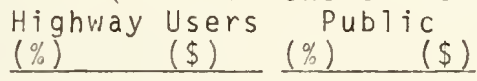

Total

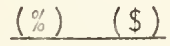

$\begin{array}{lllllllll}\text { State Highway System } & 87.6 & \$ 221 & 12.4 & \$ 31 & 100.0 & \$ 252\end{array}$ $\begin{array}{lllllll}\text { County Highway System } & 41.2 & 76 & 58.8 & 108 & 100.0 & 184\end{array}$ $\begin{array}{llrrrr}\text { City and Town Streets } 41.8 & 36 & 58.2 & 50 & 100.0 & \frac{86}{\$ 333} \\ & \$ 189 & \end{array}$

Current sources of revenue at current rates and current distribution of funds used for highways, roads, and streets are estimated to return the following annual average amounts for the 1966-1985 period: 
(In millions of dollars)

Highway Users Public

$(\%) \quad(\$)$

$(\%) \quad(\$)$

Total

$100.0 \quad \$ 189$

$0.0 \$ 0$

$(\%) \quad(\$)$

State Highway System

86.7

72

13.3

11

$100.0 \$ 189$

County Highway System

$\frac{35}{\$ 296}$

$44.4 \frac{28}{\$ 39}$

100.0

83

City and Town Streets 55.6

100.0

63

$\$ 335$

Comparing the last two listings of tabular data, it is clear that present sources of revenue are primarily user sources. Although the Needs Study shows heavy public responsibility for financing county roads and city streets, 88 percent of the funds for all systems come from user revenues. On the other hand, cities and town are utilizing public sources of revenue for over 44 percent of their total street funds.

Even though other studies support the findings of the Indiana Needs Study relative to the equitable cost responsibility assignment between the user and the public, the user in almost every state continues to pay a share greater than 64 percent. The reasons for this situation probably include that many other demands exist for public funds, a general philosophy exists that the user should pay, the ease of collecting from the user, and his willingness -- at least to this time - - to pay. The decision as to what the assignment of cost responsibility shall be in Indiana in the future -as it has been in the past -- rests with the Legislature. If additional funds from the public are to be used for highways, the Legislature must assign or at least authorize more 
funds from public sources of revenue for use on highways, roads, and streets.

Reality indicates that changing the assignment of cost responsibility for highways, roads, and streets from the current 88 percent user, 12 percent public to the recommended 64 percent user, 36 percent public may not be possible. Consequentiy Table 7 has been prepared. This table indicates the dollar responsibility for the users and the public for several assignments of cost responsibility.

The 75 percent user, 25 percent public assignment is shown because it is almost exactly half-way between current actual funding responsibility and that recommended by the Needs Study. 


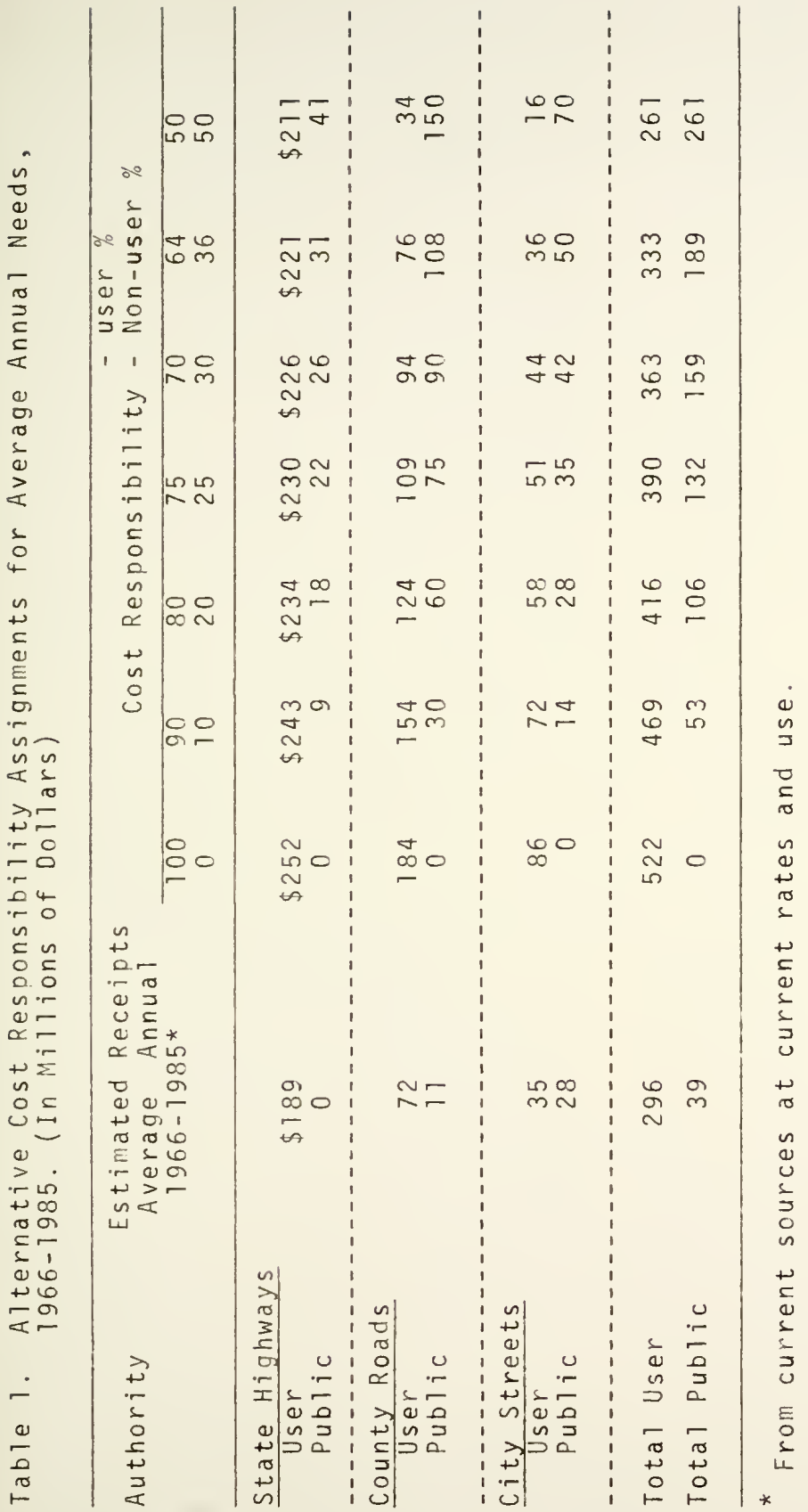


CHAPTER IV. REVENUE SOURCES FOR HIGHWAYS

As noted previously, Indiana is faced with a $\$ 186$ million average annual deficit over the next twenty years, if it desires to carry out the recommendations of the Needs Study. To eliminate or even to reduce this financial shortage, requires that steps be taken to increase highway receipts. Three avenues exist for the achievement of this objective: (1) divert funds from other government pursuits, (2) increase the levy of existing taxes used for highways, and (3) levy new taxes on the highway user and/or on public tax bases, to be earmarked for highway purposes. Of course, a combination of the three avenues might also be used.

Opposition from other government agencies, as well as for other reasons suggested in the previous section, will likely restrict recourse to the first alternative, diversion of funds used now by other areas of government spending. Nevertheless, some possible such sources were included in this study and are reported herein. The major sources of revenue investigated, however, fall under alternatives (2), and (3), existing and new taxes and their revenue producing potential.

A fourth available alternative to support implementation of the Needs Study recommendations is through the use of bonding. It must be noted, however, that borrowing would 
not eliminate the requirement for additional revenues, but would make possible implementation of the needed construction at an earlier date and spread payment for it over a period in excess of twenty years.

\section{Motor Fuel Tax}

Among the highway user taxes presently in use the motor fuel tax provides by far the greatest proportion of revenues. Motor fuel tax as generally applied, refers to gasoline as well as all "special fuels" such as diesel and liquified petroleum gases, propane and butane.

If the principle that highway users should pay for highways in proportion to the benefits received is accepted then the motor fuel consumption is an appropriate tax base. Benefits are derived both through the number of miles traveled and the gross operating weight while traveling, the latter applying primarily to the commercial carriers of goods. Fuel consumption varies in proportion to these criteria and thus the measure of benefits derived is assessed through the payment of a motor fuel tax.

It is primarily for the above reasons that all fifty states as well as the Federal government employ the motor fuel tax as the foundation of their highway taxation schedules.

Other factors which have lead to the general acceptance of the fuel tax by both the government and the public are: 
1. It is very easy and inexpensive to administer.

2. It is convenient for the user to pay.

3. It provides a stable continuing revenue source.

State taxes on motor fuel at the start of 1968 ranged from a low of 5 cents per gallon in four states to a high of 9 cents per gallon in one state, Washington [13]. Eleven states including Indiana imposed a 6 cent tax, five states a 6-1/2 cent tax, 26 states and the District of Columbia a 7 cent tax, two a 7-1/2 cent tax, and one state each an 8 cent and a 9 cent tax. The weighted average tax rate at the start of 1968 was 6.65 cents.

The present rate of 6 cents in Indiana was established in 1957 when the tax rate was increased from four to six cents. In the adjoining states to Indiana, Illinois increased its fuel tax from 5 cents to 6 cents in 1967; Michigan went from 6 cents to 7 cents on January I, 1968, while Ohio and Kentucky have had a 7 cent rate for several years. If one considered the Indiana tax of 6 cents today (1968) in terms of the 1957 value of the dollar, the present tax rate is about 5.1 cents per gallon, in other words an actual decrease of 15 percent in the tax rate. A tax rate of 7 cents today would be approximately equivalent in buying power to the 6 cent rate in 1957 .

Fuel consumption by private and commercial vehicles in Indiana increased 102 percent from 1.071 billion gallons in 1950 to 2.162 billion gallons in 1966. The projected increase from 1966 to 1985 is 55 percent of the 1966 use for 
a 1985 consumption of 3.365 billion gallons [3].

Gross receipts in 1966 from taxation of motor fuel amounted to $\$ 134,651,000$. After refunds of taxes on motor fuel purchased for other than highway uses, net receipts amounted to $\$ 127,762,000$. Adding an additional $\$ 1,705,000$ from distributors and dealers fees, inspection fees, fines, and penalities resulted in net receipts of $\$ 129,467,000$ [14].

At current rates expected net receipts from motor fuel taxes in 1985 will be $\$ 201,917,000$, or an average annual net revenue for the period 1966 to 1985 of $\$ 164,840,000$. An increase of 1 cent in the tax rate on motor fuel, i.e., an increase from 6 cents to 7 cents, is estimated to return an average annual revenue of $\$ 27,276,000$ for the period $1966-1985$.

Differential Taxes on Diesel and Other Special Fuel Though it is widely accepted that a tax on motor fuel is a good first approximation of highway use, there remains considerable controversy as to exactly how fuel consumption varies with respect to highway use and type of vehicle, type of service, and type of fuel. There are two main fuels in use today for motor vehicles, gasoline and diesel, with a third liquified petroleum gas, (mainly propane and butane), gaining in significance in recent years.

In 1967, eleven states Levied a fuel tax differential of one or more cents on fuels other than gasoline. Only four of these states imposed a higher than gasoline tax on 
L.P. gas. Some other states provided for higher registration fees for vehicles using fuel other than gasoline. The differential for diesel is considered warranted because of the lower fuel consumption of diesel engines for vehicles of the same size and weight (see Figure 12). Diesel engines because of their higher allowable compression ratios and thus higher thermal efficiency consume less fuel. Liquified petroleum gas, used in the standard gasoline engine by a simple conversion in the carburetor, has a slightly lower heat content but higher thermal efficiency than gasoline [15], thus fuel consumption is also lower than a similarly operated gas engine. Miles per gallon of L.P. gas is greater than gasoline but less than diesel; thus, differential taxation of these fuels is justified on this basis, though to a lesser extent than diesel. It would appear, then that if the fuel tax is to be assessed on miles of travel, a significantly higher rate is required for diesel fuel and a slightiy higher rate is required for liquified petroleum gas.

opponents to a tax differential however, argue that a higher tax tends to negate the fuel saving advantage and thus discourages the use of special fuels in those states imposing a higher tax. If this claim is true, states imposing an additional special fuel tax would be expected to experience a lower growth rate in diesel registrations than states which do not have such a tax. A comparison of 


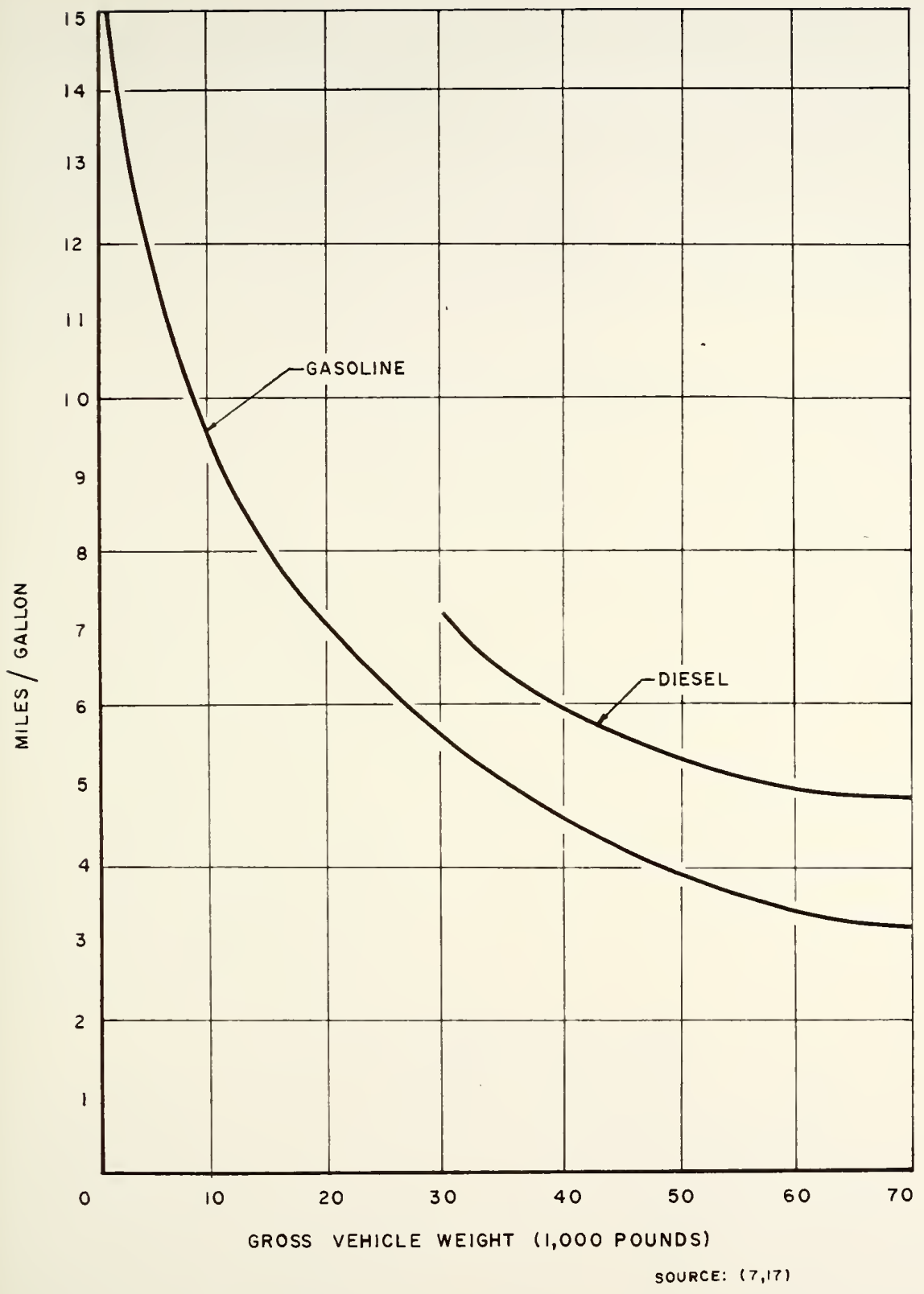

FIGURE 12. COMPARISON OF MOTOR FUEL CONSUMPTION RATES 
appropriate registrations for the years 1960 and 1966 as to growth of diesel registrations versus a tax differential revealed no statistical evidence to validate the claim that such a tax discouraged the use of diesel power units.

Tennessee in their study of the growth in motor fuel use between 1951 and 1954, gasoline versus special fuels, concurs with this conclusion [16].

Nevertheless, few states have imposed such a differential tax on special fuels and most such taxes are on diese? fuel. None of the four states adjacent to Indiana had a differential fuel tax in 1967. Special fuels constituted about 8 percent of the fuel used on Indiana highways in 1966. In 1961 , the percentage was 4.8 percent. For both years, these special fuels consisted mainly of diesel fuel.

If such a tax were imposed on special fuels, it is estimated that a 7 cent differential would provide an average annual revenue of $\$ 3,444,000$ between $1966-1985$, based on an anticipated increase in the use of these fuels in relation to gasoline.

\section{Motor Vehicle Registration Fees}

Registration fees were the earliest form of motor vehicle taxation. Initialiy the fees were imposed as a regulatory measure; however, it soon became apparent that they were a lucrative revenue source. From this beginning has developed the complicated graduated fee schedule which exists today. A registration fee is basically an annual 
charge on motor vehicles licensing them to operate on the public street system. In addition, the concern for equity in highway user taxation has resulted in using the registration fee to offset any inequities of the motor fuel tax, in that registration. fee scales are usually graduated on the basis of vehicle size or weight.

By allocating the burden of taxation through registration fees on the basis of vehicle size, weight, classification, and/or miles traveled, a second step is taken toward making each vehicle "pay its own way." Though the principle of assessment of registration fees is similar for all vehicle classifications, it is useful to consider passenger automobiles and trucks separately.

\section{Passenger Vehicles}

Through the years, passenger vehicles have been registered according to age, size, weight, horsepower, type of fuel, and flat fee. Many of these methods remain today. Table 2 indicates the registration fee levy as it existed in 1966 throughout the United States.

Indiana is among the twenty-three states levying a flat registration fee. The Indiana rate is $\$ 12.00$ per vehicle. The predominance of flat fee and weight registration is in recognition of the fact that weight is a variable among different automobiles affecting roadway cost. Those states levying a simple flat fee have made the further simplifying assumption that the weight range of automobiles 
Table 2. 1966 Passenger Vehicle Registration Requirements in the United States.

\begin{tabular}{lcc} 
Method of Assessment & $\begin{array}{c}\text { Number } \\
\text { of } \\
\text { States }\end{array}$ & $\begin{array}{c}\text { Range in } \\
\text { Assess Fee } \\
\text { (dollars) }\end{array}$ \\
\hline Age & 1 & $7.50-17.50$ \\
Age and Value & 1 & $16.51-82.70$ \\
Age and Weight & 2 & $5.00-46.50$ \\
Weight and Value & 1 & $10.00-71.00$ \\
Weight & 20 & $5.00-66.50$ \\
Weight and Flat Fee & 1 & $7.00-20.00$ \\
Flat Fee & 23 & $5.00-32.00$ \\
Horse Power & 2 & $8.00-24.00$
\end{tabular}

Source: [14]

is insignificant in influencing roadway costs. The administrative simplicity of the flat fee also tends to outweigh the greater accuracy of a weight fee. The average registration fee among all states including the District of Columbia at the end of 1966 was about $\$ 15.70$; thus, Indiana in terms of registration fee alone is charging well below the national average.

At least nine states increased their registration fees during 1967. Two of these were Illinois and Michigan. Illinois increased its registration fees for most passenger 
cars to $\$ 24$ from $\$ 22.50$. The Michigan fee for passenger cars increased to 55 cents per 100 pounds weight from 35 cents. The 0 hio and Kentucky registration fees remained at $\$ 10$ and $\$ 4.50$ annually, respectively.

If a $\$ 1.00$ increase were made in automodile registration fee, it is estimated that the 1966-1985 average annual revenue increase would be $\$ 2,496,000$. An increase per automobile to a $\$ 16$ fee just about the national average in 1968 , would increase annual average revenues by $\$ 9,982,000$. These estimates are based on an anticipated automobile registration increase from 2,069,685 in 1966 to $3,164,000$ in 1985 . Based on the existing registration fee of $\$ 12.00$, the average annual revenue anticipated $1966-1985$ is $\$ 29,948,000$.

\section{Trucks}

The establishment of registration fees on trucks is complicated by two factors: first, there is considerable variation in truck size and weight creating problems of what rate for what weight, and second most trucks are used commercially and are thus in competition with other transportation modes. The need for trucks to pay their fult share of the cost of providing highways must, therefore be considered. A thorough discussion of cost allocation among types of users is beyond the scope of this report. The Needs Study report includes a discussion of its study of this matter. 


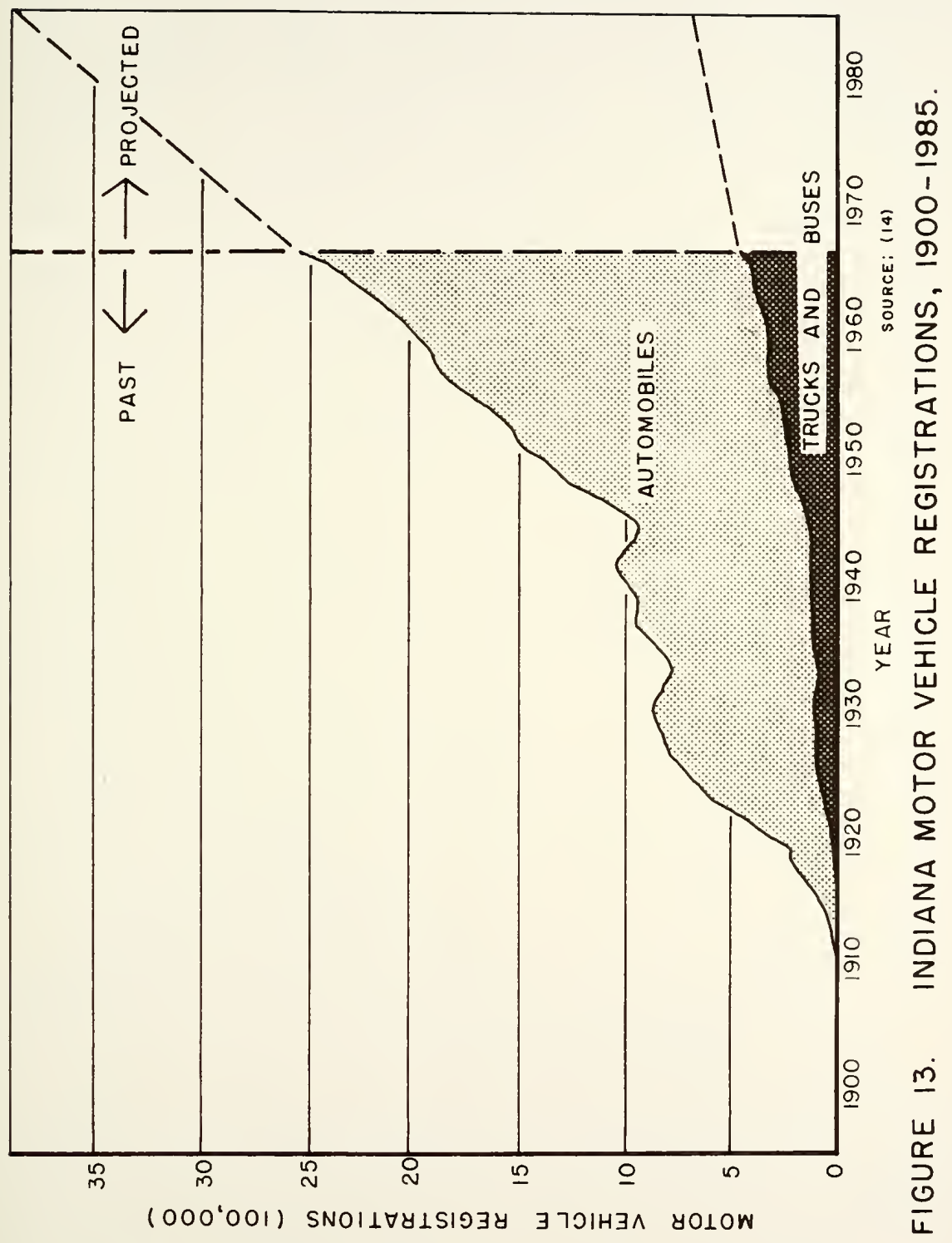


The most commonly used basis for calculating truck registration fees are gross weight and empty weight. Some states, however, base their calculations on such other factors as capacity, age, and number of axles. If weight is accepted as the most equitable measure of cost occasioned, gross operating weight is probably the most correct tax base. However, since actual gross operating weight fluctuates considerably from trip to trip, many states have accepted the registered gross weight as the next best choice. This creates some hardship on less than maximum weight haulers but their desire to optimize tends to minimize the occurrence of this situation.

Indiana is among the majority of states in which the registration fee is assessed on the basis of registered gross weight. Figure 14 portrays Indiana's registration fee schedule in relation to the national average for registration based on gross operating weight. It is evident that in all weight categories, Indiana is below the national average, especially in the heavy vehicle classifications.

For the most part the differences in the heavy weight categories are due to the broad upper weight categories used for Indiana trucks. The top gross weight classification used in 1967 was for trucks 34,000 1bs. and over, and for tractor-semi-trailer combinations 52,000 1bs. and over. In the same year there were 6,278 trucks and 22,577 tractorsemi-trailers in these weight categories. The 22,577 


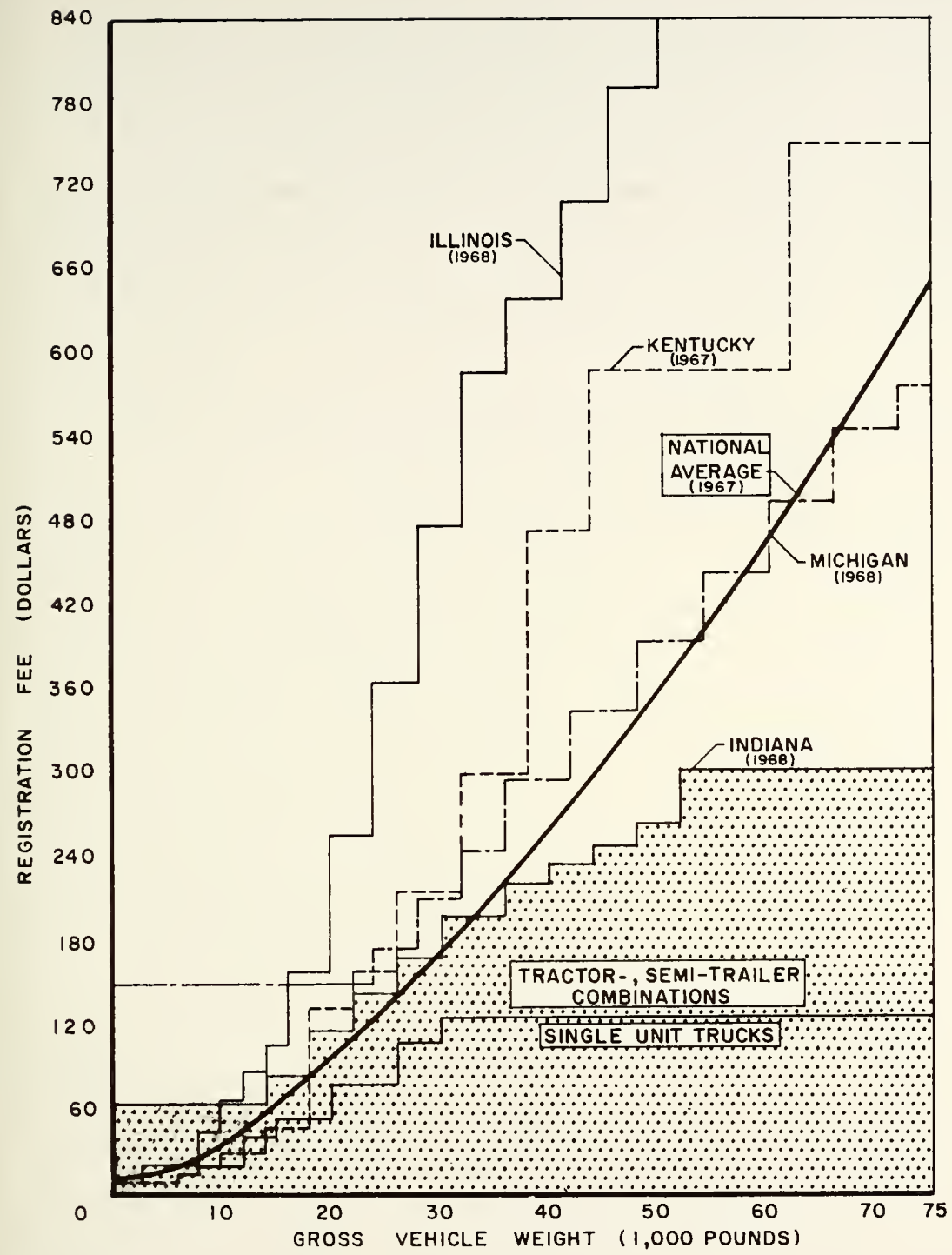

FIGURE 14. REGISTRATION FEE SCHEDULE FOR MOTOR CARRIERS. 
tractor-semi-trailers constituted 72 percent of the total of 31,288 such units registered for that year.

As the allowable load limit in Indiana is $72,0001 \mathrm{bs}$. gross, some partitioning of these top categories would appear justified. Michigan, for example which allows loading up to 130,000 1bs. has graduated weight classifications up to this weight.

Registration fees for trucks were increased in 1967 in Illinois to a range of $\$ 12$ for a 3,000 pounds or less truck to $\$ 1210$ for a combination vehicle (tractor and semitrailer drawing one trailer). Michigan, also in 1967, increased its registration fees for trucks to a range of $\$ 150$ for 8,000 pounds gross weight to $\$ 980$ for over 130,00 pounds gross weight. Ohio has had a registration fee ranging from $\$ 0.85$ to $\$ 3.25$ per 100 pounds net weight for several years. Kentucky's current fees range from $\$ 10$ to $\$ 750$ and were made effective in 1967.

It has been estimated that an across the board 10 percent increase in truck registration fees would provide a $1966-1985$ average annual revenue increase of $\$ 2,461,000$. This estimate is based on a 1985 projection of 654,000 trucks; 50,000 truck-tractors, 129,000 trailers, and 87,000 semitrailers. Such an increase would be a $\$ 1.00$ increase for light trucks to a $\$ 30.00$ increase for large tractor and semitrailer combinations. A considerable increase in truck fees could be made for some weight groups without exceeding the 
national average. For an increase to the national average, it is estimated that for the period 1966-1985, average annual truck registration fee revenues would be increased by $\$ 15,995,000$.

Comparison of Indiana registration fees with those of other states, however, must be considered with the personal property tax which Indiana, as we 11 as twenty other states, imposes on motor vehicles. A discussion of this property tax is included in a later section.

\section{$\frac{\text { Driver License, Title, Transfer, }}{\text { and Miscelianeous Fees }}$}

In Indiana as in all other states, an operator's license is required to operate a motor vehicle. Though basically a regulatory control, the operator's license fee does provide a small but significant revenue source. At present, Indiana's motor vehicle operator's licenses are divided into three categories:

Number issued 1966

$$
141,525
$$

$1,508,890$

206,325
Classification

Learner Permit

Operator License

Chauffeur License 1 year

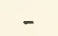

Term of

Issuance

2 years

$\$ 1.00$

$1,856,740$

A learner's permit is required in all but three states. of those states requiring a permit, forty-two require payment of a fee ranging from $\$ 0.50$ to $\$ 5.50$. Of those states 
requiring a fee payment, the average fee is $\$ 2.15$.

Operator's licenses are required in all states with a term of one to five years, and a fee ranging from $\$ 1.00$ for five years to $\$ 13.00$ for two years. The average license fee for one year is $\$ 1.85$.

Forty-two states provide for chauffeur's licenses for commercially operated vehicles. The fee ranges from a low of $\$ 1.00$ for three years to a high of $\$ 13.00$ for two years. The average license fee for one year is $\$ 3.00$.

From the above it can be seen that Indiana's driver license fees are well below the national average. The I linois operator's license fee is $\$ 3.00$ for three years. Michigan's fee is $\$ 2.50$ for three years; 0hio's is $\$ 1.00$ for three years, and Kentucky's is $\$ 2.00$ for 2 years.

In 1966 it is estimated that there were a total of $2,752,313$ licenses in force. This is a ratio of 1.09 drivers per registered vehicle. The 1965 ratio of potential drivers (persons 15 years of age and over) to vehicles was 1.39 . By 1985, when 4,434,000 potential drivers and 3,868,000-vehicles are anticipated the projected ratio is 1.15 potential drivers per vehicle. It is estimated that by 1985 there will be approximately 3,117,000 drivers licenses in force. When receipts from titles, transfers, and miscellaneous items are included with operator 1 icense revenues the total revenue for 1966 was $\$ 5,524,500$. The estimated total revenue from these sources is estimated to be $\$ 8,294,000$ in 
1985. It is estimated that an increase of $\$ 1.00$ in operator's and chauffeurs license fees would provide an average annual revenue of $\$ 1,675,000$ between 1966 and 1985 .

\section{Motor Carrier Fees}

In addition to registration fees, motor carrier fees are collected in Indiana by the Public Service Commission on vehicles which operate as common or contract carriers of passengers or property. The fees are $\$ 12$ for trucks and buses and $\$ 24$ for tractors. These fees apply to both intrastate and interstate operation (subject to reciprocity agreements). In addition to the above, each company when making application for registration, extension of route, or transfer, must pay the appropriate fee: $\$ 50$ plus $\$ 10.00$ notice of publication fee for change of name not involving ownership change; and for Interstate operation, a $\$ 25$ fee for registration of interstate authority not requiring public hearing. The revenue collected by the Public service Commission in 1965 amounted to $\$ 702,406$ and is expected to increase to $\$ 1,333,000$ in 1985. Each 10 percent increase in Motor Carriers fees would provide an average annual revenue $1966-1985$ of $\$ 104,000$.

\section{Parking Revenues}

Parking revenues only are significant in urban areas where the parking demand is high and the supply limited. As a consequence of this supply-demand relationship, most urban 
areas impose a charge for parking either by means of meters or, in larger cities, where street congestion demands street usage be for traffic, at offstreet parking facilities.

Revenues from parking provided an average of 8 percent of the total local receipts of urban areas for street and traffic purposes during the period 1960-1964 [3].

What are the potentialities of this revenue source for financing street needs in the future? Indiana statutes (Burn's Indiana Statutes 48-521) states:

Subject to any valid contractual obligation or covenant entered into prior to the effective date of this act, the several cities and towns shall provide by ordinance, that all license fees, when collected from such mechanical parking devices, shall be deposited with the treasurer or clerk treasurer of their respective cities or towns to the credit of any such city or town, but in a special fund from which disbursements shall be made only under the orders of the board of public works or the entity performing the functions of such board for the city or the board of trustees for the town and disbursements shall be made for no other purpose than:

a) Payment of the purchase price, rental fees, and cost of installation of the mechanical parking devices.

b) Payment of the cost of maintenance, operation, repair and all other incidental costs and expenses in the operation of the mechanical parking devices, including the cost of clerk and bookkeeping.

c) Payment of the cost of traffic signal devices used in the city or town and also repair and maintenance of any of the public streets including curbs and sidewalks, and highways where the mechanical parking devices are in use, and all streets connected therewith in the city or town; and 
d) For the purpose of acquiring by lease or purchase suitable land for off-street parking facilities; for the payment of principle and interest on bonds issued to acquire parking facilities and devices; for the improvement and maintenance of 1 and for parking purposes; and for the purchase, installation, and maintenance of mechanical parking devices on the 1and: Provided, that the city or town may either operate or lease the off-street parking facilities;

e) Payment of the costs of purchase, maintenance, operation, repair, and all other incident costs of providing approved school crossing protective facilities.

Thus according to section c) funds can be used on streets where parking devices are used and on streets connected therewith. In 1965, the total receipts from parking fees in Indiana amounted to $\$ 3,597,000$. Of this total, only $\$ 303,000$ or less than 10 percent was spent on the streets. The remainder was primarily used for the parking function in the form of capital outlays, maintenance, operation and administration [14].

With the increasing demand for more offstreet parking facilities as the need for full traffic use of the streets increases, it is probable that in the next twenty years parking funds used for street purpose will decrease from the 1965 total of about $\$ 300,000$.

As a result, revenues from parking facilities will probably not be significant for the support of streets and highways during the 1966-1985 period and no additional revenue is estimated to be available from this source. 


\section{$\underline{T 011 \mathrm{~s}}$}

Following World War II, the tremendous backlog of highway improvement needs and the rapidly expanding demand for travel necessitated the immediate construction of major highway improvements. At that time, the only means of financing these monumental needs for major highways was the development of toll roads. By 1959 , total toll road mileage in the United States exceeded 3,200 miles. Forty states have incurred highway revenue debt obligations at some time in their history.

Toll road development reached its peak in 1954 when more than 52 billion in toll road bonds were sold [18]. After the Highway Revenue Act of 1956, with its promise of 90 percent federal financing for the Interstate system, most state officials were hesitant to continue toll road development. However, in recent years there has been a resurgence of interest in the toll road principle [19]. Many medium to high demand corridors are not included on the 41,000 mile Interstate System. These facilities typically are needed now and state authorities are unable to wait for possible future extensions to the Interstate system. For this and other reasons state officials are reassessing their position with regards to toll financing.

When considering the feasibility of a possible toll route, it must be ascertained whether the potential route will attract sufficient traffic, to pay the tolls necessary 
for the retirement of the debt incurred in the facilities construction and operation. If this problem were as easily solved as stated, there would be no risk in toll road financing. However, the questions of predicting future traffic growth within a corridor, the portion of this traffic willing to pay a toll and the amount of the toll which they will pay, leads to the necessity for carefully conducted feasibility studies wherever such routes are considered.

\section{Tol1 Road Advantages}

1. Toll road financing makes it possible to obtain funds for timely construction of certain high-cost, high priority facilities, despite legal and financial obstacles to their construction.

2. Toll roads provide immediate benefits to the user at the time he pays for them, as opposed to payas-you-go financing where a user must pay for a facility in advance of using it.

3. Toll roads charge on $l y$ those who use and thus benefit from the facility.

\section{Tol1 Road Disadvantages}

1. The toll road is not a panacea for all pressing highway needs; only a few long haul, high volume routes are suitable for toll roads. These are usually intercity corridors. 
2. Access and egress must be limited to high volume locations because of the high cost of constructing and operating toll collection facilities.

3. The initial construction costs are generally higher than for free roads as a result of the more complicated interchanges, the toll collection facilities, and the need for complete access control.

4. The use of revenue bonds for toll roads leads to higher financing costs than for government backed bonds $[18,20]$.

\section{Financing Tol1 Roads}

Though a more general discussion of borrowing for highways will be presented later, a brief description of financing toll roads is presented here.

Revenue bonds, that is obligations issued for specific facilities and secured solely by a pledge of the earnings of that facility, are used for financing almost all toll facilities. Because of the somewhat greater risk, interest rates on revenue bonds have tended to run between $1-1 / 4$ to 1-1/2 percent higher than on general obligation bonds. Tol revenue obligations are usually issued as term bonds; that is they mature on a flxed future date and are redeemed from the accumulation of a sinking fund. In the past these terms have ranged from 10 to 50 years; recentiy most bond issues have been for terms of 35 to 40 years. Generally revenues 
from toll facilities must be sufficient to pay all operating and maintenance costs of the facility as well as the cost of debt service.

To improve the feasibility of certain routes some states have assumed a portion of the costs of the toll facility. In Kentucky for exampie, the state assumes responsibility for the cost of operating, maintaining, and repairing certain toll facilities, permitting all toll revenues to be applied to debt service. Such sharing agreements appear justified to some, since the states also receive revenues from the toll road user in the form of motor fuel use tax and other user fees.

Toll facilities are generally administered by semjautonomous bodies which control and operate the facility for the state. These bodies, generally referred to as toll road authorities or commissions, are responsible for floating the necessary bonds for financing, letting contracts, and administering and operating the facility or facilities under their jurisdiction.

The higher interest rates necessitated by revenue bond financing have given rise to the suggestion that where possible other less costly forms of debt, such as general or limited obligation bonds should be used. Though these devices place the security of the government body behind the bond issue, the benefits in lower interest charges may be well worth the risk. In Massachusetts for example it has 
been estimated that savings in financing costs of 38 percent would have been realized if general obligation bonds were used instead of revenue bonds [21].

The above is not intended to preclude the use of revenue bonding or toll roads, but merely points out that if borrowing is considered, the device selected should be that which most economically serves the public interest, not simply that which places the least responsibility on the government.

\section{Double Taxation Issue}

One question which usually arises in a discussion of toll roads is the issue of double taxation. It is argued that the user, in addition to the standard taxes which he pays, must also pay a charge for using a toll route. This argument is considerably weakened by two factors: First there is generally a free road paralleling the toll facility which the operator may use without a toll, and second toll roads are generally additions to the system of highways which without tolls likely would not exist. The tolls pay for the facilities and in no way divert general highway user revenues away from "free" facilities.

It might also be pointed out that the toll paid by the user is a measure of the benefits which he receives from using the toll facility in the form of time and fuel savings, comfort, and conveniences, as opposed to an alternative free route. In a study conducted on fourteen sections of toll roads in the United Sates of the reasons a driver selected 
a toll route as opposed to parallel free routes, it was found that the toll road was used for the following reasons [22]:

Reason Given

Time Saving

Safety

Comfort

Lower cost

\section{Percent}

$71-84$

$1-7$

21

$0-1$

Only 13 percent of the parallel free road users said they did not use the toll roads because of cost. In light of the relatively high cost per mile to the toll road user in addition to his normal operating costs (more than 7 cent permile), this is a significant finding.

\section{Indiana Toll Facilities}

Though toll financing has had limited application in Indiana there are two toll financing authorities; the Indiana Tol1 Bridge Commission with authority over the Wabash Memorial, Brandenberg-Maukport and Hawesville-Cannelton Bridges, the latter two opened in 1966; and The Indiana Toll Road Commision for the operation of the 156.9 mile Indiana Toli Road opened in 1956. Revenues to the Bridge Commission in 7.966 amounted to $\$ 271,000$ from tolls and $\$ 263,000$ from income on investments. The Indiana Toll Road Commision received for the same year $\$ 15,723,000$ from tol1s, $\$ 1,546,000$ from income on investments, $\$ 2,498,000$ from concessions and 
$\$ 228,000$ from miscellaneous receipts [14].

The Indiana Toll Road is the only toll road facility in the state of Indiana. The 156.9 mile route was financed through the sale in 1954 of $\$ 280 \mathrm{million}$ revenue bond issue at par 3-1/2 percent interest to mature in 40 years.

The success of the Toll Road can partially be attributed to the fact that it connects with high level limited access facilities at both east and west extremities. It is also a part of the Interstate Highway system. Since its opening in 1956, the total number of vehicles using the toll road has increased from 446,133 to $12,964,735$ in 1967, with a total vehicle mileage in that year of over 666 million miles. This is 1.6 percent of the total mileage traveled within the state.

A criticism often stated concerning toli roads is the high cost of toll collection. The Indiana Toll commission's experience has been that toll collection costs have averaged 6.6 percent of toll receipts, a percentage only slightly higher than the percentage of total receipts required for collection of state administered road user fees.

Indications are that if travel trends continue as predicted the Toll Road Commission will have no difficulty in meeting its debt requirement commitment, making the Indiana Toll Road a financial success. It is interesting to note the value which motorists using the toll road place on the improved service provided. A typical passenger vehicle 
traveling the full length of the toll facility pays $\$ 2.80$ or over 1.75 cents per mile. This is equivalent to paying approximately 22 cents additional tax per gallon of motor fuel, a tax which incidently would return revenues three times those required for the unfunded highway needs of the next 20 years. Similarly a four axle commercial vehicle pays an undiscounted toll of $\$ 6.15$, or approximately 4 cents per mile.

If we assume that most motorists are aware of the relative high cost of using a toll route, it would appear that they are willing to pay for a high level of motoring service.

\section{The Future of Tol1 Roads}

Though interest in toll roads has been somewhat revived in recent years, it is unlikely that this financial device will ever again gain the significance it achieved in the early and middle $1950^{\prime} \mathrm{s}$. As discussed earlier a primary requirement for the building of a toll road is a high volume, long haul corridor. With the completion of the 4l,000 miles of the Interstate Highway system, it may be assumed that the majority of these corridors will have been served. Certainly there are high density corridors as yet unserved by Interstate Routes and these deserve consideration; however, great care must be taken to ensure that the competition of a nearby parallel free road will not be so great as to discourage use of a more direct but more costly toll route.

Because of this free road competition many high demand corridors, though badiy in need of improvement, are only 
partially feasible. One answer to this problem is the partial financing of a facility by means of tolls. Kentucky, as noted earlier, has several toll facilities upon which the tolls collected are used only for debt retirement while state funds are used to operate and maintain the facilities. Administrators tends to be in agreement that the toll device has not, as a result of the Interstate Highway system, lost its usefulness. However, it appears that caution, as well as some revised thinking on the idea of partial financing, must be used in the consideration of future toll road proposals.

\section{Congestion Tol1s}

In addition to the use of the toll road device to finance high volume intercity corridors or major river crossings, economists in increasing numbers are supporting the "efficiency" or congestion toll principle as a possible solution to urban transportation problems. In chapter II the idea of a congestion toll was introduced. It will be expanded upon in this section. Urban freeways, because of their extremely high cost per mile of construction (\$1-12 million per urban lane mile versus $\$ 300,000$ per rural 1 ane mile), [23], are absorbing increasing shares of Federal and State monies for highway construction. As rapidly as new facilities are built or cld ones improved, they are loaded to capacity with additional vehicles. Present efforts are directed almost entirely toward supplying more freeway lanes 
to meet the demand; there must, however, be some limit as to the supply which can be offered. Freeway construction within the urban area cannot continue forever unless the land uses which freeways are intended to serve are obliterated.

A basic principle of supply and demand theory is that when long-run demand exceeds supply, the price is too low. It is acknowledged that transportation because of its benefits to the public as well as to the user cannot be considered strictly as a supply and demand situation in the commodities market. However, a point may be reached where the marginal return to the economy by an additional freeway is at a low level. This point, it would appear, is being approached in some of today's urban centers. The efficiency or congestion toll, by charging a user according to some measure of the benefit he receives according to location and time, might be the use control which would bring equilibrium to this supply-demand relationship.

Some economists suggest that modern circumstances require a revision of pricing policies. Instead of earning revenue just to build more roads, taxes or tolis should also achieve optimum utilization of the existing highway system by controlling and directing the volume of use [24]. With the efficiency toll principle, the rate for the use of a facility would be set equal to what was believed to be the value of the marginal benefit produced by removing a user. Those who felt their loss by being diverted to be greater than the toll would pay the price. In this way, a toll system could 
eventually be established which would maintain a desired level of service on a toll facility at all times and avoid congestion breakdown.

An efficiency toll system could also serve to spread demand more evenly throughout the highway system by charging high tolls on high demand facilities and lower or no tolis on low demand facilities. To spread demand more uniformly in time, (peaking of travel demand is one of the major urban transportation problems), high tolls could be charged in peak hours and reduced in off-peak hours. The technology for initiating an efficiency toll system is not as yet available. However, several schemes have been suggested which may become feasible in the near future [25].

If the efficiency toll principle is vigorousiy supported on one side, it is just as vigorously criticized on another. Critics object on several bases $[23,26]$ :

1. Public opposition to paying for a system which was formerly "free" would prevent imposition.

2. Motorists are already paying their fair share of the cost of highways.

3. Transportation, because of its generat public benefit, can never be considered as a supply-demand problem.

4. A toll system would destroy the downtown by forcing business to move to areas where transportation was less costly. 
5. Establishing the toll rate to achieve the desired objective because of the complexity of travel demand, would be nearly impossible.

Many of these criticisms are likely valid to some degree, especially that of public opposition; however, it must be recalled that there was also considerable opposition to the first registration fee. Perhaps the congestion toll is not a ready solution to urban $i 115$, but it is at least a positive approach to the reduction of congestion in urban areas.

\section{Weight Distance Taxes}

The demand in recent years for equity in taxation among motor vehicles has fostered research into additional taxation forms over and above the gasoline use tax and registration fee. To impose total charges on larger vehicles more in keeping with the incremental costs occasioned in providing highway facilities to accommodate heavy vehic?es, several states have turned to a weight-distance tax sometimes referred to as a third structure tax. Such a tax which usually imposes charges on trucks in proportion to weight and mileage is an attempt to provide equitable taxation. It has been shown by research that the weight and number of applications of a load on a roadway are the most critical factors in its proper design.

The mileage tax has developed in four basic forms:

1. Mileage - - In some cases a fee is assessed only on miles of travel, irrespective of the weight of the vehicle. 
2. Ton-Mile -- Though this is likely the most theoretically accurate form, the difficulty of maintaining and enforcing the reporting of accurate records of gross tonnages on each trip, due to variable loading, has generally ruled out this means of assessment.

3. Registered Weight-Distance - - To eliminate the difficulties of ton-mile assessment, charges are levied based on the registered gross weight and the miles traveled.

4. Axle-Mile -- The number of axles on a vehicle generally vary with weight, thus axle-mile assessment is basically a simplification of the weight-distance levy.

Though the mileage tax is becoming more widely accepted, it has not gone uncontested. As they are the ones directly affected, the trucking industry has provided the greatest criticism. It is argued by them that such a tax disrupts reciprocity agreements, imposes an unreasonable burden on truckers, ieads to a general inflation of consumer prices, and is costly and difficult to administer. A testimony presented in 1964 in the Indiana Commission on State Tax and Financial Policy by the Indiana Motor Truck Association Inc., summarizes this criticism;

The imposition of such a tax would touch every business which uses truck transportation to obtain its raw materials and/or to distribute its finished product. The end result being increased prices for 
almost everything you eat, wear or use to be borne by the ultimate consumer...

A regressive type of tax applied only to the trucking industry through implementation of a so-called "ton-mile," "axle-mile" or weight-distance tax would create an unbearable inequity between the trucking industry and other forms of transportation as well as other taxpayers in Indiana.

The testimony goes on to state that it has estimated the cost of collection of such a tax to be approximately 12 percent of receipts [27].

The opposite viewpoint has been well stated by Stanley J. Bowers, Tax Commissioner of Ohio in his defense of the axle mile tax. He argues;

I can state unequivocally based on 23 years experience in tax administration in ohio, that the problems we have encountered in administering the ohio axlemile tax law during the past three years of its operation are no different in kind or degree from problems arising in conjunction with other forms of taxation...

He continues by discussing the axle-mile tax under the following headings:

Reciprocity - At the time of initial enactment of the tax he indicates that some states did not impose retaliatory charges against ohio truckers. As a result some truckers did leave the state. However, most of the retaliatory charges have now been removed and there seems to be no long term reduction in truck registrations.

Administration and Enforcement - - The primary problem with this form of taxation is obtaining compliance with 
the law since it is nearly impossible to employ siffficient staff to adequately audit truckers records. Cost of Administration - - Bowers has estimated that the cost of administering the ohio axle-mile tax is approximately 4-5 percent of total receipts. The cost of administering the New York weight-distance tax has been estimated at 9 percent and the 0regon weight-distance tax at 4.5 percent. Costs to Truckers -- There should be only slight costs incurred by the truckers since most maintain mileage records as an integral part of their operations [28]. The wide disagreement between administrators and administered indicates the scope of the problems facing a state planning to impose a new third structure tax.

Though the mileage tax has encountered considerable opposition, sixteen states and the District of Columbia have elected to impose such a tax on passenger carriers, property carriers or both. Table 3 suggests the form which these taxes had assumed by 1966 and the revenues obtained. It is of interest to note that in several states the mileage tax is imposed only on out of state operators who use in state highways but do not pay the usual in state fees. Michigan repealed its mileage tax effective January 1, 1967, and substituted an annual fee of $\$ 50$ per self propelled common and contract carrier. 


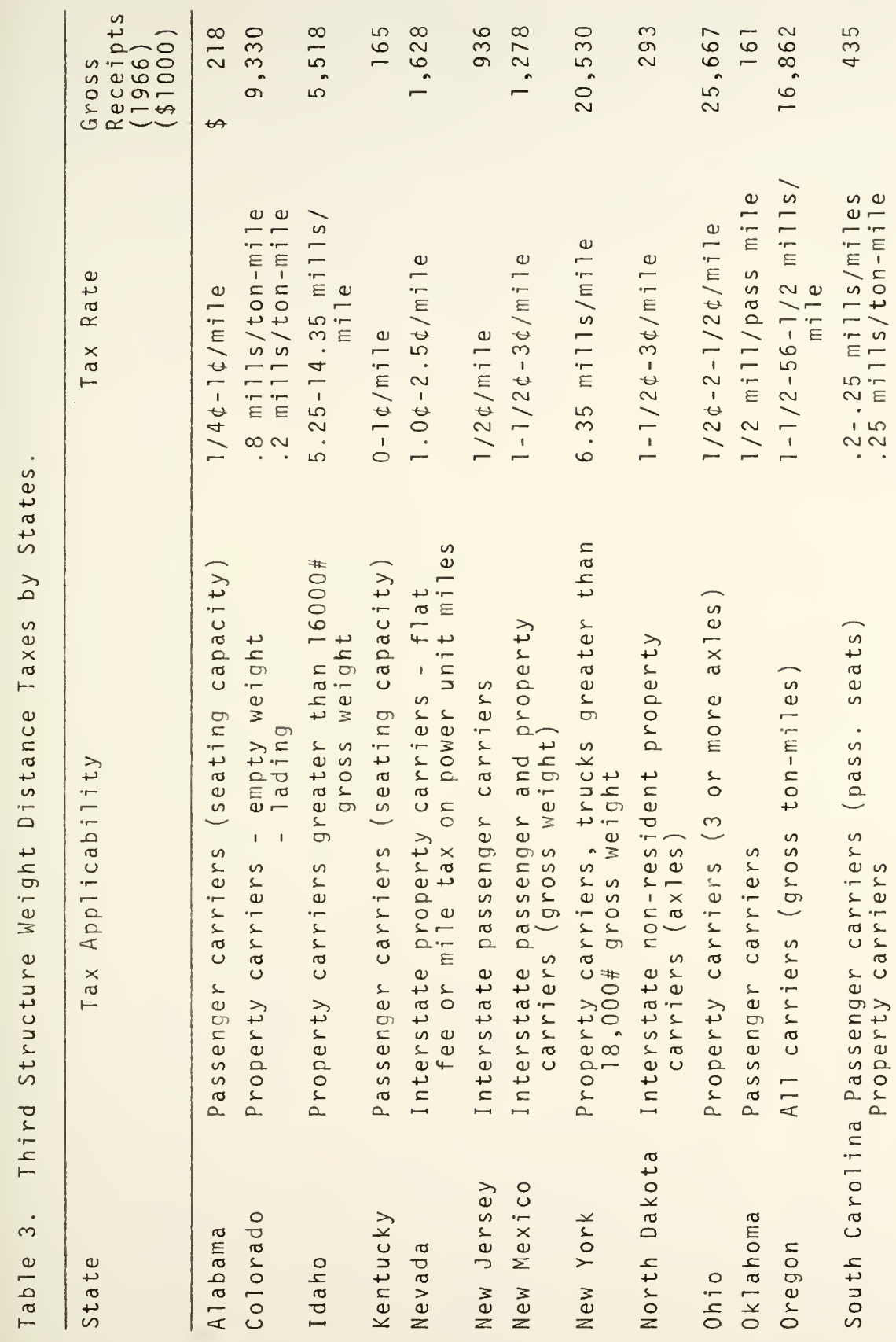




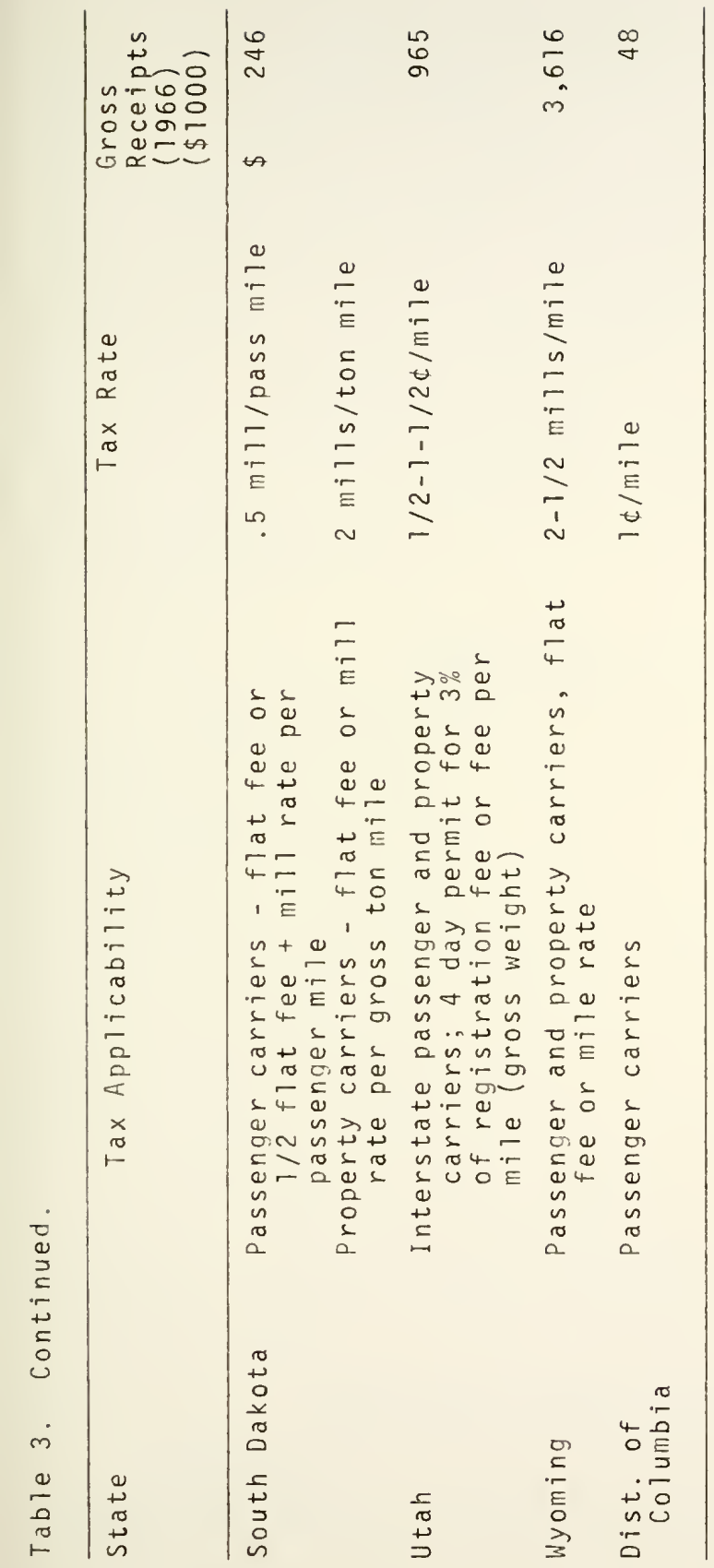


If Indiana were to impose some form of mileage tax what revenue would likely be incurred over the next twenty years? To answer this question a basic framework for the levy of such a tax must be established. For simplicity, the axle format was used. Conversion of estimates for some, other formula such as ton-mileage would entail only minor additional calculations. Resulting calculations indicated the average annual revenue which could be expected from imposing an axle mile tax similar to the ohio axle mile tax would be $\$ 36,309,000$.

\section{Gross Receipts Taxes}

An alternative form of highway use tax which has been adopted by some states is the gross receipts tax. Though many states impose taxes on the gross receipts of motor carriers in connection with general taxes, at least five states - Arizona, California, Montana, Virginia, and Washington - - imposed this tax as of 1966 as a special levy on motor carriers. The revenues from this tax accrue to the various highway funds as an added highway revenue source.

This form of tax seems to bear no relation to the principle of equity in taxing motor vehicles, thus no revenue estimates will be made for Indiana.

\section{Interstate Vehicle Taxation}

A problem which has developed as a result of the tremendous increase in interstate trucking is that of assessing 
Table 4. Third Structure Gross Receipts Taxes by States.

State

Rate

Receipts 1966

$(\$ 1000)$

Arizona

$2-1 / 4 \%$ of Gross Receipts

$\$ 4,192$

California

$1-1 / 2 \%$ of Gross Receipts

21,726

Montana

$1 / 2 \%$ of Gross Receipts

356

Virginia

$2 / 10 \%$ of Gross Receipts

510

Washington

$1 / 2-1-1 / 2 \%$ of Gross Receipts

55

Source: [14]

commercial vehicles which are non-residents of a state, yet frequently travel its highways. To Indiana, described as "the crossroads of America," this is a particularly impor$\operatorname{tant}$ issue.

Private passenger vehicles because of their small fuel capacity usually must buy gasoline in each state in which they travel, thus they pay in the form of the gasoline tax at least a portion of their share of highway taxes. This factor has been accepted by all states as evidenced by the freedom of travel for private passenger vehicles throughout the United States. Larger motor carriers however, with their much greater fuel capacity, can if so desired travel completely through a state without purchasing fuel or paying any form of tax in that state. The attempt to assess these vehicles with some measure of their share of highway costs 
has fostered considerable administrative discomfort, and has led to the formulation of reciprocity agreements.

For out of state vehicles not under reciprocity agreements, most states require payment of some in-state tax. Some forms of taxing these vehicles are partial or full registration fees, mileage taxes, short-term travel permits, payment of the tax on fuel used in the state whether purchased there or not, and several forms of surtax. Kentucky for example, levies a 2 cent surtax per gallon of motor fuel consumed within the state by out of state and in state carriers with three or more axles. It is estimated that this surtax returns in excess of 1.6 million dollars annually [29].

Because of the variability of interstate travel and the difficulty of assessing the amount of such travel in Indiana no revenue forecast will be attempted for this study. Such a tax, because of its relatively high cost of collection and the fact that many interstate trucks already purchase fuel in the state, would net Indiana only a small amount of revenue. The tax which appears most popular for interstate travel is the required payment of state fuel tax on fuel used in the state whether purchased there or not. Twentythree states presently use this form of tax for assessing interstate trucking. 


\section{Local User Taxes}

It is indicated by the Needs Study that county roads have the largest gap between revenues and needs of all highway classifications. It has been estimated that at present tax rates and sources, the counties will have an average annual deficit of $\$ 101$ million. As suggested in a later section, a greater usage of existing revenue sources such as the Cumulative Bridge Fund would help to reduce this deficit. The levying of highway user imposts at the local level is being used in some states. Six states in 1966 imposed some form of local user impost. Local taxation could in theory assume forms similar to almost all levies assessed at the state level; however in practice the limited size of the counties and the high fixed administrative requirements, rule out most forms of taxation, such as the fuel tax, mileage tax, etc. The registration fee, or some similar form of annual assessment, levied on motor vehicles does, however, lend itself more readily to local application. Such a fee could not as easily be avoided as could a fuel tax or mileage fee, and administrative costs would be low since registration fees are already collected at the local level.

An application of such a tax has been put into affect in Marion County, known as a "Wheel Tax." The Metropolitan Thoroughfare Authority Act of 1963 authorized counties containing a city of the lst class to levy an annual tax, sometimes referred to as the wheel tax, on county oriented 
vehicles, to provide funds for the construction, broadening and improvement of thoroughfares within the county and the city. The schedule of tax levies was as follows:

vehicles up to 7,000 lbs. declared gross weight $\$ 10$ trucks greater than 7,000 1bs. declared gross weight 20 trailers

tractor and semi-trailer

buses

No tax was to be greater than $\$ 12.50$ on either a tractor or trailer separately

Vehicles in a 17 classes above 7,000 7bs. declared gross weight, which operated less than 20 percent within the county were exempt from this tax.

Subsequent to the enactment of this act all passenger vehicles were excluded from assessment on the basis of a ruling that passenger vehicles were not a specified motor vehicle classification as described in the Acts of 1945 , the authority for the class divisions of this act.

Though the present legislation restricts the levy of a wheel tax to those counties containing a city of the lst class an expansion to include all counties would provide an added revenue source at the county level. If a uniform county registration fee of $\$ 10$ were 1 evied against a 71 passenger cars registered in the State of Indiana the average annual return over the next twenty years would amount to $\$ 26,170,000$ for the support of county roads. If the annual county fee for each truck were $\$ 20$, or twice that of 
passenger cars, the annual average revenue, 1966-1985 is estimated to be $\$ 11,640,000$.

\section{Excise Taxes}

An excise tax is an internal tax levied on the manufacture, sale, or consumption of a commodity by a governmental jurisdiction. Economic theory dictates that excise taxes should be placed only on those commodities for which supply and demand are inelastic [30]. Thus we have experienced the development of federal excise taxes on motor fuel, automobiles, auto parts, and accessories.

Table 5 indicates those items upon which a federal excise tax is currently placed, the unit rates levied, and the excise taxes paid by Indiana to the federal government in 1966. Currently the federal government dedicates all of the fuel tax, and a part of the remaining taxes to the Federal Aid Highway Trust Fund; the remainder is deposited in the General Treasury.

It might be useful to consider such a tax levied at the state level on all motor vehicle sales. If a 1 percent state excise tax were to be placed on the sale of automobiles and trucks the estimated average annual revenue 1966-1985 would be $\$ 8,696,000$ for cars and $\$ 4,665,000$ for trucks.

A recent study by J. R. Wentworth \& Associates, on behalf of the Automobile Dealers Association of Indiana, Inc., has suggested a state excise tax system on the sale of automobiles to replace the present property tax. This study 


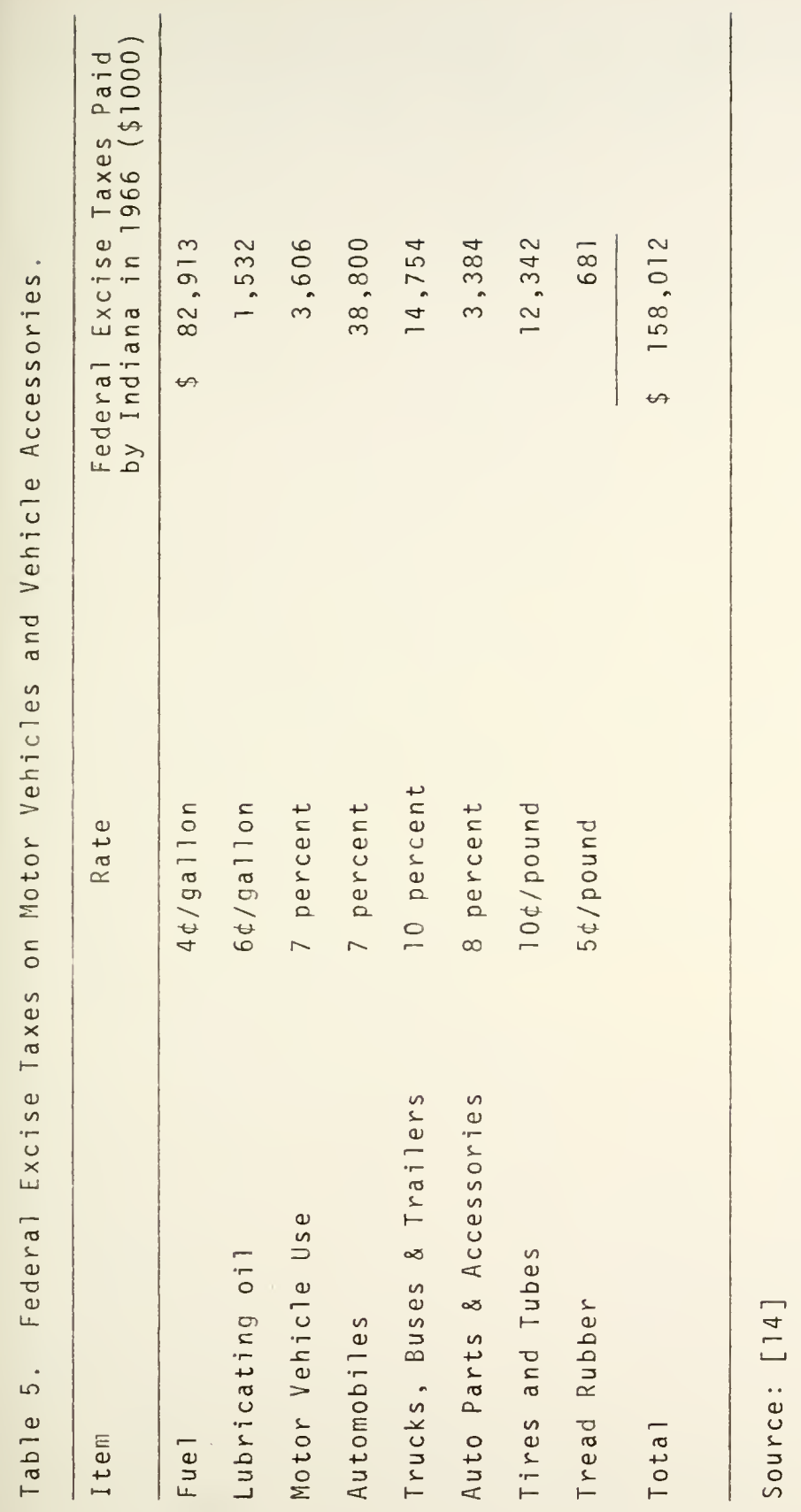


estimated that such a system could increase the county tax yield by as much as $\$ 17,000,000$ annual1y.

\section{Access Fees}

To establish a framework for financing highway improvements every effort should be made to determine those who benefit directly or indirectly from highways and to what extent this benefit is realized. One group given little consideration in the past is composed of those who have access to a highway either for the conduct of their business or to their residence. Richard A. Tybout has stated: "The condition of a highway can mean economic life or death to a roadside establishment" [31]. In the past little or no effort has been made to assess those having access to highways. While some states do require the payment of a fee for acquiring an access permit it is usually minimal. Indiana requires a permit to obtain access to a state highway but at no cost to the applicant.

Assessment of these benefitors could take several forms. At the time of application a high fee might be specified according to the type of access, private or commercial, the number of access points, and the required access standard. Alternately an annual levy might be applied to each access point. The funds from this levy could be then directed to the Motor Vehicle Highway Account.

Even though an access tax levy might not form a major revenue source, it might achieve two desirable objectives: 
First, it would directly assess a benefit received by the person or business having access, and second it would discourage requests for access points where not needed, thus improving the operation of the highway.

Over the past five years access permit applications have been made to the Indiana State Highway Commission at a rate of approximately 2000 annually, half of these being commercial access requests.

A 1956 estimate of access points on rural state primary and secondary highways in Indiana suggests that there is an average of 15.8 and 12.8 driveways per mile respectively. Assuming an average of 15 per mile for all highways, for the 91,000 miles of highways in Indiana give a total of 1,365,000 access points [32]. This estimate is likely conservative since the above study included only rural highways. At a 1.00 dollar annual fee per access the revenue would be $\$ 1,400,000$ annually increasing gradually as time passes. If higher rates were established the income would be even greater and the added incentive to eliminate unnecessary access points would be of considerable advantage in reducing highway congestion and accidents.

\section{Assessment of Utilities Using Highway Right of Way}

As a consequence of their extensive use of highway and street right-of-way, utility comparies have nearly eliminated the high costs of obtaining separate rights-of-ways for their lines. In addition the easy access to their facilities 
provided by the parallel street or highway, considerably reduces the costs of maintenance and repair. In light of these major cost savings it seems impossible to question the benefit which utility companies - such as power, telephone, water and gas -- receive from the existence of highways. The Final Report of the Federal Highway Cost Allocation Study states; "Studies made in a number of states establish the fact that the privilege of occupying the highway rightof-way is of substantial value to both publicly owned and privately owned utility enterprises." [7]

A study conducted in Utah in 1960 has estimated that the cost of easements on private land for utilities now occupying public right-of-ways, values at an annual charge per customer would amount to, for power $\$ 3.36$ and for telephone $\$ 2.03$ [33]. These valuations do not include an assessment of the value of easy access to lines afforded by the highway right-of-way.

Though the benefits accruing to utilities through their use of public roads and streets is unquestionable, a study conducted in Georgia has concluded that it is likely that under efficient management and effective regulation these benefits are passed on to the consumer in the form of Tower utility rates [34]. A utility user charge would shift some of the burden of highways not to the utility companies but directly to the utility users. 
An argument against assessing utilities for use of highway rights-of-way is the legal question of their right to be there. Legal agreements dating back to the early days of utilities have given them considerable rights as to their location. These rights to be on the right-of-way might in the final analysis be as substantial as the rights of the highway itself.

Though the question of justifying a tax levy on utilities is a difficult one, such a levy could form a lucrative tax base. It has been estimated that the percentages of highway and street right-of-way used by utilities in Indiana are as follows:

$\begin{array}{ccccc} & \text { Power } & \text { Telephone } & \text { Gas } & \text { Water } \\ \text { Rura1 } & 90 \% & 90 \% & 2-3 \% & 2-3 \% \\ \text { Urban } & 50 \% & 50 \% & 60 \% & 70 \%\end{array}$

Though these percentages are estimates, one need only look at the profusion of lines both above and below ground to assess their validity. Considering that there are over 91,000 miles of highways, roads and streets in Indiana, 12,903 of these miles in urban areas, suggests that there are approximately 77,000 miles of power 1 ines, 77,000 miles of telephone lines, 10,000 miles of gas lines and 11,000 miles of watermains.

The Indiana State Highway Commission now requires a permit for erection of new lines as well as a unit fee on 
certain types of line placement. These fees however are based on an estimate of the cost incurred by the state for inspection and maintenance of the right-of-way where disturbed by the line placement.

An annual 1.00 dollar levy per mile of utility, using a highway right-of-way, either directly assessed to the utility company or in the form of a tax paid by the utility user, would amount to approximately $\$ 175,000$ annually over the next twenty years. A $\$ 10.00$ levy per mile would amount to $\$ 1,750,000$ annually. According to the Georgia Study, the benefit of utilities using highway right-of-way amounted to $\$ 2.85$ per person; applying this rate to Indiana the average annual benefit is $\$ 15,650,000$.

\section{Roadside Outdoor Advertising Fees}

Through the years as Indiana's highway mileage has been increasing to its present total of over 91,000 miles, the outdoor advertising industry has used the highways for its benefit. Every driver on today's roads is well aware of the success of this industry as evidenced by the abundance of roadside signs in both rural and urban areas. There is little doubt of the benefits derived by outdoor advertisers from the existence of highways; in fact the entire business owes its exixtence to highways and highway traffic.

The success of any form of advertising is dependent on the number of pairs of eyes to which it is exposed; thus without highways and the traffic they carry the success of 
outdoor advertising would be non-existent. It has been stated that outdoor advertising at a cost of approximately 25 cents per one thousand exposures, probably leads the advertising field for economy [35].

President Kennedy when commenting on the national policy to control roadside advertising on the Interstate highway system (Federal Aid Highway Act - 1958) states, "The (Interstate Highway) system was not intended to provide a large and unreimbursed measure of benefits to the billboard industry." It would seem that there is ample justification for applying this statement to all highway classifications.

The question of what restrictions can be placed on billboard locations, though important, is not the concern of this report. The concern is, if we do allow roadside advertising to use the highways, is there justification in assessing them a portion of highway costs as some function of the benefits received. Though there is considerable evidence of such justification, determination of a measure of value received by the advertiser would be quite difficult to define. The Final Report of the Highway Cost Allocation Study presented to the 87 th Congress concluded:

Because no systematic means of evaluating the benefits of the Federal Aid highway program to this industry (roadside advertising) is available, no finding is made as to the magnitude of a possible non-user component of cost responsibility to be derived from outdoor advertising. It is a fact, nonetheless, that the outdoor advertising business derives its 1 iving, so to speak, from the highways and does so strictly as a "non-user. "Because the magnitude of the business itself is not very great, 
it cannot be looked to as a large producer of highway revenues in any event; but that outdoor advertising companies and their customers benefit from highway improvements is unquestionable ([7], p. 109).

In 1958 there were seventeen states including the District of Columbia which required permits ranging from an annual fee of $\$ 5.00$ to $\$ 200$ for engaging in the business of outdoor advertising. Eighteen states require a permit for the erection of outdoor advertising devices. This permit is often based on an annual rate of approximately 1 cent per square foot of area [36].

Table 6 is a summary of roadside advertising signs on Indiana Federal Aid Primary and Interstate Highways. Though this represents only about 12 percent of the mileage in Indiana, these highways carry approximately 60 percent of the travel. Because of the dependence of roadside advertising on exposure to traffic, the roadside signs which this table represents is likely a high percentage of the total in the state. It may also be assumed that with increasing concern for the regulation on location and spacing of signs, that the number of signs will not significantly increase in the future. Thus revenue estimates for 1966-1985 based on the present sign inventory could be representative. The rate schedule in Table 7 based on 10 cents per square foot is not presented as a recommendation; rather it suggests how a tax on roadside advertising might be levied. 
Table 6. Outdoor Advertising Signs on Interstate and Federal Aid Primary Highways in Indiana (1966).

\begin{tabular}{lrrr} 
Size & \multicolumn{2}{c}{ Location } & Total \\
\cline { 2 - 3 } Lest.) & \multicolumn{1}{c}{ Rural } & Urban & \\
\hline $50-100$ & 21,107 & 6,581 & 27,688 \\
$100-200$ & 2,470 & 623 & 3,093 \\
$200-500$ & 2,172 & 1,075 & 3,247 \\
Greater than 500 & 2,694 & 1,478 & 4,172 \\
*Unclassified & $\frac{416}{29,553}$ & $\frac{110,370}{500}$ & $\frac{1,194}{39,923}$ \\
Total & $\frac{694}{10}$ &
\end{tabular}

Source: [37]

Table 7. Possible Outdoor Advertising Permit Fee Schedule.

\begin{tabular}{|c|c|c|c|}
\hline Size & & & nit \\
\hline (Sq.Ft.) & Number & $\begin{array}{l}\text { Fee } \\
(\$)\end{array}$ & $\begin{array}{c}\text { Revenue } \\
\text { (\$) }\end{array}$ \\
\hline 50 & 27,688 & 10.00 & 276,880 \\
\hline $50-100$ & 3,093 & 10.00 & 30,930 \\
\hline $100-200$ & 3,247 & 15.00 & 48,700 \\
\hline $200-500$ & 4,172 & 35.00 & 146,020 \\
\hline 500 & 529 & 50.00 & 26,450 \\
\hline Unclassified & 1,194 & 15.00 & 17,910 \\
\hline Total & 39,923 & & 546,890 \\
\hline
\end{tabular}




\section{Cumulative Bridge Funds}

The Cumulative Bridge Funds authorized in 1951 (Acts 1951 ch 299 ss 1, p. 989 amended in 1957 Acts Ch 76 ss 1 , p. 135) have become an important revenue source for the maintenance, repair and construction of bridges and grade separations in Indiana's counties, cities and towns. The Indiana statutes authorize local officials to establish a tax levy on all taxable personal and real property for the maintenance, repair and construction of all county, city, and town bridges.

A county wishing to levy such a tax must first hold a public hearing for the affected taxpayers and then obtain approval from the State Tax Commissioners. Once approved the tax may be levied annually for a period of five years at a rate not greater than 20 cents per $\$ 100$ of taxable property.

This revenue source is optional with the individual counties. In 1966 approximately 90 percant of the 92 counties had established cumulative bridge funds. However, only eleven of these counties levied the full 20 cents as authorized. As a result considerable authorized local revenues from the public were not collected. In 1966 the total income to all counties having cumulative bridge funds was approximately $\$ 7.3 \mathrm{million}$. If the maximum levy of 20 cents per $\$ 100$ had been applied in all 92 counties, the total income from cumulative bridge funds would have been approximately $\$ 18.6$ million; i.e., $\$ 11.3$ million more than was 


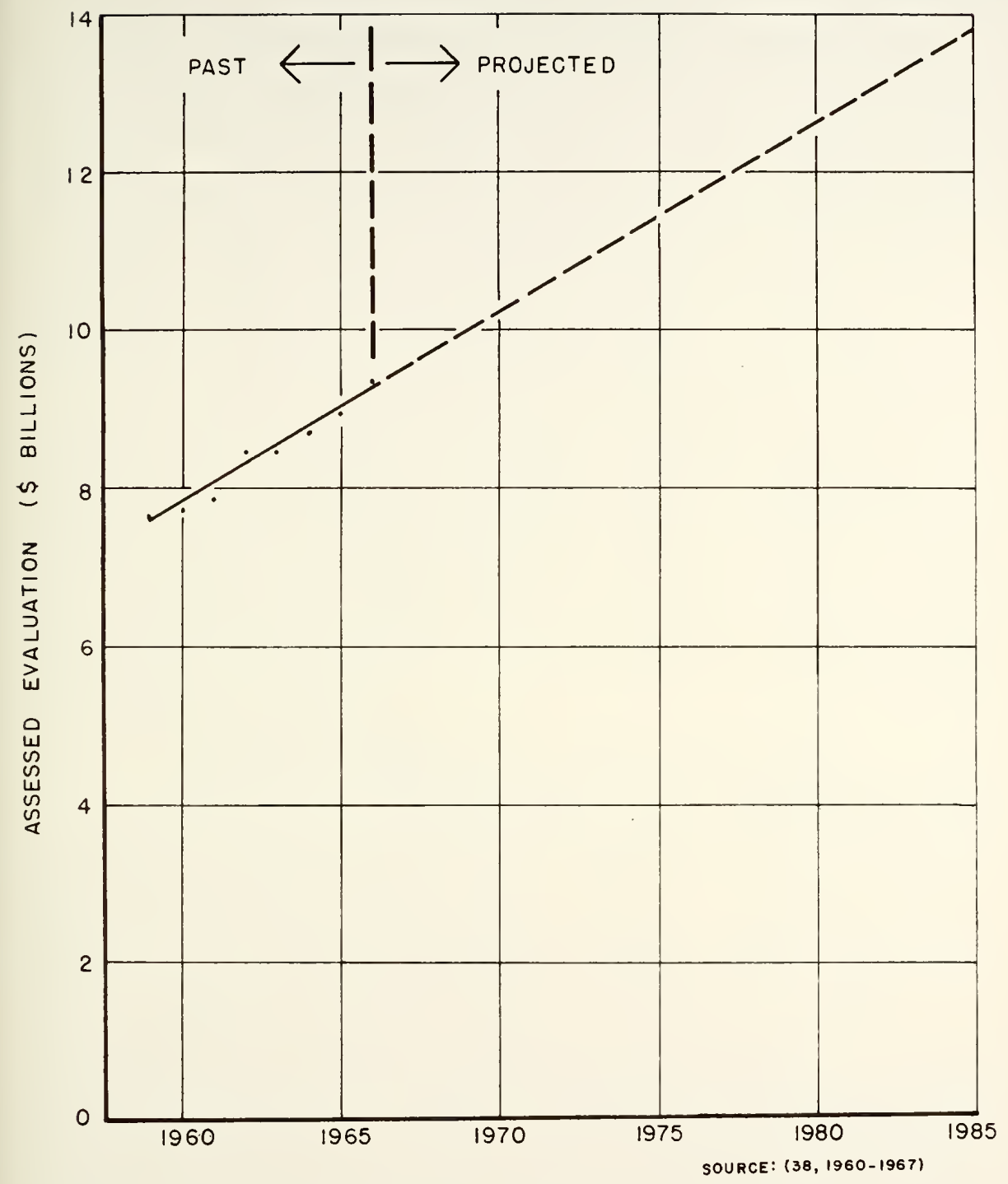

FIGURE 15. INDIANA COUNTY ASSESSED PROPERTY

EVALUATION, 1959-1985. 
collected. If present property values continue to increase at recent rates the average annual revenue from a 20 cent levy for the period 1966-1985 for all counties is estimated to be $\$ 23.3$ million. For each 10 cent levy in addition to the presently authorized 20 cents per $\$ 100$ the average annual revenue if fully assessed would be approximately $\$ 11.65$ million. These additional revenues could be directed at the local level for use in both rural and urban areas.

It has been suggested by some that cumulative bridge funds might be expanded to include road construction as we11. Such action would expand the usage of these funds and would not remove them from their basic purpose of building and maintaining transportation facilities, whether they be bridges or highways.

\section{Personal Property Tax on Motor Vehicles}

A discussion of Indiana's road user taxes would be incomplete and misleading without reference to the personal property tax levied on all motor vehicles. Indiana is among twenty-one states (1966), including neighboring I11inois and Kentucky, which impose property taxes on motor vehicles. Nine states levy an excise tax on motor vehicles and twenty-one have no similar tax although six of these impose a very high registration fee in lieu of other general taxes.

Revenues from the property tax are collected at the county level annually with tax levies varying from county 
to county. No part of these receipts are used for highway purposes in Indiana. All revenues are deposited in the general fund. Economists argue that property taxes on motor vehicles should be directed to the general fund and not to highways on the basis that property taxation is a tax for the collective good and motor vehicles have no right to an exemption from it. If Indiana's personal property tax were widely based, such an argument would bear considerable weight, however as a result of the difficulty in assessing most personal property, the property tax is now levied against individuals onty on their motor vehicles, ajrplanes, and outboard motors, with the levy on motor vehicles making up the major portion of revenues.

Thus the initial general tax base has developed into, for the most part, a highway oriented tax and a case can be made for directing these revenues to highway purposes. However, in considering such a move, it must be remembered that if general funds are thus reduced the revenues transferred must be obtained from some other source or an increase of an existing source. The highway dedication of personal property tax funds is therefore a policy rather than an economic decision to be made in light of the entire tax structure. Estimates of potential revenues from the personal property tax over the next twenty years are made on the basis of certain primary assumptions:

1. The average age of automobiles and trucks will continue to be between 5.5 and 6.0 years and 7.5 to 
8.0 years respectively.

2. The value of motor vehicles of similar quality and age will be similar to today's values.

Based on the weighted average county tax levy for 1967 of $\$ 7.60$ and the 1966 vehicle registrations, the revenues from the personal property tax on motor vehicles in 1966 should have amounted to approximately $\$ 48,100,000 \quad(\$ 23.20$ per vehicle) for automobiles and $\$ 14,300,000$ (\$30.30 per vehicle) for trucks. Based on the estimated increases in registrations and the above assumptions the 1985 revenues are estimated at $\$ 73,500,000$ for automobiles and $\$ 21,400,000$ for trucks. This provides an estimated average annual revenue for the twenty year period of $\$ 78,650,000$ for al1 motor vehicles.

In addition to the arguments for changes in the personal property tax, some have suggested its elimination. A 1965 report "An Excise Tax on Automobiles for Indiana" suggests that the present property tax is inequitable in that a large number of vehicles escape taxation. The report estimates that; 1) approximately $1 / 2$ million vehicles are currently escaping assessment, and 2) hundreds of thousands of dollars are lost on uncollected assessments through no fault of county officials, but rather because of the long delay between assessment and collection as well as the mobility of the population.

The personal property tax, because of its dependence on vehicle value, appears to run counter to the benefit 
principle of highway taxation. Several studies have suggested that the property tax on motor vehicles must be included to assess the total highway user taxes paid. If this general tax is to be included as a user tax, what is then to prevent including other taxes assessed against highway related items, such as sales tax, excise tax, etc.

Inclusion of the property tax presents additional problems. The tax paid by a new vehicle versus an older one differs considerably so that any statement of the effect of the property tax must be made on the basis of some age class. Some studies which have discussed this tax have considered each vehicle to have a value nearly that of a new vehicle and thus have tended to over estimate the property tax on vehicles. An average varue based on average age suggests the amount of property tax paid on the average vehicle is not a large amount. The purpose of the above is to point out that some reports have suggested that Indiana stands high in the national rating of taxes paid by motor vehicles when one includes the property tax. Some of these have reported an assumed property tax on vehicles which appears to be more than double that which is actually assessed against the average vehicle.

\section{State Sales Tax}

The Indiana Sales and Use Tax enacted in 1963 imposed a 2 percent sales tax on retail sales, and a 2 percent use tax on the use, storage or other consumption of tangible 
personal property purchased at retail, but not subject to sales tax. The revenues collected from the sales tax in 1966 amounted to $\$ 172.7$ million.

It has been conservatively estimated that Indiana's real per capita personal income will increase 2.3 percent annually over the next twenty years [39]. This coupled with the anticipated 30 percent population increase over the same period gives an estimated 110 percent increase in Indiana's total personal income from $\$ 10.8$ to $\$ 22.8$ billion. Since spending is proportional to income (although there is a tendency for the percent of income spent to decrease with rising income) it seems reasonable to assume that revenues from the sales tax will increase in a similar proportion. On this assumption the estimated average annual revenue between 1966 and 1985 is $\$ 259$ million from a 2 cent sales tax.

Sales Tax on Motor Fuel

A sizable portion of the Indiana sales tax is derived from highway users in the form of sales taxes on motor fuel, motor vehicles, and auto parts. (Sales tax collections for 1966 from automobile dealers and service stations amounted to $\$ 28,474,000$ or 16.5 percent of total sales tax collected) [40]. Many states have exempted motor fuel from sales taxes. There seems to be no justification for this measure since a sales tax should be as widely based as possible.

It is estimated that the sales tax on motor fuel alone based on estimates of fuel consumption increases should 
produce an average annual revenue of nearly $\$ 9.0$ million during the next twenty years.

\section{Sales Tax on Motor Vehicles and Parts}

Forty states including Indiana presently impose a sales tax affecting motor vehicles ranging from 1.5 to 5 percent. In Fiscal year 1966-1967 Indiana's 2 percent sales tax on automobiles and auto parts amounted to approximately $\$ 14.9$ million and $\$ 1.0$ million respectively. If present auto sales trends in Indiana continue these collection rates should remain about the same over the next twenty years.

\section{State Income Tax}

over thirty states impose taxes on individual income and on corporate income. These taxes are relatively low and only slightly progressive in comparison to federal income taxes. They usually range from 1 to 3 percent for 10 w incomes to 6 percent for high incomes and rarely as high as 10 percent [41]. Indiana presentiy imposes a 2 percent tax on income.

Assuming that revenues from personal and corporate income taxes will increase in proportion to the estimated increase in total state income the projected average annual revenue 1966-1985 is in the order of $\$ 432 \mathrm{mil1ion}$ for Indiana's 2 percent income tax. 


\section{Alcoholic Beverage Tax}

It has been suggested that since a large percentage of accidents can be attributed to the influence of alcohol (it has been estimated that approximately 60 percent of automobile accident fatalities had a blood alcohol concentration greater than 0.05 percent) [42], a tax on alcohol might justifiably be expended for highway purposes. Though the logic of this argument may bear some fallacies, the alcoholic beverage with its relatively inelastic demand forms an excellent tax base. In 1966 revenues from the Indiana alcoholic beverage tax amounted to $\$ 21.2$ million. If the 1963-1967 trend in revenues collected continues, the estimated average annual revenue from this tax at current levels for 1966-1985 amounts to $\$ 28.6$ milition.

\section{Cigarette Tax}

Cigarettes also, because of the inelastic demand for them, have become a well used tax base. In 1966 the revenue from the cigarette tax amounted to $\$ 36.6$ million. Trends suggest, possibly because of a decline in cigarette sales, that revenues from this tax are not increasing. If this continues the estimated average annual revenue for the next twenty years from the cigarette tax at the current level may be taken as the present $\$ 36.6$ million annually.

\section{Tax on Motor Vehicle Related Insurance}

The Tax paid on motor vehicle insurance premiums has been cited by some as a highway related tax and thus a 
justifiable revenue source for highway dedication. A use tax of 2 percent is currently assessed against insurance premiums in Indiana. For 1966 total fire and casualty taxes in the state amounted to almost $\$ 8$ million. On a national level, approximately 62 percent of the fire and casualty insurance is motor vehicle related insurance. Applying this information results in a 1966 income from this tax for motor vehicle insurance of about $\$ 5$ million.

The growth of insurance rates in the motor vehicle field has been tremendous in recent years. Estimating this growth to continue over the next 20 years results in an estimated average annual revenue, 1966-1985, from the current 2 percent insurance tax on motor vehicle insurance, of $\$ 11,500,000$.

\section{Summary - Sources of Revenue}

A summary of the anticipated revenue from the various sources of revenue included in this study is given in Table 8. Those which would be clearly classified as public taxes are:

Access Fee

Utility R/W Use Fee

Billboard Tax

Cumulative Bridge Fund

Sales $\operatorname{Tax}(\operatorname{Total})$

State Income Tax

Alcoholic Beverage Tax

Cigarette Tax 


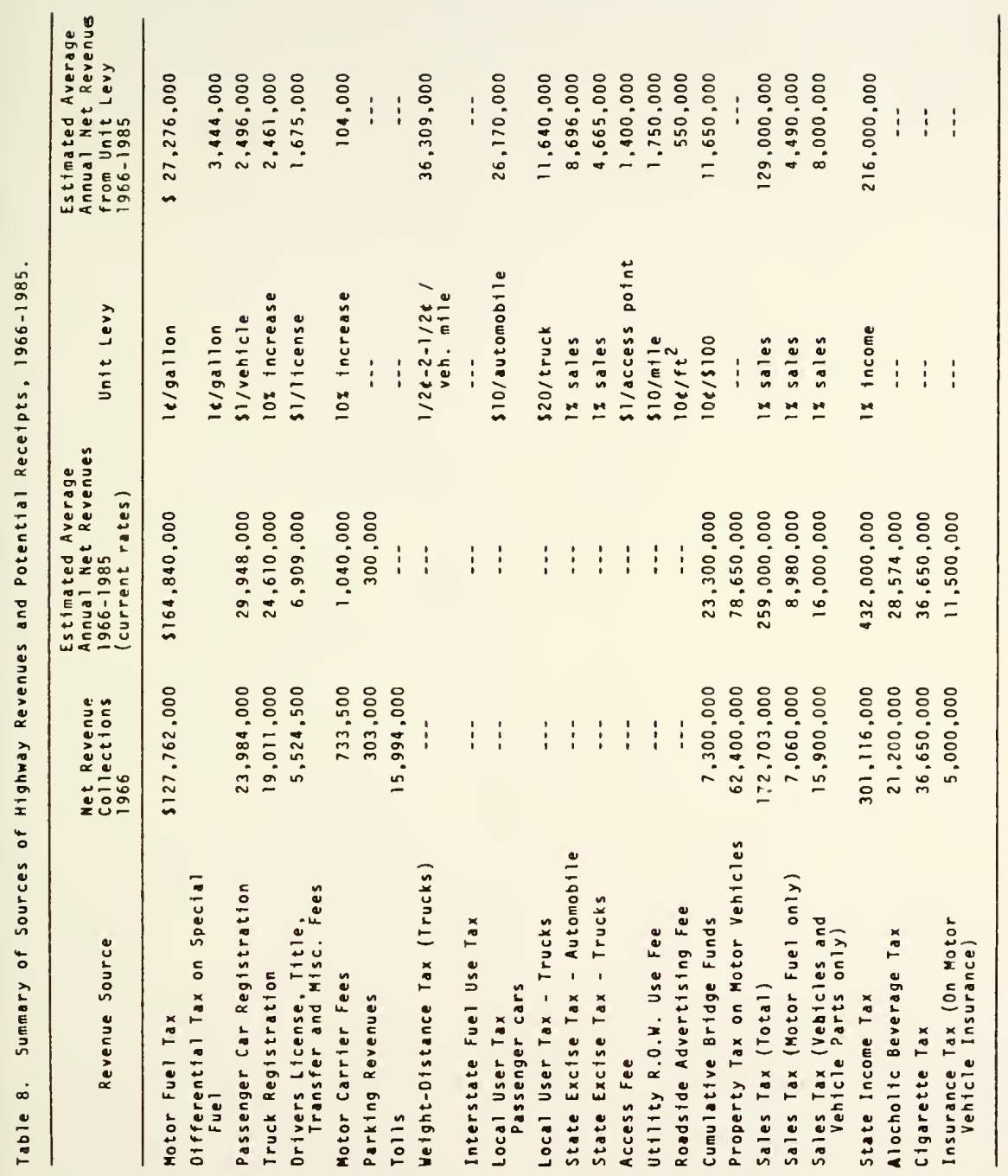


Those which are clearly highway user fees are:

Motor Fuel Tax

Differential Tax on Special Fuels

Registration Fees

Drivers Licenses

Motor Carrier Fees

Parking Revenues

To11s

Mileage Tax

Interstate Fuel Use Tax

Local User Taxes

some would insist that the following are also highway user taxes while others would classify them as public taxes:

State Excise Taxes

Property Tax on Motor Vehicles

Sales Taxes on Vehicles, Parts and Fuel

Insurance Tax (on Motor Vehicle Insurance)

Some of the above taxes could be collected either at the local level or at the state level as legislation would permit. For example a vehicle registration fee could be collected and retained by the county or collected by the state and returned to the county. The same is true of several of the other taxes. A local sales tax could also be authorized. The property tax on motor vehicles could be authorized for use as highway funds. Moreover, many combinations of taxes could be used to obtain the required additiona) $\$ 187$ million average annual revenue. 
How they are obtained will determine the allocation of cost responsibility the Legislature decides is best for Indiana. Where they are collected - at the state or local level - - should determine the proper distribution formula of state collected funds. 
CHAPTER V. DISTRIBUTION OF HIGHWAY USER REVENUES

An important part of any highway finance policy is the distribution of funds collected at the state level among various levels of government, as well as the distribution at each of these levels.

The decision as to what percentage of user revenues should be distributed to each government level -- state, county, or city -- is basically one of legislative policy. However such a decision should be tempered by the needs of each level, the differences in construction, maintenance, and operation costs occasioned and the availability of local sources of financing.

The distribution of funds at each government level and the distribution among government levels may be quantified by measurement of the relative use of or the demands placed on the appropriate facilities, in other words, the relative need for the facilities. The practical difficulty lies in the measurement of these needs. Indiana, however, during the period 1965-1966 at the direction of its Legislature had performed a Needs Study to establish the needs of state, county and city roads and streets. This information was therefore available for a quantification of the relative needs between and at governmental levels. 
The use of needs information as the basic variable in distribution formulas, however, has not resulted. The major reason for this fact is that highway needs are dynamic and constantly changing whereas needs studies are, because of their high cost infrequently performed. Distribution according to needs, therefore, is often accomplished by determining other factors which are easily and reliably measured and correlate well with needs.

\section{Distribution Formula Criteria}

Of the many symptomatic criteria available, population and motor vehicle registration are probably the most reliable yardsticks of highway needs. Other factors being widely used are mileage, area, assessed evaluation and fuel consumption. Table 9 lists the factors used in the distribution of user funds for highways by other states.

\section{Distribution Factors}

Population. Population has proved to be a reliable and equitable measure of highway need especially for urban areas. It is only logical that with increased population comes increased demand for transportation. The major drawback of this criteria is that a state wide census is taken only every ten years. An area growing more rapidly than the overall region would thus be penalized in that growth between census would not be reflected. Unfortunately rapidly growing areas usualiy have the greatest need. The possibility 
Table 9. Distribution Criteria as Used by 0 ther States.

\begin{tabular}{|c|c|c|c|c|c|c|c|c|c|c|c|}
\hline & MILEAGE & $\begin{array}{l}\text { ASSESSED } \\
\text { EVALATION }\end{array}$ & POPULATION & AREA & EQUALLY & \begin{tabular}{|c|} 
VEFHCLE \\
REGISTRATION
\end{tabular} & \begin{tabular}{|c|} 
FUEL \\
CONSUMPTION \\
\end{tabular} & $\begin{array}{l}\text { FUEL } \\
\text { SALES }\end{array}$ & NEEOS & TRAVEL & THERS \\
\hline ALABAMA & & & $x$ & & $x$ & $x$ & & & & & \\
\hline ALASKA & & & & & & 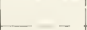 & & & & & \\
\hline ARIZONA & & & $x$ & & & & $x$ & & & & \\
\hline ARKANSAS & & & $x$ & $x$ & $x$ & $x$ & & & & & \\
\hline CALIFORNIA & $x$ & & $x$ & & & $x$ & & & & & \\
\hline COLORAOO & $x$ & & & & & $x$ & & & & & \\
\hline CONNECTICUT & $x$ & & & & & & & & & & \\
\hline DELEWARE & $x$ & & $x$ & & & & & & & & \\
\hline FLORIOA & & & $x$ & $x$ & & & t & & & & $x$ \\
\hline GEORGIA & $x$ & & & & & & & & & & \\
\hline HAWAll & & & & & & & & & & & \\
\hline IOAMO & $x$ & & $x$ & & $x$ & $x$ & & & & & \\
\hline ILLINOIS & $x$ & & $x$ & & & $x$ & 1 & & & & \\
\hline INOIANA & $x$ & & $x$ & & $x$ & $x$ & . & & & & \\
\hline IOWA & & & $x$ & $x$ & $x$ & - & 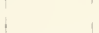 & & & & \\
\hline KANSAS & & $x$ & $x$ & $x$ & $x$ & . & . & & & $x$ & $x$ \\
\hline KENTUCKY & & & $x$ & $x$ & $x$ & & + & & & & \\
\hline LOUISIANA & & & & & & 4 & $-x$ & $x$ & & & \\
\hline MAINE & $x$ & $x$ & 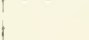 & & & + & 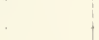 & & & & \\
\hline MARYLAND & $x$ & 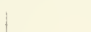 & 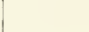 & & & t. & , & & & & \\
\hline MASSACHUSETTS & $x$ & & & & & & , & & & & \\
\hline MICHIGAN & $x$ & . & $x$ & & $x$ & $x$ & , & & & & \\
\hline MINNESOTA & $x$ & i & $x$ & & x & $x$ & . & & $x$ & & \\
\hline MISSISSIPPI & & . & $x$ & $x$ & & $x$ & . & & & & X \\
\hline MISSOURI & & . & $x$ & $x$ & & i & + & & & & $x$ \\
\hline MONTANA & & & 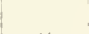 & & & $x$ & & & & & 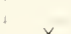 \\
\hline NEBRASKA & & . & $x$ & & & $x$ & & & - & & $x$ \\
\hline NEVAOA & $x$ & 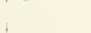 & $x$ & $x$ & & . & $x$ & & & $x$ & ! \\
\hline NEW HAMSHIRE & $x$ & $x$ & . & & & . & . & & - - & & 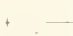 \\
\hline NEW JERSEY - & $x$ & 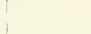 & $x$ & $x$ & $x$ & & . & & & & , \\
\hline NEW MEXICO & $x$ & $x$ & 1 & & & $x$ & . & & & $\vdash$ & . \\
\hline NEW YORK & $x$ & & + & & & $x$ & & & & , & 1 \\
\hline N CAROLINA & $x$ & + & $x$ & & & $x$ & & & & ' & , \\
\hline N OAKOTA & & i & , & & & $x$ & + & & & t & . \\
\hline ОнІо & $x$ & . & 1 & & $x$ & $x$ & +- & & & & , \\
\hline OKLAHOMA & $x$ & & $x$ & $x$ & & $x$ & , & & & & . \\
\hline OREGON & & 1 & $x$ & & & $x$ & . & & & . & . \\
\hline PENNSYLVANIA & $x$ & 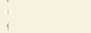 & $x$ & & & 1 & - & & & & $x$ \\
\hline RHODE ISLANO & & $x$ & & & - & & 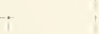 & & & & \\
\hline S CAROLINA & $x$ & ! & $x$ & $x$ & & & . & & & , & , \\
\hline$S$ DAKOTA & $x$ & $x$ & & & & $x$ & $=$ & & & & + \\
\hline TENNESSEE & & t & $x$ & $x$ & $x$ & & + & & & & \\
\hline TEXAS & $x$ & ! & $x$ & $x$ & & & -4 & & & & \\
\hline UTAH & $x$ & : & $x$ & $x$ & & -1 & + & & & & \\
\hline VERMONT & $x$ & & & & & & -1 & & & & \\
\hline VIRGINIA & $x$ & & $x$ & $x$ & & $x$ & & & & & \\
\hline WASHINGTON & & & $x$ & & $x$ & $x$ & + & & $x$ & & $x$ \\
\hline W VIRGINIA & & & & & & & & & $\ldots$ & & \\
\hline WISCONSIN & $x$ & & $x$ & & & $x$ & ? & & -- & & \\
\hline $\begin{array}{l}\text { WYOMING } \\
\text { OIST OF COLUMBIA }\end{array}$ & & $x$ & $x$ & $x$ & & . & + & & $\ldots$ & & \\
\hline
\end{tabular}


of a reduction of the census period to five years in the near future would greatly reduce this inequity.

Motor Vehicle Registration. Motor vehicle registration is another criteria highly correlated with need, with the added advantage that registrations are accurately recorded annually, thus avoiding the disadvantage of the population criteria. Yet this factor tends to short change the urban areas. Because of congestion and the availability of other transportation modes in the cities, the number of motor vehicles per capita in urban areas is fewer than in rural areas, but because of high maintenance and construction costs for city streets, a higher financial need exists.

Fuel Consumption. Many authorities argue that fuel consumption, measured by fuel sales, is the best symptomatic measure of need. Because fuel consumption varies with terrain, increasing with roughness, as well as with urban versus rural operation, construction and maintenance costs and thus financial need are reflected. Unfortunately a measurement of fuel consumption by road classification or government level, is usually difficult to obtain.

Mileage. A commonly used criteria for the allocation of highway user funds is road mileage. Unfortunately road construction and maintenance costs vary greatly with terrain and density of population. There also has been in Indiana disagreement as to the true mileage figures for each unit 
of government. In addition rural areas with their extensive systems of low volume roads are greatly favored over urban areas with their higher volume, higher mileage-cost facilities. Mileage can, however, serve as a reasonable allocation criteria when the population differential is not too great over the sector of distribution.

Area. Area, though often used as an allocation criteria, appears to bear iittie correlation with need other than the possible correlation between area and road mileage.

Assessed Evaluation. The main justification for this criteria is its correlation with population and thus with need. There appears to be little reason for assigning a greater share of funds to areas of higher assessment simply because they are more valuable. A major drawback of this criteria is the difficulty in maintaining a uniform standard of assessment throughout the region. Because property assessment is performed at the local level in Indiana such uniformity would be nearly impossible to obtain.

It can be shown that all of the above criteria do bear a relationship with needs, some better than others. It remains only to find a suitable combination of these factors which best correlate with needs, to establish an equitable distribution formula. 
Present Distribution in Indiana

Indiana's present distribution formula for state collected user revenues distributes 53 percent to the State Highway Commission, 32 percent to the counties, and 15 percent to cities and towns. Indiana distributes highway user funds among the counties in proportion to motor vehicle registration and county mileage, as follows; 5 percent distributed equally, 30 percent distributed in proportion to motor vehicle registration, and, 65 percent distributed in proportion to certified county road mileage. The distribution among cities and towns is directly proportional to population.

A new distribution formula was proposed for distribution between counties and cities by the Needs Study. It proposed distribution first to each county including the share of the cities and towns, and then distribution to each government level within the county, as follows:

To each county including its cities and towns;

80 percent on passenger car registrations,

6 percent on mileage,

, 14 percent equally

within each county;

3 percent of the total to the county government of the remaining 97 percent

87 percent on population,

13 percent on mileage. 
The Needs Study states that the proposed formula would account for between 98 and 99 percent of the variation in the needs, thus there can be little argument with the equity of this recommendation. However one major difficulty is encountered if the present method of fund distribution is revised. Unless considerable additional revenues are obtained (as required to meet total needs), some areas will as a result of the new distribution receive less than they formerly received. Such a reduction while perhaps justified, is certain to generate considerable opposition to any proposed distribution scheme.

\section{Needs Deficit Distribution}

A possible course of action which might minimize public opposition would be the retention of the existing formula for the distribution of present revenues and the implementation of a new distribution formula for any additional revenues. The criteria for distributing these additional funds could again be needs, or alternately, since a portion of the needs would be met by the existing distribution formula, distribution could be in accordance with needs less present distributions or "needs deficit." It can be seen from Figures 16 and 17, however, that needs and needs deficit are highly correlated.

For the purposes of this analysis, needs deficit has been defined as the average annual needs, 1966-1985, for a unit of government, minus the projected average annual 


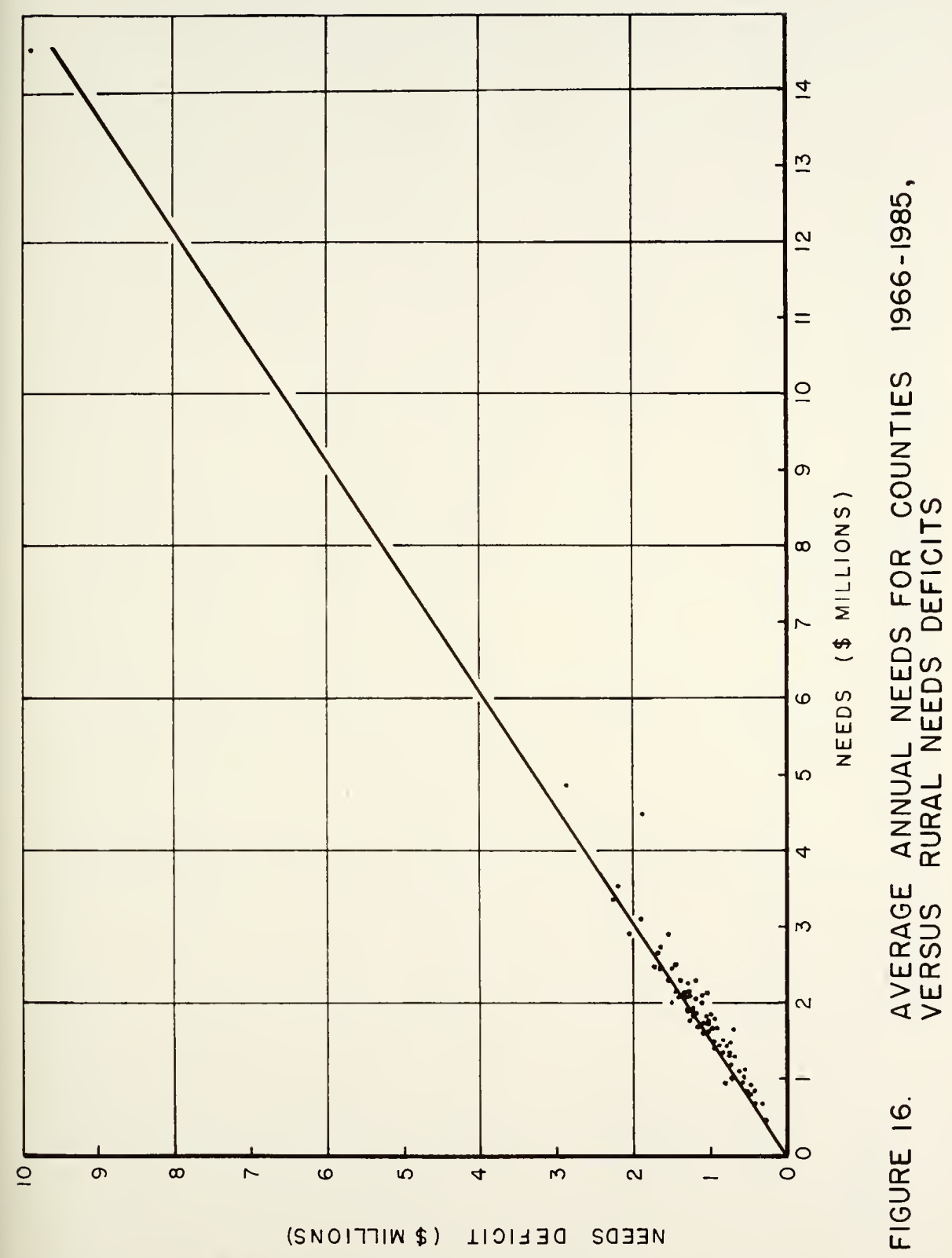




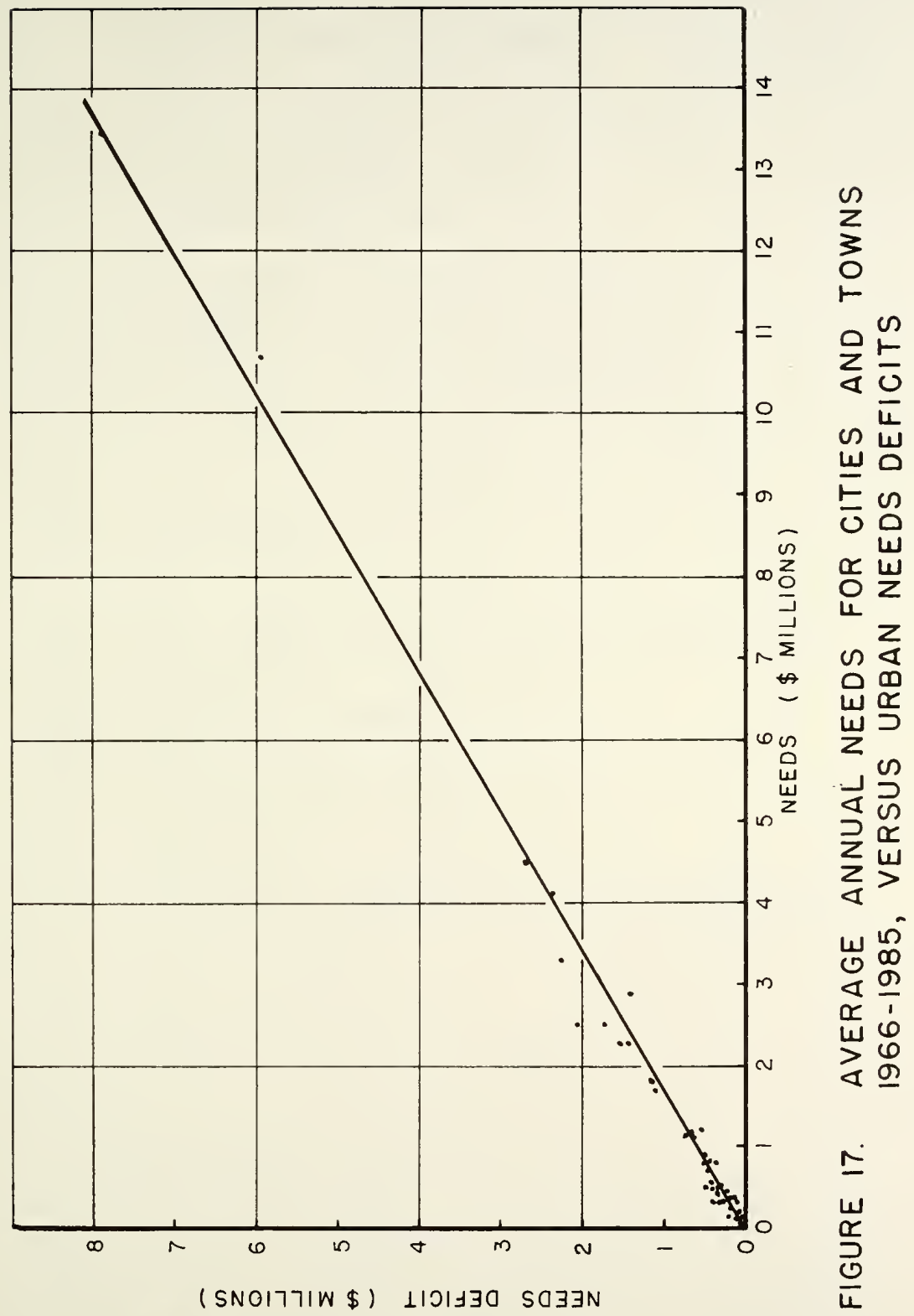


distribution of user funds from.current sources at current values according to the present distribution formula and less Federal Aid maintained at its present level. The average annual needs estimates used are those presented in the needs study "Report on Needs, Appendix Table 7." Estimates of future fund distributions according to the present formula, were made by multiplying the actual 1966 distributions (38, Table 5) by a growth factor representing the estimated growth in revenues to the Motor Vehicle Highway Account.

$$
\begin{aligned}
& U N D_{i}=U N_{i}-\left(G d_{i}+F_{i}\right) \\
& R N D_{i}=R N_{i}-\left(G d_{i}+F_{i}\right) \\
& \begin{aligned}
\text { UND }_{i}= & \text { Urban needs deficit (cities and towns) in } \\
& \text { county } i ;
\end{aligned} \\
& \text { RND }_{j}=\text { Rural needs deficit for county } i \text {; } \\
& \text { UN } N_{i}=\text { Urban needs in county } i \text {; } \\
& \text { RN } N_{i}=\text { Rural needs in county } i \text {; } \\
& \text { G = Growth factor 1966-1985 representing growth in } \\
& =1.0+(212,223-167,484) / 167,484=1.267 \text {; } \\
& d_{i}=1966 \text { fund distribution to county } i \text {; } \\
& F_{i}=1966 \text { Federal Aid to county } i \text {. }
\end{aligned}
$$

\section{Formula Selection}

As previous stated distribution of state highway user funds among levels of government according to factors which most closely agree with needs or needs deficit is desirable. Accordingly the following eight most commonly used factors 
were considered in formula selection:

1. Urban Population, 1960 census,

2. Rural Population, 1960 census,

3. County Area,

4. County Road Mileage, 1967 Inventoried Mileage,

5. County Urban Road and Street Mileage (1966),

6. County Assessed Evaluation (1966),

7. County Motor Vehicle Registration (1966),

8. County Fuel Sales (1966) (actually used were county service station sales taxes).

It was also decided that distribution to the county and urban levels of government should be separated, as is now the case in Indiana, and these separate shares distributed among counties, and among cities and towns according to the best distribution formulas.

To arrive at appropriate equations the above factors were compared with the needs deficit using stepwise linear regression analysis [44]. Many combinations of factors were used but rarely were more than two factors important in any resulting formula. Table 10 lists those formulas which were selected from the many formulated on the basis of their "best fit" to the needs deficit data. Table 10 also included the currently used distribution formulas. For the selected equations the multiple correlation coefficient, $R^{2}$, ranged from a low of 0.84 to a high of 0.98 .

slightly higher correlations might have been achieved by using higher order equations, especially for the rural 


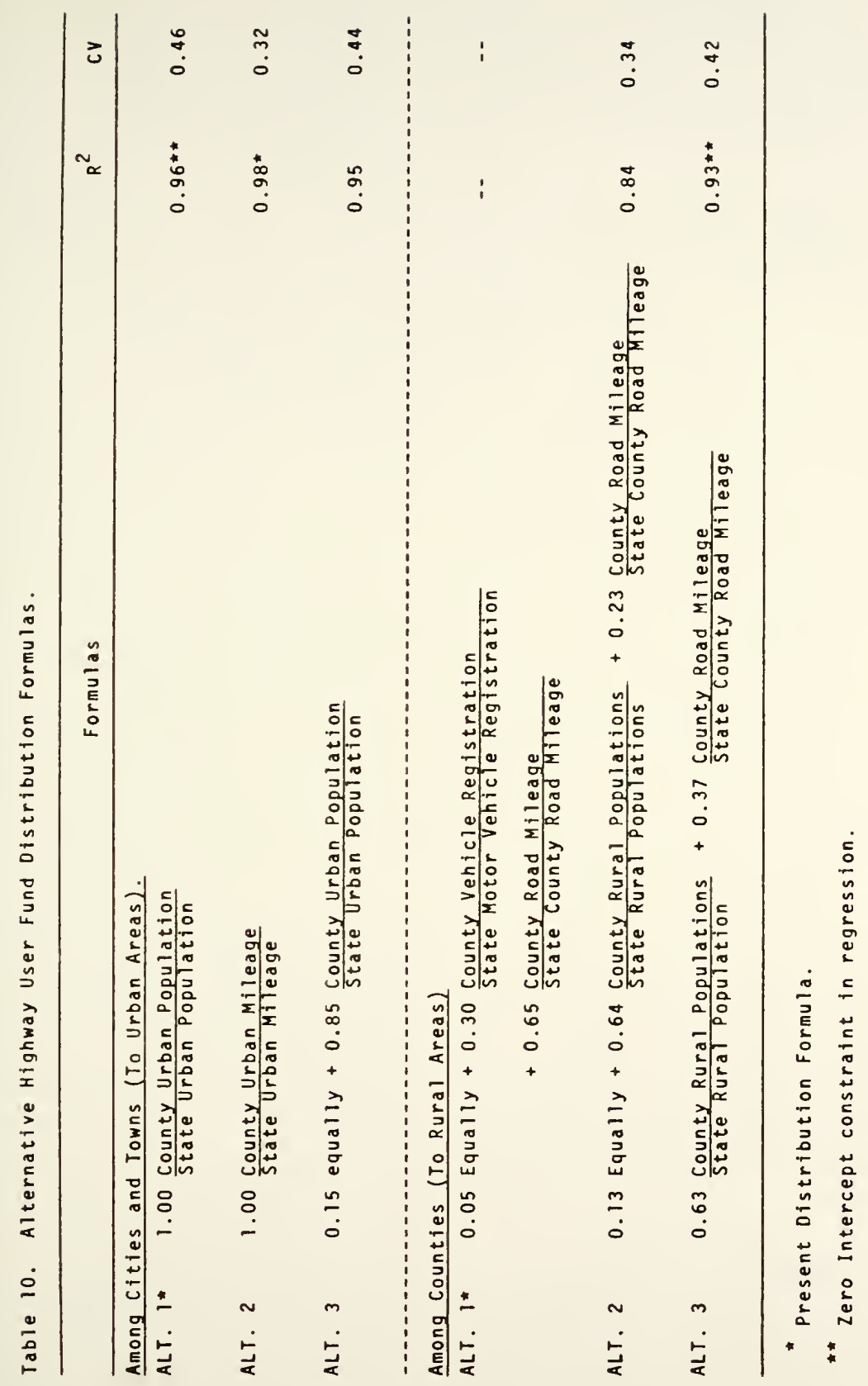


areas. A primary requisite, however, of a distribution formula is that it be understood and accepted by the people. A linear relationship among factors is more understandable than higher order relationships.

Though correlation with needs deficit is the primary factor in the formula selection other less measureable factors must also be considered. For example the symptomatic factors should be readily obtainable, preferably frequentiy updated, and of a nature that there can be little argument as to their validity. For this reason a formula with a lower degree of agreement with needs might prove more satisfactory from the standpoint of administration. The high correlation between motor vehicle registration and population, and between assessed evaluation and population presented in Figures 18 and 19 , suggest that any one of these factors might be easily substituted for the other. These then were the basic criteria used in finally choosing the formulas presented in Table 10.

Appendix A presents actua? distributions to the counties and cities and towns according to each selected distribution formula. The actual dollar distribution given assumes that the total additional funds available for distribution exactly equals the total needs deficit.

\section{Differences Between Needs Deficits and Distribution}

The differences between needs deficits, and the funds distributed according to the selected formulas (Appendix A) are 


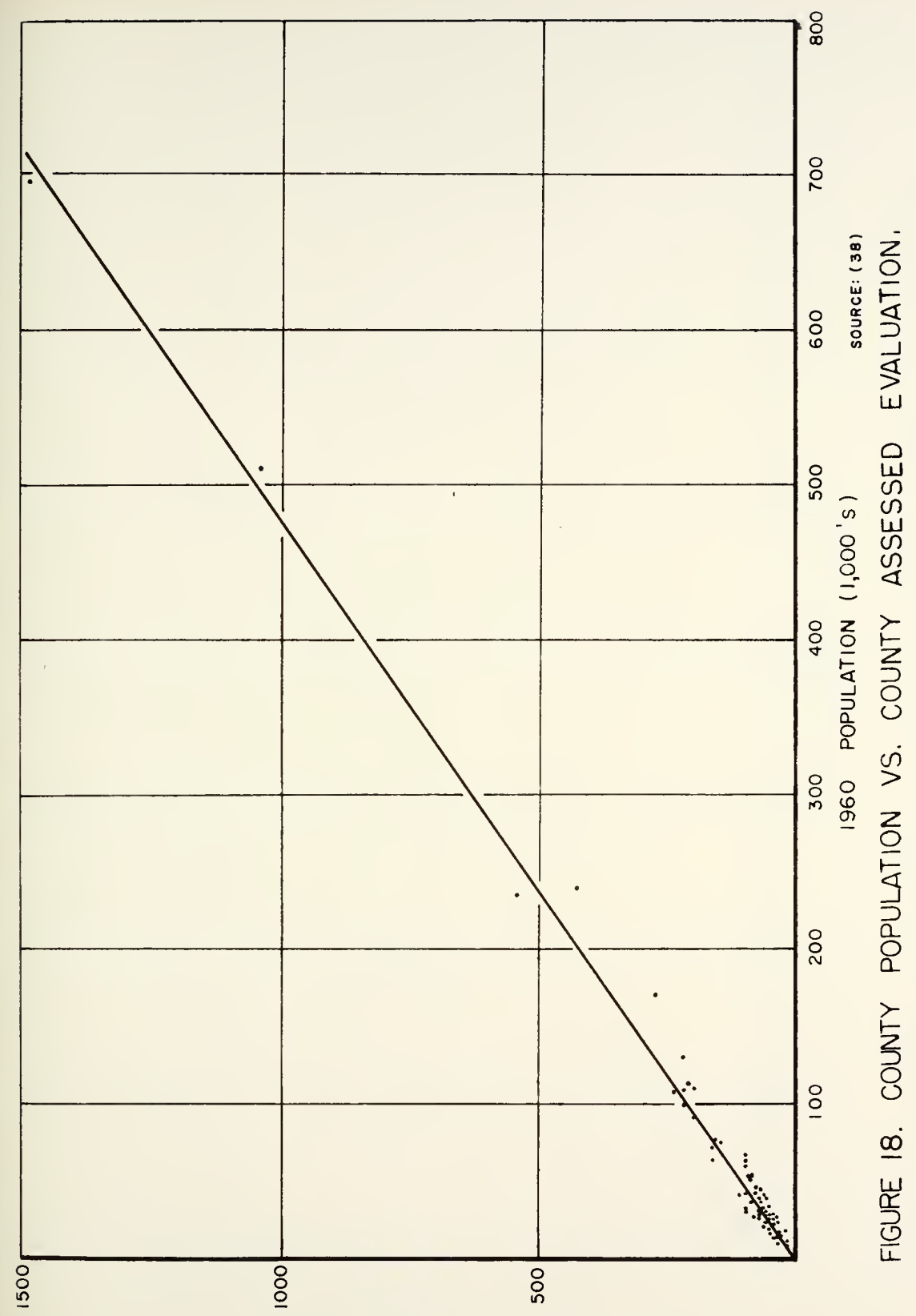

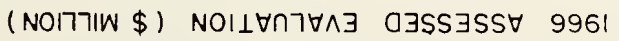




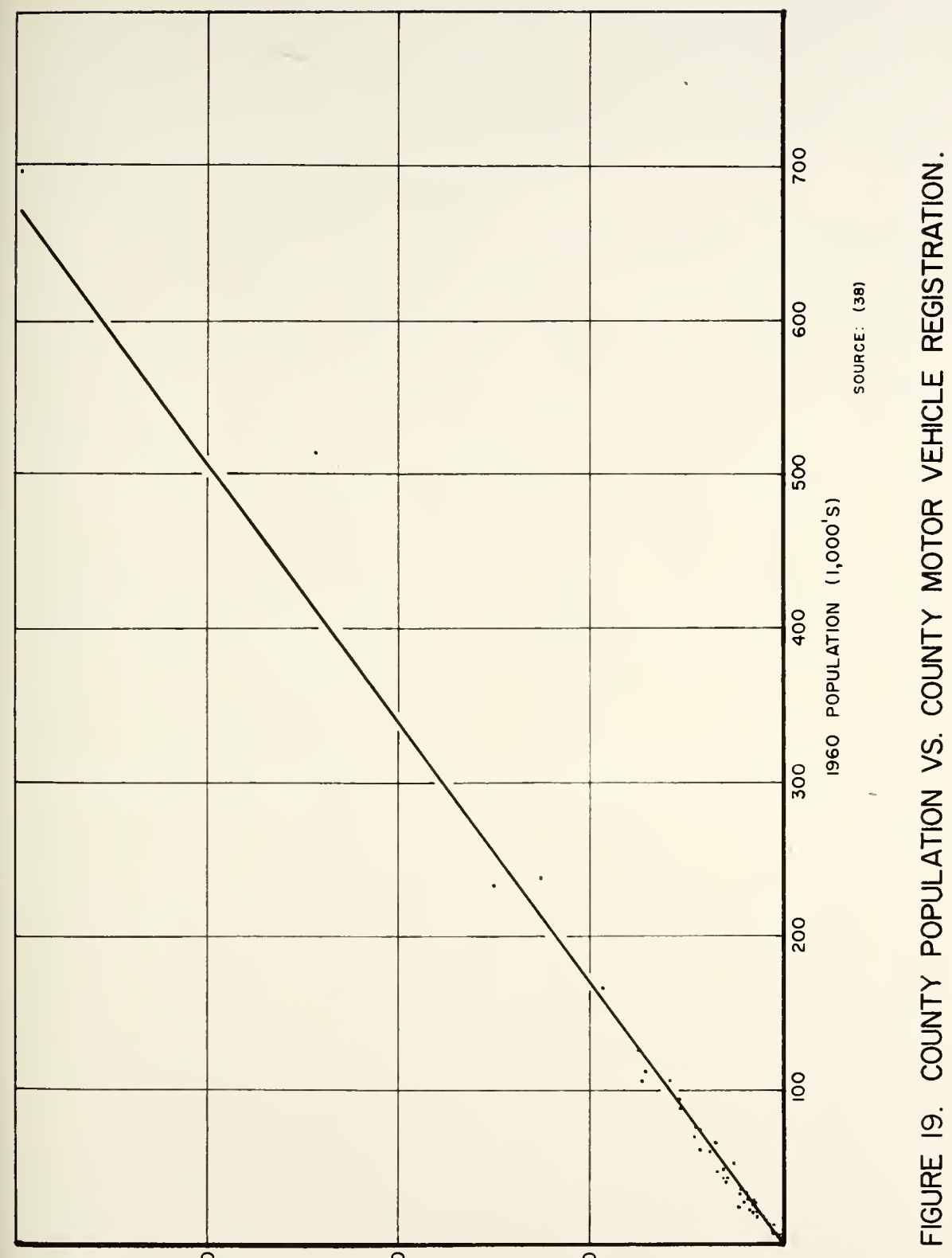

(S,000'I) NOI 
in some cases substantial. Though it is difficult to determine all of the factors contributing to the differences, a major part can probably be attributed to one or a combination of the following factors.

1. Needs as determined by a needs study are subject to numerous human variables in the assessment of the actual needs and deficiencies. Though needs are determined in accordance with an established procedure, it is impossible to eliminate all differences in assessed needs when any opinion is called for on the part of the assessor.

2. The effort made at the local level in the collection of revenues, and the improvement of highways, roads, and streets is not reflected in the selected distribution equations, nor apparently in the distribution formulas as used by other states. Thus a county, city, or town with a well developed improvement program will be reflected in the needs study as having a lower level of need than a county, city, or town with a less adequate improvement program. However, the factors symptomatic of need, such as mileage, population, etc., are still reflected in the distribution formula.

3. The constraint of restricting the distribution formula to a linear combination of factors, results in the generation of equations which do not account 
for as much of the variability in needs as might have been accounted for by higher order equations. 


\section{CHAPTER VI. BOND FINANCING}

\section{Characteristics of Bonding}

Whenever government authorities are faced with the problem of financing highway needs beyond the capabilities of revenues, the decision to support the system on a pay-asyou-go basis, or to resort to credit financing bears critically on the scheduling of improvements and the measures to be taken to finance them. Throughout history, borrowing has been widely used for supporting highway improvement. From as early as 1893 when Massachusetts first borrowed for highway purposes to the present day, all but two states, Arizona and Nebraska, have incurred some form of debt for financing highways. Since 1946 concurrent with the spectacular post war expansion of highways and the era of toll road construction, the long-term highway debt of the states has grown from less than $\$ 1.4$ billion to $\$ 11.8$ billion in 1966 . In 1966 the total highway debt obligations of the states and their political subdivisions amounted to in excess of $\$ 13.1$ billion.

\section{Advantages}

The wise use of debt financing for highways has over the years proved extremely beneficial to the government and the public alike. On the other hand, excessive borrowing 
has placed some states in extremely embarrassing financial positions. The growth in the use of the borrowing instrument has been initiated by government authorities because of the advantages it affords:

1. The major advantage of borrowing is that it allows almost immediate construction of needed facilities. Rather than waiting for the accumulation of annual user receipts, high demand facilities can be put in early service to relieve congestion. As an example the 157 mile Indiana Toll Road was completed in just over two years at a cost of $\$ 280 \mathrm{million}$. It would be difficult to estimate how pay-as-you-go financing could have achieved a similar record in a time anywhere near two years.

2. With the limitations of a pay-as-you-go program it is often necessary to make stop-gap repairs on facilities badly in need of complete reconstruction. Too often the shortage of funds has led to a repaving job where a complete reconstruction is necessary to bring a facility up to modern standards. The report "Financing Kentucky's Roads and Streets" estimated that through borrowing, a total savings of $\$ 34$ milition was obtained by eliminating the need for most of the stop-gap measures [45]. The Needs Study for Indiana estimated stop-gap measures would cost $\$ 166$ million over the 20 year period $1966-$ 1985. Much of this cost could be eliminated if 
funds to make the necessary permanent improvements could be made available at an earlier date. Borrowing is a possibility.

3. Bonding adds a measure of flexibility to the financing of a needs program. Bonds can be sold very early over a few years to afford extensive "catchup" programs with repayment delayed until later years when needs are greatly reduced, or they can be spread over a number of years maintaining a lower but uniform level of construction.

4. Borrowing for highways allows the users to pay for the facility during the period for which they enjoy its use. A pay-as-you-go program requires highway users to pay for a facility several years before they can use it, because of the time lag between revenue availability and completed construction. Highway improvements, because of their long life of approximately twenty years, are enjoyed by users long after they are constructed and paid for by means of pay-as-you-go financing. Borrowing with repayment scheduled over the life of a facility requires a 11 users to pay a share of the cost as they use $i t$, rather than charge users prior to construction.

5. If user costs are included in the analysis, it is claimed that savings in operating costs, time costs 
and accident costs alone will more than be sufficient to cover the interest cost on borrowed funds.

\section{Dangers of Borrowing}

Though the advantages of borrowing are numerous, many states have hesitated, because of deep seated dislike of public debt, to implement extensive borrowing programs. The following statement from a Princeton symposium on highway finance summarizes this feeling:

Debt issues are normally accompanied by tax increases to support the interest and debt redemption payments. Deep seated public prejudices against expanding the size of the government and against new taxes, therefore come to bear upon proposals for new debt financing [46].

In addition to historical prejudices there are other inherent pitfalls of borrowing which have restrained a number of governments.

1. The fundamental criticism of a borrowing policy is the difficulty of drawing a halt once a debt policy is initated. The ease with which funds are obtained sometimes leads to excessive and unjustified expenditures. This problem is well stated by the National Highway Users Conference Inc.; though advocating borrowing as a device for accelerating highway programs, it cautions:

The use of credit financing may be a dangerous tool. The ease of borrowing may lead to the use of this device for projects not economically justifiable 
or beyond the state's ability to

handle without critical impact on

future highway programs [47].

2. Borrowing programs must be based on estimates of future highway user revenues. Once issued there is no turning back on the responsibility of a debt issue and should the revenues prove to be less than estimated the government may find itself having to retire the debt with general tax funds.

\section{Controls}

It is obvious that the decision to implement a borrowing program is not an easy one, and must be made by analyzing the advantages with the potential dangers. Certain guidelines however can reduce these dangers by controlling the use of borrowing and assuring that proceeds are spent most efficientiy.

Above all the projects must be long term with a high present as well as projected demand. The report "financing an Expanded Highway Program in Tennessee" has outiined four primary controls on borrowing policies [16].

1. "Determine the maximum annual amount which the highway department can spend effectively." Scheduling highway improvements over too short a period would overtax the states ability to plan, design and supervise and may lead to inferior results.

2. "Estimate the amount of regular funds which will be available during the year, and issue bonds only 
for the difference." Bonds should not be issued prior to the time the projects are ready to go and should not be greater than the recognized needs.

3. "Assume that the most productive sections of the highway system are constructed first." Those sections which carry the highest volumes should be constructed first. This will assure that the optimum amount of user revenues will be provided to service the bonds.

4. "Set specific limits either on the total amount that may be issued, or the amount that may be outstanding at any one time." This measure, if properly regulated, will preclude over-extension of the governments debt capabilities. One guideline suggested is to limit total indebtedness to a fixed percentage of assessed property evaluation of the state.

\section{Types of Bonds}

The distinction made between the various forms of debt security is a fundamental factor in the analysis of highway borrowing practices, for the means of securing the debt determines interest rates, maturity schedules, and even the ability to borrow at all. There are basically three forms of bonds issued by state authorities -- General obligation Bonds, Limited Obligation Bonds and Revenue Bonds [48]. 
General obligation bonds, also known as guaranteed bonds or full-faith bonds, are obligations guaranteed as to payment of interest and principal by the state or local government selling the bonds. The bonds are secured by the total general taxing power of the government. Limited obligation bonds are secured by a pledge of the proceeds of a specific tax, usually road-user imposts such as motor fuel tax receipts, or revenues of a specific fund. These bonds carry no further guarantee or commitment by the issuing government in the event the pledged revenues prove inadequate to meet debt service. Revenue bonds are obligations to finance alleged self-supporting facilities and are secured only by the tolls and other earnings of the project.

\section{Borrowing by States}

In 1966 total outstanding state obligations amounted to $\$ 11,813,921,000$. Of this total, 22 states had outstanding general bond obligations totaling $\$ 3.062$ billion, 18 states including the District of Columbia had outstanding limited obligation bonds totaling $\$ 3.819$ billion, and 24 states, including Indiana, had outstanding Revenue Bonds totaling $\$ 4.896$ billion.

To prevent excessive and unwise borrowing most states have placed restrictions on the legislature's power to pledge the State's credit against bond issues. The constitutions of 22 states, including Indiana, flatly prohibit borrowing with the usual exceptions such as meeting casual deficits, 
refunding prior debt and defending the state. In these states each proposal involving borrowing must be authorized by a constitutional amendment approved by the electorate. In 17 states, borrowing can be accomplished by approval through a popular referendum of the electorate. In the 11 remaining states, the authority to incur debt is vested in the legislature and popular approval of the electorate is unnecessary.

Interest Rates and Maturity Schedules

As is the case with any form of borrowing, interest must be paid by the bond issuer to the bond holder as compensation for the use of the holders money. Interest rates vary according to the scarcity of money at the time of the bond sale, the anticipated inflationary or deflationary trends in the economy, the length of maturity of the bonds, and the degree of risk which the purchaser assumes he is taking. Over the years the general trend in interest rates for bonds has been upward from between one to two percent in 1945 to approximately four percent in 1966 (see Figure 20). Also significant is the fact that interest charges have run from 1.25 to 1.5 percent higher for revenue bonds as opposed to general obligation bonds, and as much as 1.0 percent higher than limited obligation bonds, reflecting the bond purchasers opinion of the risk involved with each type of bond issue.

Revenue bonds are usually issued as term bonds; that is they mature on a fixed future date and are redeemed from 


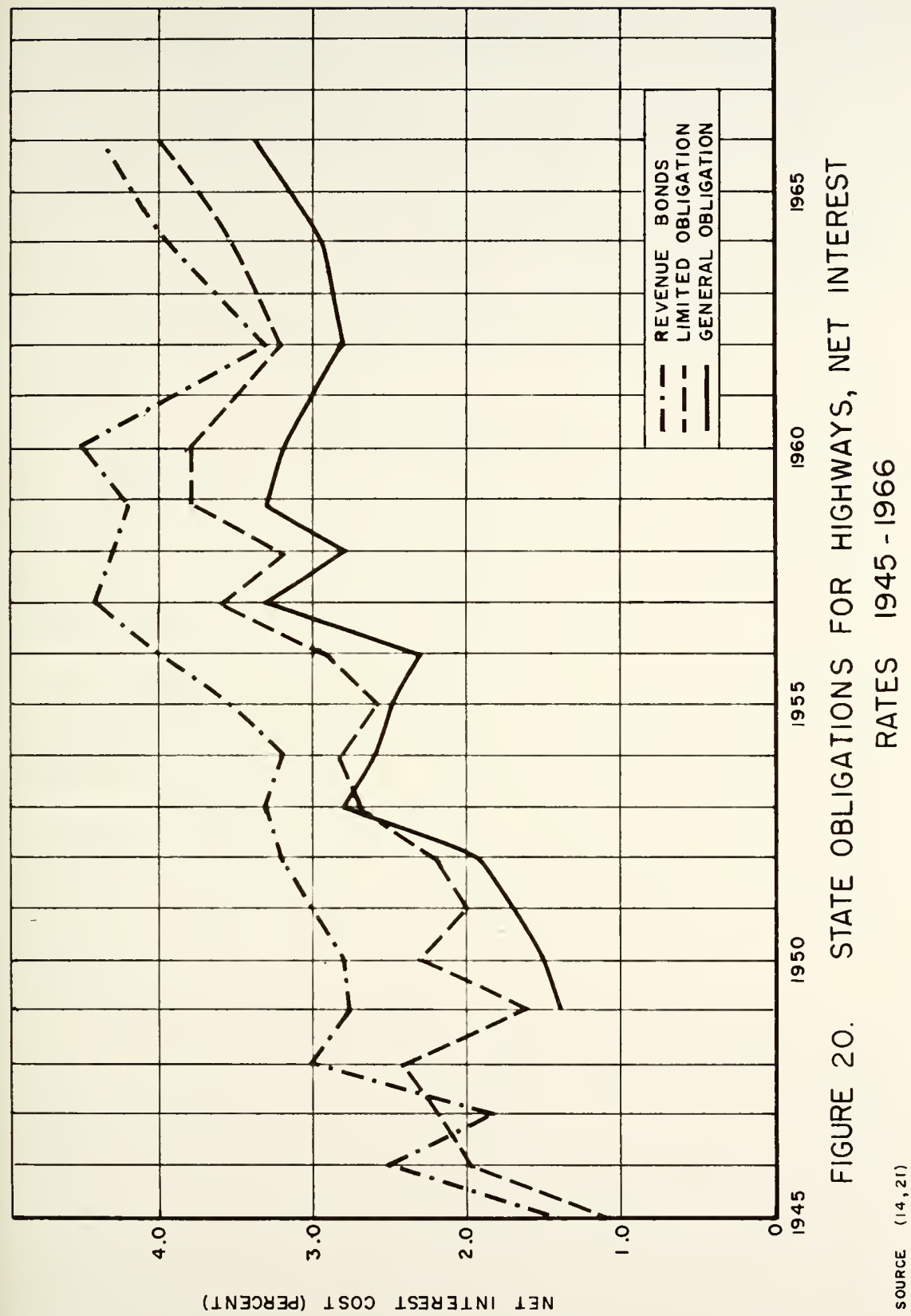


from the accumulations of a sinking fund. The term may vary from 10 to 50 years. In recent years the terms have been between 35 to 40 years. General and limited obligation bonds are usually issued as serial bonds; that is the principal is retired on an annual schedule and the interest payments decline as the loan is amortized. Maturity dates for these bonds average approximately 25 years.

\section{Inflation and Costs}

Irrespective of the use of debt or pay-as-you-go financing, revenues for financing needs must be obtained. Borrowing may afford accelerated reconstruction but in the long run the same number of dollars must be collected. In fact a major criticism of borrowing is that this device only increases the total dollar requirements because of the added interest costs. At first glance this appears to be a logical criticism; however the changing nature of the economy such as inflation, deflation, or changes in construction costs can have a profound influence on the real cost of borrowing.

Modern economic theory dictates that a powerful progressive economy must be accompanied by mild inflation [49]. Inflation has been with us in the past and will likely continue to be an integral part of economic growth. There are two types of price increases often referred to under the name of inflation. However there is a difference. True inflation may be defined as an increase in the general level 
of prices and income throughout the economy. The second form of price increase is differential price changes defined as the difference between the price trends of the good or service being analyzed and the general price trends.

There are basically two causes of inflation: 1) The demand for goods and services increases more than the available supplies; and 2) Wage increases exceed increases in labor productivity.

\section{Indices of Price Trends}

There is no single perfect measure of price trends. The three indices most commonly used are the consumer Price Index, the wholesale Price Index and the Gross National Product Deflator (see Figure 21 ). In the analysis of price trends, past and projected, it is customary to look at all three in combination. A brief description of each index follows.

Consumer Price Index. This index measures the average change in prices of approximately 300 goods and services purchased by city wage-earner and clerical-worker families. The quantities and qualities of the items included remain the same between consecutive pricing periods, so that the index measures the effect of price change only on the cost of living of these families. The items priced are described by detailed specifications to insure, as far as possible, the same quality each time, and that differences in reported prices are measures of price change only. 


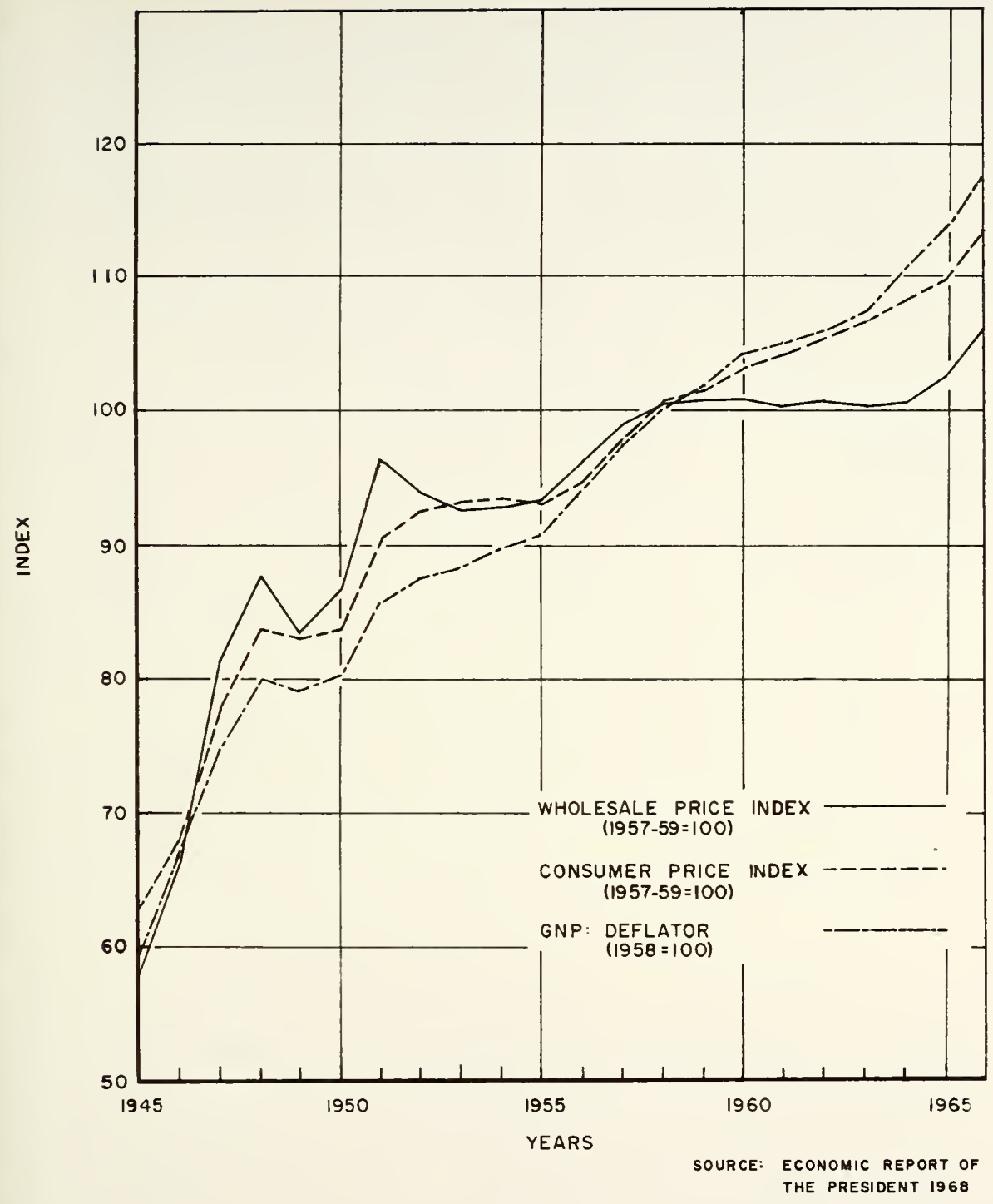

FIGURE 21. GENERAL PRICE TRENDS IN THE UNITED STATES, 1945-1966 
Wholesale Price Index. This index, prepared by the Bureau of Labor Statistics, is designed to measure average changes in prices of commodities sold in primary markets in the United States based on nearly 2,200 commodities.

Gross National Product Deflator. The U. S. Department of Commerce has combined a number of price indices to measure price changes in G.N.P. from year. to year known as implicit price deflators. Price changes in the highway field have best been described by the U. S. Bureau of Public Roads Highway Cost Index which measures and records the various component costs for Federal-Aid highway construction (see Figure 22).

It is apparent that the reducing effect on the dollar value caused by inflation favors borrowers at the expense of lenders. A debtor borrowing money now to spend now repays this fixed dollar debt with dollars of reduced value.

\section{Borrowing for Indiana - A Case Study}

To study the affect which price increases and inflation might nave nad on a borrowing policy for Indiana, the major highway construction projects awarded in fiscal year 1946 were studied (see Table 17 and Figure 23). Though these projects were in fact constructed, it is assumed that if sufficient additional funds from borrowing had been available, 27 additional similar projects would have been initiated. We therefore may assume these constructed projects to be 

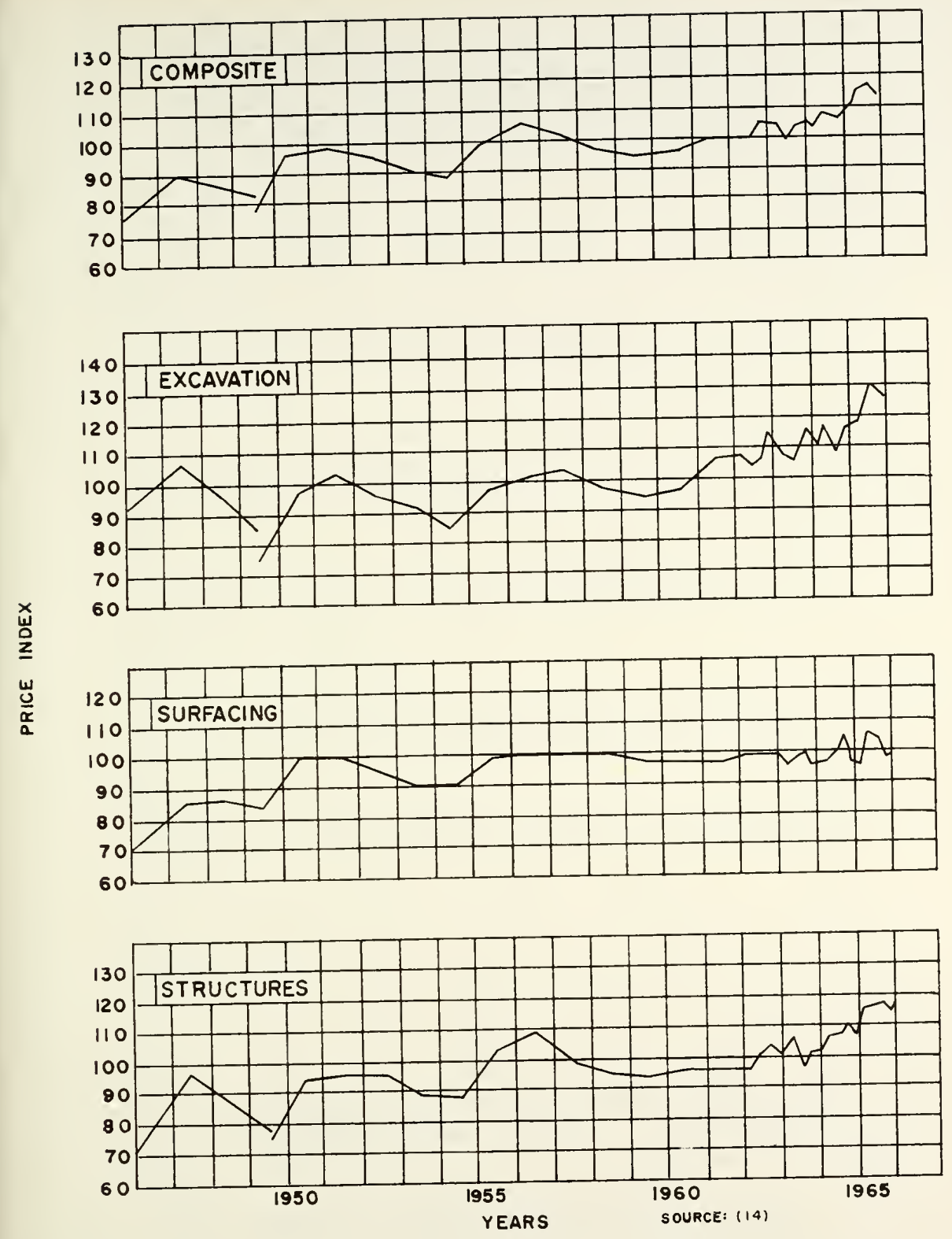

FIGURE 22. PRICE TRENDS FOR FEDERAL-AID HIGHWAY CONSTRUCTION, 1946-1966 $\left(1957^{-}-1957=100\right)$ 


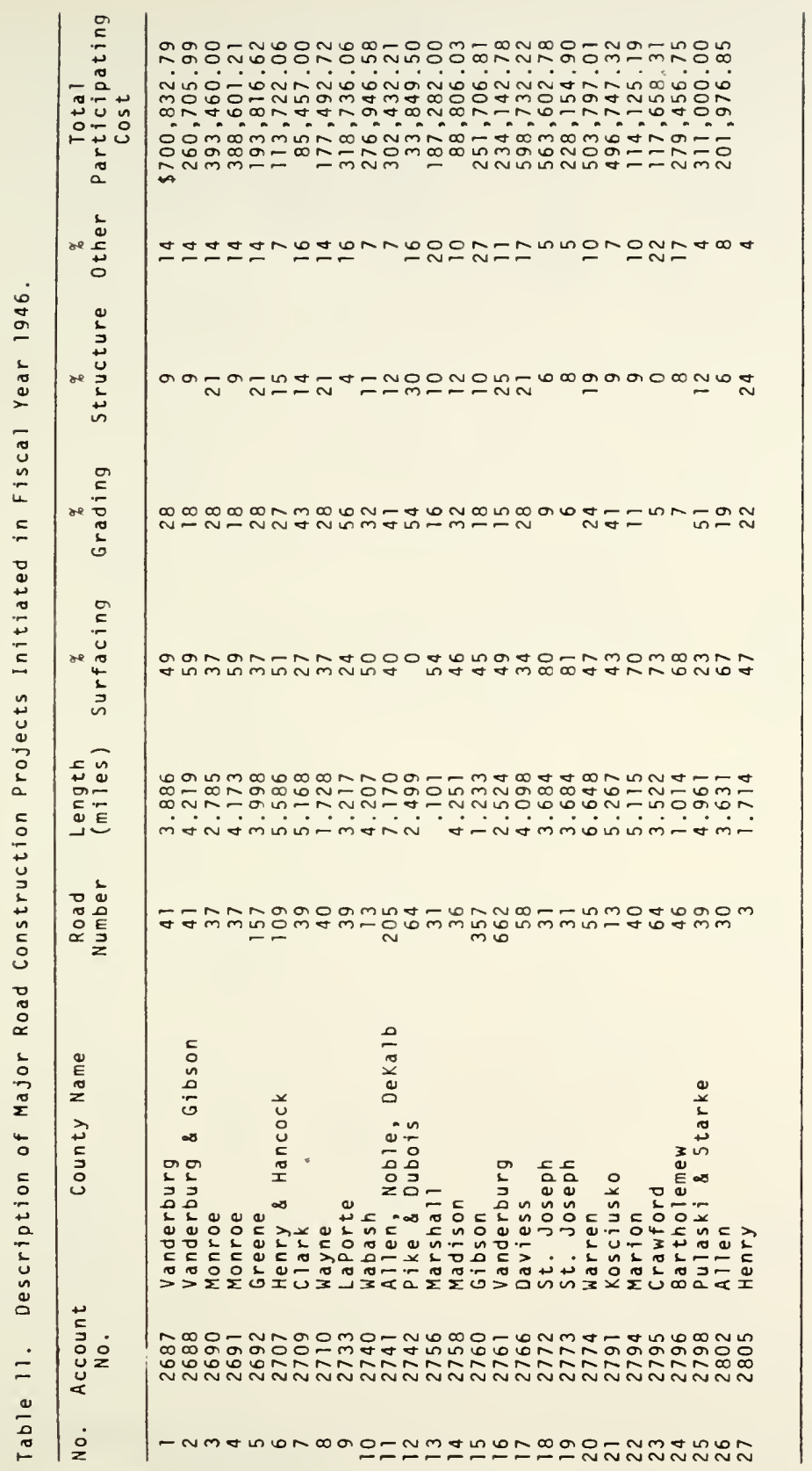




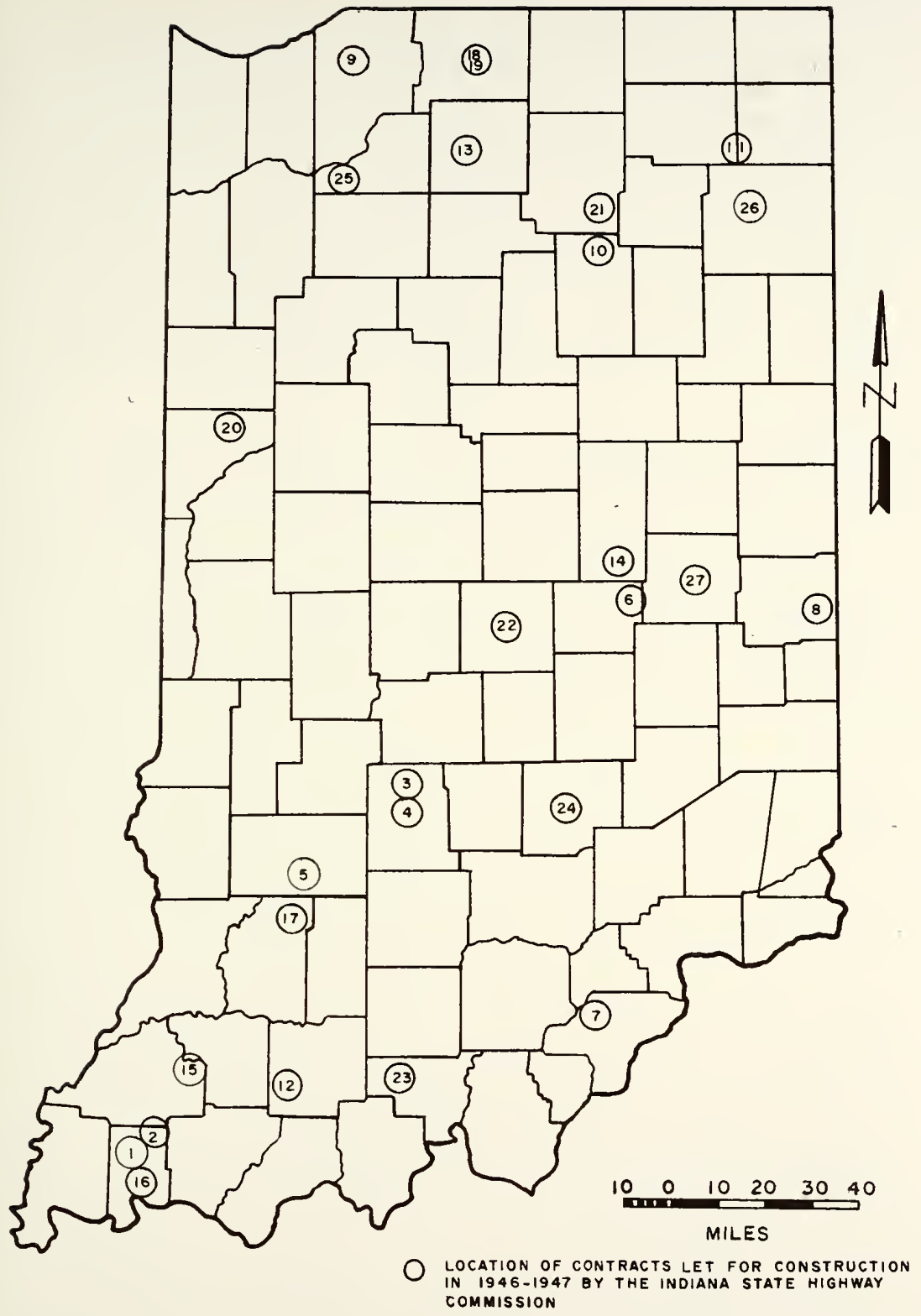

FIGURE 23. LOCATION OF CASE STUDY CONSTRUCTION PROJECTS 
representative of additional projects which might have been awarded had funds been available. In this manner the cost of borrowing for additional construction may be evaluated in comparison with price increases. If we also assume that the past is a good indicator of the future this comparison might suggest the costs or savings of borrowing now or in the future for highways, as opposed to pay-as-you-go financing.

In such a comparison the cost of borrowing, that is the interest rate, must be weighed against the differential price changes in construction costs, the affect of inflation on the debt service payments, and the user and non-user benefits accruing to the public from the improvement or existence of a highway facility. As it is the purpose of this study only to investigate means of paying for highways, benefits derived from having the facilities at an earlier date, many of which are often non-monetary in nature, will not be considered. It is however realized that these benefits play an important part in the final analysis.

Should construction costs increase relative to other costs, then it is obvious that accelerated construction will result in a savings; however should costs decrease, a loss will be incurred. Inflation can also influence borrowing. For example if a sum was borrowed ten years ago to be repaid annually over a ten year period and during that period inflation had forced prices to increase, then each annual 
payment would have a reduced purchasing power. In effect the money repaid, excluding interest, in terms of real purchasing power would be less than the sum initially borrowed.

For the 27 selected projects constructed in 1946-1947, the construction costs were divided into four categories, grading, surfacing, structures and other (see Table 11). For each project and each category the 1946 costs were factored to 1966 costs, using the Bureau of Public Roads construction cost indices. During this period the overall construction costs increased 51 percent, or for the 27 projects from approximately $\$ 8.5$ million to $\$ 12.7$ million. Combining the Gross National Product Deflator, the Consumer Price Index, and Wholesale Price Index, a 51 percent increase in overall prices also took place over the same period. Thus we may assume that increases in overall highway construction costs have been due entirely to inflation and not due to differential price changes.

This inflationary trend has averaged approximately 2.08 percent (compound rate) per annum and might be considered as a negative interest rate on borrowing in that each year the real purchasing power of the debt repayment is reduced by 2.08 percent.

Balanced against the inflation of the dollar is the net interest rate for borrowing. As discussed earlier this interest rate depends on the form of bonding employed, 
general obligation, limited obligation, or revenue. In 1946 the average cost of borrowing for highways for general obligation bonds was 1.75 percent and for limited obligation bonds 2.0 percent. Based on each of these interest rates the cost of borrowing for each type of bond has been compared in Table 12, with the affects of inflation for 10, 15, and 20 year bond issues.

From these results it can be seen that for general obligation bonds, a net savings would have been incurred on the short terms with a net cost for the longer term. Similarly for the limited obligation bonds, the short term appears more favorable. However, the net cost of borrowing even for 20-year bonds, in both cases, is very small. If roads user benefits received for accelerated construction as opposed to pay-as-you-go construction, had also been included, the savings as a result of borrowing would be substantial.

Many observers feel that an annual rate of inflation of no more than two percent can be tolerated [49]. One might therefore assume that inflationary pressures balanced by government controls will tend to maintain this rate in the future. It is also likely that the past trends in construction costs will continue into the future. On this basis a comparison between the cost of borrowing in 1966 at interests rates of between 4 to 5 percent with the gain due to 2 percent annual inflation would result in a net cost for borrowing 


\begin{tabular}{|c|c|c|c|c|c|c|c|c|c|c|c|c|}
\hline & & $c$ & & & & & & I & & & & \\
\hline & & & & & or & $\infty$ & & i & & & & \\
\hline & 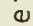 & & & & 0 & $\sim$ & & i & & 0 & & \\
\hline & $z$ & 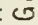 & & & $=$ & - & & $i$ & & 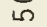 & & \\
\hline & & & & & & & & 1 & & & & \\
\hline & & & & & & & & 1 & & & & \\
\hline & + & in & & & & & & 1 & & & & \\
\hline & 0 & 0 & & & & & or & $i$ & & & - & or \\
\hline & $z$ & 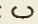 & - & & & & $\theta$ & i & & & $m$ & in \\
\hline & & & & & & & & 1 & & & & $N$ \\
\hline & & & & & & & & i & & & & \\
\hline - & & & & & & & & 1 & & & & \\
\hline$\sim$ & & & & & & & & 1 & & & & \\
\hline 0 & & $\omega$ & & & & & & $i$ & & & & \\
\hline 0 & & $=$ & & & & & & 1 & & & & \\
\hline 0 & & $\underline{(}$ & & & & & & 1 & & & & \\
\hline 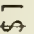 & & $\frac{E}{d}$ & 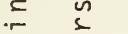 & & r & $N$ & a & $i$ & & 0 & $m$ & or \\
\hline E & - & 2 & to & & or & $\pi$ & $\Leftrightarrow$ & $i$ & & 50 & $m$ & Ln \\
\hline & r & .7 & $+6-$ & & $m$ & $m$ & (n) & $i$ & & $\sigma$ & in & $N$ \\
\hline$=$ & + & + & $\backsim \sigma-$ & & n & n & a & I & & n & n & n \\
\hline 0 & 0 & 4 & $0 \sigma, 0$ & & $\infty$ & $\infty$ & $\infty$ & i & & $\infty$ & $\infty$ & $\infty$ \\
\hline$\cdot r$ & $\vdash$ & $\propto$ & $\omega-\sigma$ & & & & & $i$ & & & & \\
\hline+ & & & & & & & & $i$ & & & & \\
\hline$u$ & & & & & & & & 1 & & & & \\
\hline$\exists$ & & & & & & & & 1 & & & & \\
\hline 2 & & & $n$ & & & & & $i$ & & & & \\
\hline 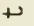 & 0 & & t 6 in & & & & & i & & & & \\
\hline$n$ & or & 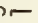 & 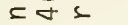 & & & & & $i$ & & & & \\
\hline$=$ & ro & $\pi$ & ब $\sigma$ & 201 & or & $\infty$ & $N$ & $i$ & & เ & $\sigma$ & $\infty$ \\
\hline$\overline{0}$ & $\delta$ & 3 & $E--$ & in & $m$ & L & $N$ & $i$ & de & $\theta$ & 6 & $m$ \\
\hline$\omega$ & a & 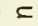 & $\rightarrow-$ & $N$ & $\infty$ & ᄂ) & $\sigma$ & I & 0 & $\infty$ & n & $\sigma$ \\
\hline & $>$ & $\bar{E}$ & $\pi=0$ & 1 & & & & i & . & & & \\
\hline$\rightarrow$ & 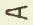 & 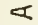 & $a \cdot-\sigma$ & - & & & & $i$ & $N$ & & & \\
\hline ro & & & & & & & & 1 & & & & \\
\hline 3 & & & & $\backsim$ & & & & $i$ & $\backsim$ & & & \\
\hline$\vec{c}$ & & & & 0 & & & & $i$ & 0 & & & \\
\hline or & & & & $\bar{z}$ & & & & $i$ & $z$ & & & \\
\hline$=$ & & & & 0 & & & & I & 0 & & & \\
\hline$I$ & & & $n$ & $\infty$ & & & & $i$ & $\infty$ & & & \\
\hline & & & 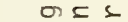 & & & & & 1 & & & & \\
\hline$\omega$ & & e & $=00$ & $z$ & & & & 1 & $z$ & & & \\
\hline$\neq$ & & $E$ & $r \cdot r-$ & 0 & & & & I & 0 & & & \\
\hline o) & & (U) & $\nabla \omega-$ & $\sqsubseteq$ & 0 & $\infty$ & $N$ & 1 & $=$ & $m$ & $m$ & $N$ \\
\hline - & - & s & 300 & $\vdash$ & $\sigma$ & $m$ & $\sigma$ & 1 & $\vdash$ & 6 & $N$ & 0 \\
\hline & $\sigma$ & $\cdot r$ & $+=-0$ & 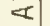 & $m$ & $N$ & 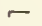 & $i$ & 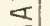 & $\sigma$ & or & $m$ \\
\hline 2 & $\omega$ & & $\backsim \cup_{4}$ & $\Xi$ & n & a & a & $i$ & 0 & a & a & ? \\
\hline 0 & 0 & 0 & $0 \times \leq=$ & $=$ & on & or & 0 & i & $\varpi$ & a & on & 0 \\
\hline 4 & $\vdash$ & $\alpha$ & ひ山. & -1 & & & $=$ & i & $\rightarrow$ & & & $=$ \\
\hline & & & & $\infty$ & & & & $i$ & $\bar{\infty}$ & & & \\
\hline 0 & & & & 0 & & & & i & 0 & & & \\
\hline$E$ & & & $\backsim$ & & & & & i & & & & \\
\hline a & & & $\omega \backsim$ & $ـ$ & & & & 1 & $\infty$ & & & \\
\hline - & & - & $=1$ & 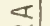 & & & & 1 & $\omega$ & & & \\
\hline & - & $\pi$ & (1) & $\alpha$ & 0 & の & $N$ & $i$ & $F$ & - & $\sim$ & 0 \\
\hline 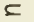 & $\pi$ & 5 & $E \leftarrow$ & w & $\sigma$ & $\checkmark$ & 0 & I & $\curvearrowleft$ & $\sigma$ & 6 & $N$ \\
\hline •r & $\supset$ & & & $z$ & o) & $\omega$ & 5 & i & $\Sigma$ & on & 6 & in \\
\hline & $\sigma$ & $E$ & ro 0 & س & & & & i & $\curvearrowleft$ & & & \\
\hline or & 山 & $\bar{\alpha}$ & 00 & (E) & & & & $i$ & إ & & & \\
\hline$=$ & & & & & & & & 1 & & & & \\
\hline 5 & & & & & & & & 1 & & & & \\
\hline 3 & $=$ & & & & & & & I & & & & \\
\hline 0 & 0 & & & & & & & 1 & & & & \\
\hline$\leqslant$ & $\cdot-$ & 6 & & & & & & 1 & & & & \\
\hline 1 & + & $\sigma$ & & & & & & i & & & & \\
\hline 0 & $u$ & on & & & 0 & 0 & 0 & 1 & & $0^{\circ}$ & 0 & 0 \\
\hline$\infty$ & 3 & $\sigma$ & & & 0 & 0 & 0 & $i$ & & 0 & 0 & 0 \\
\hline & s & & & & م) & $\Omega$ & in & I & & in & 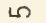 & 5 \\
\hline 4 & $\omega$ & \& & & & $n$ & $\because$ & $a$ & $i$ & & $n$ & n & a \\
\hline 0 & $\backsim$ & $\omega$ & & & $\infty$ & $\infty$ & $\infty$ & $i$ & & $\infty$ & $\infty$ & $\infty$ \\
\hline & $=$ & $\sim$ & & & & & & I & & & & \\
\hline$\omega$ & 0 & 0 & & & & & & 1 & & & & \\
\hline n & U & $\omega$ & & & & & & $i$ & & & & \\
\hline 0 & & & & & & & & $i$ & & & & \\
\hline ن & & & & & & & & i & & & & \\
\hline & 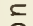 & I & & & & & & 1 & & & & \\
\hline & 0 & $>$ & & & & & & 1 & & & & \\
\hline • & $\cdot r$ & $\omega$ & & & & & & 1 & & & & \\
\hline$N$ & $\omega$ & $r$ & & & $\sim$ & $\sim$ & $\sim$ & 1 & & $\sim$ & $\sim$ & $\sim$ \\
\hline- & a & $-s$ & & & s & 2 & < & $i$ & & i & 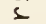 & \& \\
\hline & $r$ & 3 & & & To & $\bar{\sigma}$ & $\bar{\sigma}$ & $i$ & & $\bar{\sigma}$ & $\bar{\sigma}$ & Ta \\
\hline (1) & 2 & $\omega$ & & & 4 & (1) & $\theta$ & i & & 0 & e & (1) \\
\hline- & $u$ & 0 & & & $\lambda$ & $>$ & $\lambda$ & 1 & & $\lambda$ & $>$ & $>$ \\
\hline مـ & $\sim$ & $\sum$ & & & & & & 1 & & & & \\
\hline ro & 0 & $己$ & & & 0 & (n) & 0 & 1 & & 0 & L & 0 \\
\hline$\vdash$ & 0 & & & & $=$ & - & $\sim$ & $i$ & & $=$ & 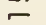 & $\sim$ \\
\hline
\end{tabular}


of 2 to 3 percent, when compared to the slower pay-as-yougo method. However this net cost would be considerably less than the interest costs, and benefits to motorists and the public from having the highway facilities much earlier, undoubtedly would be greater than such costs.

The decision to utilize borrowing for accelerating construction is a difficult one, often based on many intangible factors. A decision should not be made upon the results of a single analysis, such as the above. However when evaluating all the factors, a knowledge of the true cost of borrowing including inflation is necessary to permit a wise decision. 
CHAPTER VII. FINANCIAL PLANNING

A necessary and integral part of a highway finance study is the systematic planning and determination of future financial needs as they are related to physical needs. Only with a realistic evaluation of future highway needs as to time of need as well as cost, can a correct assessment be made of the steps necessary to eliminate these needs.

\section{Determining the Needs}

The appraisal of future project needs is generally achieved by classifying each highway section as acceptable, tolerable or deficient. These classifications are made on the basis of a comparison of the standard and condition of each roadway section with respect to physical condition, safety and traffic service rendered, with a predetermined desirable standard for each roadway classification.

Tolerable conditions refer to roadway sections which fall below the preset standard but are of a sufficiently high standard to not warrant major reconstruction. Deficient sections can be classified into two categories: those sections falling significantly below tolerable conditions at the time of the appraisal, generally referred to as backlog needs, and those sections which meet the tolerable conditions at 
the time of the appraisal but fall below these conditions at some future time during the needs period.

\section{Cost Components}

Estimates of the costs of future needs is facilitated by the identification of the major cost components; construction needs, stop gap needs, replacement needs, and maintenance and administration needs.

Construction. Estimates of the costs for engineering right-of-way, grading, structures, and surfacing are made based upon past experience and estimates of future cost variations for roadways constructed in accordance with the specified design standards.

Stop gap. Because the backlog of deficiencies generally far exceeds the limitations of revenue and manpower, several years are usually required to eliminate the backlog deficiency. Consequentiy critically needed improvements must be deferred into the future. The deferral of these improvements results in excessively high maintenance costs, extensive surface repairs, and special signing and traffic control at particularly hazardous sections; these deferral costs are referred to as stop gap costs.

Replacement. Though roadways sections once reconstructed generally have a life in excess of the study period, practice has shown that some sections fail prior to their estimated 
design lives. A contingent allowance is thus usually made to provide for replacement of some sections which prematurely become inadequate.

Maintenance. To keep the roadway system continually in a serviceable condition, provision must be made for its maintenance and repair. The importance of the maintenance function necessitates that it be funded first, prior to the funding of capital improvement needs.

Administration. The costs of planning, managing, and overseeing the operations of a highway system are generally classified as administrative overhead.

\section{Nature of Continuing Needs}

It is evident from the previous discussion that the formulation of a financial plan can be divided into two parts; the catch-up plan; namely the provision for the elimination of the backlog deficiencies in the shortest possible feriod of time; and the continuing plan, to provide for continuing and future needs deficiencies as they occur.

Continuing needs because they are relatively uniform and do not vary drastically from year to year are well suited to a financial plan based upon revenues derived from user and public taxes. User taxes in turn, because they represent nighway use,also tend to parallel continuing need. Consequently as vehicular travel increases and thus increase need, revenues also increase. 
Catch-up needs on the other hand must be resolved over a short time period to minimize the losses to the user and society through high road-user and accident costs, and regional development restrictions presented by an inadequate road system. Unfortunately because of the limitations of revenues and manpower these needs often must be spread out over a number of years. Ideally, backlog needs should be eliminated in such a manner as to prevent the recurrence of a needs backlog in the future. The difficulty lies in the fact that highways suffer from a limited life, generally approximately twenty-years. If for example the objective of eliminating the present backlog within one year could be achieved, the need would again reoccur when the facilities again became deficient, in other words in about twenty years. Admittedly the recurrence of the needs would be spread out over more than one year but they would still peak in excess of the level of continuing needs after about 20 years. On the other hand, if the backlog is eliminated at a slower pace over a greater number of years the peaking effect is considerably reduced.

A catch-up program spread out over a relatively long period of time, perhaps approximating the average roadway 1 ife, because of its uniform nature, would appear well suited to a pay-as-you-go method of financing. That is with a uniform increase in taxes the needs could be satisfied. On the other hand a short catch-up period of several years 
would require, if pay-as-you-go financing were to be retained, a drastic increase in taxes initially and then at the end of the catch-up period a similar decrease in taxes. One solution to this problem would be the credit financing device as discussed in the previous chapter. During the period of peak needs added funds could be borrowed and then after the catch-up program the excess revenues from taxes could be used to retire the debt incurred. By this device the total capital costs would admittedly be somewhat increased by interest charges, however the savings in the use of the improved facility, improved much earlier than would otherwise have been possible, should be substantially more than the resulting interest charges.

\section{Financial Planning in Indiana}

Indiana, in light of the findings of the highway needs study, is faced with a future need for highways far outstripping available revenues. In terms of total dollars this deficit amounts, as previously stated, to $\$ 187$ million annually over the next twenty years. The decision makers of the state are now faced with the problem of formulating a program to provide for these improvement needs. The courses of action available to them can be resolved into one of jour programs:

1. A no-change program wherein the needs study findings are ignored. 
2. A 20-year.pay-as-you-go program with revenue increases sufficient to satisfy at least a part of the specified needs.

3. A 20-year pay-as-you-go catch-up program with revenue increases sufficient to satisfy all of the specified needs.

4. A catch-up program of less than 20 years to satisfy the needs backlog in a minimum of years, requiring both a revenue increase, and in all likelihood the institution of a borrowing program.

To determine the annual financial requirements and the resulting elimination of needs for each of the above programs, it was first necessary to determine the total annual needs and revenues for each year of the study period 1966 to 1985 .

\section{Annual Needs 1966-1985}

The twenty year highway needs for Indiana were developed by the Indiana Highway Needs Study as previously discussed. Backlog and continuing construction needs were broken down in the Needs Study into five year increments for the three selected road systems; the Selected State Highway System, the Selected County Road System and the Selected Urban Arterial system.

Although the Needs Study recommended that the responsibility for Indiana's highways, roads and streets should ultimately be according to the proposed Selected Highway 
Systems, it recognized that a transition period would be required for making the recommended responsibility transfers. For the period 1966-1985 the Needs Study assigned the cost responsibilities for each of the Selected systems according to the present jurisdictional responsibility, adjusted by a transfer of a part of the construction costs to the recommended levels of government. The resulting breakdown of construction cost responsibilies for 1966-1985 for each of the Selected systems was determined and is presented in Table 13. With this breakdown and the Needs Study assignment of needs by five year periods (Reference 3, Tables 9 , 17, 22) for the selected systems, it was possible to determine the actual construction cost responsibility for each government level for each year of the period 1966-1985 for the selected systems. The needs for local access roads were available from the Needs Study only as average annual needs (Reference 3, Table 28), and these needs were added to the Selected system construction cost responsibility for the local levels of government. To these total construction needs were added estimates of maintenance, administration, stop gap, and replacement needs.

Annual Maintenance Costs though dependent on the total mileage and age of roadway, as well as ground and climatic conditions, were assumed to be equal to the estimated average annual maintenace costs as estimated by the Needs Study. 


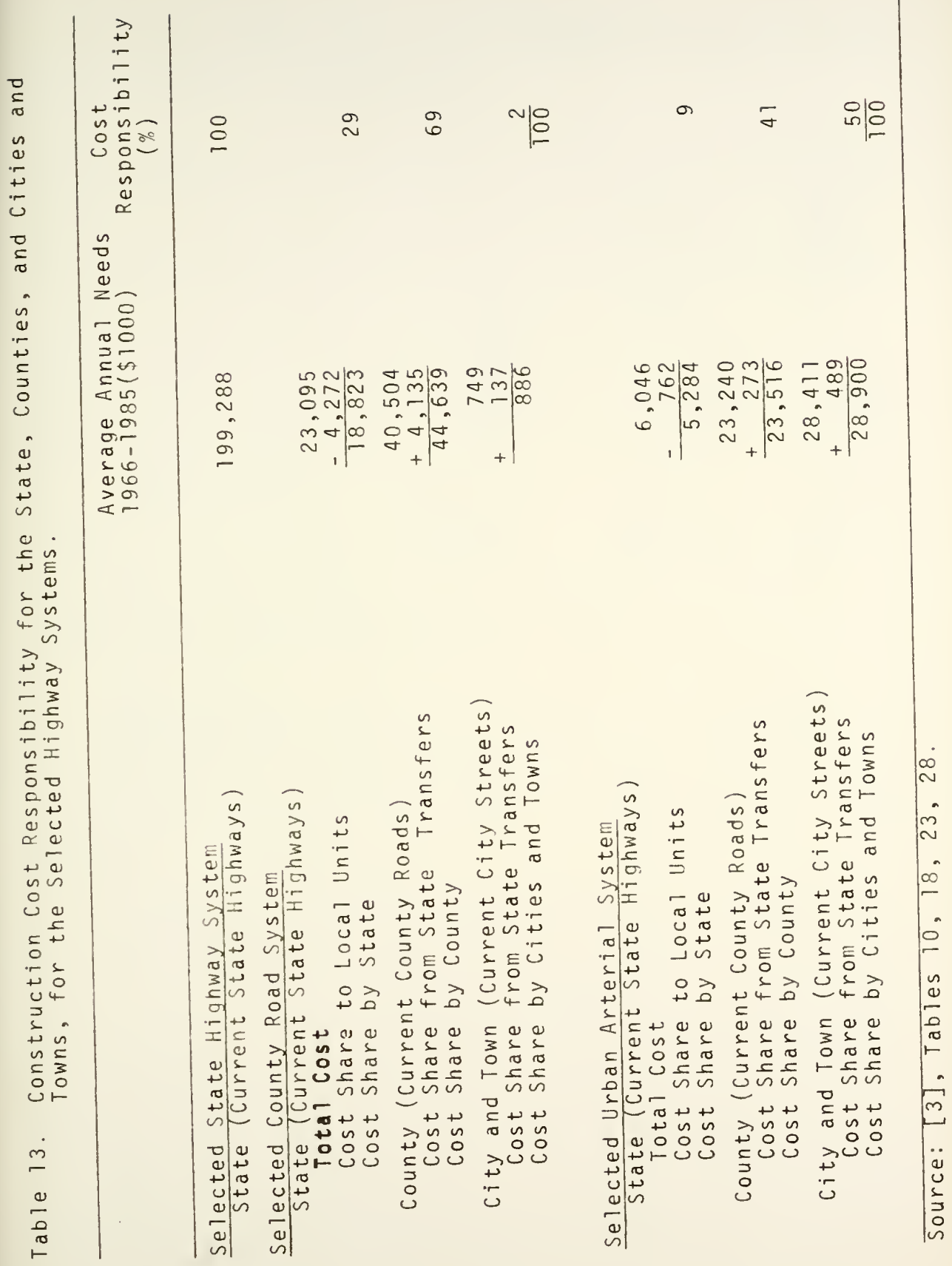


The following total annual maintenance costs resulted for each level of responsibility:

\begin{tabular}{lccc}
\hline & State & County & $\begin{array}{c}\text { Cities } \\
\& \\
\text { Towns }\end{array}$ \\
\hline State Highway System & $(\$ 1000)$ & $(\$ 1000)$ & $(\$ 1000)$ \\
County Road System & 3,616 & -- & -- \\
Urban Arterial System & 6020 & 7,504 & 129 \\
Local Access Streets & -- & 11,931 & 7,669 \\
Total & $\$ 29,247$ & $\$ 21,468$ & $\$ 10,511$ \\
\hline
\end{tabular}

Source: [3], Tables 10, 18, 23.

Administration costs were assumed to be 5 percent of the state construction and maintenance program and 3-1/2 percent of the county and city and town construction programs.

Stop Gap needs, because they are dependent on how rapidly backlog needs are eliminated were computed as a percentage of the remaining backlog needs for each year. The Needs Study suggests stop gap factors of two percent for the state highway system and one percent of the county and city and town systems for deferred construction needs less right of way costs. To correct for including right-of-way costs in the backlog needs, stop gap factors of 1.75 percent and 0.90 
percent were used instead of 2.0 percent and 1.0 percent respectively.

Replacement Needs were computed annually, based on the assumption that replacement costs will increase with increased construction activity. A replacement factor was multiplied by the annual expenditures to determine the estimated annual replacement costs. For the state system a factor of five percent was selected and for each of the county and city and town systems a higher factor of six percent was selected. The higher factor was selected for cities and towns because roads constructed at these levels are more often of a lower design standard with a shorter expected 1 ife, thus replacement costs tend to be higher.

The results of the annual needs calculations discussed in the above paragraphs are presented in Appendix $B$ in Tables Bl-B6. The column in these tables headed Program Needs is the sum of construction, maintenance and administration needs. The annual needs are also shown graphically in Figures $24-29$.

\section{Annual Revenues 1966-1985}

Having determined the needs program, it was then necessary to compare these needs with estimated future revenues to determine the financial program requirements.

Estimates of future Federal Aid, State, and local revenues were made for each year 1966-1985, based on the 


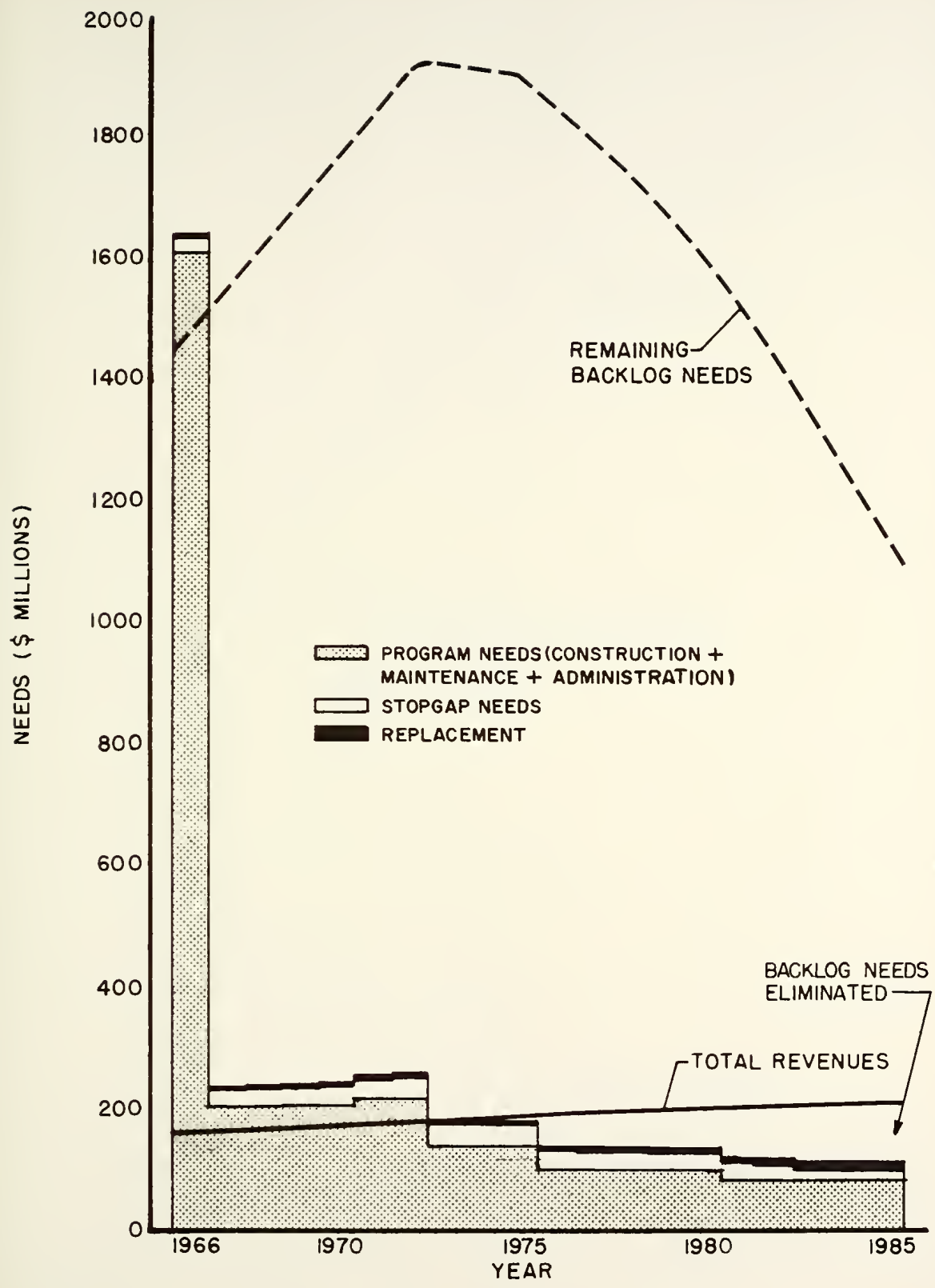

FIGURE 24. STATE HIGHWAY NEEDS, 1966-1985. (NO CHANGE IN LEVEL OF TAXATION) 


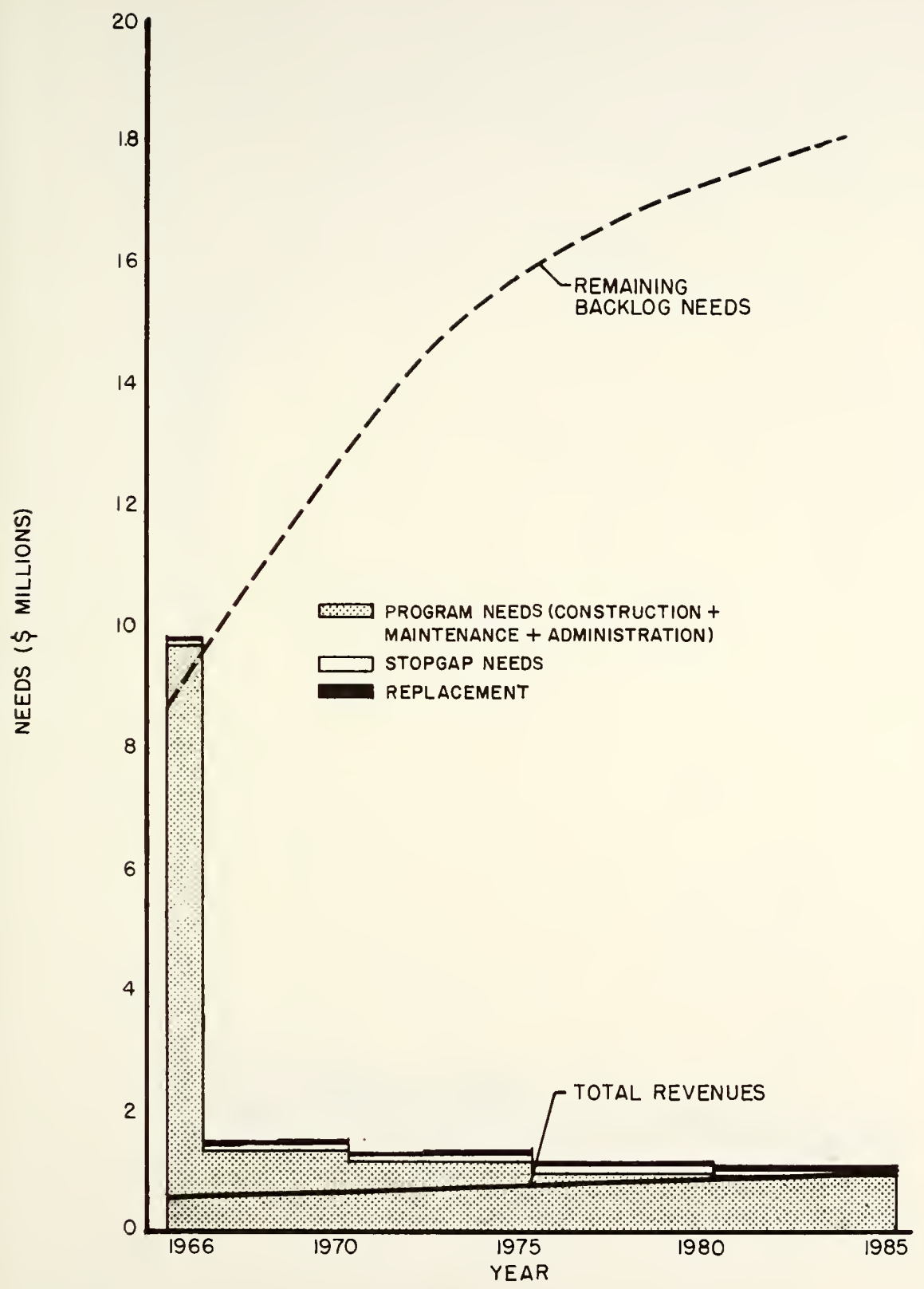

FIGURE 25. COUNTY ROAD NEEDS, 1966- 1985.

(NO CHANGE IN LEVEL OF TAXATION) 


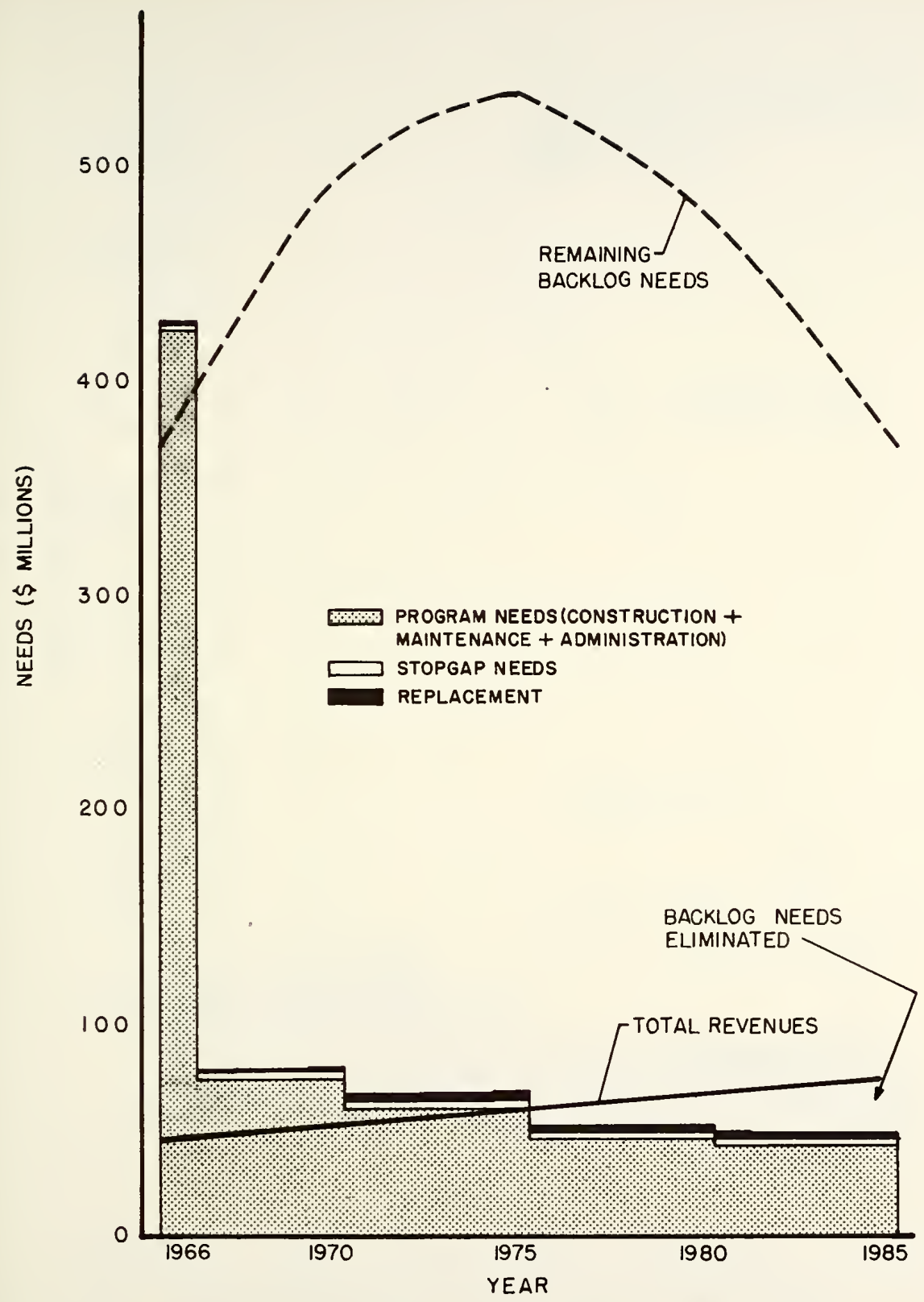

FIGURE 26. CITY AND TOWN STREET NEEDS, 1966-1985. (NO CHANGE IN LEVEL OF TAXATION) 


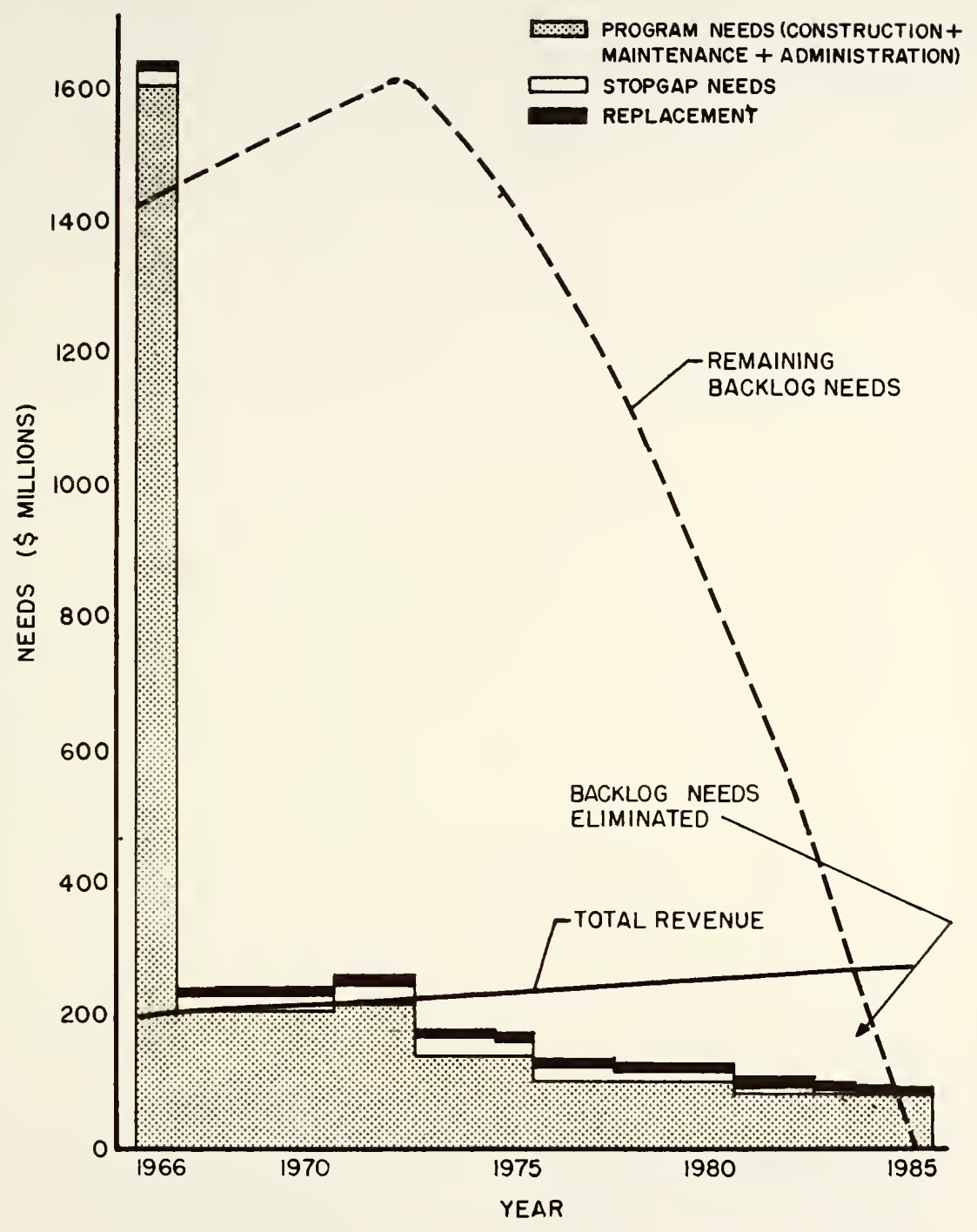

FIGURE 27. STATE HIGHWAY NEEDS, 1966-1985. (REVENUES INCREASED TO ELIMINATE BACKLOG IN TWENTY YEARS) 


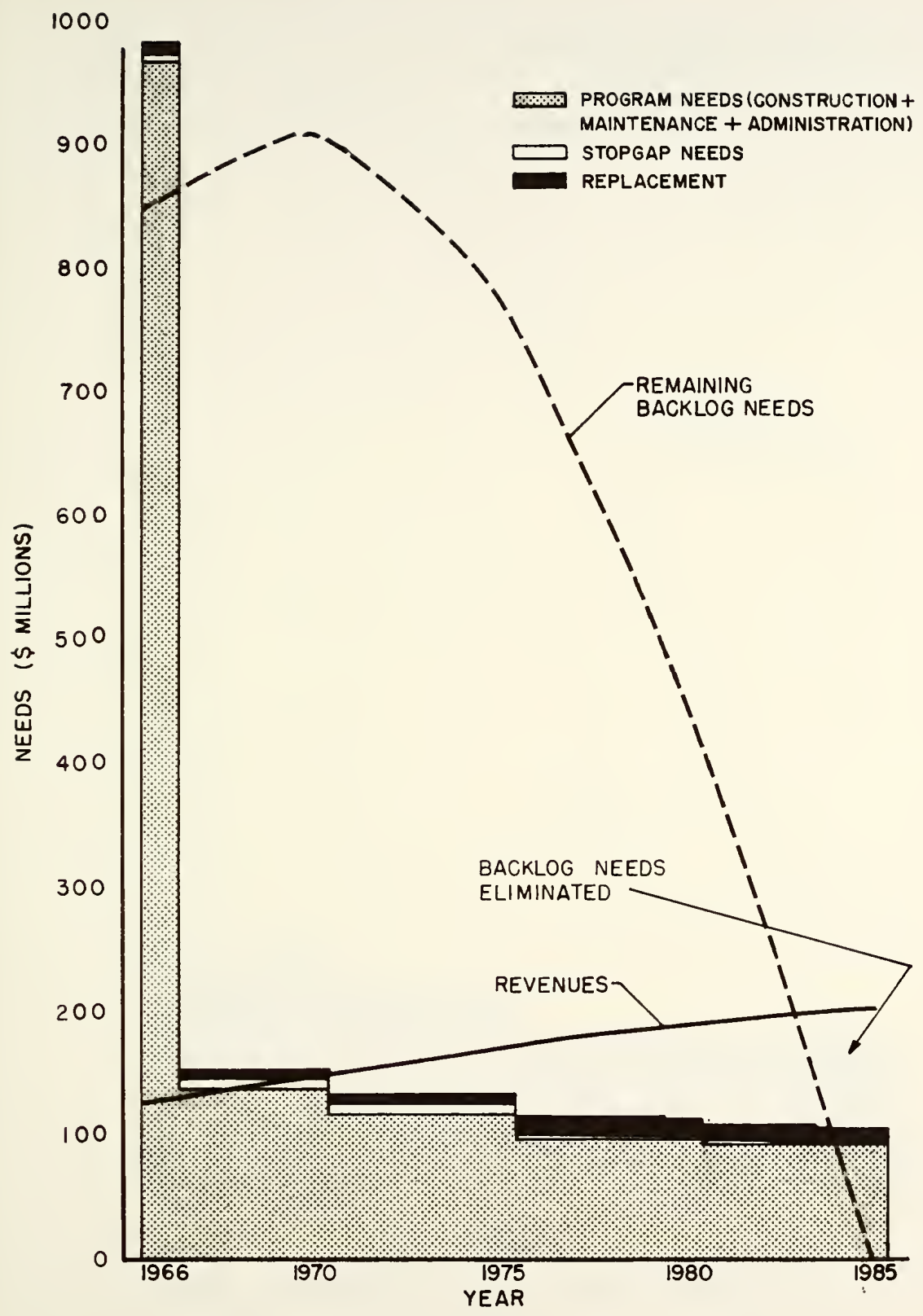

FIGURE 28. COUNTY ROAD NEEDS, 1966-1985.

(REVENUES INCREASED TO ELIMINATE BACKLOG IN TWENTY YEARS) 


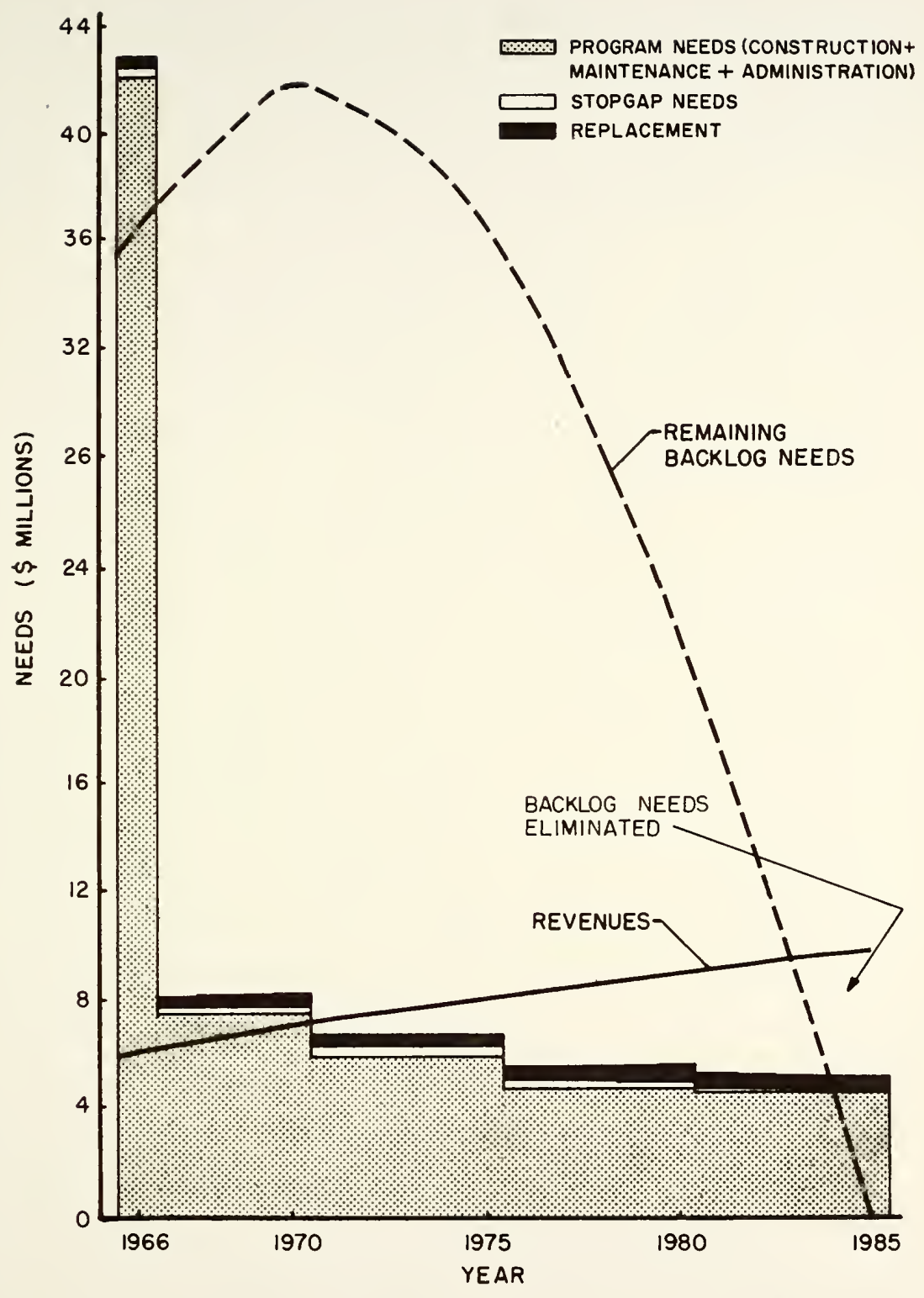

FIGURE 29. CITY AND TOWN NEEDS PROGRAM.

(REVENUES INCREASED TO ELIMINATE BACKLOG IN TWENTY YEARS) 
estimates contained in the Needs Study, and as determined for the individual revenue estimates contained in this text. The resulting annual revenues are also shown in Appendix $B$, Tables B1-B6, and graphically in Figures 24-29.

\section{No-Change Program}

A financial program which specifies no changes in levels of revenue collection requires little discussion other than to present a comparison of needs and revenues for the study period. Obviously such a program will be unable to satisfy the needs as they have been outlined; in fact, in the case of the county level of responsibility the needs backlog at the end of such a program, in other words, in 1985 , would be greater than it is now, at the beginning of the program. The comparison of needs versus revenues is presented graphically for such a program in Figures 24,25 , and 26 and in tabular form in Appendix B, Tables B1, B2, and B3.

As the normal ife of a highway pavement is about 20 years, much of the construction performed in the early stages of a 1966-1985 highway program will require reconstruction soon after 1985. As a result the program needs beyond 1985 are difficult to estimate at this date except to note that they will tend to be at least as high as the construction costs 20 years earlier. Under any conditions the results of a no-change program for Indiana would be a continuing inadequate highway system for the entire 20 year period. 


\section{0-Year Pay-As-You-Go Catch-Up Program}

A pay-as-you-go catch-up program with revenue increases sufficient to eliminate the total current backlog as well as meet continuing needs is presented in graphical form in Figures 27, 28, and 29, and in tabular form in Appendix B, Tables B4, B5, and B6. Revenue increases necessary to eliminate the needs backlog within the 20 year period are 44 percent, 113 percent, and 29 percent for the state, county, and city and town responsibilities respectively. These estimated increases were calculated as being in addition to the increases estimated for present revenue sources at current rates for the 20 year period 1966-1985.

In the early part of this chapter, four courses of action or financial programs were listed as available to Indiana. One of these was a 20 year pay-as-you-go program with an increase in revenues only partially sufficient to eliminate the needs in 20 years. Such a program, of course, could be anywhere between the two programs just discussed, a no-change program and a 20 year catch-up program. At the end of 20 years with such a program a needs backlog would still exist, its magnitude dependent on the size of the partial increase.

\section{Catch-Up Program of Less Than 20 Years}

As previously discussed it is generally considered desirable to eliminate any backlog needs within the shortest period of time, subject to the limitations of revenues and 
manpower. The debt device is one means of increasing the available revenues during the catch-up period with debt retirement being made during the period of reduced needs following the catch-up period.

With a borrowing program there are three basic variables; the length of the catch-up period, the type of borrowing device and, the number of years within which the debt is to be repaid. Catch-up periods as recommended in other states have ranged from seven to fifteen years apparently varying with the extent of the backlog and the ability of the state to generate the necessary capital and manpower. For the characteristics of the various borrowing devices reference should be made to chapter VI. For the maturity or repayment period determination, it might be desirable to repay the debt incurred for a construction program within the expected life of the facilities constructed, commonly assumed to be twenty years. Thus for a ten year catch-up program, according to this criteria, the total debt should be retired within thirty years of the initial debt incurrment.

To illustrate such a program for Indiana's 1966-1985 highway needs, a borrowing program for a ten year catch-up period with a 44 percent revenue increase has been computed for the total state highway system responsibility. An interest rate of 4.5 percent was selected as representative of the anticipated cost of capital. The 44 percent increase in revenue is that required to eliminate all backlog needs in 20 years on a pay-as-you-go program. 
Figure 30 graphically illustrates this program with the actual computations presented in Appendix $B$, Table B7. Though a determination of the feasible repayment of debt after the twenty year period is impossible without an estimate of needs, it is apparent that if the debt is repaid at a rate from year twenty to year thirty, equal to the rate paid in year twenty, that the debt will have been completely retired within the average expected life of the facilities constructed during the catch-up period. 


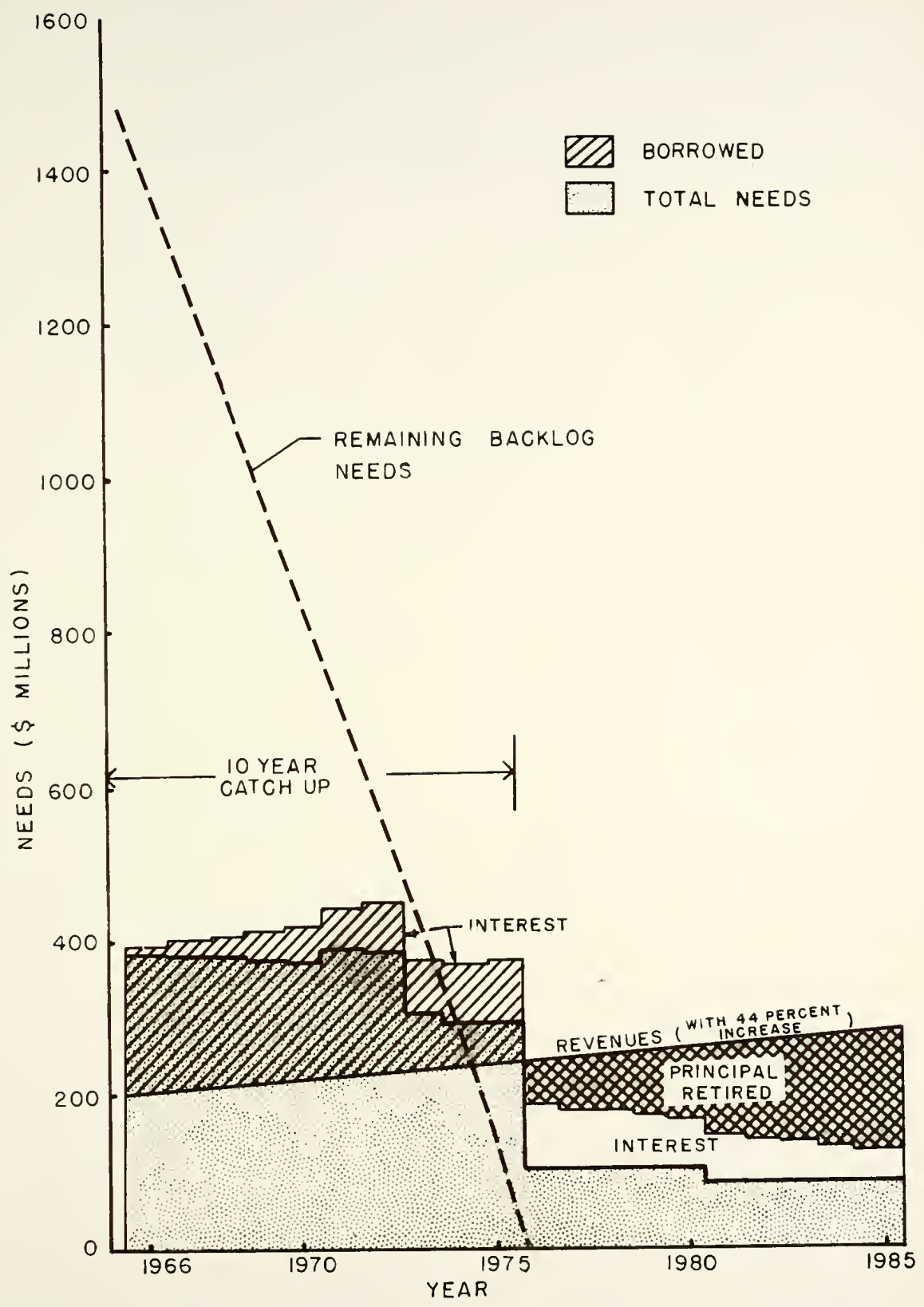

FIGURE 30. IO-YEAR CATCH-UP PROGRAM FOR THE STATE HIGHWAY SYSTEM WITH BORROWING 
CHAPTER VIII. SUMMARY AND FINDINGS

Throughout the conduct of this study four primary objectives have directed the scope of the investigation:

(1) To thoroughty examine possible sources of revenue both from the highway user and the general public and determine the feasibility of their application to highway needs financing; (2) To assess the current theoretical viewpoints on the highway financing issue especially as they pertain to questions of investment, pricing and taxation equity;

(3) to establish criteria for the distribution of state collected revenues among local units of government; and (4) To establish the yearly needs and revenues for the state, county, and city and town levels of government and determine the necessary revenue increases for elimination of the back$\log$ needs.

Although it is difficult to draw definite conclusions from a highway finance study, a summary of the findings of this study may be useful for application to the highway finance problems facing Indiana and many other states.

The policies of highway taxation have for the most part been based upon the benefit principle. That is the group or individual receiving benefits from a highway improvement should pay for this improvement in direct proportion to the 
benefits received. On the basis of this principle it is generally accepted that the major share of highway cost should be borne by the highway user, especially for through traffic facilities, with participation of the public primarily for the support of local access facilities. A determination of the user, general public cost shares has been facilitated by several cost allocation procedures, the most accepted being the earnings-credit method. These procedures generally show that the general public is paying far less than its fair share for the support of highways.

Also on the basis of the benefit principle studies agree that motor vehicles of different sizes, weights, and uses receiving varying levels of benefit from highways should pay according to these benefits. Many procedures have been employed for assessing this cost share, the most commonly accepted now being the incremental cost method. This procedure applied to Indiana highway users suggests that trucks, especially in the heavier weight categories are not providing financial support for highways in proportion to the benefits received.

Indiana (1968) is well below the 1967 national average in the level of commonly assessed user taxes: (1) The average state assessed motor fuel tax was 6.65 cents, Indiana's tax is 6 cents; (2) The average passenger car registration fee was $\$ 15.70$, Indiana's fee is $\$ 12.00$; The average truck registration is above that for Indiana for 
all weight categories, especially in the upper weight classi.fications, where Indiana presently has no class breakdown; (4) The average operator's license fee was $\$ 1.85$ for one year, Indiana's fee is $\$ 1.50$ for two years. The average chauffeur's license fee was $\$ 3.00$ for one year, Indiana's fee is $\$ 1.50$; and (5) Indiana assesses no tax differential on diesel fuel as was done in ten other states, nor does Indiana have a third structure tax as did 21 other states. There appears to be justification for a differential tax on diesel fuel on the grounds that the fuel consumption efficiency of the diesel engine gives a diesel powered vehicle for a uniform fuel tax, a tax advantage over a similar gasoline powered vehicle. The claim that such a tax differential will discourage the use of the diesel engine and of diesel fuel seems to have no validity, at least not in the ten states now imposing a diesel fuel tax differential. Indiana does have a property tax on motor vehicles as do 21 other states. The average tax in 1967 in Indiana was estimated to be $\$ 23.20$ per passenger car. The tax on trucks is greater and varies by the size of the vehicle.

of the many possible user taxes, whether presently used in Indiana or other states or not at all, the following were found to have the potential for returning a substantial amount of revenues: (1) The motor fuel tax, (2) Passenger car and truck registration fees; (3) Weight distance taxes, (4) Gross receipts taxes, and (5) Tolls. 
The following user taxes do not appear to have the potential for returning large amounts of revenues: (1) A differential tax on special fuels, (2) Drivers license fees, (3) Motor carrier fees, (4) Parking fees, and (5) Interstate fuel use taxes.

Although many public taxes such as the income tax or sales tax provide large annual revenues, many great demands are also placed upon these sources by other areas of government spending. Other taxes which might be classified as public taxes but which are highway related might be possible revenue sources for highways; (1) A state motor vehicle excise tax, (2) A tax on billboards using the highway right of way, (3) An access fee on properties having access to highways, and (4) A tax on utilities, telephone, power, gas, and water using the highway right of way. There is a question as to whether the latter tax could be assessed since many claim that the utilities have as much right on the highway right-of-way as the highway itself. Though these taxes might be levied it is unlikely that they would bring in very large amounts of revenue.

If any one or a combination of the above taxes were increased sufficiently to satisfy Indiana's highway needs, it is highly unlikely that this increase would have any influence on the demand for highways. This demand has been found to be inelastic and in the absence of any real market competition from other modes of transportation, a price increase 
required to meet Indiana's needs would not likely reduce the demand for highway travel.

The use of marginal cost pricing or congestion tolls, wherein substantial tolls are assessed to equate highway supply and demand at some desired level of service, appears to represent a viable solution for highly congested, high density urban areas, where facility expansion is extremely difficult or costly. Public opposition to such a charge on formerly "free" roads, however, presents a formidable obstacle to a congestion toll program.

Distribution of state collected highway user funds among local government levels should ideally be based upon a measure of needs. However, because of the difficulty in obtaining uniform needs information on a continuing basis the distribution of these funds is usually based upon other factors highly correlated with needs.

In other states the factors commonly used are population, motor vehicle registration, mileage, area, assessed evaluation, and fuel consumption. The determination of the factors best correlating with Indiana's highway needs was achieved by means of a stepwise 1 inear regression analysis. of the eight factors (urban population, rural population, area, county road mileage, urban road mileage, assessed evaluation, motor vehicle registration, and fuel sales) compared with needs in Indiana by counties, rural population and county road mileage were found to correlate best with 
rural needs deficits and urban mileage or population with urban needs deficits. Though the above factors were found to correlate best with needs deficits, it was found that population, assessed evaluation, and motor vehicle registration were also highly correlated with each other.

For the period 1966-1985 there are four possible courses of action available to Indiana for the improvement of its highway needs: A no-change program with no revenue increases; a revenue increase sufficient to satisfy at least a part of the highway improvement needs; a 20 year pay-asyou-go catch-up program to eliminate the backlog needs within 20 years; and a catch-up program to eliminate the backlog needs in less than 20 years. Following a course of action with no revenue increases or only partial increases will result in a continuing highway deficiency for Indiana, the extent of this deficiency depending on the level of revenue increases. A 20 year pay-as-you-go catch-up program to eliminate all backlog needs deficienciss within twenty years will require a 44 percent revenue increase at the state level of government, a 112 percent increase at the county lever, and a 29 percent increase at the city and town level. A catch-up program of less than 20 years will in all likelihood require the use of borrowing. A ten year catch-up program for state highways with the use of bonds to be retired within the highway facilities life can probably be achieved with a revenue increase of the same magnitude as the 20 year pay-as-you-go catch-up program. 
Consideration of a borrowing program for highway improvement should be made in light of the total costs and savings resulting from debt incurrment, not just the added cost of interest. First, the analysis should be made in terms of constant dollars over the borrowing period; in other words estimates of future inflationary or deflationary trends should be included. Second, the use of borrowing facilitates accelerated construction of backlog needs. This advanced construction generally results in an overall reduction in the costs for stop gap construction. Third and finally, savings in road user operating and accident costs through advanced programming usually far outweigh the added borrowing cost of debt service.

If $\$ 8.5$ million of twenty year maturity bonds had been issued at an average available interest rate of 1.75 percent in 1946, this action would have doubled the states 1946 highway construction program. The total cost of this doubling, ignoring inflation, would have been $\$ 1.6$ million, i.e., the interest on $\$ 8.5$ million over 20 years. Including the inflationary reduction in 1946 dollar value suggests that the added interest charges would have increased the construction costs only $\$ 49,000$ (1946 dollars). For a shorter term of borrowing of 10 or 15 years, rather than a net cost, a borrowing program in 1946 would have resulted in a net reduction in the total 1946 dollar cost. 
Finally, the success or failure of a highway improvement program ultimately rests with the expression of the people through their legislative representatives. It is therefore essential that every effort be made to inform the people of future highway requirements as they are expressed in statewide needs studies or other needs determinations. In this manner the public can be made thoroughly aware of the financial burden of supporting highway improvements and the consequences of failing to accept this burden. 
BI BL IOGRAPHY 


\section{B I BL IOGRAPHY}

1. 1968/Automobile Facts/Figures, Automobile Manufacturers Association, 1968.

2. Transportation and Parking for Tomorrow's Cities, Wilbur Smith and Associates, Automobile Manufacturers Association, 1966.

3. Guidelines for Progress, Indiana Highways-Roads-Streets 1966-1985. Report on Finance, Cole \& Williams Engineering Joint Venture, January 1967.

4. Guidelines for Progress, Indiana Highways-Roads-Streets 1966-1985. Report on Needs and Classification, Cole \& Williams Engineering Joint Venture, January, 7967.

5. Creating, Organizing, and Reporting Highway Needs Studies, Highway Planning Technical Report No. 1, U. S. Department of Commerce, Bureau of Public Roads, 1963.

6. Wohl, Martin, and Martin, Brian V., "Evaluation of Mutually Exclusive Design Projects," Highway Research Board Special Report 92, 1967.

7. Final Report of the Highway Cost Allocation Study. Report to 87 th Congress, House Document No. 54, 1961.

8. Lebaron, A. D., "The Theory of Highway Finance, Roots, Aims, and Accomplishments," National Tax Journal, September 1963.

9. Kafoglis, Milton Z., "Highway Policy and External Economies," National Tax Journal, March 1963.

10. Zette1, Richard M., "Objectives and Concepts of Highway User Taxation," Highway Research Board Bulletin 92, 1954 .

11. Good Roads Amendments, Text of "Constitutional Provisions Safeguarding Highway Revenues," National Highway Users Conference, Inc., Revised 1965.

12. Interstate Relationships in the Taxation of Commercial Vehicles, The Council of State Governments, February 1960 . 
13. Motor Vehicle Law Series Registration Fees and Special Taxes, National Highway Users Conference, Washington, D.C., January 1968 .

14. Highway Statistics, U. S. Department of Transportation, Federal Highway Administration, Bureau of Public Roads, volumes from 1945 to 1966.

15. Jones, Fred R., Farm Gas Engines and Tractors, McGraw Hill Publications in Agricultural Engineering, 4 th Edition, 1963 .

16. White, Charles P., Financing an Expanded Highway Program in Tennessee, Bureau of Business and Economic Research, College of Business Administration, The University of Tennessee, 1957 .

17. Kent, Malcolm F., "Fuel and Time Consumption Rates for Truck and Freight Service," Public Roads, April 1960.

18. Oglesby, C. H. and Hewes, L. T., Highway Engineering, John Wiley \& Sons, Inc., 1963.

19. Brown, S P., "The Future of Toll Roads," Traffjc Quarterly, October 1961.

20. Owen, w. and Dearing, J., Toll Roads, The Brooking Institute, 1951 .

21. McCallum, William R., "Highway Bond Financing--A Current Analysis," Highway Research Board Record 20, 1963.

22. Claffey, Paul J., "Characteristics of Passenger Car Travel on Toll Roads and Comparable Free Roads," Highway Research Board Bulletin 306, 1961.

23. Fitch, L. C., "Prices and Costs in Urban Transportation Financing," The Dynamics of Urban Transportation, Automobile Manufacturers Association, Inc., 1962.

24. Zettel, Richard M. and Carl1, Richard R., "The Basic Theory of Efficiency Tolls," Highway Research Record No. $-47,1964$.

25. Fitch, L. C., Urban Transportation and Public Policy, Chandler Publishing Co., 1964.

26. St. Clair, G.P., "Congestion Tolls--An Engineer's Viewpoint," Highway Research Record 47, 1964.

27. Studies in Indiana Highway Finance, Indiana Commission of State Tax and Finance Policy, Edited by C. F. Bonser, January 1965 . 
28. "Problems Arising Out of Third Structure Taxes," Financing Highways. -Tax Institute, 1957.

29. Letter from A. A. Flatt, Department of Motor Transportation, Commonwealth of Kentucky, May 13, 1968.

30. Eckstein, Otto, Public Finance, Foundation of Modern Economic Series, Prentice-Ha17, Inc., 1964.

31. Tybout, Richard A., "The Problem of Non-User Revenues," Highway Research Record No. 20. 1963.

32. Branham, A. K., Covault, D. 0. and Michael, H. L., "Progress Report on State Highway Needs in Indiana," Proceedings of the 42 nd Road School, Purdue University, 1956.

33. An Analysis of Utility Use of Highway Right-of-Way in Utah, Bureau of Economic and Business Research, College of Business, University of Utah, 1960.

34. Lemly, James H., Non-vehicular Benefits from Utility Use of Streets and Highways, Bureau of Business and Economic Research, Georgia State College of Business Administration, 1960 .

35. Sandage, C. H. and Fryburger, Vernon, Advertising Theory and Practice, Richard D. Irwin, Inc., 5 th Edition, 1958 .

36. "Outdoor Advertising Along Highways--A Legal Analysis," Highway Research Board Special Report 41, 1958.

37. Inventory of Junkyards and Billboards in Indiana, Indiana State Highway Commission, 1967.

38. Handbook of Facts and Figures on Indiana County Roads, Highway Extension and Research Project for Indiana Counties, Purdue University Engineering Experiment Station, Volumes 1960 to 1967.

39. Grossack, Irvin M., "A Forecast of the Demand for Highway Services in Indiana, 1965-1985," Studies in Indiana Highway Finance, Indiana Commission of State Tax and Financing Policy, January 1965.

40. Annual Report 1966-1967, Indiana Department of Revenue, January 1968.

41. Buchanan, James M., The Public Finances, Richard D. Irwin, Inc., 1960. 
42. The State of the Art of Traffic Safety, Arthur D. Little, Inc., Automobile Manufacturers Association, Inc., 1966.

43. Burch, Philip H., Highway Revenue and Expenditure Policy in the United States, Rutgers University Press, 1961.

44. Draper, N. R. and Smith, H., Applied Regression Analysis, John Wiley \& Sons, Inc., 1966.

45. Financing Kentucky's Roads and Streets, Bureau of Business Research, University of Kentucky, 1956.

46. "Basic Theory of State Highway Finance," Financing Highways, Princeton University, Symposium Proceedings, November 8-9, 1956 .

47. Acceleration of Road Improvements Through Bond Issues, National Highway Users Conference, Inc., November, 1955.

48. Highway Bond Financing--An Analys is 1950-1962, U. S. Department of Commerce, Bureau of Public Roads, U. S. Government Printing Office, September 1963.

49. Lee, Robert R. and Grant, E. L., "Inflation and Highway Economy Studies," Engineering Economy, Highway Research Record 100,1965 .

\section{General References}

1. Annual Report of the Auditor of the State of the State of Indiana, June 30, 7966 .

2. 1966-1967 Annual Report of the Indiana Department of State Revenue, Revenue Research Division, 1968.

3. Baker, Robert F. and Tybout, Richard A., Data Analysis and Conclusions for the Ohio Highway Needs Study--Fina? Report, Ohio State University, 1961 .

4. Brownlee, 0. H., "Pricing and Financing Highway Services," Highway Research Bulletin 222, 1959.

5. Burns' Indiana Statutes, Bobbs-Merrill Company, 1967.

6. Cline, Denzel C., Taylor, Milton C. and Paoke, James A., Michigan Highway Fiscal Study, Michigan State University, 1961 .

7. Campbe 11, Gordon D., An Analys is of Highway Finance and Road User Imports in Canada, Purdue University, 1956. (Unpublished Ph.D. Thesis). 
8. Criteria for Highway Benefit Analysis, Volume I, Highway Economic Series, University of Washington, 1961.

9. Hal1, William L., Financing Modern Highways for Montana, Montana Fact Finding Committee on Highways, Streets and Bridges, 1956.

10. Intermediate Report-Highway Finance Study, Louisville, Metropolitan Comprehensive Transportation and Development Program, 1968.

11. Lansing, John B., Transportation and Economic Policy, The Free Press, New York, 1966.

12. Melton, L. J., "A Rational Approach to Highway Finance," Land Economics, February 1966.

13. Meyer, J.R., Peck, M. S., Stenason, J. and Zwick, C., Competition in the Transportation Industries, Harvard University Press, 1960.

14. Mohring, H. and Hurwitz, M., Highway Benefits an Analytical Framework, Transportation Center, Northwestern University, 1962 .

15. 1968 National Highway Needs Report, 90 th Congress, 2nd Session, U. S. Government Printing office, 1968.

16. Road-Use and Property Taxes on Selected Motor Vehicles, 1968, U. S. Department of Transportation, Federal Highway Administration, Bureau of Public Roads.

17. St. Clair, G. P. and Todd, T. R., "Financial Planning for an Expanded Highway Program," Highway Research Board Proceedings, Vol. 35, 1956.

18. Taxes and Traffic, Canadian Tax Foundation, 1955. 
APPENDIX A: M.V.H.A. FUND DISTRIBUTION TO LOCAL GOVERNMENT LEVELS, ACCORDING TO PROPOSED DISTRIBUTION FORMULAS 
APPENDIX A: M.V.H.A. FUND DISTRIBUTION TO LOCAL GOVERNMENT LEVELS, ACCORDING TO PROPOSED DISTRIBUTION FORMULAS

\section{Description of Tables}

In the following tables, Tables Al to A9, fund distribution to local government levels are tabulated by counties for each of the proposed distribution formulas of Table 10. The distributions are compared with the estimated average annual needs deficits for each county.

For Total Fund Distribution to County Tables A7, A8, and $A 9$, the following should be noted:

Table A7, Alternative 1 , is the result for each county, both urban and rural, of Alternative 1 to urban areas and Alternative 1 to rural areas.

Table A8, Alternative 2 , is the result for each county, both urban and rural, of Alternative 2 to urban areas and Alternative 2 to rural areas.

Table A9, Alternative 3 is the result for each county, both urban and rural, of Alternative 3 to urban areas and Alternative 3 to rural areas. 
TARLE AI. FUNC CISTRIBUTICN TO URBAN AREAS

\section{COUNTY}

1 ADAAS

2 ALLEN

3 EAR THCLCNEW

4 EENTCA

5 ELACKFCRC

6 BCC ME

7 ERCHA

8 CARFCLL

9 CAS :

10 CLAFK

11 CLAY

12 CLIATCA

13 CRALFCRC

14 CAV IESS

15 CEAFECRA

16 CEC ITUR

17 CEK ILB

18 CEL IWARE

19 CUECIS

2C ELKH ART

¿1 FAYETTE

22 FLCYC

23 FCURTAIA

24 FRARKLIA

25 FULTCN

26 GIE SCN

27 GRANT

28 GREENF

29 HAF ILTCA

?O PAA CCCK

31 HARFISCA

32 HEALRICKS

23 HEAFY

24 HCh $/ R C$

35 HUATINGTCA

36 JACKSCA

37 JASFER

38 JAY

39 JEFFERSCA

4C JENRINES

41 JOHASCN

42 KNC)

43 KOS CIUSKC

44 LAGFANGE

45 LAKE

46 LAFCRTE
ALTERNAT IVE 1

NEECS DEFICIT FORMLLA CIST DIST/ CCLLARS PERCENT PERCENT DCLLARS DEFICIT

(\%)

\begin{tabular}{|c|c|c|c|c|}
\hline $\begin{array}{l}2 \\
2 \\
1 \\
2 \\
5 \\
6 \\
3 \\
2 \\
1 \\
3 \\
2\end{array}$ & $\begin{array}{l}C .48 \\
4.65 \\
C .88 \\
C .23 \\
C .52 \\
C .57 \\
C .01 \\
C .15 \\
C .88 \\
1.46 \\
C .73 \\
C .55 \\
C .15 \\
C .74 \\
C .52 \\
C .32 \\
C .82 \\
C .83 \\
C .39 \\
2.28 \\
C .6 C \\
1.03 \\
C .61 \\
C .09 \\
C .13 \\
C .55 \\
2.25 \\
C .78 \\
C .57 \\
C .3 G \\
C .32 \\
C .52 \\
1 . C 5 \\
1.26 \\
C .66 \\
C .55 \\
C .25 \\
C .78 \\
C .44 \\
C . C 2 \\
C .94 \\
C .92 \\
C .79 \\
C .08 \\
11.63 \\
2.07\end{array}$ & $\begin{array}{l}\text { C.42 } \\
5.62 \\
C .75 \\
0.21 \\
C .34 \\
C .5 C \\
C . C 2 \\
C .17 \\
C .82 \\
1.22 \\
C .4 C \\
C .64 \\
C . C 8 \\
C .47 \\
C .4 t \\
C .25 \\
C .53 \\
2.51 \\
C .45 \\
2 . C 6 \\
C .6 C \\
1.31 \\
C .36 \\
C .15 \\
C .23 \\
C .57 \\
1.75 \\
C .45 \\
C .54 \\
C .45 \\
C .15 \\
C .57 \\
1 . C C \\
1.63 \\
C .68 \\
C .54 \\
C .22 \\
C .42 \\
C .38 \\
C .15 \\
C .85 \\
C .87 \\
C .56 \\
C .11 \\
14.81 \\
2.18\end{array}$ & $\begin{array}{r}214913 . \\
2877973 . \\
4 C 5432 . \\
1 C 7156 . \\
1752 C 6 . \\
255324 . \\
8446 . \\
86333 . \\
418788 . \\
624157 . \\
264459 . \\
325554 . \\
42145 . \\
241883 . \\
237265 . \\
14846 C . \\
273247 . \\
12836 C 5 . \\
225128 . \\
1 C 5412 C . \\
3 C 5824 . \\
667932 . \\
181764 . \\
774 C 6 . \\
115 C 53 . \\
254 C 87 . \\
514 C 72 . \\
227788 . \\
2742 C 8 . \\
23 C 243 . \\
77818 . \\
251358 . \\
511112 . \\
8217 C 5 . \\
356034 . \\
273813 . \\
1112851 . \\
22 C 475 . \\
155789 . \\
77663 . \\
454667 . \\
443783 . \\
287633 . \\
56393 . \\
7577688 . \\
1113553 .\end{array}$ & $\begin{array}{r}86.92 \\
121.12 \\
89.73 \\
92.15 \\
65.79 \\
86.85 \\
121.81 \\
115.32 \\
93.26 \\
83.32 \\
54.98 \\
117.25 \\
56.47 \\
64.00 \\
89.96 \\
96.46 \\
65.38 \\
88.75 \\
114.18 \\
96.21 \\
16 C .32 \\
127.00 \\
58.59 \\
167.62 \\
179.95 \\
164.80 \\
79.34 \\
57.17 \\
93.99 \\
114.02 \\
47.47 \\
11 C .50 \\
95.27 \\
129.37 \\
163.29 \\
97.13 \\
96.83 \\
55.15 \\
87.45 \\
616.38 \\
94.15 \\
94.19 \\
7 C .96 \\
135.98 \\
127.37 \\
71.01\end{array}$ \\
\hline
\end{tabular}


TARLE AI. FUNC CISTRIEUTICN TO LRBAN AREAS

CCLNTY

47 LAHFENCE

48 MAC ISCA

49 MARICA

50 MARSHALL

51 MARIIA

52 MIANI

53 NOAFCE

54 MCA TGCNEFY

55 NCREAA

-6 $\triangle E$ S TCA

57 ACEIE

$58 \mathrm{CHIC}$

59 CRAIGE

ED CWEP

EI FARFE

$\in 2$ FER F

E 3 FIKI

E4 FCFTER

65 FCSIY

66 FULISKI

t 7 FUT IAN

$E$ FAN[CLPF

$t 9$ RIFIEY

70 RUS

II ST . CSEFF

12 SCCIT

13 SHE IEY

74 SPEACER

75 STAFKE

76 STELEFA

77 SULIIVAA

78 SWITZFRLAAL.

T9 TIFIECANCE

EO TIFTCA

\& I LAICA

\& 2 VAAIEREUPEH

\& 3 VER ILLICA

C4 VIEC

E 5 hAE ISH

\&6 hARFEA

E 7 hAPFICK

$\varepsilon 8$ hAS IAGTCA

\& 9 hAYAE

CO hELIS

C I WHITE

S 2 HHITLEY
ALTERNATIVE 1

AEECS CFFICIT FORMLLA CIST P DIST/ $(\%)$
CCLLARS PERCENT PERCENT DCLLARS DEFICIT

\begin{tabular}{|c|c|c|c|c|}
\hline 659 & $\begin{array}{l}C .53 \\
4.35 \\
15.45 \\
C .55 \\
C .13 \\
C .47 \\
C .71 \\
C .6 C \\
C .55 \\
C .17 \\
C .5 C \\
C . C 2 \\
C .55 \\
C . C C \\
C .2 C \\
C .3 C \\
C .2 C \\
3.9 C \\
C .34 \\
C .17 \\
C .2 G \\
C .45 \\
C .21 \\
C .2 C \\
C .31 \\
C .17 \\
C .4 C \\
C .26 \\
C .26 \\
C .3 C \\
C .85 \\
C . C 2 \\
1.15 \\
C .22 \\
C . C 7 \\
2.75 \\
C .64 \\
3.35 \\
C .91 \\
C .11 \\
C .26 \\
C .23 \\
1.2 C \\
C .23 \\
C .29 \\
C .13\end{array}$ & 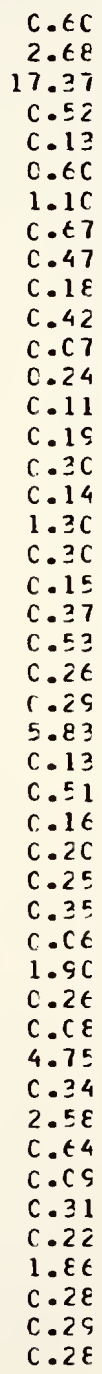 & 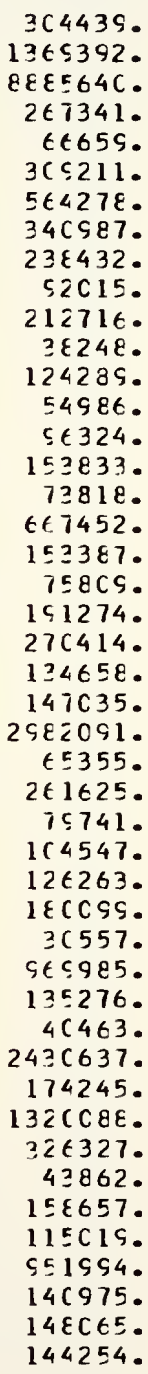 & $\begin{array}{r}111.74 \\
61.55 \\
112.46 \\
94.62 \\
95.33 \\
129.71 \\
154.49 \\
55.97 \\
84.43 \\
105.16 \\
82.69 \\
484.46 \\
43.93 \\
115.00 \\
71.41 \\
82.69 \\
7 C .65 \\
32.73 \\
88.59 \\
88.90 \\
125.69 \\
116.46 \\
125.10 \\
58.70 \\
169.76 \\
75.58 \\
128.83 \\
6 C .95 \\
77.49 \\
64.30 \\
41.56 \\
264.38 \\
165.07 \\
121.50 \\
117.05 \\
172.69 \\
53.47 \\
76.10 \\
7 C .18 \\
77.56 \\
119.96 \\
96.14 \\
155.20 \\
119.05 \\
1 C 0.76 \\
218.88\end{array}$ \\
\hline
\end{tabular}


TARLE A2. FUNC CISTRIBUTION TO URBAN AREAS

COUATY

1 ADAPS

2 ALLEA

3 EAR THCLCNEW

4 EEATCA

5 ELACKFCRL

6 ECCAE

7 ERC $B A$

8 CARFCLL

9 CASS

10 CLAFK

11 CLA)

12 CLINTCA

13 CRALFCRC

14 CAVIESS

15 CEAFECRA

16 CEC ITUR

17 CEK /L 8

18 CEL IWARE

19 CUECIS

20 ELKFART

21 FAYFTTE

22 FLCIC

23 FCUNTAIA

24 FRAMKLIA

25 FULTCA

26 GIESCA

27 GRANT

28 EREENE

29 HAM ILTCA

30 HAACCCK

31 HAFFISCA

32 HEALRICKS

33 HEAFY

34 HOW LRC

35 HUN IINETCA

36 JACKSCN

27 JAS FER

38 JAY

39 JEFFERSCA

40 JEAAIAGS

41 JOHASCN

42 KNC)

43 KOSCIUSKC

44 LAGFANGE

45 LAKE

46 LAFIRTE
ALTERNATIVE 2

NEECS DEFICIT FORMLLA DIST DIST/ CCLLARS PERCENT PERCENT DOLLARS DEFICIT

\begin{tabular}{|c|c|c|c|c|}
\hline 247252 . & $\begin{array}{l}C .48 \\
4.65 \\
C .88 \\
C .23 \\
C .52 \\
C .57 \\
C . C 1 \\
C .15 \\
C .88 \\
1.46 \\
C .73 \\
C .55 \\
C .15 \\
C .74 \\
C .52 \\
C .37 \\
C .82 \\
2.83 \\
C .39 \\
C .28 \\
C .6 C \\
1 . C 3 \\
C . C 1 \\
C . C S \\
C .13 \\
C .55 \\
Z .25 \\
C .78 \\
C .57 \\
C .39 \\
C .32 \\
C .52 \\
1 . C 5 \\
1.26 \\
C .6 C \\
C .55 \\
C .25 \\
C .78 \\
C .44 \\
C . C 2 \\
C .94 \\
C .92 \\
C .79 \\
C . C 8 \\
11.63 \\
3.07\end{array}$ & 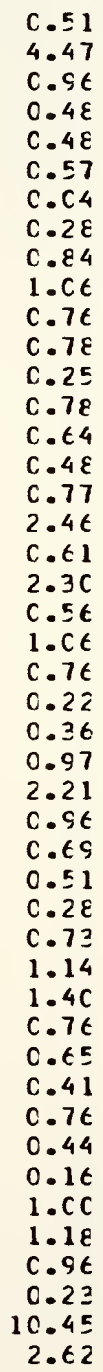 & 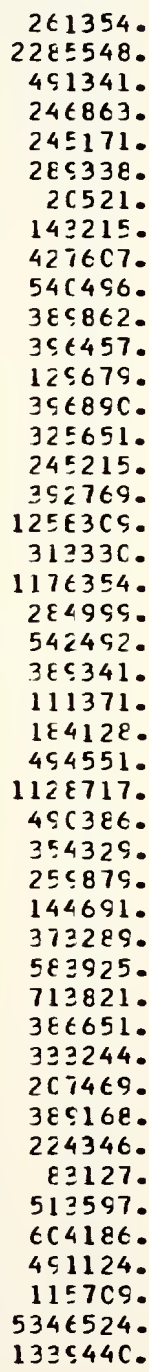 & $\begin{array}{r}1 C 5.70 \\
96.19 \\
1 C 8.74 \\
212.29 \\
92.06 \\
98.41 \\
295.95 \\
191.30 \\
95.23 \\
72.15 \\
1 C 4.84 \\
141.05 \\
173.76 \\
1 C 5.02 \\
123.47 \\
145.41 \\
53.98 \\
87.00 \\
156.15 \\
1 C 6.67 \\
93.55 \\
1 C 3.14 \\
125.50 \\
241.17 \\
278.32 \\
176.24 \\
97.98 \\
123.08 \\
121.45 \\
128.69 \\
88.27 \\
141.57 \\
1 C 8.85 \\
111.03 \\
114.10 \\
118.21 \\
165.51 \\
97.34 \\
16 C .21 \\
659.73 \\
1 C 6.35 \\
128.23 \\
121.16 \\
279.00 \\
89.87 \\
85.41\end{array}$ \\
\hline
\end{tabular}


TAPLE A2. FUNC CISTRIEUTICN TO LRBAN AREAS

$\operatorname{COLATY}$

47 LALFENCE

48 MAC ISCA

49 AAF ICA

50 PAR HALL

E. 1 MARTIA

52 MIARI

53 MCAFCE

54 MCNTGCNEFY

55 MCREAA

56 AEHTCN

E7 ACE IE

58 CHIC

59 CRANGE

EC CWE

$\in 1$ FARFE

C2 FERFY

E FIKE

64 FOR IER

E5 FCSEY

6 FUL ISKI

67 FUT IAN

$t 8$ PANCCLPF

69 RIFIEY

70 RUSt

71 ST. . CSEFH

72 SCE IT

73 SHEIEY

74 SPEACER

75 STAFKF

76 STELEFN

77 SULIIVAA

78 SWITZERLANC

79 IIFFECANCE

EC TIFICA

\& 1 LNICA

F 2 VAAIERELIFEH

E 3 VERPILLICA

E4 VIEC

E 5 hAE \&SH

$\varepsilon 6$ hARFEA

E 7 WARFICK

$\varepsilon 8$ hAS INGTCA

E9 hAYAE

CC REL IS

C 1 WHIIE

C 2 HHI ILEY

\begin{abstract}
ALTERNATIVE 2
NEECS DEFICIT FORMLLA CIST DISTI CCLLARS PERCENT PERCENT CCLLARS DEFICIT

$(\%)$
\end{abstract}

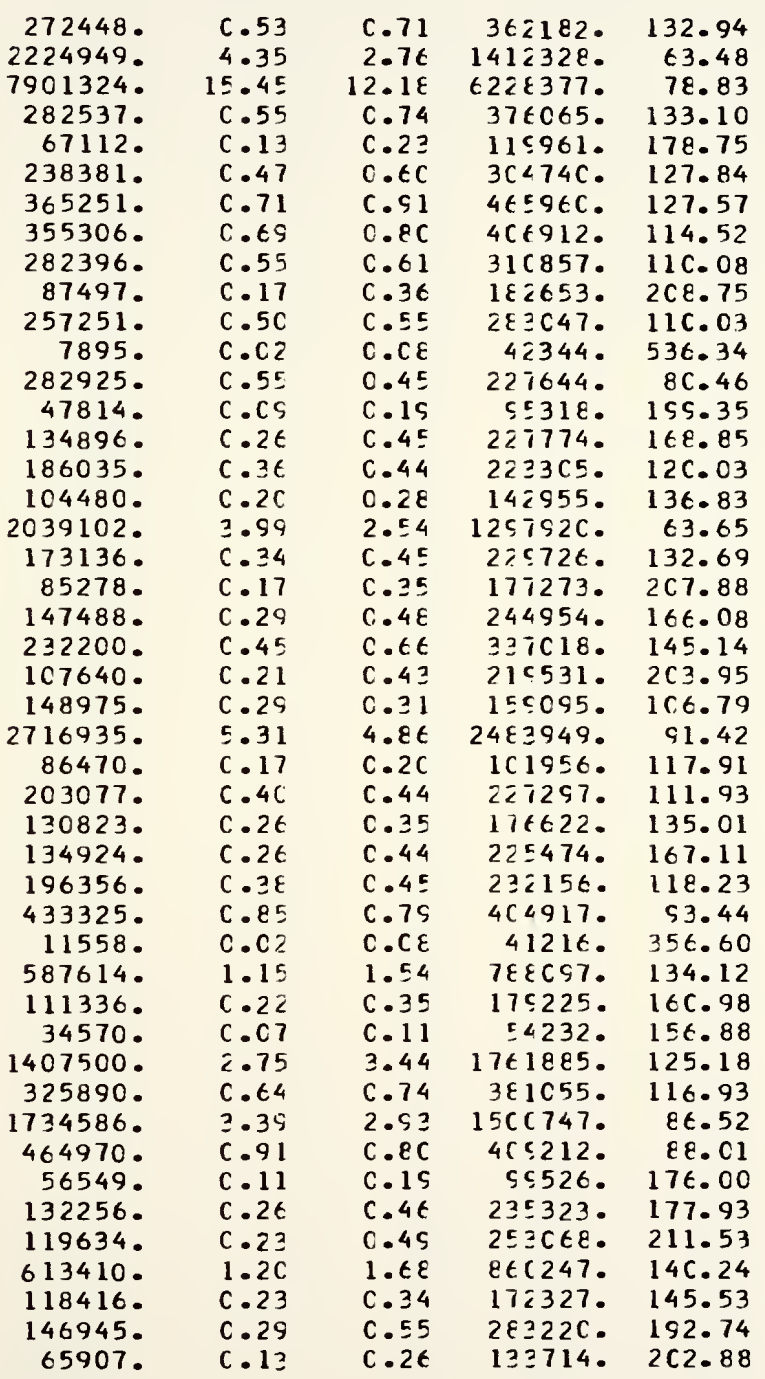


TAELE A3. FUAC CISTRIBUT ICN TD LRBAN AREAS

\section{COUPTY}

$1 \triangle D A B S$

2 ALLEN

3 EARTHCLCHEW

4 BEATCA

5 ELACKFCRL

6 ECCPE

7 ERCVA

8 CARFCLL

9 CAS

10 CLAFK

11 CLAY

12 Ci INTCA

13 CRALFCRC

14 CAV IESS

15 CEAFECRA

16 CEC ITUR

17 CEK ILE

18 CEL /WARE

19 CUECIS

$\angle O$ ELKIART

21 FAYFTTE

22 FLCID

23 FCLATAIA

24 FRAAKLIA

25 FULTCA

26 GI ESCA

27 GRANT

28 GREEAE

29 HAF ILTCA

20 HAACCCK

21 HARFISCA

32 HEA [RICKS

23 HEAFY

$34 \mathrm{HOW} / \mathrm{RC}$

25 HUA TIAGTCA

26 JACKSCA

37 JASFER

38 JAY

39 JEFFERSCA

40 JEANINGS

41 JOHASCA

42 KNC

43 KOS (IUSKC

44 LACIANGE

45 LAKE

46 LAFCRTE
ALTERNATIVE 3

AEECS DEFICIT FORMULA CIST PIST/
CCLLARS PERCENT PERCENT DCLLARS DEFICIT

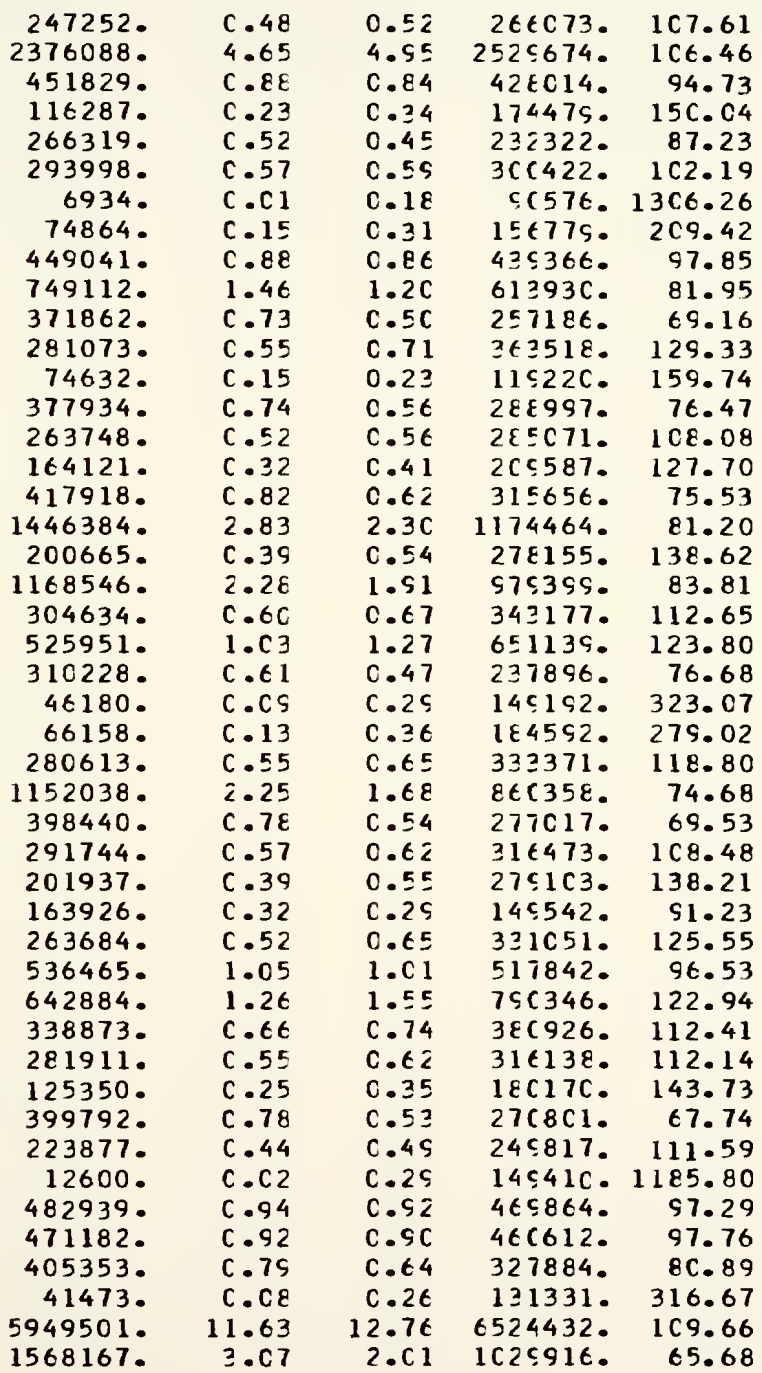


COLNTY

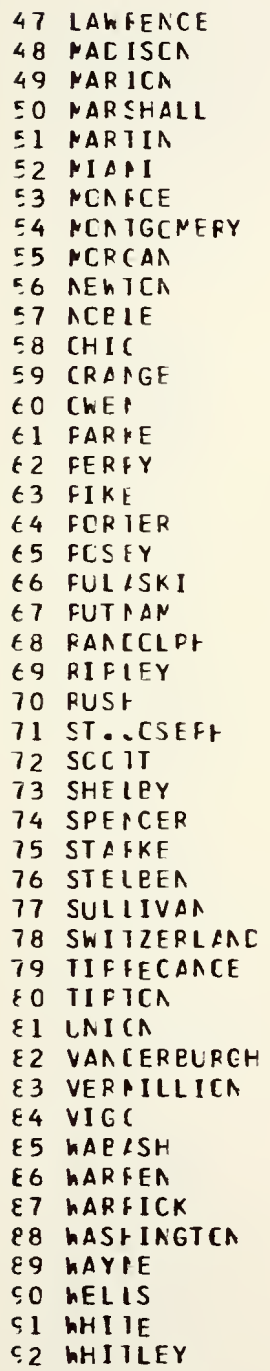

ALTERNAT IVE 3

NEECS DEFICIT FORMLLA DIST
CCLLARS FERCENT PERCENT DCLLARS DEFICIT

\begin{tabular}{|c|c|c|c|c|}
\hline 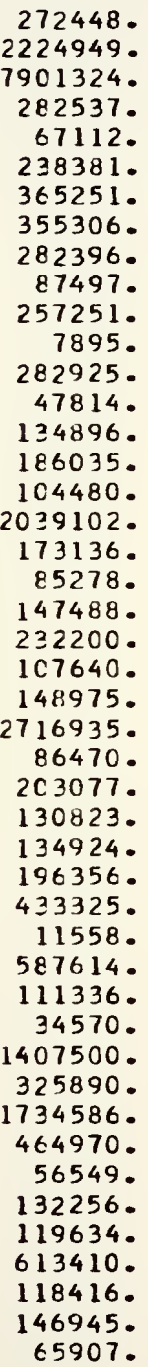 & $\begin{array}{r}C .53 \\
4.35 \\
15.45 \\
C .55 \\
C .13 \\
C .47 \\
C .71 \\
C .69 \\
C .55 \\
C .17 \\
C .5 C \\
C . C 2 \\
C .55 \\
C . C S \\
C .2 t \\
C .36 \\
C .2 C \\
3.59 \\
C .34 \\
C .17 \\
C .2 S \\
C .45 \\
C .21 \\
C .29 \\
C .31 \\
C .17 \\
C .4 C \\
C .2 C \\
C .2 t \\
C .38 \\
C .85 \\
C .02 \\
1.15 \\
C .22 \\
C .07 \\
2.75 \\
C .64 \\
2.3 S \\
C .91 \\
C .11 \\
C .26 \\
C .23 \\
1.2 C \\
C .23 \\
C .2 S \\
C .13\end{array}$ & $\begin{array}{l}C .67 \\
2.44 \\
14.53 \\
C .61 \\
C .27 \\
C .68 \\
1.1 C \\
0.73 \\
C .56 \\
C .32 \\
C .52 \\
C .23 \\
C .37 \\
C .25 \\
C .32 \\
C .42 \\
C .25 \\
1.27 \\
C .42 \\
C .25 \\
C .48 \\
C .61 \\
C .35 \\
C .41 \\
5.12 \\
C .27 \\
C .6 C \\
C .3 C \\
C .34 \\
C .27 \\
C .4 t \\
C .21 \\
1.77 \\
C .35 \\
C .23 \\
4.2 C \\
C .45 \\
2.3 t \\
C .71 \\
C .24 \\
C .42 \\
C .35 \\
1.75 \\
C .4 C \\
C .41 \\
C .4 C\end{array}$ & 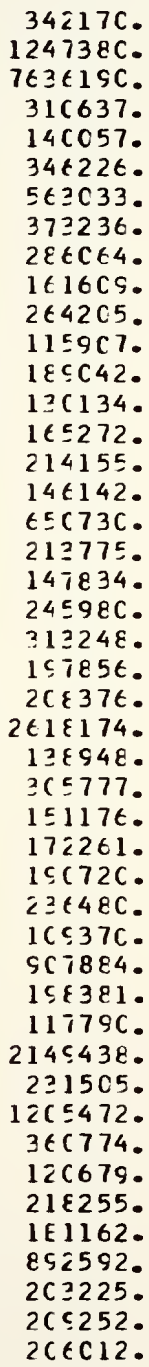 & $\begin{array}{r}125.5 \\
56.0 \\
96.6 \\
1 C 9.9 \\
2 C 8.6 \\
145.2 \\
154.1 \\
1 C 5.0 \\
1 C 1.3 \\
184.7 \\
162.7 \\
14 \in 8.1 \\
\epsilon 6.8 \\
272.1 \\
122.5 \\
115.1 \\
139.8\end{array}$ \\
\hline
\end{tabular}




\section{COUPYY}

1 ADAPS

$2 \triangle L L E A$

3 EARTHCLCHEW

4 EEATCN

5 ELACKFCRC

6 ECCIE

7 ERCHA

8 CARFCLL

9 CASS

10 CLAFK

11 CLAY

12 CLINTCA

13 CRA IFCRE

14 CAV IESS

15 CEAFECRA

16 CEC ITUR

17 CEK ILE

18 CEL LWARE

19 CUECIS

¿C ELK+ART

¿I FAYETTE

22 FLCIC

23 FOUNTAIA

24 FRANKLIA

25 FULTCA

26 GI $\leq C A$

27 GRANT

28 GREENE

29 HAM ILTCA

30 HAA CCCK

31 HAR I ISCA

32 HEAIRICKS

33 HENFY

$34 \mathrm{HCh} / \mathrm{RC}$

35 HUA TINGTCA

36 JACKSCA

27 JASIER

28 JAY

39 JEFFERSCA

40 JEN INGS

41 JOHISCN

42 KNCX

43 KCS IIUSKC

44 LAGFANGE

45 LAKE

46 LAFCRTE
ALTERNATIVE 1

NEECS DEFICIT FORMLLA DIST DISTI $(\%)$
CCLLARS PERCENT PERCENT DCLLARS DEFICIT

\begin{tabular}{|c|c|c|c|c|}
\hline 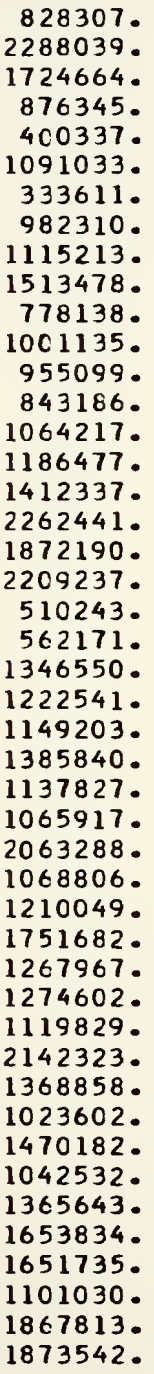 & $\begin{array}{l}C .7 C \\
1.94 \\
1.4 \epsilon \\
C .74 \\
C .34 \\
C .93 \\
C .2 E \\
C .83 \\
C .95 \\
1.28 \\
C .6 \epsilon \\
C .85 \\
C .81 \\
C .72 \\
C .9 C \\
1.01 \\
1.2 C \\
1.92 \\
1.5 C \\
1.87 \\
C .43 \\
C .48 \\
1.14 \\
1 . C 4 \\
C .98 \\
1.18 \\
C .97 \\
C .9 C \\
1.75 \\
C .91 \\
1.03 \\
1.49 \\
1.08 \\
1.08 \\
C .95 \\
1.82 \\
1.1 \epsilon \\
C .87 \\
1.25 \\
C .88 \\
1.1 \epsilon \\
1.4 C \\
1.40 \\
C .93 \\
1.58 \\
1.59\end{array}$ & 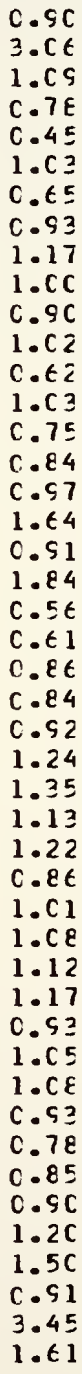 & 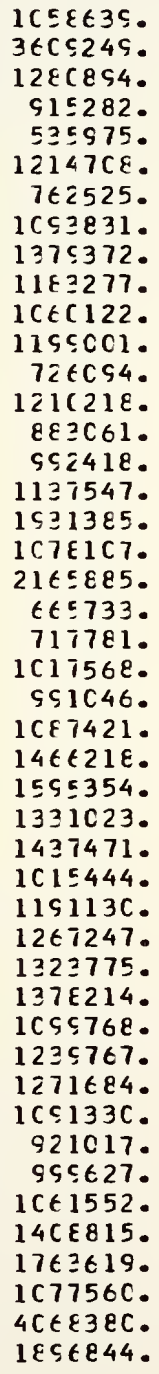 & $\begin{array}{r}127.81 \\
157.74 \\
74.27 \\
104.44 \\
133.88 \\
111.34 \\
228.57 \\
111.35 \\
123.69 \\
78.18 \\
136.24 \\
119.76 \\
76.02 \\
143.53 \\
82.98 \\
83.64 \\
8 C .54 \\
85.37 \\
57.59 \\
98.04 \\
136.47 \\
127.68 \\
75.57 \\
81.06 \\
54.62 \\
165.80 \\
14 C .21 \\
124.87 \\
69.67 \\
95.01 \\
98.44 \\
72.34 \\
164.40 \\
1 C 8.13 \\
98.21 \\
57.87 \\
92.90 \\
166.62 \\
62.65 \\
55.88 \\
77.73 \\
85.18 \\
166.77 \\
97.87 \\
217.82 \\
1 C 1.24\end{array}$ \\
\hline
\end{tabular}


TAELE A4. FUNC CISTRIBUTICN TO RURAL AREAS

CCLATY

\section{4}

48 MAC ISCN

49 NAR ICN

50 MAR SHALL

EI MARTIN

52 MIAPI

53 MCAFCE

54 MCNTGCNERY

55 MCR CAN

56 NEWTCA

57 ACEIE

$58 \mathrm{CHIC}$

59 CRANGE

EO CWEA

$t I$ FARKE

$t 2$ FERFY

$\in 3$ FIKE

64 FCR IER

t5 FOSEY

$t 6$ FUL $A S K I$

E 7 FUTAAN

68 RAALCLPF

G RIFIEY

70 RUSH

71 ST ...CSEFF

72 SCCTT

73 SHELEY

74 SPEPCER

T5 STAFKE

76 STELBEA

77 SULIIVAN

78 SWITZFRLANC

19 TIFIECANCE

EO TIFICA

E I UNICA

E 2 VAACERBUREH

E 3 VERPILLICA

E4 VIGC

E5 WAE /SH

E6 WARFEN

$\varepsilon 7$ WARFICK

\& 8 hAS INGTCA

E 9 WAYAE

SO WELIS

c) WHI IE

S2 WHITLEY
ALTERNATIVE 1

NEECS DFFICIT CCLLARS PERCENT

FORMULA CIST DIST/ DCLLARS DEFICIT $(\%)$

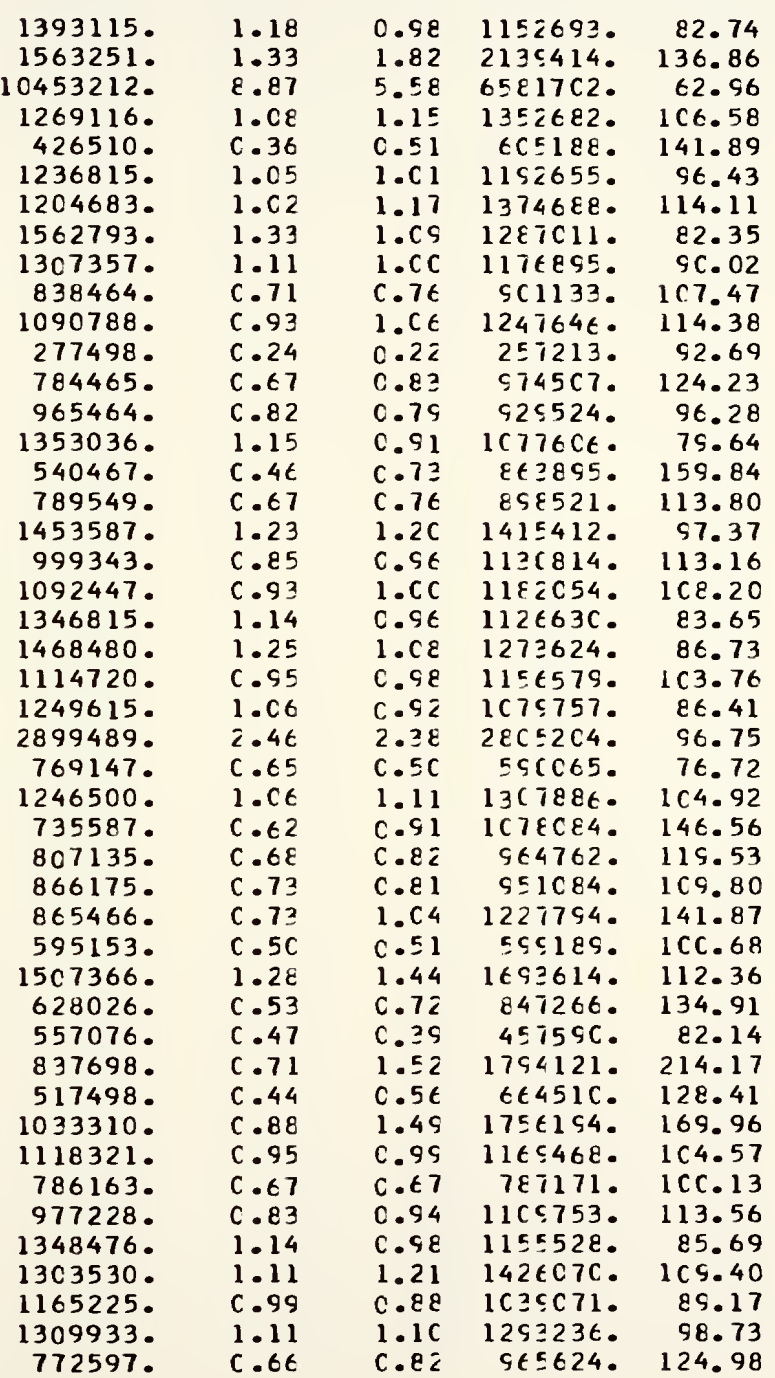


TAELE A5. FUNC CISTRIEUTICN TO RURAL AREAS

\begin{tabular}{|c|c|}
\hline & COUATY \\
\hline 1 & ADAAS \\
\hline 2 & ALLEA \\
\hline 3 & EAR IHCLCNEW \\
\hline 4 & EEATCN \\
\hline 5 & ELACKFCRI \\
\hline 6 & ECCAE \\
\hline 7 & ERC bN \\
\hline 8 & CARFCLL \\
\hline 9 & CASS \\
\hline 10 & CLAFK \\
\hline 11 & CLAY \\
\hline 12 & CLIATCA \\
\hline 13 & CRA $P F C R[$ \\
\hline 14 & CAVIESS \\
\hline 15 & CEAFBCRA \\
\hline 16 & CEC \&TUR \\
\hline 17 & CEK /LE \\
\hline 18 & CE I \& hARE \\
\hline 19 & CUE C IS \\
\hline 20 & ELKFART \\
\hline 21 & FAYETTE \\
\hline 22 & $F L C \backslash C$ \\
\hline 23 & FCUATAIA \\
\hline 24 & FRAAKL IA \\
\hline 25 & FUL ICN \\
\hline 26 & GIE $S C A$ \\
\hline$<7$ & GRAT \\
\hline$<8$ & CREEAE \\
\hline 29 & HAN ILTCA \\
\hline 30 & HAACCCK \\
\hline 31 & HAR F I SCA \\
\hline 22 & HEA [RICKS \\
\hline 23 & HEAFY \\
\hline 24 & HOh \& RC \\
\hline 3.5 & HUA II AGTCA \\
\hline 26 & JACKSCA \\
\hline 27 & JAS FER \\
\hline 38 & JAY \\
\hline 39 & JEF FERS C $A$ \\
\hline 40 & JEAAIAGS \\
\hline 41 & JOHASCN \\
\hline 42 & KNC \\
\hline 43 & KOSCIUSKC \\
\hline 44 & LAGFANGE \\
\hline 45 & LAKE \\
\hline 46 & LAPCRTE \\
\hline
\end{tabular}

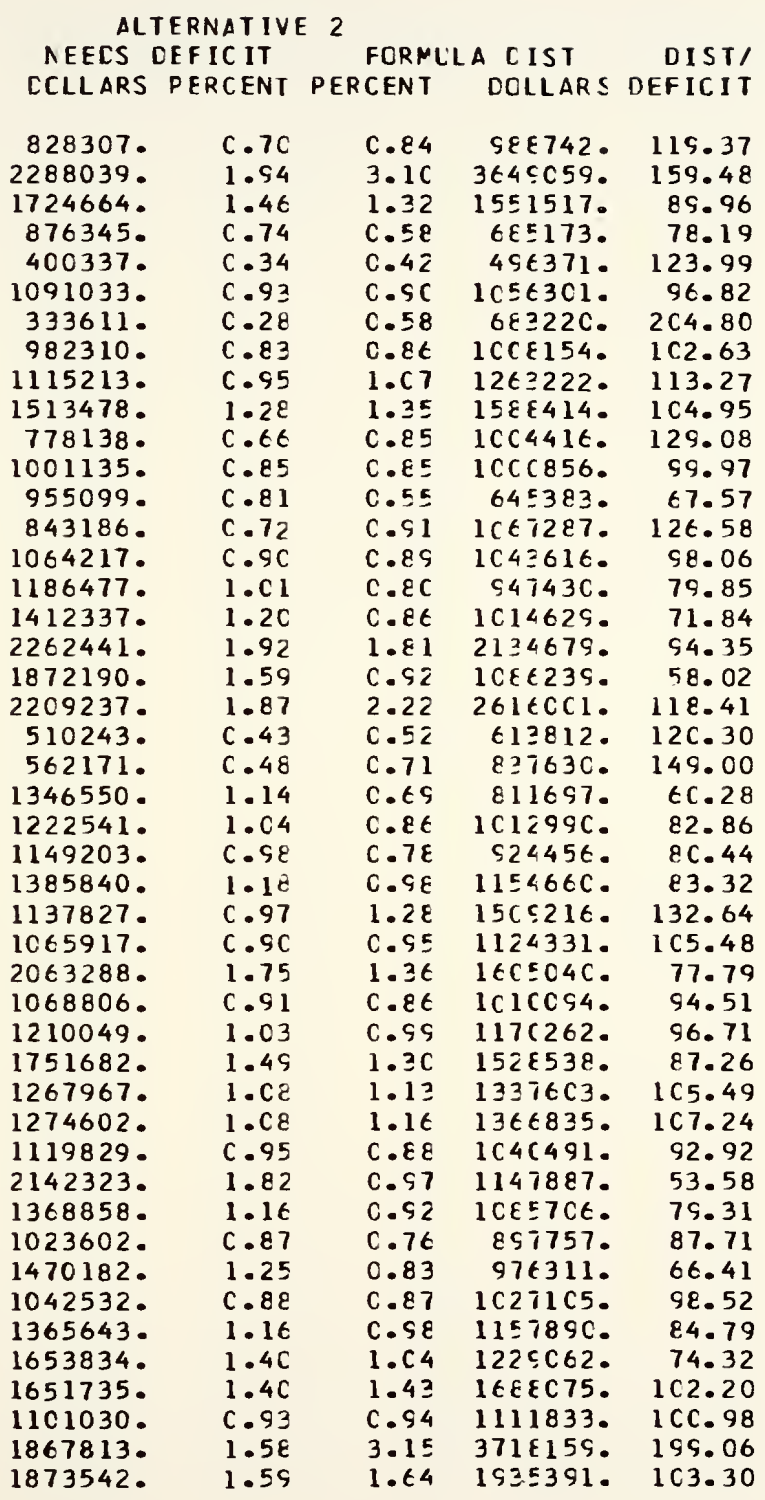


TAELE A5. FUNC CISTRIEUTICN TO RURAL AREAS

\section{CCUNTY}

47 LAYFEACE

48 MAC ISCA

49 MARICA

EO MAR SHALL

I MARIIA

5 2 IDAI

53 MCAFCE

54 MONTGENEFY

55 MCRCAN

56 AELTCA

57 ACEIE

$5.8 \mathrm{CHIC}$

59 CRANGE

EO CWEA

$\in 1$ FARHE

62 FERFY

63 FIKE

E4 FORTER

E5 FCS IY

EG FUL ISKI

E7 FUTIAN

\& 8 RANICLPH

G 9 RIFIEY

TO RUSt

71 ST. ICSEFH

72 SCCTT

73 SHEI $8 Y$

14 SPFACER

75 ST $\triangle F K E$

76 STELEFA

77 SULIIVAA

78 SWITZERLANC

79 TIFFECANCE

FO TIFTCA

EI LNICA

\& 2 VAA CERQUREH

E 3 VER ILLICA

E4 VIC C

E5 WAE ISH

E6 MARFEA

E7 hARFICK

\& 8 WASHINGTCA

EQ hAYNE

CO hELIS

S I WHITE

C2 HHI ILEY
ALTERNATIVE 2

AEECS CEFICIT FORMLLA DIST CCLLARS PERCENT PERCENT

CCLLARS DEFICIT

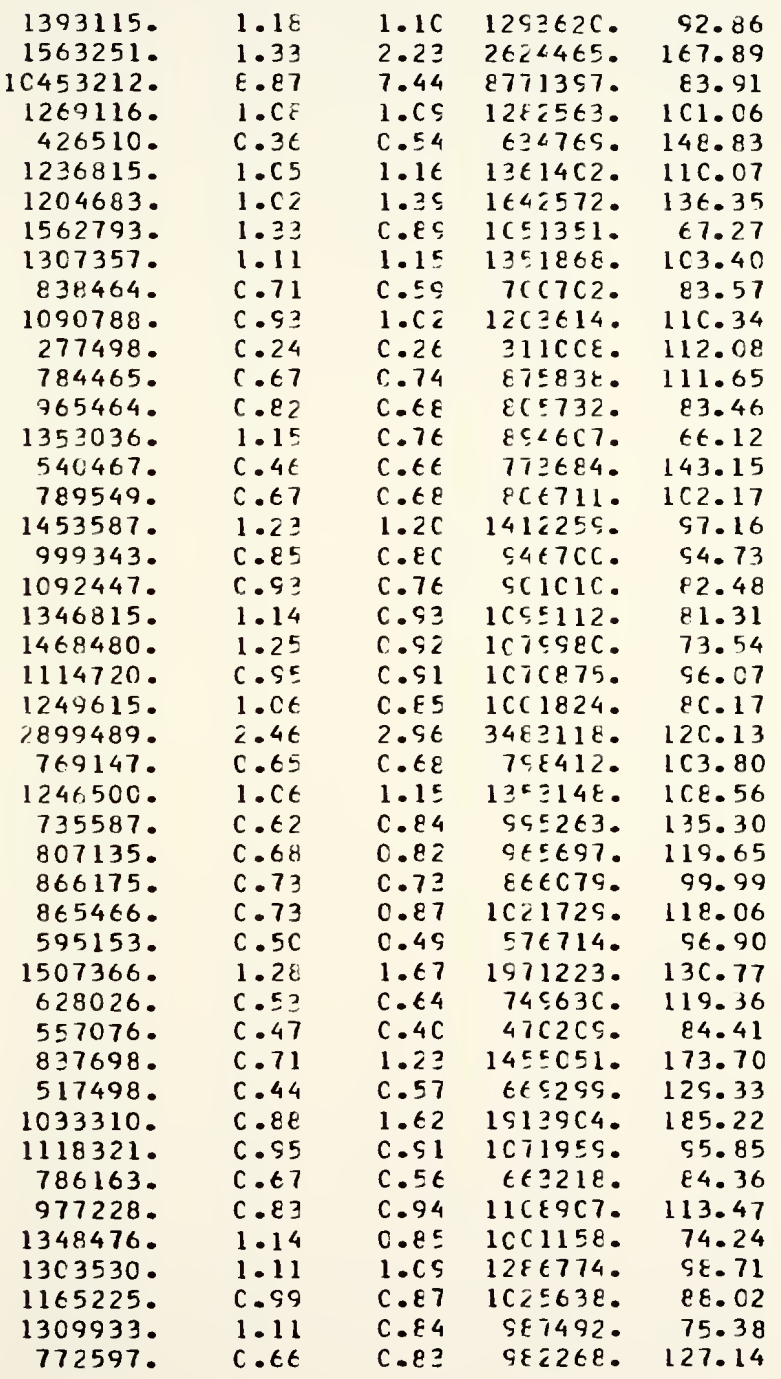


TIELE A6. FUAC CISTRIEUTICN TC RURAL AREAS

COLAT

$1 A D A P$

2 ALLEA

3 EAFTHCLCNEW

4 EEATCA

5 ELACKFCRE

6 ECC PE

7 ERC I

8 CARFCLL

9 CAS:

1 C CLAFK

$11 \mathrm{CLA}$ )

12 CLIATCA

13 CRAVFCRC

14 CAVIESS

15 CEAFECRA

16 CEC \&TUR

17 CEK 1 LK

18 CEL I $\triangle A R E$

19 CUETIS

$\angle C$ ELKFART

Z 1 FAYETTE

¿2 FLC YC

23 FLLATAIA

24 FRA KL $1 \mathrm{~A}$

$\therefore 5$ FULICA

26 GIESCA

27 GRANT

¿8 GREENE

¿9 FAN ILTCA

20 HAACCCK

31 HAR ISLA

32 HEALRICKS

23 HEAFY

$34 \mathrm{FCh} / \mathrm{RC}$

35 HUA IIAGTCA

26 JAC $\$ S C A$

$? 7$ JASFER

38 JAY

39 JEFFERSCA

4 C JEAMINGS

41 JCH ACA

$42 \mathrm{KNC}$ )

43 KCSCIUSKC

44 LACFANGE

45 LAKE

46 LAFERTE
ALTERNATIVE 3

NEECS DFFICIT FORMLLA CIST DISTI CCLLARS FERCENT PERCENT DULLARS DEFICIT

$(\%)$

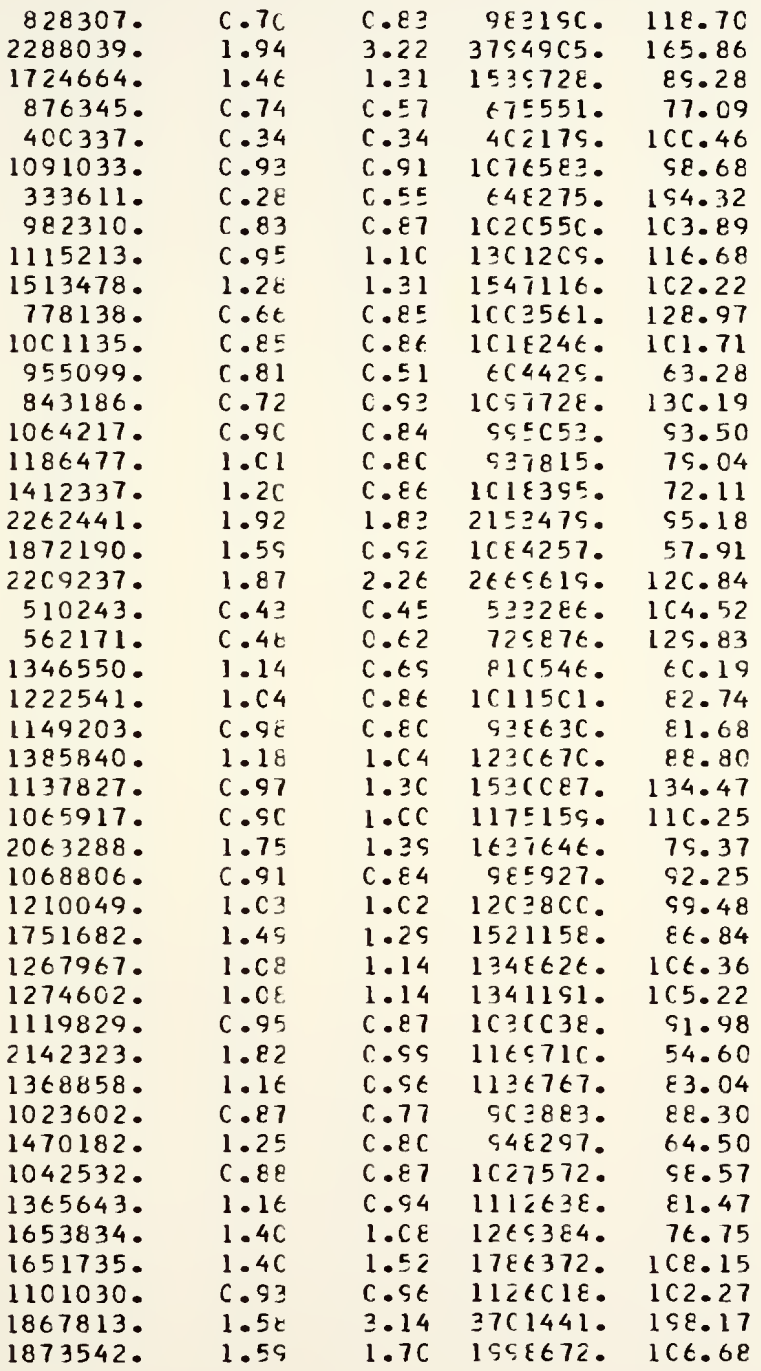


TAELE A6. FUAC CISTRIEUTICN TC RURAL AREAS

COUNY

47 LAWFEACE

48 NAC ISCA

49 MARICA

5O NARSHALL

EI MARTIN

E2 MIAMI

53 MCAFCE

54 NCA TCCNEFY

55 MCRCAA

56 AEKICA

57 NOELE

58 CHIC

59 CRANGE

EO CWEA

E 1 FARME

E 2 FERFY

63 FIK F

t4 FCRTER

E 5 FOSFY

6 FUL $/ S K I$

ET FUTAAN

E 8 FAACCLPH

$\in g$ PIFIEY

$7 \mathrm{C}$ PUSt

71 ST..CSEFF

72 SCCIT

73 SHE IEY

74 SPEACER

75 ST $\triangle F K E$

76 STELEEA

77 SULLIVAA

78 SWITZFRLAAC

79 TIPFECAACE

EO TIFICA

\& I LNICA

E 2 VAA EERELREF

E 3 VEFPILLICA

\& 4 VIGC

E 5 hAE 2 SH

E6 hARFEA

E 7 hARFICK

$\& 8$ hAS INGTCA

E 9 hAYPE

SO hELIS

C 1 WHI IE

c. 2 WHITLEY

\author{
ALTERNAT IVE 3 \\ AEECS DFFICIT \\ CCLLARS PERCENT \\ FORMLLA CIST DIST/ $(\%)$
RCENT DCLLARS DEFICIT
}

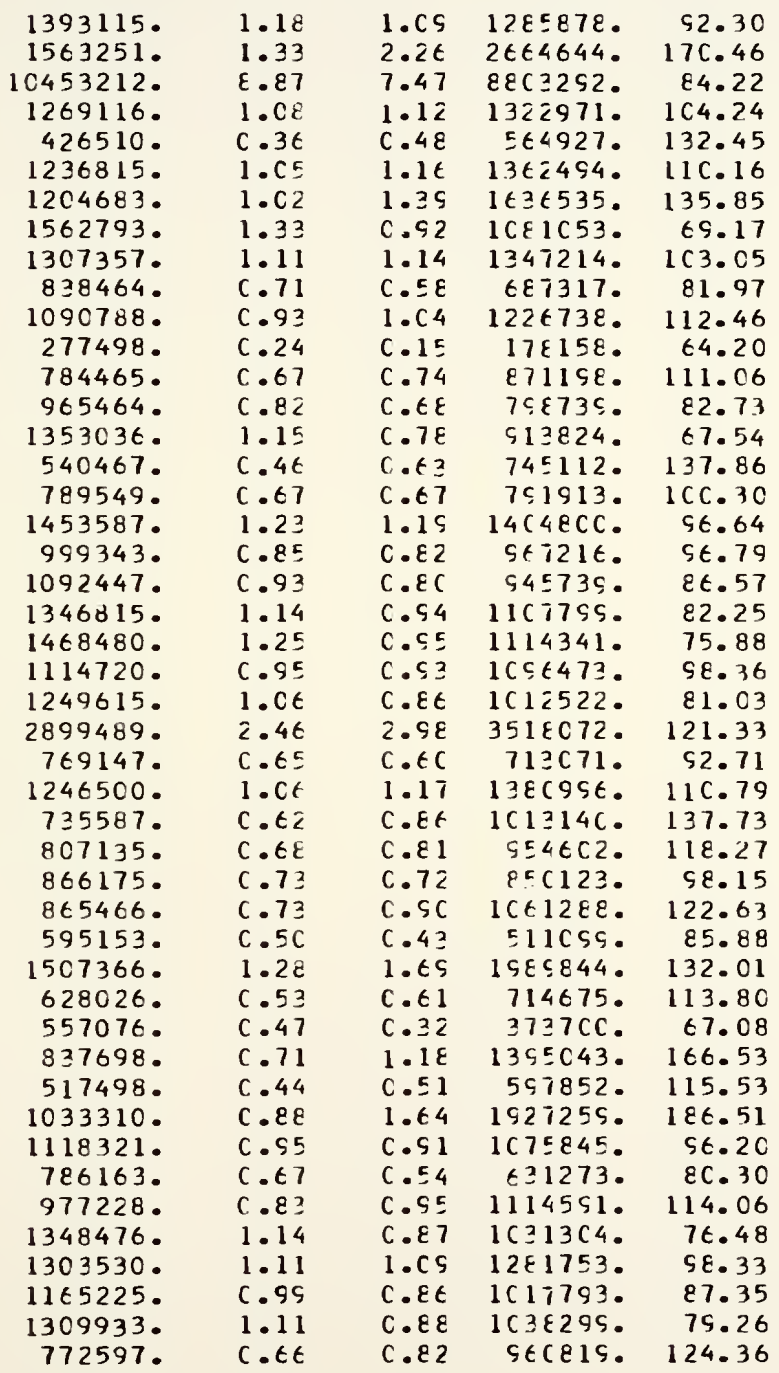


TABLE A7. TCTAL FUND CISTRIEUTICN TO COLNTY

COLATY

1 ACANS

ALLEA

3 PARTHCLCNEW

4 EEATCA

5 ELACKFCPC

6 PCCAE

7 ERCWA

8 CAR ICLL

9 CAS

1 C CLAFK

11 CLAS

12 CLIMTCA

13 CRALFCRL

14 CAVIESS

15 CEAFECRA

16 CEC ITUR

17 CEKILE

$1 \&$ CEL IWARE

19 CUECIS

¿O ELK+ART

21 FAYETTE

22 FLCYC

23 FCLNTAIA

24 FRAMKLIA

is FULICA

¿6 G1ESCA

27 CRAPT

28 CREEAE

29 HAN ILTCA

$3 C$ HAACCCK

31 HARFISCA

22 HEAIRICKS

$? 3$ HEAFY

34 FCh IRC

35 HUA TIAGTCA

36 JACKSCA

27 JASFER

$? 8$ JAY

29 JEFFERSCA

40 JEARINGS

41 JOHASCA

$42 \mathrm{KNC}$ )

43 KCSCIUSKC

44 LACFAAGE

45 LAKE

46 LAFCRTE
ALTERNATIVE I

AEECS CFFIC IT CCLLARS FERCENT

FCRMLLA CIST DIST/
RCENT DOLLARS DEFICIT

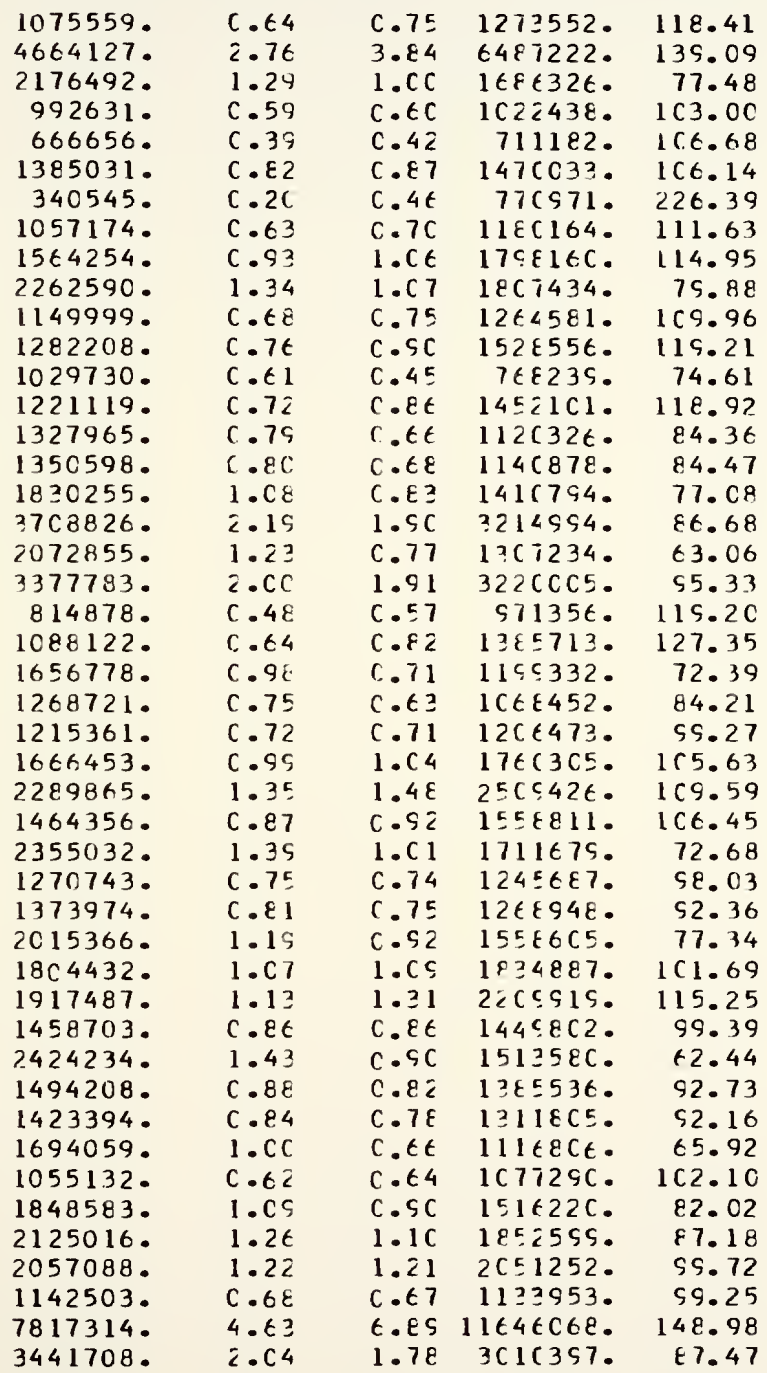


TAELE A7. TCTAL FUND CISTRIEUTICN TO COLNTY

COUATY

47 LAWFENCE

48 MACISCA

49 MAR ICN

5C MARSHALL

51 MARTIN

52 MAPI

53 MCAFCE

54 NCATGCMERY

55 NCRCAA

56 AEWTCA

57 ACE IE

ᄃ $8 \mathrm{CHIC}$

- 9 CRAAGE

EC CWEP

$E I$ FARKE

$t 2$ FERFY

63 FIKE

E4 FCRTER

$\in 5$ FCSEY

$t 6$ FUL $1 S K I$

E7 FUTAAN

E 8 RANCCLPF

$\in 9$ RIFIEY

70 RUSt

71 ST..CSEFF

72 SCC TT

73 SHE IEY

74 SPFACER

75 ST $\triangle F K E$

76 STEIREN

77 SULLIVAA

78 SWI IZERLAAC

79 IIFFECANCE

EO TIF TCA

$\varepsilon I$ UNICA

E 2 VAAIERELREH

\& 3 VER ILLICA

\&4 VIGC

\& 5 WAE \&SH

E6 hARFEA

$\varepsilon 7$ hARFICK

E 8 hASH IAGTCA

89 MAYAE

CC hELIS

\I HHI IE

ऽ2 HHITLEY
ALTEFNAT IVE 1

AEECS CFFICIT FORMLLA CIST DIST/ CCLLARS PERCENT PERCENT DCLLARS DEFICIT $(\%)$

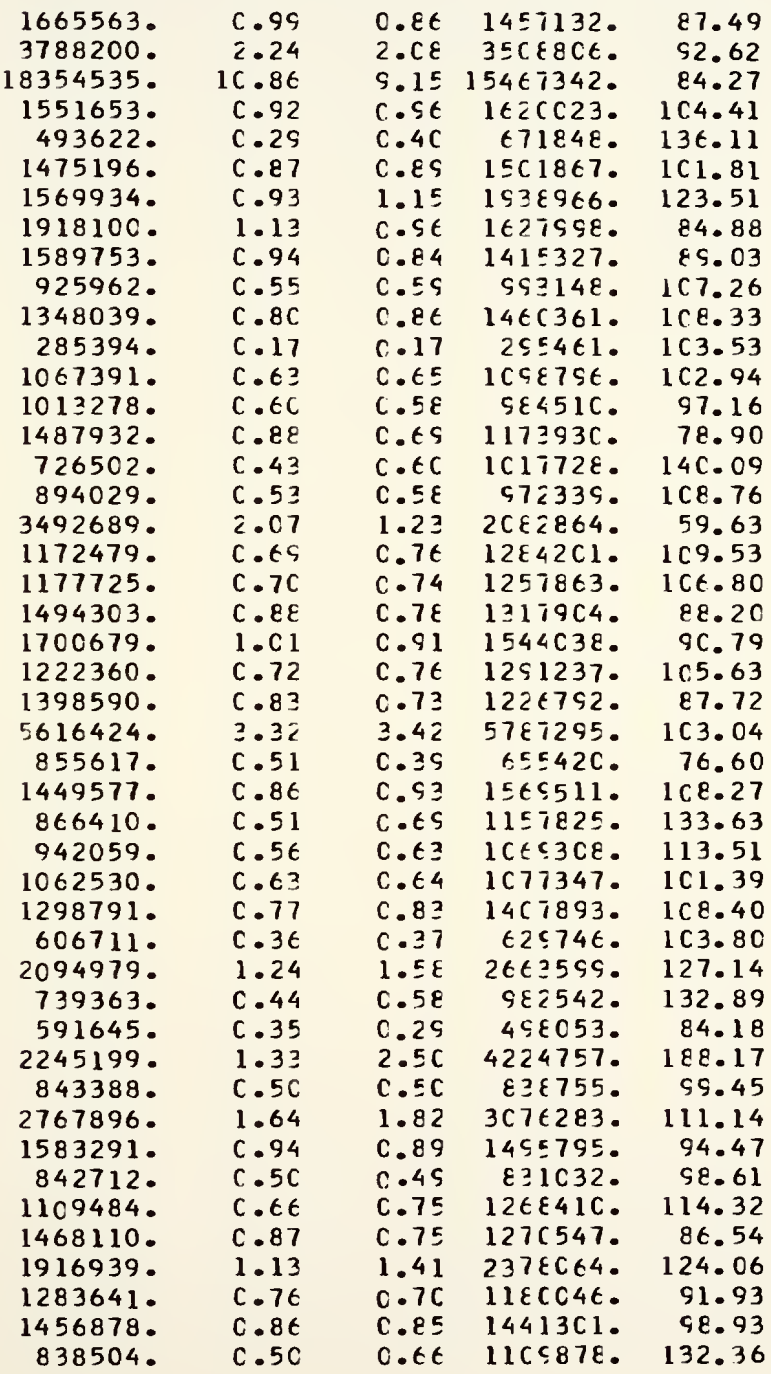


TAELE A8. TOTAL FUNC CISTRIRUTICN TO COUNTY

COUTY

1 ADAPS

2 ALLEA

3 EAR THCLCNEW

4 EENTCA

5 ELACKFCFC

6 ECCIE

7 ERC $1 A$

8 CARFCLL

9 CASS

10 CLA K

11 CLAY

12 CLINTCA

13 CRAVFCRL

14 CAVIESS

15 CEAFECRA

16 CEC ITUR

17 CEK ILE

18 CEL I HARE

19 CUECIS

20 ELKFART

21 FAYETTE

22 FLCIC

23 FCL MTAIA

24 FRAAKLIA

25 FULICA

26 GIESCA

27 ERANT

28 CRE IAE

29 HAF ILTCA

30 HANCCCK

31 HAR FISCA

22 HEALRICKS

33 HEAFY

$34 \mathrm{HCh} / \mathrm{RC}$

25 HUA IINGTCA

36 JACISCA

37 JASFER

28 JAY

39 JEFFERSCA

40 JEANIAGS

41 JCHASCA

42 KNC)

43 KOS CIUSKC

44 LAGFANGE

45 LAKE

46 LAPCRTE
ALTERNAT IVE 2

AEECS DEFICIT FORMLLA CIST DISTI CCLLARS FERCENT PERCENT DCLLARS DEFICIT

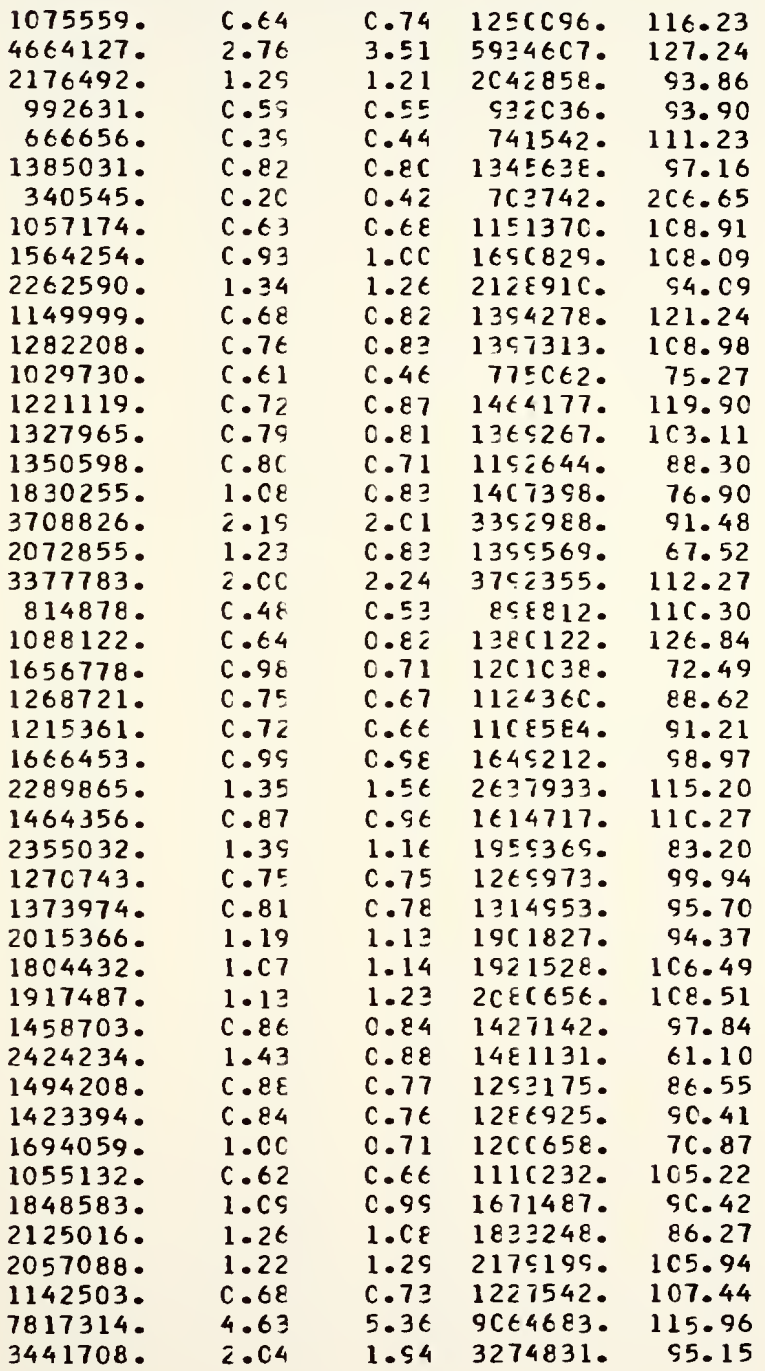


TAELE A8. TCTAL FUNC CISTRIEUTION TO COLNTY

COUNTY

47 LAKFEACE

48 MAC ISCA

49 MARICA

SO MAR SHALL

51 MARTIA

52 MIAI

53 MCAFCE

54 MONTGCNEFY

55 MCREAA

56 NEW TCA

57 ACEIE

5.8 CHIC

S CRANGE

tO CWEA

$E I$ FAFRE

E 2 FERFY

$t 3$ FIKE

t4 FCR IER

$E 5$ FCS EY

t6 FUL ISKI

E 7 FUTHAN

E 8 RANLCLPF

\& RIFIEY

iC RUSt

71 ST. ICSEFF

72 SCCIT

73 SHEIEY

74 SPEPCER

75 ST AFKF

76 STELEEA

77 SULLIVAA

78 SWITZERLANC

79 TIPFECANCE

FO TIFICA

EI LNICA

E 2 VANCERELFEH

\&3 VERPILLICA

\& $\triangle$ VIG

E 5 WAE $\angle S H$

86 WARFEA

E 7 hARFICK

\& 8 WASH INGTCA

\& 9 hAYPE

CO hELIS

C 1 HHITE

C2 HHI TLEY
ALTERNATIVE 2

AEECS DEF IC IT CCLLARS PERCENT

FORMLLA CIST DCLLAR S DEFICIT

DIST/ $(\%)$

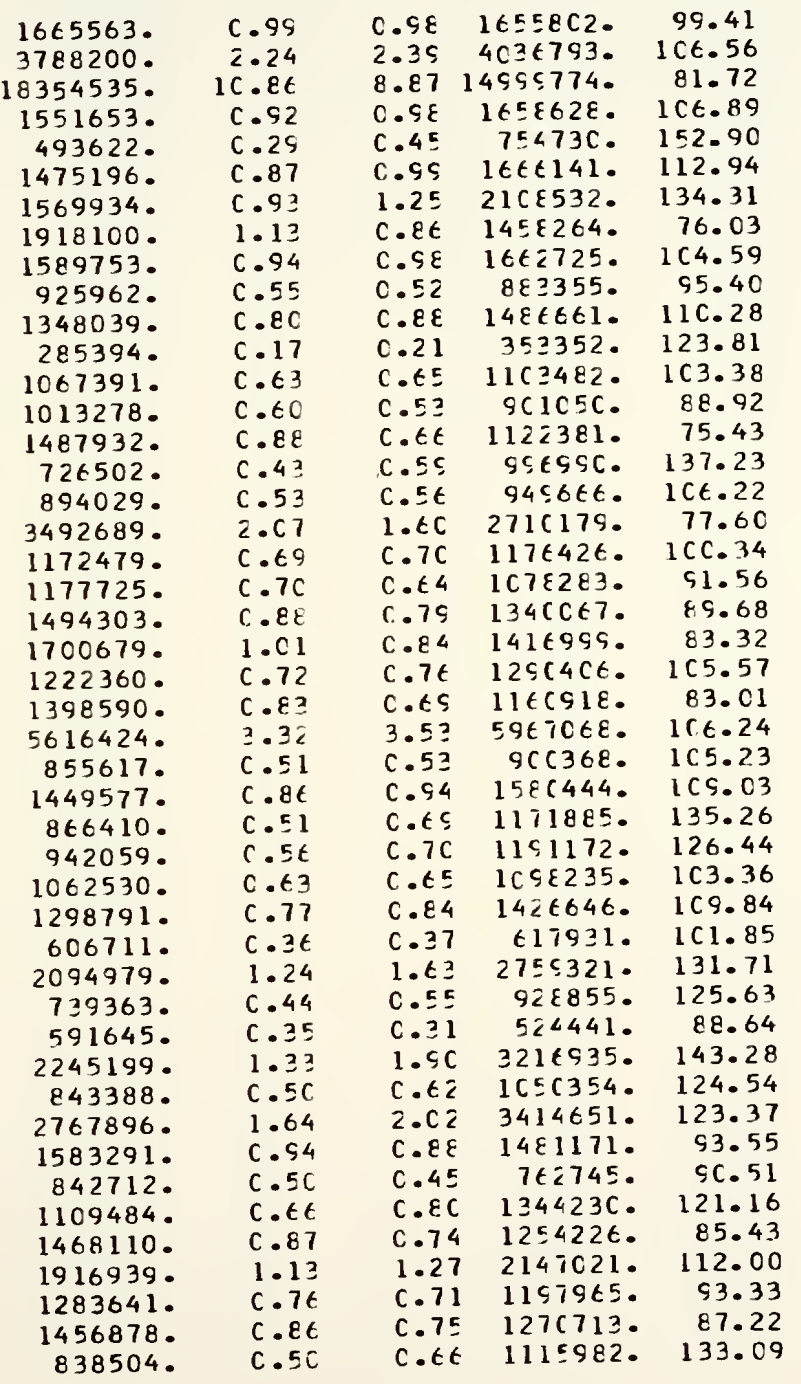


TAELE A9. TCTAL FUND CISTRIEUTICN TO COLNTY

CCLATY

1 ACAPS

2 ALLEN

3 EARTHCLCNEW

4 REATCA

5 ELACKFCFC

6 ECCAE

7 ERC $+A$

8 CAFFCLL

9 CAS S

1C CLAFK

11 CLA)

12 CLINTCA

13 CRA VFCRC

14 CAVIESS

15 CEAFECRA

16 CEC ITUR

17 CEK ILE

18 CEL / WARE

19 CUECIS

20 ELKFART

21 FAYETTE

22 FICIC

23 FCLATAIA

¿4 FRA MKLIA

25 FULTCA

26 EIESCA

27 ERANT

28 EREEAE

¿9 HAN ILTCA

3 HAACCCK

31 HAR ISCA

22 HEA IRICKS

33 HENFY

34 HOK IRC

35 HUA IIAGTCA

36 JACKSCN

37 JASIER

28 JAY

39 JEFFERSCA

$4 \mathrm{C}$ JFA I I GS

41 JUHASCA

42 KNC?

43 KOS IIUSKC

44 LAG FANGE

45 LAKE

46 LAFCRTE
ALTERNATIVE 3

AEECS CFFICIT FDRMLLA DIST DISTI (\%) CCLLARS FERCENT PERCENT DCLLARS DEFICIT

\begin{tabular}{|c|c|c|c|c|}
\hline 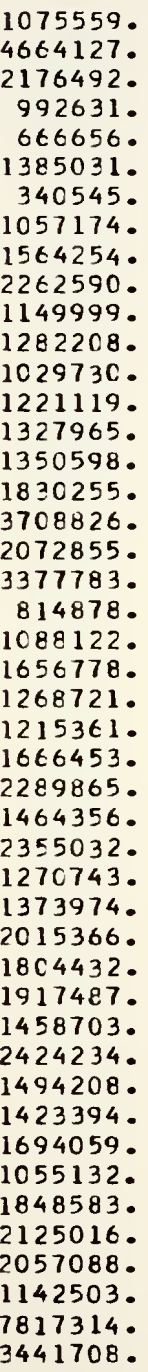 & 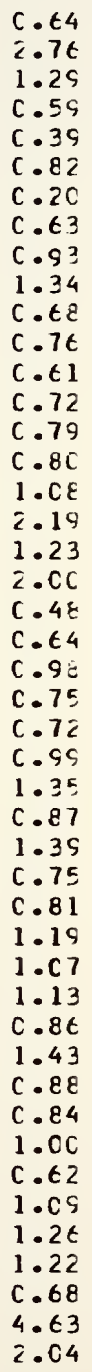 & $\begin{array}{l}C .74 \\
3.74 \\
1.1 t \\
C .5 C \\
C .3 E \\
C .81 \\
C .44 \\
C .7 C \\
1 . C 3 \\
1.28 \\
C .75 \\
C .82 \\
C .43 \\
C .82 \\
C .7 t \\
C .6 E \\
C .75 \\
1.57 \\
C .81 \\
2.16 \\
C .52 \\
C .82 \\
C .62 \\
C . t 5 \\
C .6 t \\
C .92 \\
1.41 \\
C .8 t \\
1.16 \\
C .75 \\
C .8 C \\
1.1 C \\
1.1 C \\
1.2 t \\
C .83 \\
C .88 \\
C .7 E \\
C .7 C \\
C .71 \\
C .7 C \\
C .54 \\
1 . C 2 \\
1.25 \\
C .74 \\
t . C 5 \\
1.75\end{array}$ & 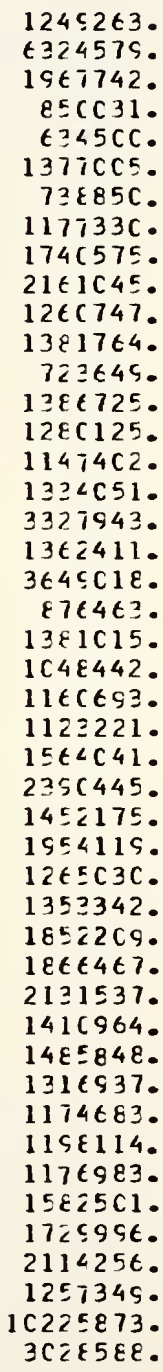 & $\begin{array}{r}116.15 \\
135.60 \\
9 C .41 \\
85.63 \\
55.18 \\
59.42 \\
216.96 \\
111.37 \\
111.27 \\
95.51 \\
1 C 5.63 \\
1 C 7.76 \\
76.28 \\
113.56 \\
56.40 \\
84.96 \\
72.89 \\
89.73 \\
65.73 \\
1 C 8.03 \\
1 C 7.56 \\
126.92 \\
63.28 \\
51.49 \\
52.42 \\
53.85 \\
1 C 4.39 \\
99.17 \\
82.98 \\
95.55 \\
98.50 \\
91.90 \\
1 C 3.44 \\
111.16 \\
56.73 \\
61.29 \\
88.14 \\
82.53 \\
7 C .72 \\
111.55 \\
85.61 \\
81.41 \\
1 C 2.78 \\
11 C .05 \\
13 C .81 \\
88.00\end{array}$ \\
\hline
\end{tabular}


TAELE A9. TOTAL FUND DISTRIBUTION TO COUNTY

COUATY

47 LAHFENCE

48 MADISCN

49 MAR ICN

50 MAR SHALL

51 MAR IIN

52 MIAPI

53 MONFCE

54 MON TGCMERY

55 MOREAN

56 NEWTCN

57 NDELE

58 CHI C

59 CRAAGE

tO CWEP

EI FARIE

62 PERFY

C3 FIKE

C4 FORTER

65 POSEY

66 PULASKI

67 FUTRAY

68 RANCCLPH

t9 RIPLEY

70 RUSP

71 ST . ICSEFH

72 SCCTT

73 SHELEY

74 SPERCER

75 STAFKE

76 STELBEN

77 SULLIVAN

78 SWI TZERLAND

79 TIP FECANCE

QO TIPTON

$\varepsilon 1$ UNI CN

E 2 VANCERBURGH

E 3 VERPILLICN

E4 VIGC

E 5 WAE ASH

66 MARFEN

87 WARFICK

Q 8 WASHINGTCN

E 9 WAYAE

SO MELIS

51 WHI TE

S2 WHITLEY
ALTERNATIVE 3

NEECS DEFICIT FORMULA DIST DIST/ CCLLARS PERCENT PERCENT DOLLARS DEFICIT

\begin{tabular}{|c|c|c|c|c|}
\hline 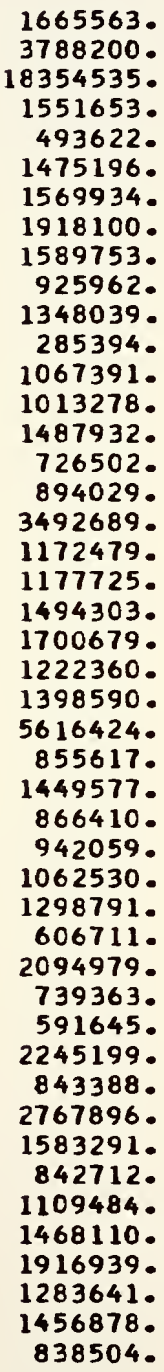 & $\begin{array}{l}C .99 \\
2.24 \\
1 C .86 \\
C .92 \\
C .29 \\
C .87 \\
0.93 \\
1.13 \\
C .94 \\
C .55 \\
C .8 C \\
C .17 \\
C .63 \\
0.6 C \\
C .88 \\
C .43 \\
0.53 \\
2.07 \\
C .69 \\
C .70 \\
C .88 \\
1.01 \\
C .72 \\
C .83 \\
3.32 \\
C .51 \\
C .86 \\
C .51 \\
C .56 \\
C .63 \\
C .77 \\
C .36 \\
1.24 \\
C .44 \\
C .35 \\
1.33 \\
C .50 \\
1.64 \\
C .94 \\
C .50 \\
0.66 \\
0.87 \\
1.13 \\
C .76 \\
C .86 \\
0.50\end{array}$ & $\begin{array}{l}0.96 \\
2.31 \\
9.73 \\
0.97 \\
0.42 \\
1.01 \\
1.3 C \\
0.86 \\
0.97 \\
0.5 C \\
0.88 \\
0.17 \\
0.63 \\
0.55 \\
0.64 \\
0.57 \\
0.56 \\
1.22 \\
0.7 C \\
0.65 \\
0.80 \\
0.84 \\
0.77 \\
0.72 \\
3.63 \\
0.5 C \\
1.00 \\
0.65 \\
0.67 \\
0.62 \\
0.77 \\
0.37 \\
1.71 \\
0.54 \\
0.29 \\
2.1 C \\
0.49 \\
1.85 \\
0.85 \\
0.44 \\
0.79 \\
0.72 \\
1.29 \\
0.72 \\
0.74 \\
0.69\end{array}$ & 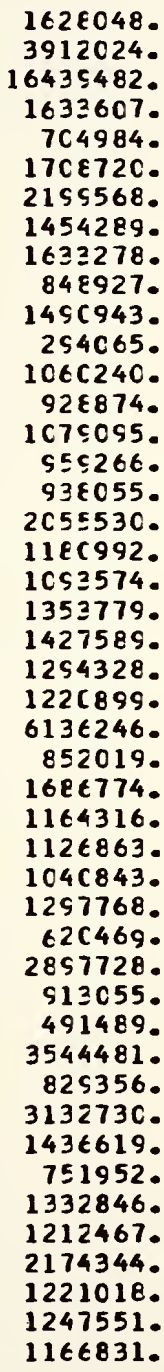 & $\begin{array}{r}97.75 \\
103.27 \\
89.57 \\
105.28 \\
142.82 \\
115.83 \\
140.11 \\
75.82 \\
102.74 \\
91.68 \\
110.60 \\
103.04 \\
99.33 \\
91.67 \\
72.52 \\
132.04 \\
104.92 \\
58.85 \\
100.73 \\
92.85 \\
90.60 \\
83.94 \\
105.89 \\
87.29 \\
109.26 \\
99.58 \\
116.36 \\
134.38 \\
119.62 \\
97.96 \\
99.92 \\
102.27 \\
138.32 \\
123.49 \\
83.07 \\
157.87 \\
98.34 \\
113.18 \\
90.74 \\
89.23 \\
120.13 \\
82.59 \\
113.43 \\
95.12 \\
85.63 \\
139.16\end{array}$ \\
\hline
\end{tabular}


APPENDIX B: FINANCING AND NEEDS PROGRAMS, 1966-1985 


\section{APPENDIX B: FINANCING AND NEEDS PROGRAMS, 1966-1985}

\section{Description of Tables}

Tables B 1 to $B 3$ represent the financial needs, revenues and resulting backlog for the twenty year needs period, with no tax increase.

Tables B4 to $B 6$ represent the financial needs and required revenues for an improvement program intended to eliminate the needs backlog within twenty years.

Table B7 represents the needs and required borrowing for a 10-year catch-up program for the state highway system. 
- $\quad \dot{0} \dot{0} \dot{0} \dot{0} \dot{0} \dot{0} \dot{0} \dot{0} \dot{0} \dot{0} \dot{0} \dot{0} \dot{0}$ in $0 \backsim \infty m \sigma m \rightarrow r m \infty R m m$ n

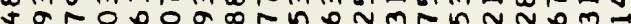

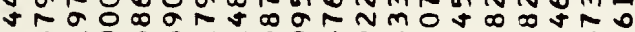

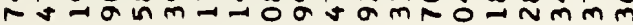

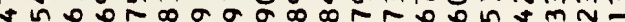

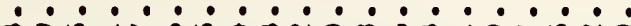

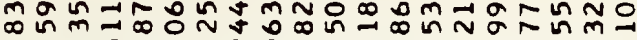

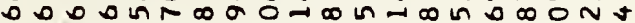

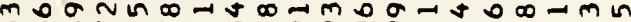

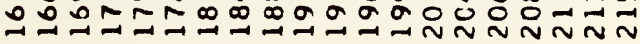

$\simeq$

品

ல் $\dot{0} \dot{0} \dot{0} \dot{0} \dot{0} \dot{0} \dot{0} \dot{0} \dot{0}$

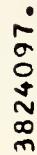

$\frac{5}{x}$

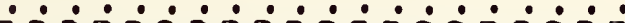
$\sin \sigma \sigma \sigma \sigma \sigma$

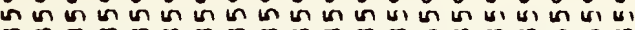
mm mmmmmmmmmmmmmmmmm rantratratarantatara

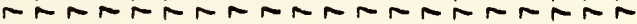

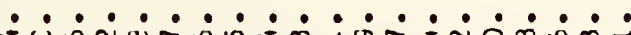
至岂 NUก nNa U

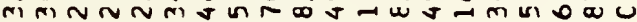
u以nuw

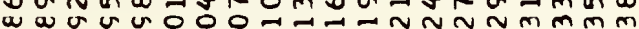
(⿻上丨)

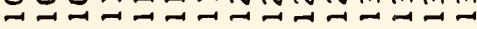

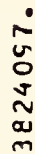
$\leftarrow$

学

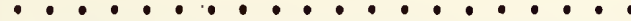
+mn-an-rinanomonamio

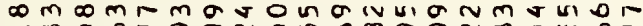

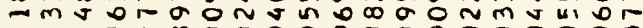

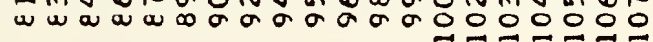

告

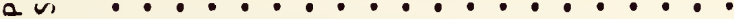

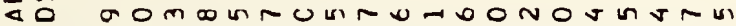

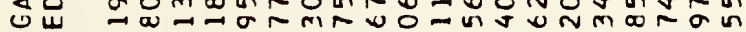

a

O 2

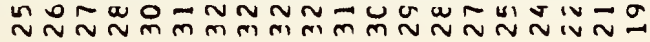
n

$n$
$n$
$n$

Е

里

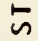

लं

$\sum_{x} n$

我

U $\stackrel{2}{2}$

$\cdot \cdot \cdot \cdot \cdot \cdot \cdot \cdot \cdot \cdot \cdot \cdot \cdot \cdot \cdot \cdot \cdot \cdot \cdot \cdot \cdot \cdot$

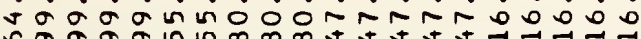

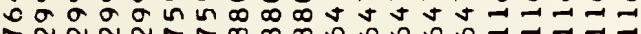

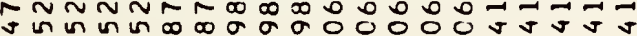

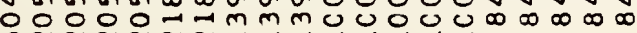

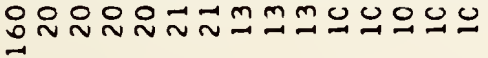

$\stackrel{x}{2}$

ON- $\sigma 0-N m$ s - 00 or

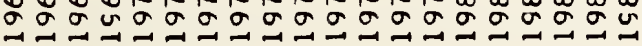

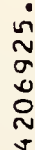




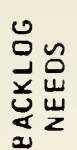

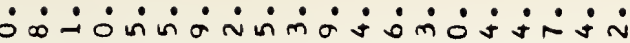

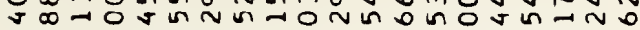
$\sigma \wedge n-m \infty \sim-1-N \sigma N \rightarrow \infty m 00 m$ n $\rightarrow 0$ ON

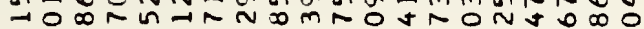

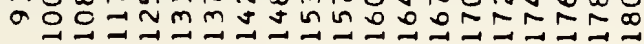

- $\dot{0} \dot{0} \dot{0} \dot{0} \dot{0} \dot{0} \dot{0} \dot{0} \dot{0} \dot{0} \dot{0} \dot{0}$ N N N NOO

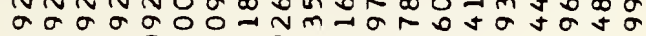

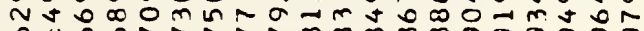

$\dot{0} \dot{0} \dot{\sim} \dot{\sim} \dot{\sim} \dot{\sim} \dot{\sim} \dot{\sim} \dot{\sim} \dot{\sim} \dot{\sim} \dot{\sim} \dot{\sim} \dot{0} \dot{\sim} \dot{\sim}$ in NニNト

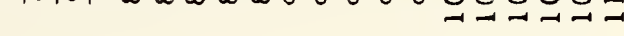

$\cdot \cdot \cdot \cdot \cdot \cdot \cdot \cdot \cdot \cdot \cdot \cdot \cdot \cdot \cdot \cdot \cdot \cdot$ $\sim N N \sim \sim N N \sim N N N N N N \sim N N \sim N$ जा जा जा जा जा जी जा जा जा जा जा जा जा जा जा जर खा जो जा जा जा जा जा जा जा जा जा जा जा जा जा जा

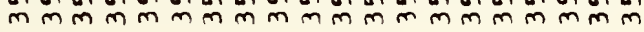

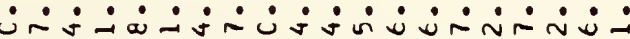
N $\rightarrow \exists u$ a

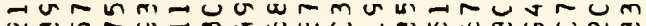
(v n)

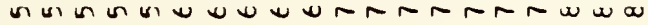

Z $\sum \backsim$

世

$\cup$ $\vec{z}$

$\dot{0} \dot{0} \dot{0} \dot{0} \dot{0} \dot{0} \dot{0} \dot{0} \dot{0} \dot{0} \dot{0} \dot{0} \dot{0} \dot{0}$ $r u-\pi u w \cup m$ w - w $\rightarrow$ - iv

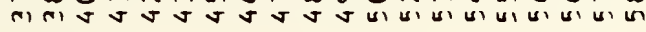
u.

a u c a w 음 in

$\cdot \cdot \cdot \cdot \cdot \cdot \cdot \cdot \cdot \cdot \cdot \cdot \cdot \cdot \cdot \cdot \cdot \cdot \cdot \cdot$

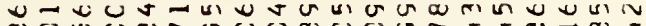

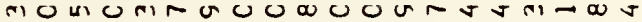

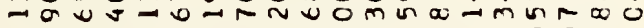
w w

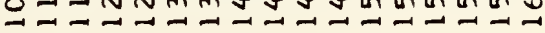

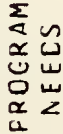

- $\cdot \dot{0} \cdot \dot{0} \dot{0} \dot{0} \dot{0} \dot{0} \dot{0} \dot{0}$ ก

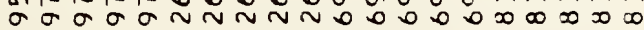

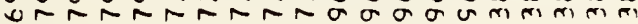

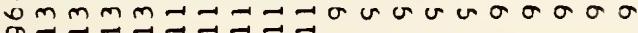

U

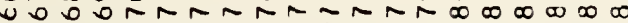

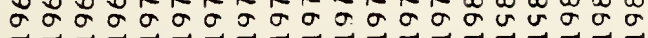




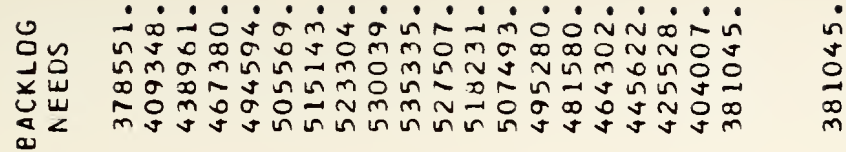

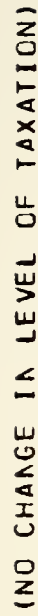

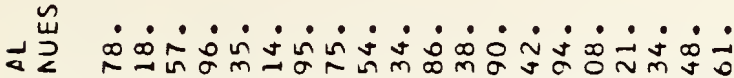

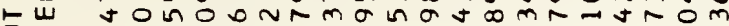

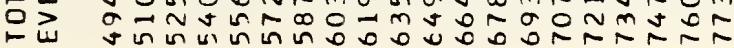

$\stackrel{\omega}{\longrightarrow}$

- $\dot{0} \dot{0} \dot{0} \dot{0} \dot{0} \dot{0} \dot{0} \dot{0} \dot{0} \dot{0} \dot{0}$

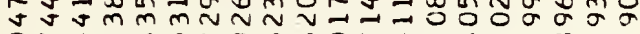

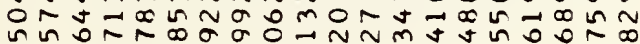
$\sim \sim N N \approx N \sim N m m m m m m m m m m$



N

ت ن

$a$
0
$m$
$n$
$i$
0
0

की

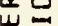

एव

$\dot{1}$
$\vdots$
0
$\infty$
$m$

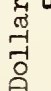

$\dot{0} \dot{0} \dot{0} \dot{0} \dot{0} \dot{0} \dot{0} \dot{0} \dot{0} \dot{0} \dot{0} \dot{0}$

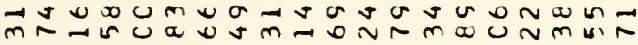

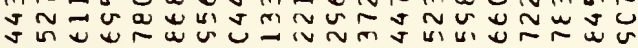

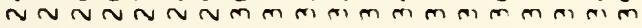

$\dot{0}$
$\infty$
$\tilde{2}$
$\tilde{n}$ 岕

$\cdot \cdot \cdot \cdot \cdot \cdot \cdot \cdot \cdot \cdot \cdot \cdot \cdot \cdot \cdot \cdot \cdot \cdot \cdot 0$

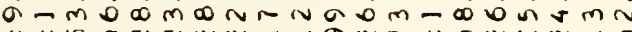
un und

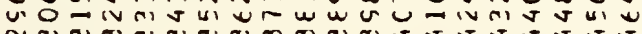

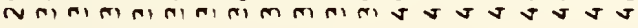

造帒

ن넨

证

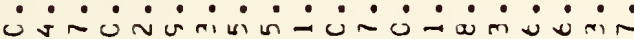
แn $\pi$ a

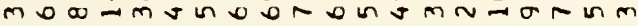

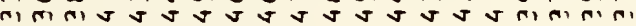

$\dot{0} \dot{0} \dot{0} \dot{0} \dot{0} \dot{0} \dot{\sigma} \dot{\sigma} \dot{0} \dot{0} \dot{0} \dot{0}$

$\simeq 0$

w

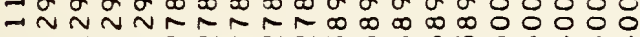

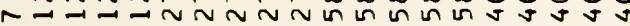

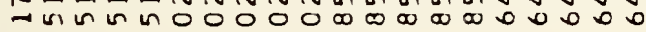
व $<$ g

Ш 
பே 崖 范 Uz 年 J य -

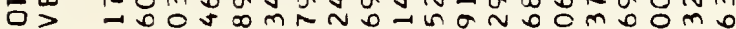

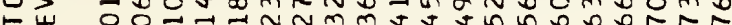
a N N N N N N N N N N N N N N N N N N

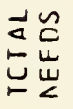

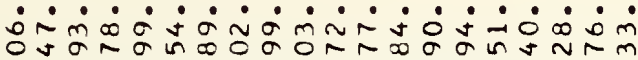

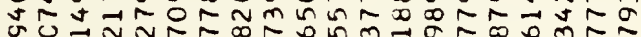
matytunR on $N \sim \sim N \rightarrow \rightarrow-\rightarrow-\longrightarrow \rightarrow-\rightarrow \rightarrow-1$ $\stackrel{1}{\circ}$

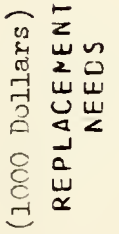

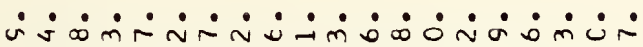

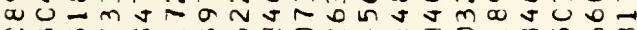

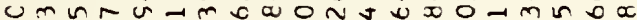

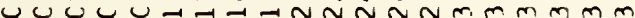

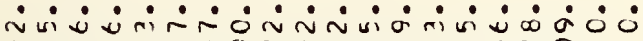

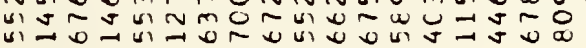

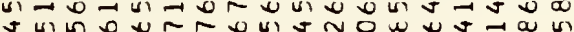

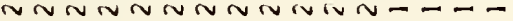

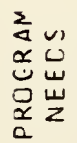

$\therefore \dot{0} \dot{0} \dot{0} \dot{0} \dot{0} \dot{0} \dot{0} \dot{0} \dot{0} \dot{0} \dot{0} \dot{0}$

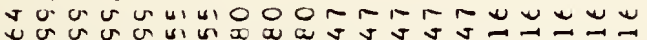

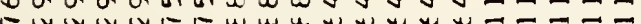

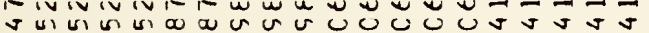
o 0 u v mivivivivin-m-- - - - - 


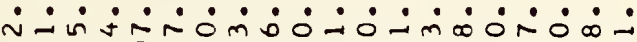

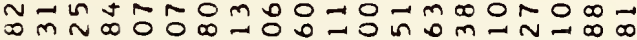

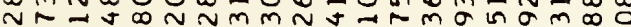
N

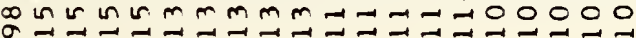

$\dot{0} \dot{0} \dot{0} \dot{0} \dot{0} \dot{0} \dot{0} \dot{0} \dot{0} \dot{0} \dot{0} \dot{0}$

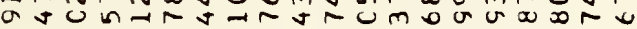

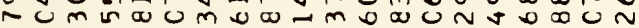

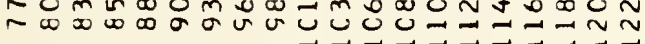

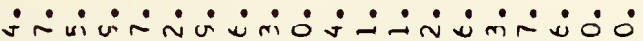
av แล

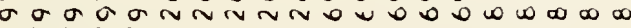

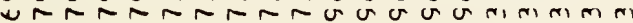
um mm 


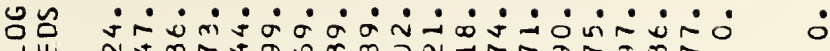
ᄀu num

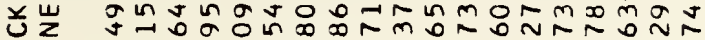

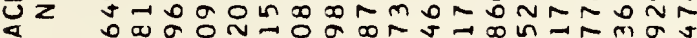

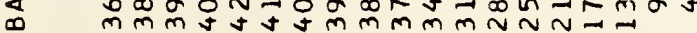

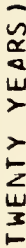
य 네

$z$

बढ

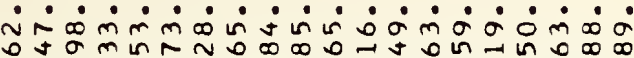
ᄂ

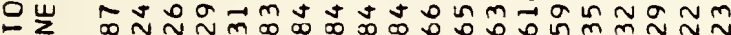
$N \infty \infty \infty \infty 00000$ แn แn I

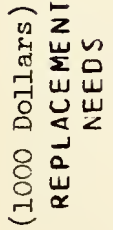

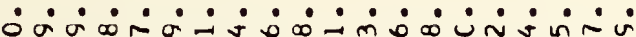

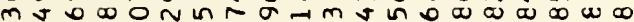

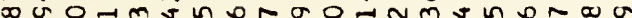

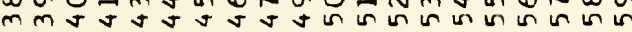

$\stackrel{\alpha}{a} \mathbb{u}$

$\mapsto$

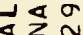

$\rightarrow 2$

$\underset{2}{2}$

$\therefore \rightarrow 4$

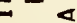

$1 \square \stackrel{4}{4}$

$\sum_{\|} \frac{\sigma}{z}$

$0 \cup 1=$

$\alpha$

$4 x$

$0 \propto 4$

$\geq \sum$

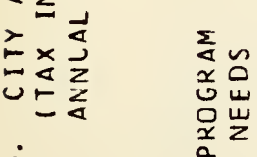

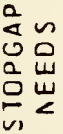

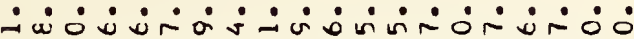

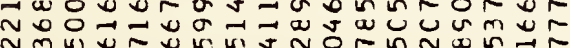

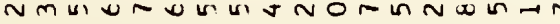

m

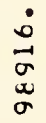

m

$-\dot{0} \dot{0} \dot{0} \dot{0} \dot{0} \dot{0} \dot{0} \dot{0} \dot{0} \dot{0} \dot{0}$

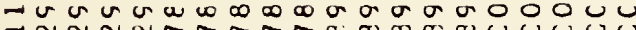

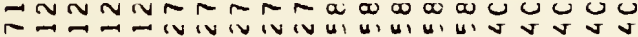

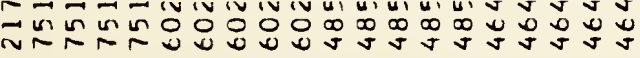

$\stackrel{\dot{v}}{a}$

שุ $\checkmark$

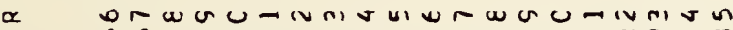

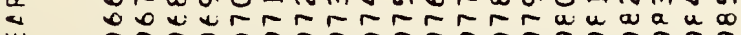

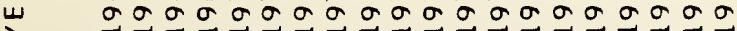




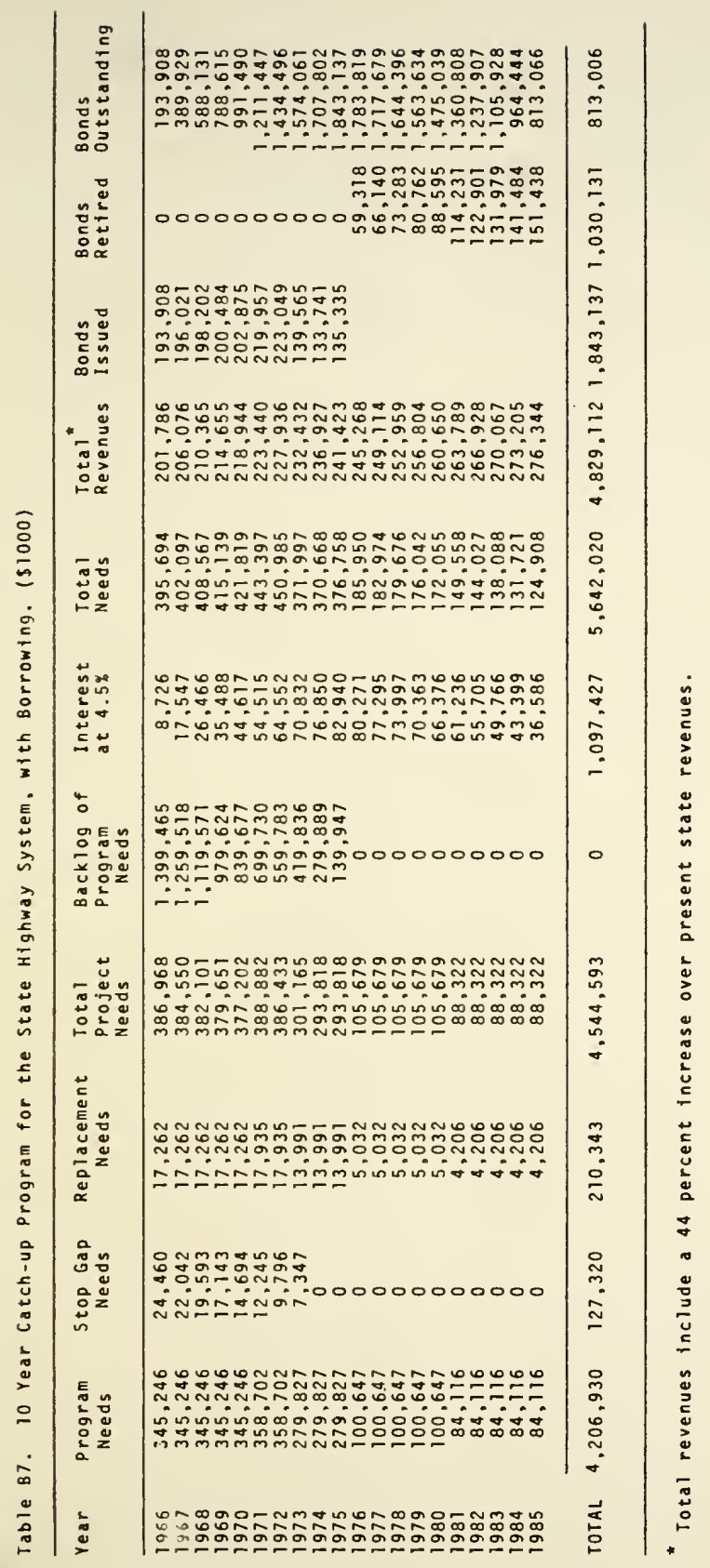



